\title{
Load rating analysis, field testing of steel railroad bridges - dailey branch bridges at mileposts 1.4 and 5.8
}

\author{
Sai Krishna Anudeep Paraitham
}

Follow this and additional works at: https://researchrepository.wvu.edu/etd

\section{Recommended Citation}

Paraitham, Sai Krishna Anudeep, "Load rating analysis, field testing of steel railroad bridges - dailey branch bridges at mileposts 1.4 and 5.8" (2016). Graduate Theses, Dissertations, and Problem Reports. 3984.

https://researchrepository.wvu.edu/etd/3984

This Problem/Project Report is protected by copyright and/or related rights. It has been brought to you by the The Research Repository @WVU with permission from the rights-holder(s). You are free to use this Problem/Project Report in any way that is permitted by the copyright and related rights legislation that applies to your use. For other uses you must obtain permission from the rights-holder(s) directly, unless additional rights are indicated by a Creative Commons license in the record and/ or on the work itself. This Problem/Project Report has been accepted for inclusion in WVU Graduate Theses, Dissertations, and Problem Reports collection by an authorized administrator of The Research Repository @ WVU. For more information, please contact researchrepository@mail.wvu.edu. 


\title{
Load Rating Analysis, Field Testing of Steel Railroad Bridges - Dailey Branch Bridges at Mileposts 1.4 and 5.8
}

\author{
Sai Krishna Anudeep Paraitham
}

Problem report submitted to the Benjamin M. Statler College of Engineering and Mineral Resource

At West Virginia University In partial fulfillment of the requirements

For the degree of

Master of Science

In

Civil Engineering

Approved by

Hota V. S. GangaRao, Ph.D., P.E., Chair

Radhey S. Sharma, Ph.D., Co-Chair

Mark L. Skidmore, M.S., P.E.

Department of Civil and Environmental Engineering

Morgantown, West Virginia

2016

Keywords: Load Rating Analyses, Steel Bridges, Plate Girders, Field Testing, RISA-3D modelling

Copyright 2016 [Sai Krishna Anudeep Paraitham] 


\section{ABSTRACT \\ Load Rating Analysis, Field Testing of Steel Railroad Bridges - Dailey Branch Bridges at Mileposts 1.4 and 5.8}

\section{Sai Krishna Anudeep Paraitham}

In this report, the two steel bridges studied are bridges 1.4 and 5.8 on Dailey Branch line, part of the West Virginia Central Railroad. Bridge at milepost 1.4 is a two span simply supported, through plate girder bridge. The span lengths are 97.042 feet and 95.583 feet. Bridge at milepost 5.8 is a single span simply supported open deck bridge with a span of 17.875 feet. These bridges are evaluated for the load ratings using AREMA 2014 manual using the allowable stress method. Since, the material properties of the bridge members are definitely unknown, the yield strength of steel assumed is in accordance with the instructions in AREMA 2014 manual. The two steel bridges referred to in this report were load rated using Cooper E 80, 286k railcar, GP 38, and GP 9 locomotives. WVU-CFC has performed the visual inspection in May 2014 on the bridges for general condition assessment and measuring section loss. The visual inspection revealed negligible section loss on the interior bottom angles, towards the north-west of girder two, just above the bearings. Hence, for the evaluation of load ratings, the reduction in dimensions are not taken into account. The bridge members including girders, floor beams, and stringers are analyzed for maximum bending moments and shears using RISA (Structural Analysis) software, in conjunction with MS-EXCEL calculations for load rating.

The field-testing performed in August 2014, on these two bridges at mileposts 1.4 and 5.8, measuring deflections, strains including flexural compression, flexural tension and shear strains for girders, floor beams and stringers. During field-testing, WM 82 locomotive and hi-rail dump truck were used as live loads, moving at crawling speed, across both bridges. Field-testing results obtained for main girders of bridge 1.4 were in the range of 5\% to $12 \%$ lower than the analytical results in the case of the hi-rail dump truck and $7 \%$ to $10 \%$ lower than the analytical results in the case of the locomotive. The floor-beam shear strains measured in the field are $50 \%$ to $88 \%$ lower than the analytical results. The difference between the floor beam shear strains may be due to the software limitations and assumptions while modeling the end conditions of floor beams. For stringers, field testing results for flexural strain were $63 \%$ lower than the analytical strains for the hi-rail dump truck load, 12\% lower than the analytical result for the locomotive. For bridge 5.8, the field test results for flexural strains were $48 \%$ to $57 \%$ and shear strains $41 \%$ to $63 \%$ lower than analytical strain. Such discrepancy may be due to the contribution from the track structure not being accounted for in the analytical model. The scope of rehabilitation of the bridge embankments are also discussed in the report. There is no evidence of any settlements and disruption of embankments, however, gaps were observed between track and subgrade indicating draining out of ballast due to loosened surface material. Regular inspection for track and embankment stability were recommended at both the bridge sites. Further, building timber walls to prevent sliding of ballast is recommended to stabilize embankment and to prevent major maintenance issues. Based on field inspection, load rating analysis, and field testing, it has been found that bridges 1.4 and 5.8 can safely carry rolling stock equipment including, 286k railcar, GP 38, GP 9 and WM 82 locomotives, at $10 \mathrm{mph}$ speed. Also, it has been concluded that the two steel bridges did not need any structural rehabilitation. 


\section{ACKNOWLEDGEMENTS}

It gives me extreme happiness to place on record my heartfelt and profound gratitude to Dr. Hota V. S. Gangarao, for his valuable guidance, sustained encouragement and inspiration throughout my work. He was my supervisor, mentor, and well-wisher and in fact, he meant everything to me. He has taught me very useful things in life, and I cherish the memories of every moment that I spent with him, throughout my life.

I profusely thank Mr. Mark Skidmore for sharing his abundant practical knowledge and for actively participating in the discussions with me on the subject. His immense patience and a keen interest in the subject discussion were the key factors that helped me shape my work to the present form.

My sincere and deeply felt thanks to Dr. Radhey Sharma, for his unstinting support and continuous encouragement. His affectionate touch has always instilled positive spirit in me and made me feel confident in the hours of criticality.

Finally, I thank my parents, family members, friends, near and dear and all well-wishers, who have prayed and wished for my success in my educational endeavors.

- Sai Krishna Anudeep Paraitham 


\section{TABLE OF CONTENTS}

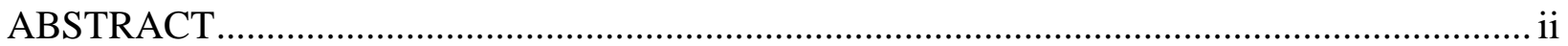

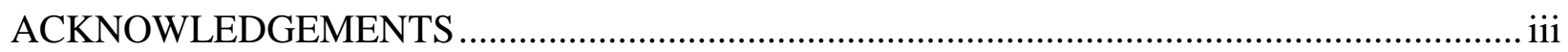

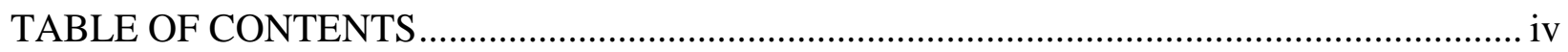

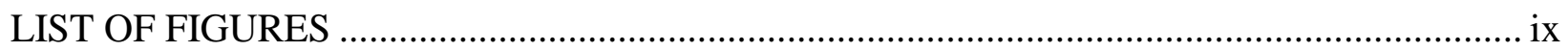

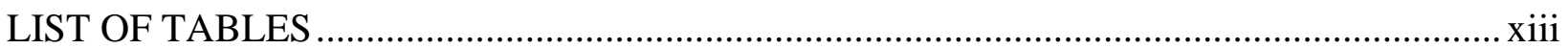

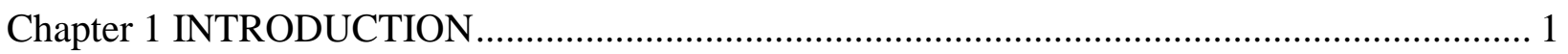

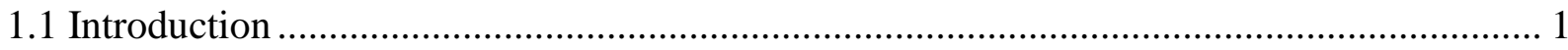

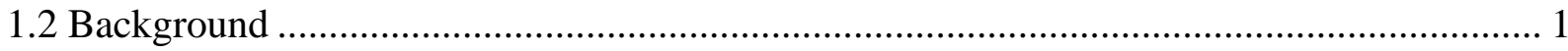

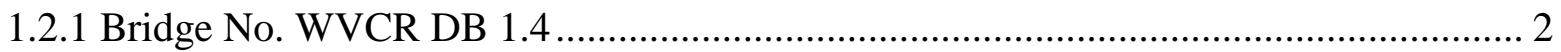

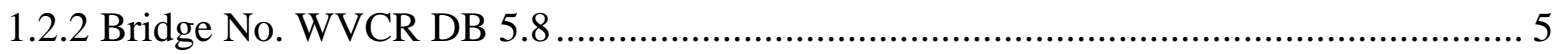

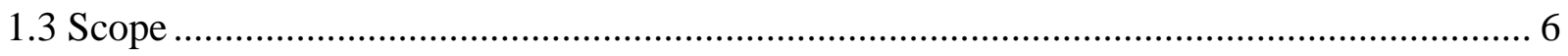

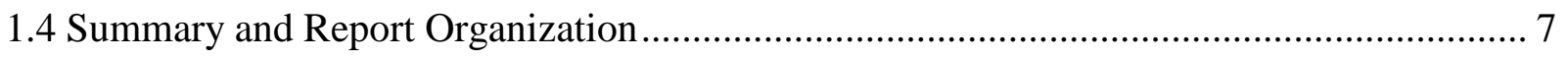

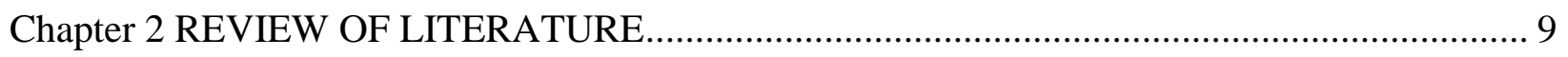

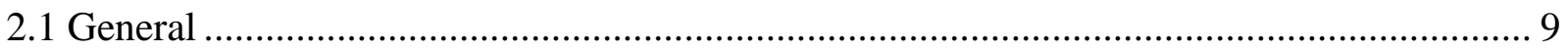

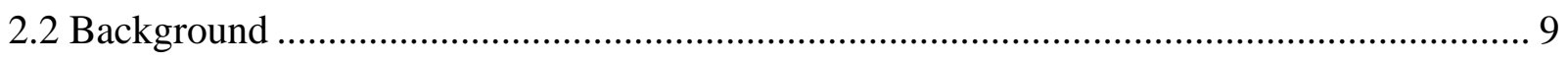

2.2.1 Steel Plate Girder Bridges ........................................................................... 9

2.2.2 Fracture Critical Members - FCM ............................................................ 10

2.2.3 AREMA Manual, Guidelines for Load Rating................................................. 11

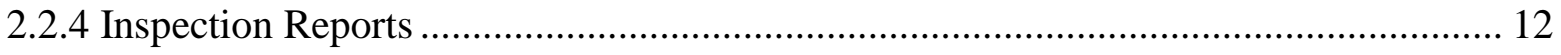

2.3 Field Testing and Condition Assessment ......................................................... 12 


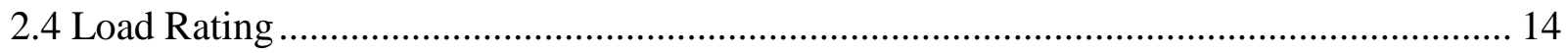

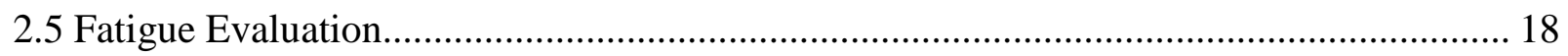

2.6 Rehabilitation / Retrofitting of Steel Railway Bridges ................................................... 19

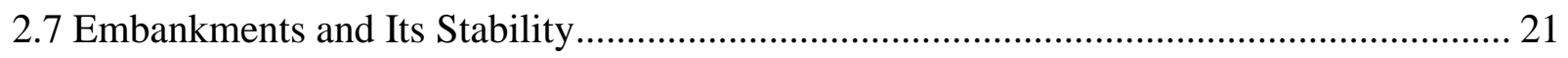

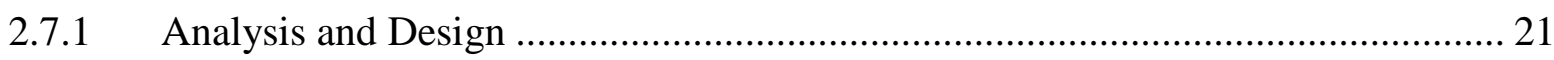

2.7.2 Damage and Failure Patterns ………………….................................................... 22

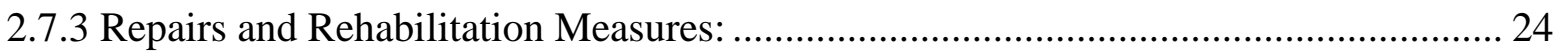

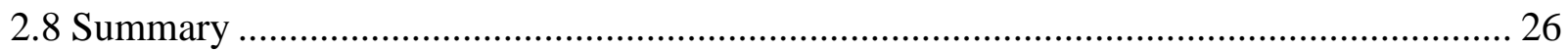

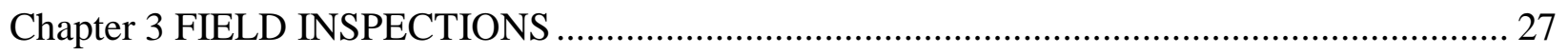

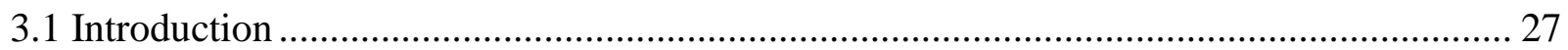

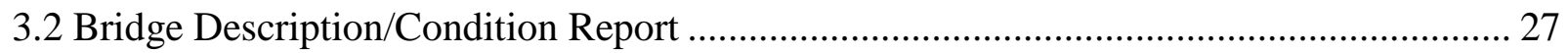

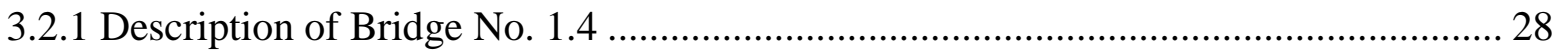

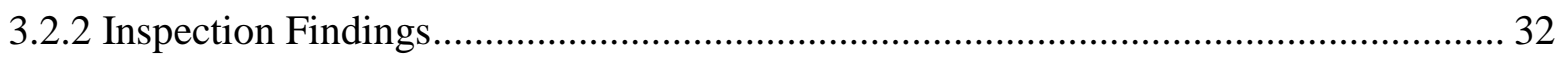

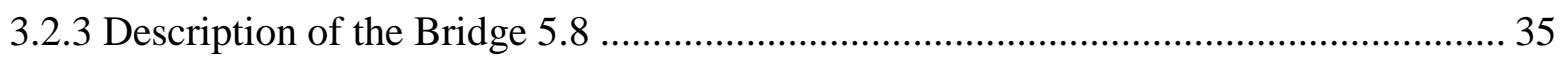

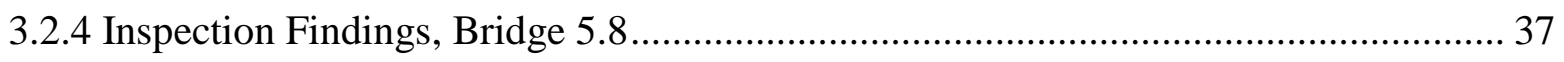

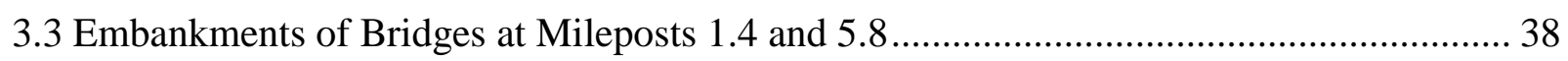

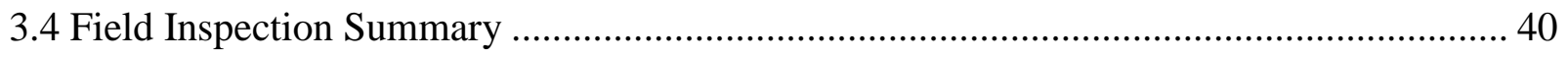

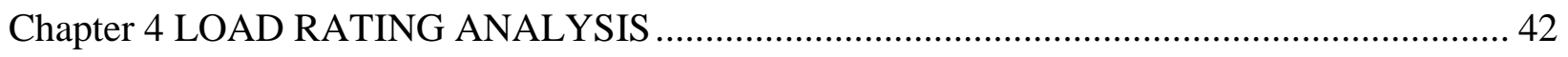

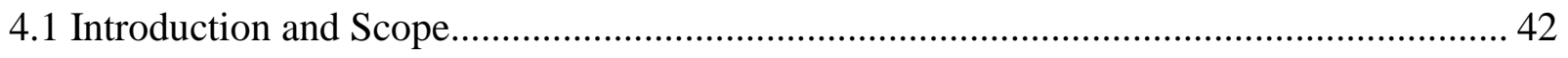

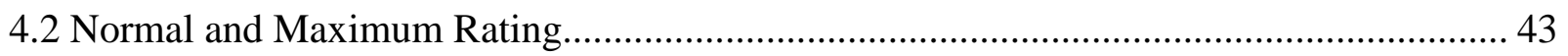

4.2.1 Allowable Stresses - Normal Rating ......................................................................... 44 


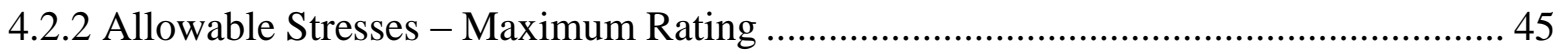

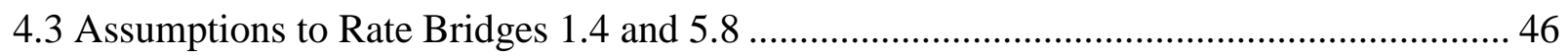

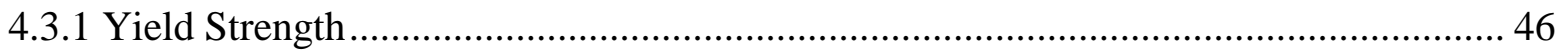

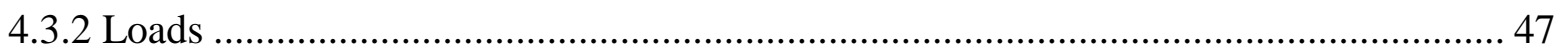

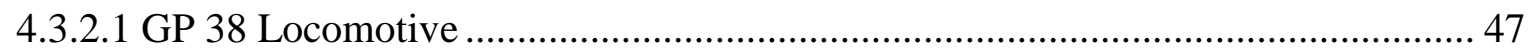

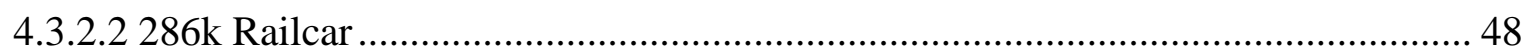

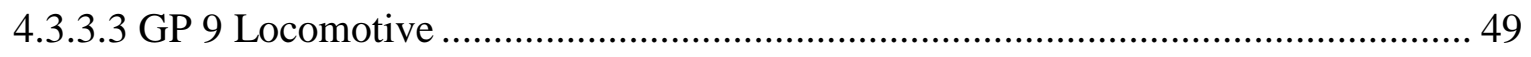

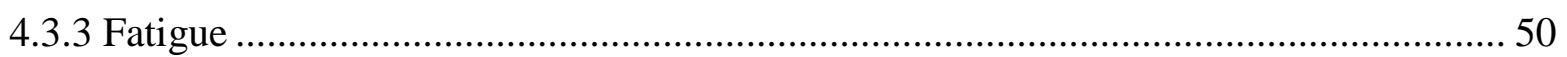

4.3 Structural Analysis, Load Ratings and Software Tools .................................................... 50

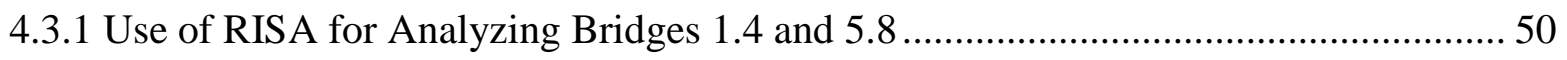

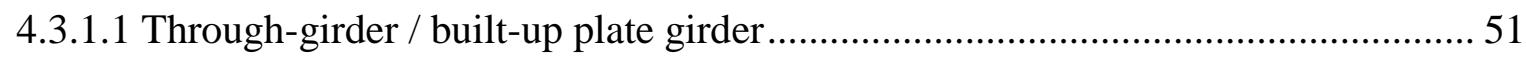

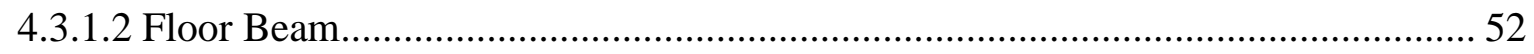

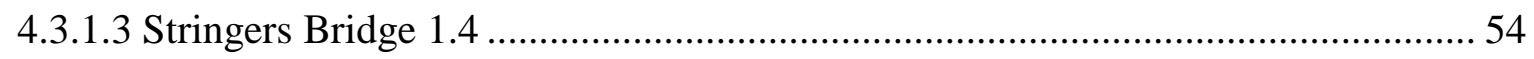

4.3.1.4 Bridge 5.8 Girders................................................................................ 55

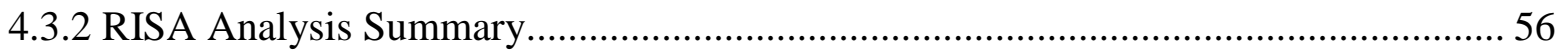

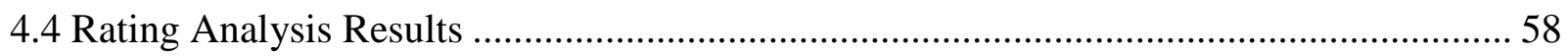

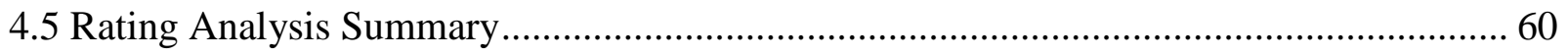

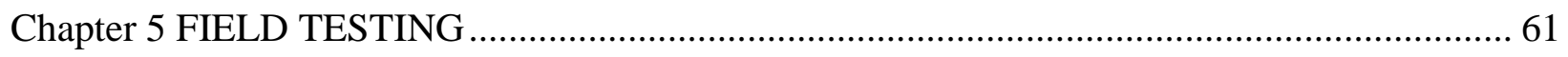

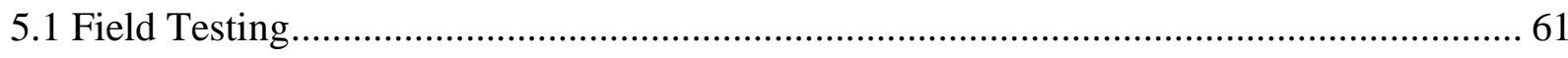

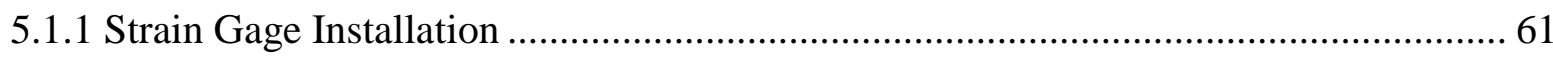

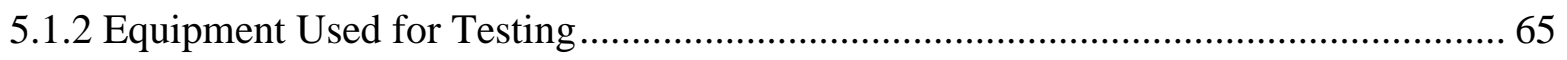

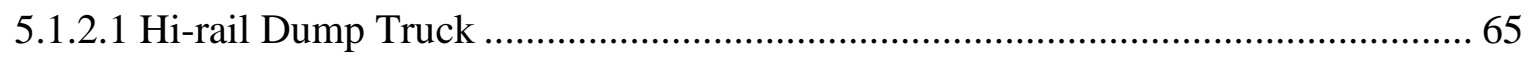




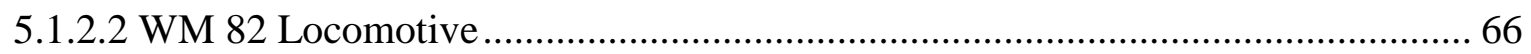

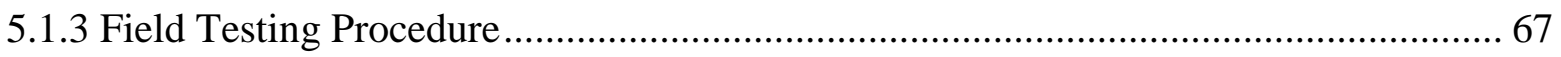

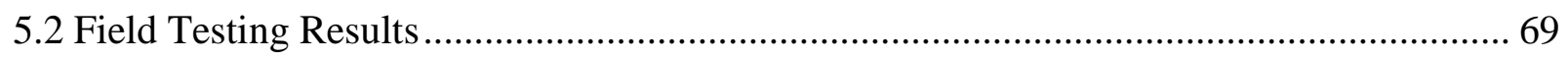

5.2.1 Bridge 1.4 and 5.8 Bending and Shear Strains (Truck) ........................................... 70

5.2.2 Bridge 1.4 - Bending and Shear Strains (Locomotive) …………………………….... 72

5.2.3 Compression (Explained by Strain Response) …………………………………….... 73

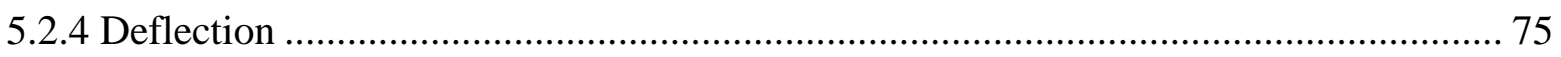

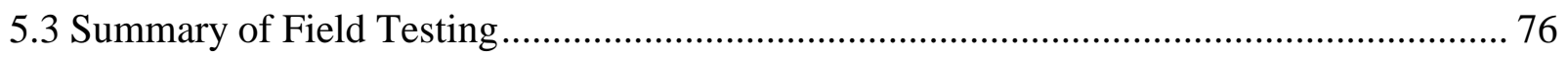

Chapter 6 CONCLUSIONS AND RECOMMENDATIONS ..................................................... 78

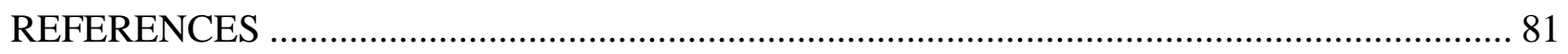

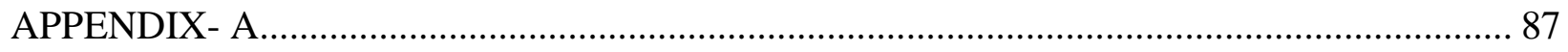

LOAD RATING ANALYSIS - THROUGH GIRDER ……………………………............. 88

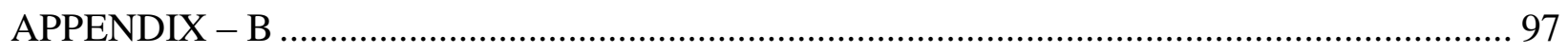

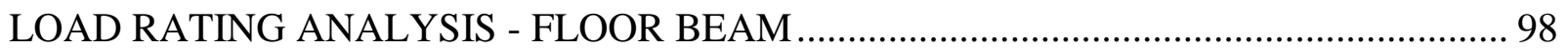

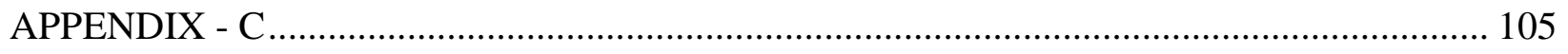

LOAD RATING ANALYSIS - STRINGER (Bridge 1.4) ................................................. 106

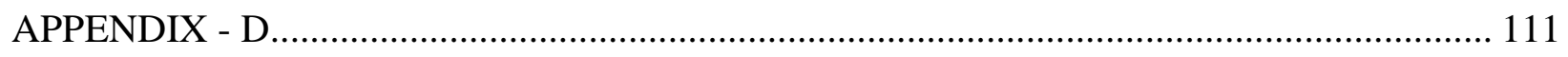

LOAD RATING ANALYSIS - GIRDER (Bridge 5.8) …………...................................... 112

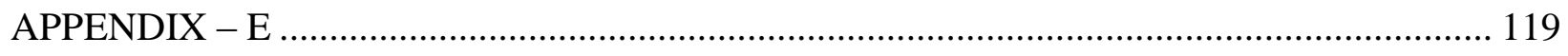

STRAIN CALULATIONS (Hi-Rail Dump Truck and WM 82).......................................... 120

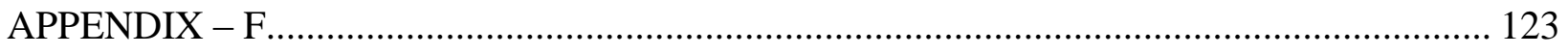


INSPECTION CHARTS - Bridge 1.4 and Bridge 5.8. . 


\section{LIST OF FIGURES}

Figure 1- Locations of the Bridges 1.4 and 5.8 (Source: Google Maps, http://maps.google.com) 3

Figure 2- Location of Railroad Bridge 1.4 (Source: Google Maps, http://maps.google.com) ....... 4

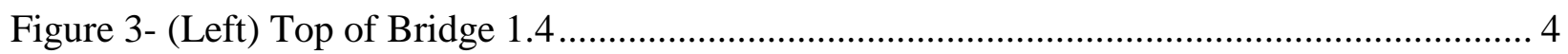

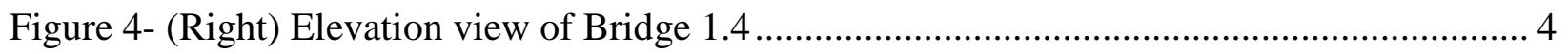

Figure 5- Location of Railroad Bridge 5.8 Across the Dodson Run (Source: Google Maps,

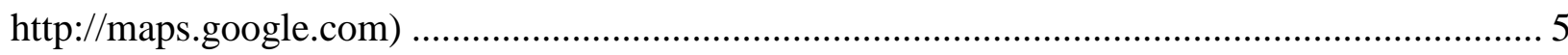

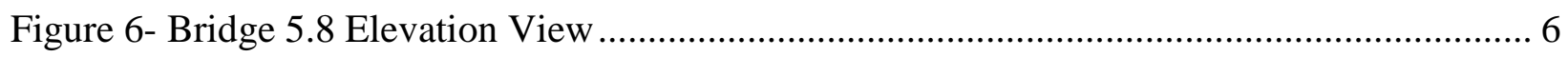

Figure 7- Cooper E 80 Loading, Maximum axle load 80 kips (Adopted from AREMA 2014

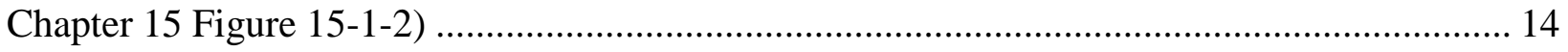

Figure 8- Destruction of Embankment Around a Culvert Due to Damming of Water on the Upstream Side of the Railway Line Between Oslo to Bergen in Norway (Heyerdahl H et.al, 2013) 23

Figure 9- Total Destruction of Embankment Around a Culvert Due to Damming of Water on the Upstream Side of the Railway Line Between Oslo to Bergen in Norway (Heyerdahl H et.al, 2013)

Figure 10- Derailment Caused by Failure of an Embankment Due to Scour During a Cyclone

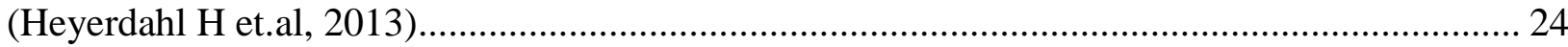

Figure 11- Raising the Track and Insertion of the New Formation Protective Layer Using AHM

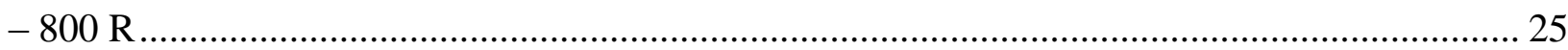

Figure 12- Typical Geo Pier System Supporting the Embankment (Lien and Fox, 2001)........... 25

Figure 13- Segmental Rocker Bearing on Abutment 1............................................................ 29

Figure 14- Dimensions (inches) of Plate Girder at Mid Span, Floor Beam, and Stringer of Bridge 1.4 
Figure 15- Top View of Bridge 1.4 From North End.

Figure 16- Bottom View of Bridge 1.4 - Marked are floor beams (horizontal line), stringers (dotted lines) and cross bracings (cross lines).

Figure 17- Side View of Bridge 1.4 (North indicated by arrow) .......................................... 31

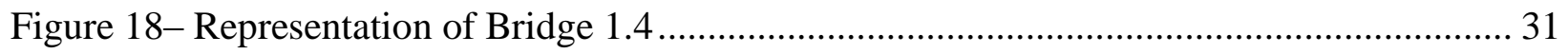

Figure 19- Severe Corrosion Activity Seen on the Interior Bottom Angle of Girder 2 at the North-West End 32

Figure 20- Bottom of the Stiffener of Girder 2 (Span 1, Center) with 100\% Section Loss. 33

Figure 21 - Web Crippling at The Bottom of the Web Due to Loss of Section of The Bearing Stiffener, (Khurram, 2014). 34

Figure 22- (Top) Side View of The Superstructure from Northwest Direction. (Bottom Left) Bottom View of Superstructure - Marked are Vertical Cross Frame/ Diaphragm (Cross Lines), and Horizontal Cross Bracings. (Bottom Right) Top View of the Bridge at Milepost 1.4 (North Side of the Bridge is Towards the Bottom of The Picture) .................................................... 36

Figure 23- Bent Interior Bottom Flange of Girder 1............................................................ 37

Figure 24- (Left) Gap Between the Tracks and Sub Grade of Bridge No. 1.4 Approach Embankment. (Right) Vegetation is Seen on Slope of the Embankment of Bridge No. 1.4....... 39

Figure 25- Approach Embankment of Bridge No. 5.8, Vegetation can be Seen on the Embankments and on The Area Between the Rails. 39

Figure 26- Axle Spacing and Axle Weights of GP-38 Locomotive (Adopted from The Diesel Shop, 2016) 48

Figure 27- 286k Railcar Axle Spacing and Axle Weights..... 48

Figure 28- GP-9 Locomotive Axle Spacing and Axle Weights 49 
Figure 29- Through Girder or Built-up Plate Girder (Field Representation With Cover Plates,

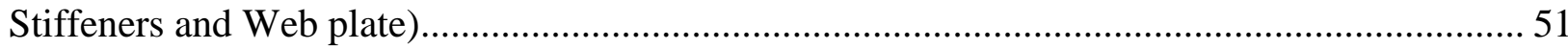

Figure 30- Through Girder Designed in RISA, as a Beam With Thick flanges and Web and Pinned-Pinned Boundary Condition. Live Load - Cooper E 80, Live Load Moment - 6060.3

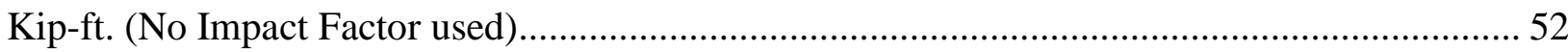

Figure 31- Shape Properties, Floor Beam ......................................................................... 53

Figure 32- Rendered Model Consisting of Floor Beam, Stringers and Girders With Load Passing Over The Bridge Model Obtaining a Maximum Bending Moment of $403.5 \mathrm{ft}$-kips (No Impact Factor Used) for Floor Beam (Circle) and 128.8 ft-kips (No Impact Factor Used) For Stringer (Rectangle)

Figure 33- Rendered Model Consisting of Floor Beam, Stringers and Girders With Load Passing Over The Bridge Model Obtaining a Maximum Shear of 99.8 ft.-kips Floor Beam (circle) and

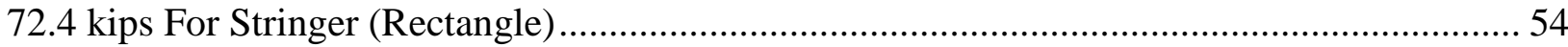

Figure 34- Shape Properties of Stringer of Bridge No. 1.4 Used in RISA ............................... 55

Figure 35- Showing Rendered Model of Girder of Bridge No. 5.8 in RISA With Cooper E 80Wheel Load Moving Over The Stringer to Get a Maximum Bending Moment and Shear......... 56

Figure 36- Shape Properties of The Section Built-up in RISA For The Analysis, Obtaining a

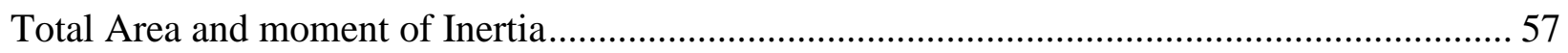

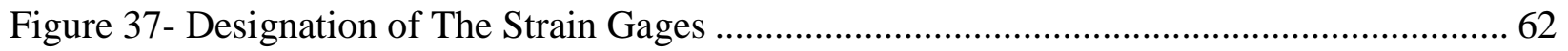

Figure 38- AUTOCAD- 3D Drawing Showing the Location of The Strain Gages on Bridge No. 1.4 .

Figure 39- Bottom View of The Bridge No. 1.4 (Span 1), Showing Location of strain Gages on Floor Beam and Stringer. 64

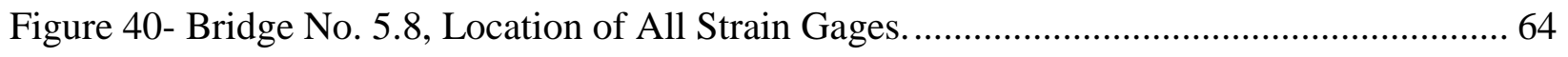

Figure 41 Schematic Representation of Hi-rail Dump Truck ............................................. 65 
Figure 42 Axle spacing and Axle Weights of Hi-rail Dump Truck....................................... 66

Figure 43 Axle spacing and Axle Weights of WM 82 (BL-2) Locomotive .............................. 67

Figure 44- Plot of Bending Strain vs Time of Girder 1 of Bridge 5.8, The Peak Stain is Located

Between the Rear Hi-rail Axle and Rear Axle................................................................... 68

Figure 45- RISA 3D Model of Bridge No. 1.4, Used for Analysis of Maximum Shear and

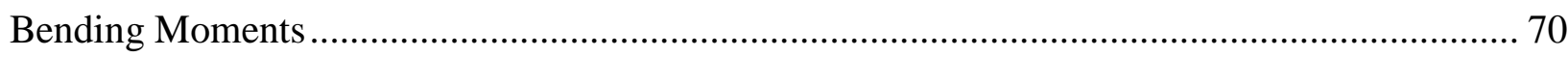

Figure 46- Location of Gages Fixed on Interior and Exterior Vertical Legs of Bottom Angles. 74 


\section{LIST OF TABLES}

Table 1 Allowable Stresses for Rating (Excerpt from AREMA 2014 Table 15-1-11) .............................15

Table 2-Allowable stresses for Normal and Maximum Rating ........................................................... 44

Table 3-Calculated Allowable Stresses for Rating for Normal Rating ................................................. 45

Table 4-Calculated Allowable Stresses Maximum Rating .................................................................. 45

Table 5- Table Showing Distances Between Floor Beams in Span 1, Bridge 1.4 .................................. 55

Table 6-Summary of Maximum Bending Moment and Shear Forces For Bridge 1.4 …........................58

Table 7-Summary of Maximum Bending Moment and Shear Forces For Bridge 5.8 …......................... 58

Table 8-Load Rating Results of Bridge 1.4 Members ................................................................... 59

Table 9-Load Rating Results of Bridge 5.8 Members ..................................................................... 59

Table 10- Number of Strain Gages per Bridge with Designated Locations (Gages No. 5 and 13 of Bridge

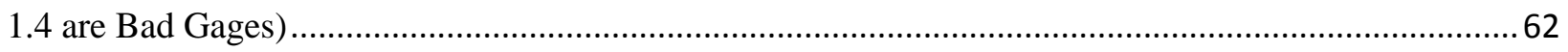

Table 11- Strain Gage Readings of The Field Test Conducted With The Hi rail Dump Truck on Bridges

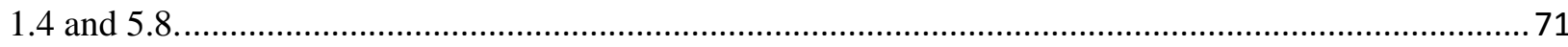

Table 12- Comparison of Strain Gage Readings of the Field Test Strains (WM 82 Locomotive on Bridge

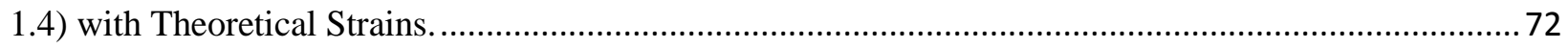

Table 13- Ratios of Average Field Micro Strain Values Obtained From Train and Truck. ......................73

Table 14- Ratios of Theoretical Micro Strain Values Obtained From Train and Truck...........................73

Table 15- Measured Strains During Field Testing, Strain Gages Fixed to The Interior and Exterior Vertical Legs of Bottom Angles at Northwest End of girder 2 ......................................................... 74

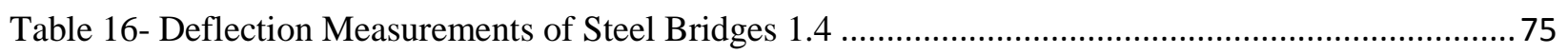

Table 17- List of the Required geotechnical Engineering analyses for Embankments (US-DOT, 1988). 


\section{Chapter 1 \\ INTRODUCTION}

\subsection{Introduction}

Many in-service railroad bridges, are deteriorating due to physical and chemical aging or excess deformations due to increased live loads, increased load frequencies and aging related issues. Bridges, to be functional with the increased loads, need inspections at frequent intervals. If the inspection reports reveal deterioration that effects the safe functioning of the bridge, the safe load carrying capacity of the bridge would need evaluated via load rating analysis. This may require the bridge to rehabilitated or replaced. Hence, inspection, evaluation and rehabilitation of older bridges are important and specific tasks to determine the safety and functionality of a bridge and must be carried out in a systematic and scientific manner (Bacinskasa et al. 2013).

This report focuses on the inspection, rating and field testing of Bridges 1.4 and 5.8 of Dailey Branch based on their current condition, including the embankments. A brief discussion in Sections 1.2 and 1.3 is provided on background, and scope of the report in general.

\subsection{Background}

Dailey Branch is a part of West Virginia Central Railroad short line system, which is located in Randolph and Barbour Counties. It is an approximately 10-mile section that runs out of Elkins, WV, with rail tracks ending in Dailey, WV. The line was previously owned by CSX Corporation, and is currently owned by West Virginia Department of Transportation - State Rail Authority (WVDOT-SRA) and is considered part of West Virginia Central Railroad (WVCR). WVCR operations started May 16, 1998, and has an interchange with the Appalachian and Ohio 
Railroad. Currently, the Durbin \& Greenbrier Valley Railroad manages the train operations and undertakes maintenance activities for WVCR (WVDOT, 2016 and WV Statewide Rail Plan, 2013).

The WVDOT-SRA contracted with the West Virginia University - Constructed Facilities Center (WVU-CFC) to evaluate five of the bridge structures between Elkins and Beverly, WV, approximately a roughly 5-mile section. The purpose of this evaluation was to determine the applicability of using Fiber Reinforced Polymer (FRP) composite materials to repair and strengthen the bridges and allow the line to be reopened. This report concentrates on two steel structures located between Elkins and Beverly, WV at mileposts 1.4 and 5.8 (Figure 1). The remaining three timber bridges were analyzed and evaluated separately.

\subsubsection{Bridge No. WVCR DB 1.4}

WVCR DB Bridge 1.4 is located 1.4 miles south of Elkins Junction and consists of two simple spans of lengths 97.042 feet and 95.583 feet (both center to center of bearings). Each span consists of a through plate girders, floor beams and stringers. The main girders constitute a builtup section including flange angles, cover plates, and web plates. Floor beams and stringers are comprised of rolled sections. This bridge also carries ties, tie spacers, tie anchors, anchor plates, stringers, floor beams, and a wooden walkway. Figure 2 shows the location of the bridge, and Figure 3 and Figure 4 show top and elevation views of Bridge 1.4. All members are riveted indicating the bridge was likely built before 1960, but the actual construction date is unknown. More information for the bridge is presented in Chapter 4, along with inspection information. 


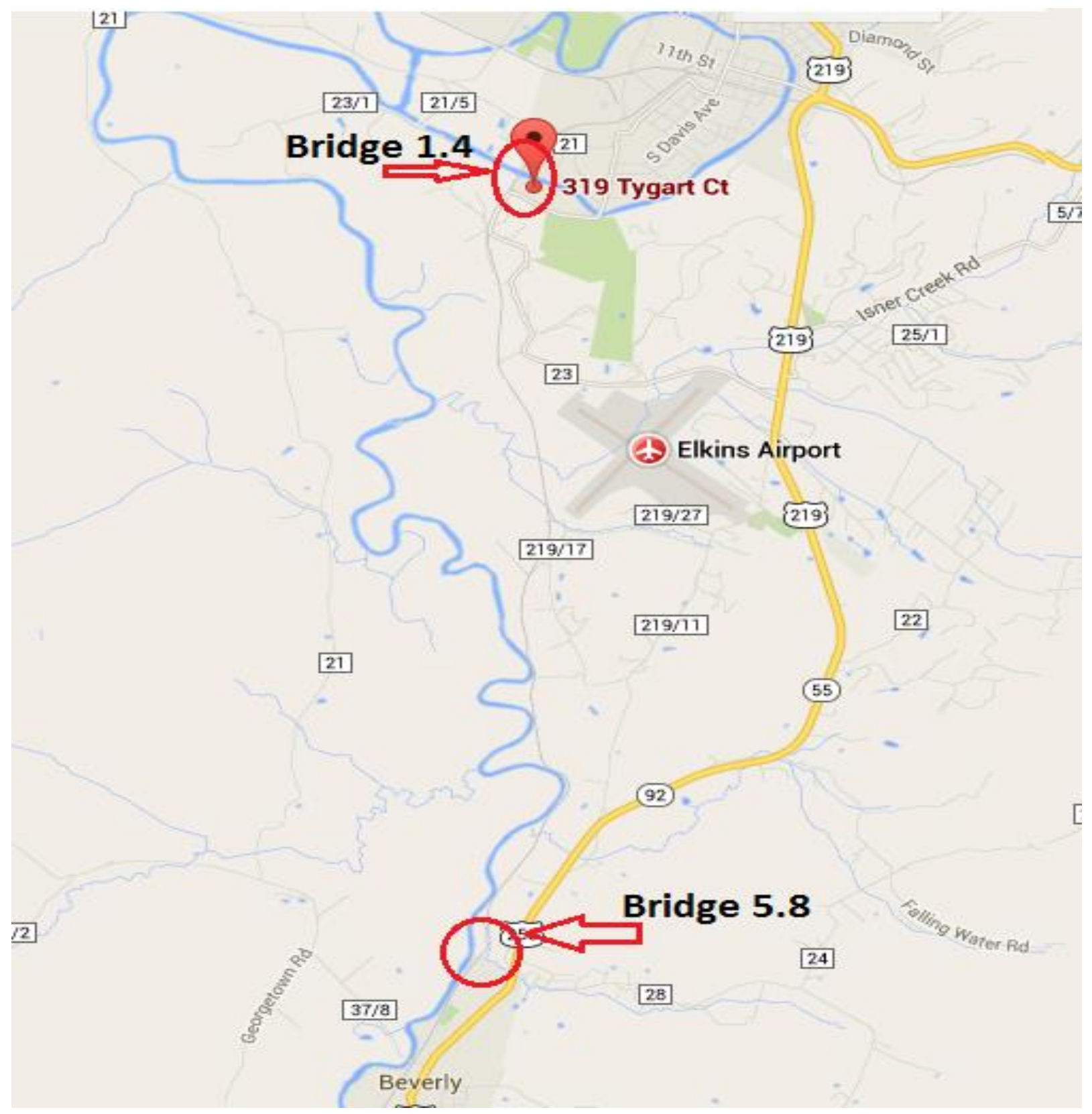

Figure 1- Locations of the Bridges 1.4 and 5.8 (Source: Google Maps, http://maps.google.com) 


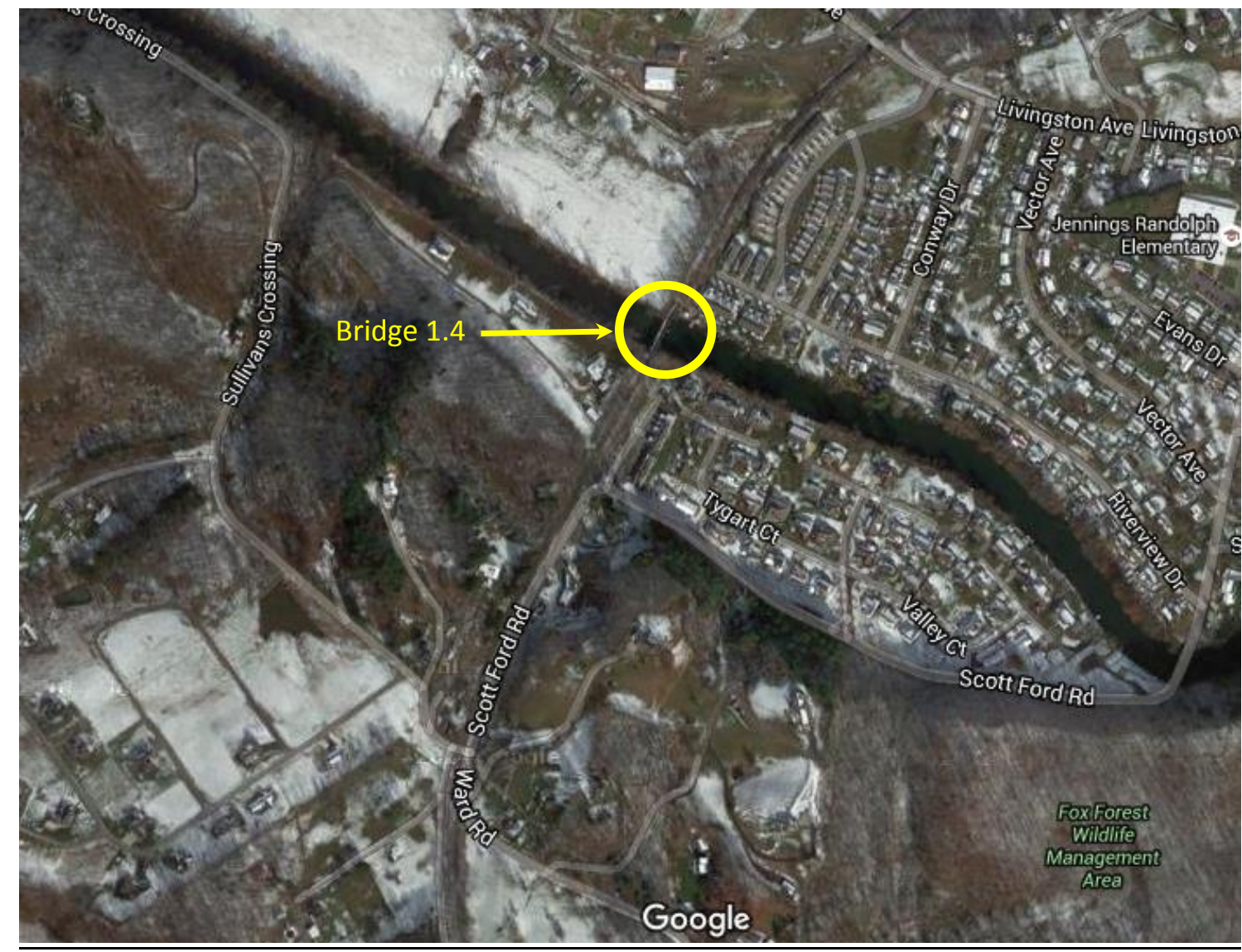

Figure 2- Location of Railroad Bridge 1.4 (Source: Google Maps, http://maps.google.com)
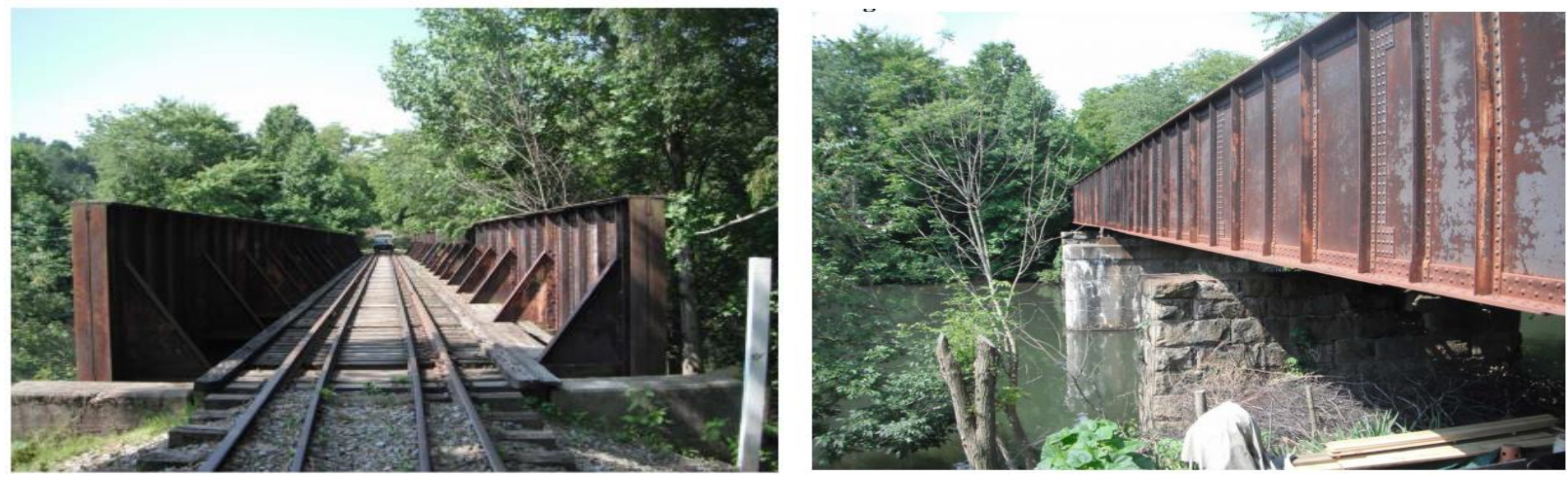

Figure 3- (Left) Top of Bridge 1.4

Figure 4- (Right) Elevation view of Bridge 1.4 


\subsubsection{Bridge No. WVCR DB 5.8}

WVCR DB Bridge 5.8 is located 5.8 miles south of Elkins across Dodson Run. The bridge is a single simple span 17.875 feet long deck girder type with two steel built-up plate girders, each 30.5 inches deep and composed of web plate and flange angles, and transverse stiffeners riveted to the web of the girder, vertical stiffeners welded and riveted to girder plates and cross frames. Figure 5 and Figure 6 show the approximate location and an elevation view of the bridge, respectively. The abutments and wing walls of the bridge are made up of stone masonry.

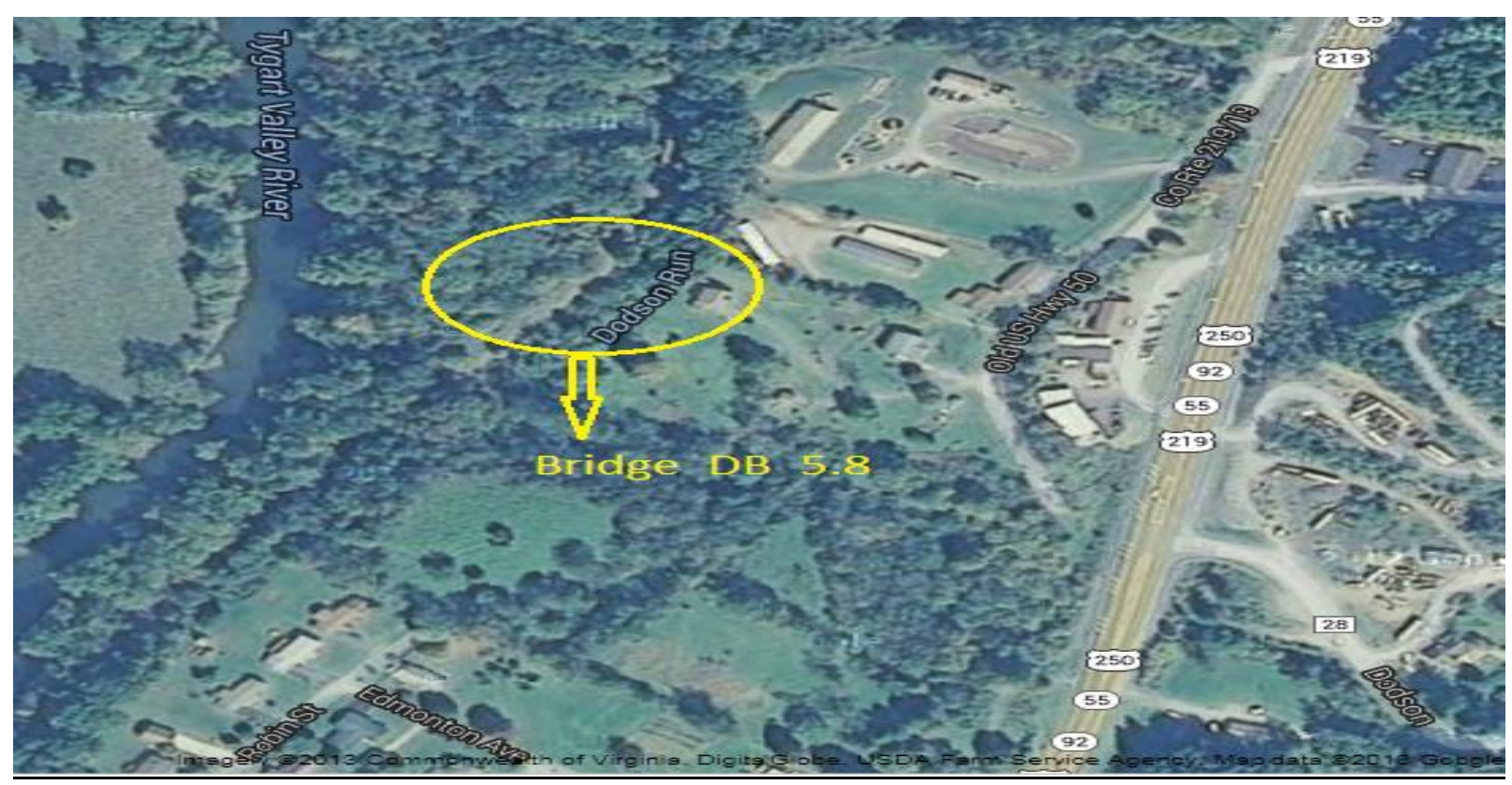

Figure 5- Location of Railroad Bridge 5.8 Across the Dodson Run (Source: Google Maps, http://maps.google.com) 


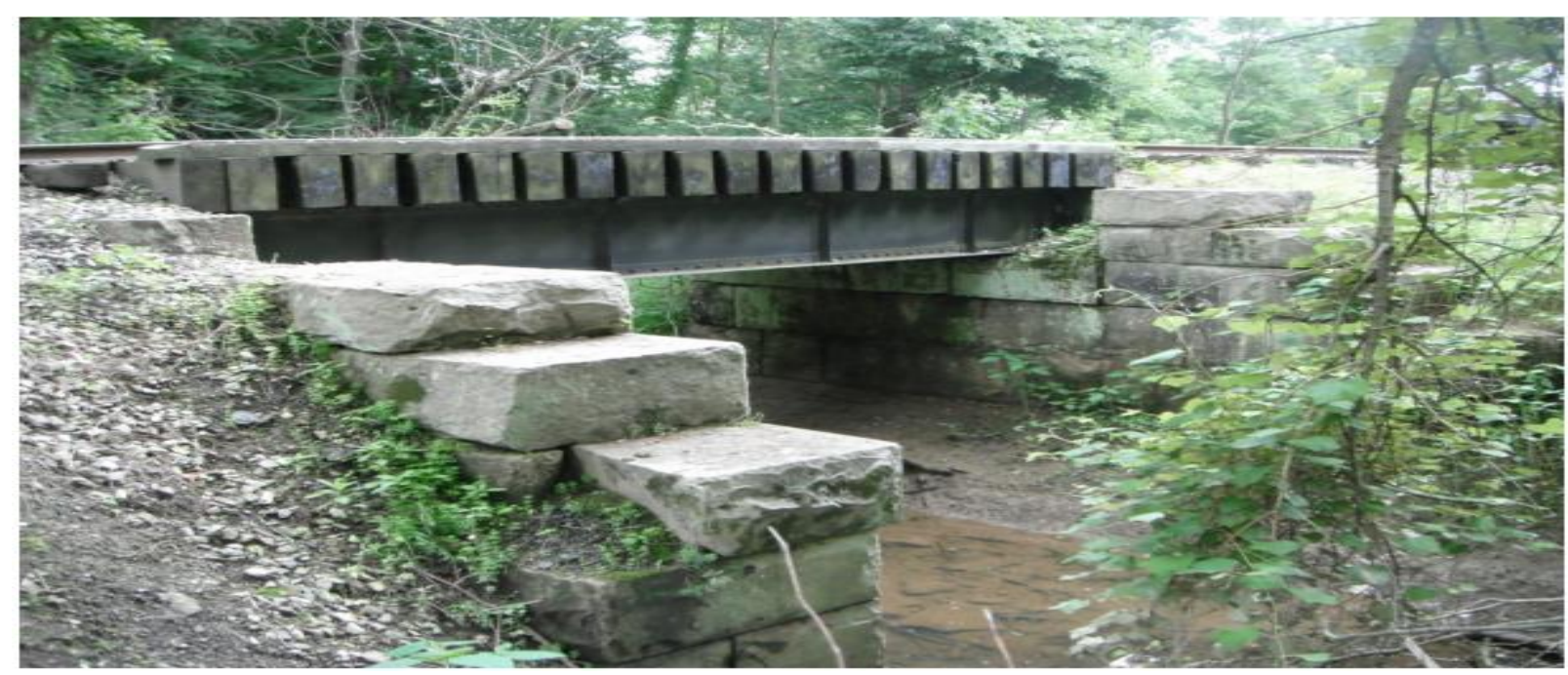

Figure 6- Bridge 5.8 Elevation View

\subsection{Scope}

The scope of the report is a collection of field data, evaluate the load rating with the available data and later a field testing is conducted wherein the results obtained from field testing are compared to the analytical results. As a part of the collection of field data, field investigations included the visits to the site, visual inspection of the bridges and their components for their condition assessment. Details of field investigations are presented in Chapter 3. Field inspections were conducted on the two steel bridges 1.4 and 5.8 by WVU-CFC. Field inspection and testing were performed in May 2014. After field inspection, data used was verified and updated accordingly to determine the rating. The intent of load ratings for the two bridges (DB 1.4 and 5.8) in this report is to evaluate the safe live load carrying capacity of these bridges. The load ratings in this report are based on the AREMA 2014 manual utilizing allowable stress method. As a part of the inspection cycle, bridge load ratings were evaluated in 2014 by WVU-CFC. Three design loads namely Cooper-E loading, GP 38 and 286k railcar were used for the load rating analysis and their details are given in Sections 4.3.2. The live load for the load rating 
analysis shall be one of the Cooper E series or load specific equipment according to AREMA Chapter 15, Section 7.3.2.2. The 286k railcar and the GP 38 locomotive loads were placed on the bridge at a critical location to establish bridge ratings, similar to the Cooper E load and an equivalent Cooper E load rating was generated. Since the GP 9 is currently used on the rail line, WVU-CFC has conducted load rating analysis for GP 9. However, ready availability of WM 82 locomotive and a dump truck on hi-rails enabled us to use those two (locomotive and dump truck) these were utilized for the load testing and are discussed in Chapter 5. Field tests included the identification of the locations for deflection and strain measurements, loading of the two bridges with WM 82 Locomotive and hi-rail dump truck. Field test results and comparison with analytical results for equipment WM 82 and hi-rail dump truck are also discussed in Chapter 5.

The scope the project also includes a review about the embankments of the Bridges 1.4 and 5.8. In this report, a brief literature review on the investigation, analysis of embankment stability and failure types of embankments is carried out along with rehabilitation recommendations. Field inspection included visual inspection of bridge approaches and embankments behind the abutments. Further in Chapter 4, the embankments of the bridges at mileposts 1.4 and 5.8 are discussed by comparing the review failure patterns documented in Chapter 2, Section 2.7 and the identifications from field inspections by WVU-CFC.

\subsection{Summary and Report Organization}

Chapter 2 presents discussions and finding of literature review concerning the steel bridges, railroad bridges, load rating. Chapter 3 explains the field inspection methodologies and findings. Chapter 4 describes load rating analyses including assumptions and procedures followed. A limited study is also conducted to arrive at limiting section loss for the bridge rating. Ratings 
calculated are compared with Baker report. Chapter 5 presents the field testing results and a comparison of field testing and analytical results. Detailed calculations for load rating analyses and inspection charts are included in Appendices A through F. 


\section{Chapter 2 \\ REVIEW OF LITERATURE}

\subsection{General}

Research has been conducted into various aspects related to railroad bridges, such as their analysis, design, modelling and behavior under static and dynamic loads, fatigue behavior, etc. Before the load rating analyses and field testing of the two old steel bridges under consideration, it is felt that a knowledge of past works done on the related topics will be very much useful in determining a methodology for our work. Hence a detailed review of literature is done focusing on aspects such as load rating and field testing methods, standards and manuals available, identifying the fracture critical members, condition assessment of the bridges with particular reference to fatigue. The safety aspects of the embankments of the bridges and the retrofitting aspects of steel railway bridges are also discussed. An attempt is made to organize the various works and their findings, comment on the outcome of the review wherever possible and concluding on the entire review.

\subsection{Background}

\subsubsection{Steel Plate Girder Bridges}

Small railroad bridges started using plate girder spans as early as 1847 (McVarish, 2016). In 1889, Theodore Cooper noted "the use of plate girders for spans up to $65 \mathrm{ft}$. " (McVarish, 2016). By 1930, the spans were built up to $150 \mathrm{ft}$. After advancement of steel making process, many steel bridges were constructed in the last century, particularly small span structures, across the United States. Rolled steel I-beam girders are commonly used for short to moderate spans of 
steel railway bridges. When a rolled I-beam section is insufficient, a built-up plate girder is usually employed to satisfy the strength and serviceability requirements. Several investigative works (analytical and experimental) were taken up by researchers to understand the behavior and evolve suitable sections of plate girders for different practical conditions and loading situations. (Hasan, 2015) presented a review of numerous such works on straight steel and steel - concrete composite plate girder bridges and summarized the outcomes of those works. The classification of plate girders was made based on web panel status (stiffened webs, corrugated webs, and webs with openings) and type of applied load (shear, patch, fatigue, bending moment or a combination of them) and works were reviewed and reported accordingly.

A report of the American Society of Civil Engineers (ASCE, 2009) says that about $26 \%$ of the bridges in the United States are either structurally deficient or functionally obsolete, which is quite indicative of the need to inspect, assess the condition and apply maintenance or retrofitting on a priority basis. Various studies related to damages and/or failures of steel bridges along with the responsible factors are reviewed and presented in the following sections.

\subsubsection{Fracture Critical Members - FCM}

It was reported in a study that the environmental factors and changing loads influence the structural conditions of bridges (Aflatooni, 2015). All the members of a structure are at risk of developing flaws due to environmental factors or loads. When it comes to fracture critical members, even a minute flaw due to the influence of environmental factors may lead to collapse of the bridge. AREMA defines fracture critical members as "those members or tension components of members whose failure would be expected to result in collapse of the bridge or inability of the bridge to perform its design function" (AREMA, 2014). 
Dexter (2005) presented a paper on findings of NCHRP Sysnthesis Project 35-08 which gives information about the design, fabrication, inspection and classification of fracture critical bridges and FCM's. As mentioned by Potter (2016) that in the US $11 \%$ of the bridges are classified as fracture critical and of that $11 \%, 75 \%$ were built prior to 1970 's. The term fracture critical according to Potter was coined in the late 1960's after the collapse of the Silver Bridge. Another collapse of the Mianus River Bridge due to a fatigue crack caused by corossion on a fracture critical member lead to more research. The author summarizes that since 1970's, inspections procedures are much stricter and provisions were developed for FCM and implemented so that fatigue induced fracture are rare in bridges.

\subsubsection{AREMA Manual, Guidelines for Load Rating}

The AREMA manual is "the base document for railroad bridge design, construction and inspection were formed by private railroads joining their effort" (Sorgenfrei, 2000). The AREMA manual has certain provisions for the geometrics, primary bridge loading, and locations for applying loadings, etc. Each chapter of this manual has been developed by committees consisting of a conglomerate of private consultants, engineers, and suppliers. These individual committees draw information from railroad industry experiences, research, and work published by other associations such as AASHTO, AISC, ACI, AWS, etc.

Guidelines for load rating used herein were based on the bridge inspection /rehabilitation

program by the Massachusetts Bay Transportation Authorities (Brickenhoff, 2004). Two types of rating viz., inventory rating and operating are specified for load combinations. 


\subsubsection{Inspection Reports}

As bridges are prone to deterioration, damage and modifications, it is necessary to inspect and document the current condition of the bridge. This is done by inspecting a bridge and making changes to the as-built drawings to include the effects of any damage or deterioration. The AREMA Manual (2014) has a set of instructions for inspecting existing steel bridges in Section 15-7-2. Inspections can be classified as periodic, special and emergency inspections, and all may be visual or nondestructive testing. As per the Subsection 7-2-5 of Chapter 15 of the AREMA Manual (2014), the inspector should report findings like deterioration of steel, length and growth of cracks, amount and location of section loss and indications of failure in any part of the bridge. Reference points of deflection, misalignment and settlement must be identified and noted.

\subsection{Field Testing and Condition Assessment}

The behavior of two through plate girder railway bridges was investigated to determine a better approach to fatigue assessment (Philbrick, 1995). The bridges were instrumented, and the member strains and deflections were measured. These measurements were used to calibrate a parametric study of the analytical models of the bridges under applied loading. Their study revealed that the response of the plate girders is controlled more by the axle spacing's than the axle loads.

Observations made from a systematic study of a historic railway steel bridge built in 1896 was presented by Ermopulous (2005). Their study was mainly intended to assess the capacity of the bridge to carry enhanced train loadings, wind loads and seismic loads as per the French codes. Results indicate that strengthening is required in various minor components of the bridge deck. The relatively good condition of the bridge deck was attributed to systematic and periodic 
inspection and maintenance. It was concluded that the bridge can continue to be in service with suggested strengthening measures.

The performance and behavioral characteristics of an old through plate girder railway bridge were presented by Chotickai (2010). Strain gage instrumentation was used to monitor structural responses under current operating conditions. Their experimental and analytical results indicated that the stress responses of the bridge structure were controlled mainly by axle loads and axle spacing. The structure was shown to have an adequate capacity for current operating conditions. Their findings provided favorable information for performance and fatigue evaluation.

In a paper presented by Bacinskasa (2013), two locomotives were used to test a historic narrow gauge bridge built in 1936 and analytical models were developed based on the field tests carried out on the bridge. Responses of the bridge were measured regarding stresses, displacements, etc. It was concluded that the bridge exhibited sufficient reserve capacity for safe operation. Their work did not consider issues such as minor damages and cracking to the structure and movements of locomotives while loading.

All these works reviewed here revealed some useful findings relevant to the present work. Relevance to use of strain gage instrumentation to monitor structural responses, and the responses being measured regarding displacements stresses, using the data for calibrating the analytical studies, assessing the capacity of the bridge for enhanced train loadings, testing the bridge with original locomotive loadings and in terms of the load rating changes due to measurement changes found while inspecting the bridges. 


\subsection{Load Rating}

Theodore Cooper originally presented Cooper E-Loading system in 1880. AREMA later adopted it as a standard of bridge design loading. Cooper E 80 loading has been used as the standard for bridge design loading for steel structures since the year 1967 (AREMA, 2014). Cooper E 80 loading comprises series of axle loads and trailing load distributed uniformly, as shown in Figure 7. The " 80 " in Cooper E 80, represents maximum axle load as 80,000 pounds.

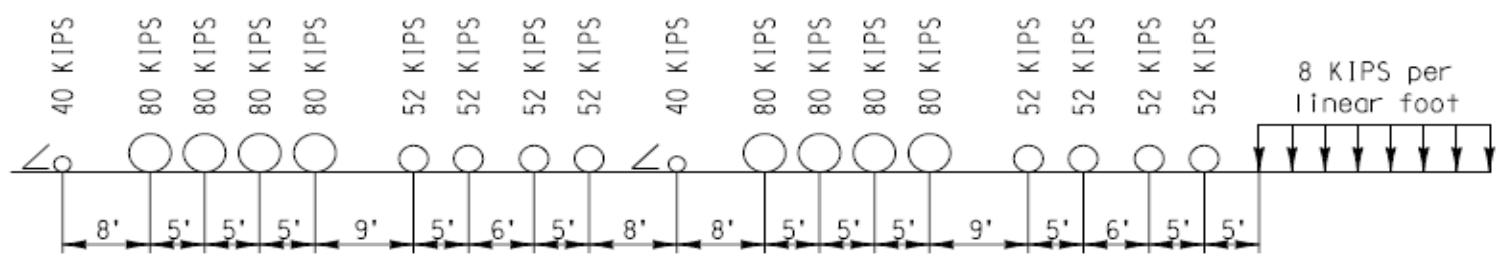

Figure 7- Cooper E 80 Loading, Maximum axle load 80 kips (Adopted from AREMA 2014 Chapter 15 Figure 15-1-2)

Bridge rating was done according to the AREMA 2014, Chapter 15, Parts 1 and 7. The Procedure described below is followed for a typical bridge component such as girder, floor beam and stringer for rating.

- Gather existing bridge information including record drawings, inspection data. Material properties and geometric properties of members are obtained from record drawings. When, recorded information is not available, geometric properties of bridge members are measured in the field during inspection. Material properties, such as yield strength are to determined either by coupon testing, or non-destructive testing, in the absence of record information. Further, AREMA 2014, Chapter 15, Section 7.3.3.3 provides guidance for an assumption of yield strength, and is applied for all rating calculations. 
- Compute the section properties (section modulus, the moment of inertia and area of the web, including any section loss at critical locations) of the members at critical locations to obtain bending moment and shear. Critical locations like center of the span for flexure and close to the bearings for shear.

Estimate allowable stresses in flexural compression and tension, and shear as per AREMA expectations, shown in Table 1.

Table 1 Allowable Stresses for Rating (Excerpt from AREMA 2014 Table 15-1-11)

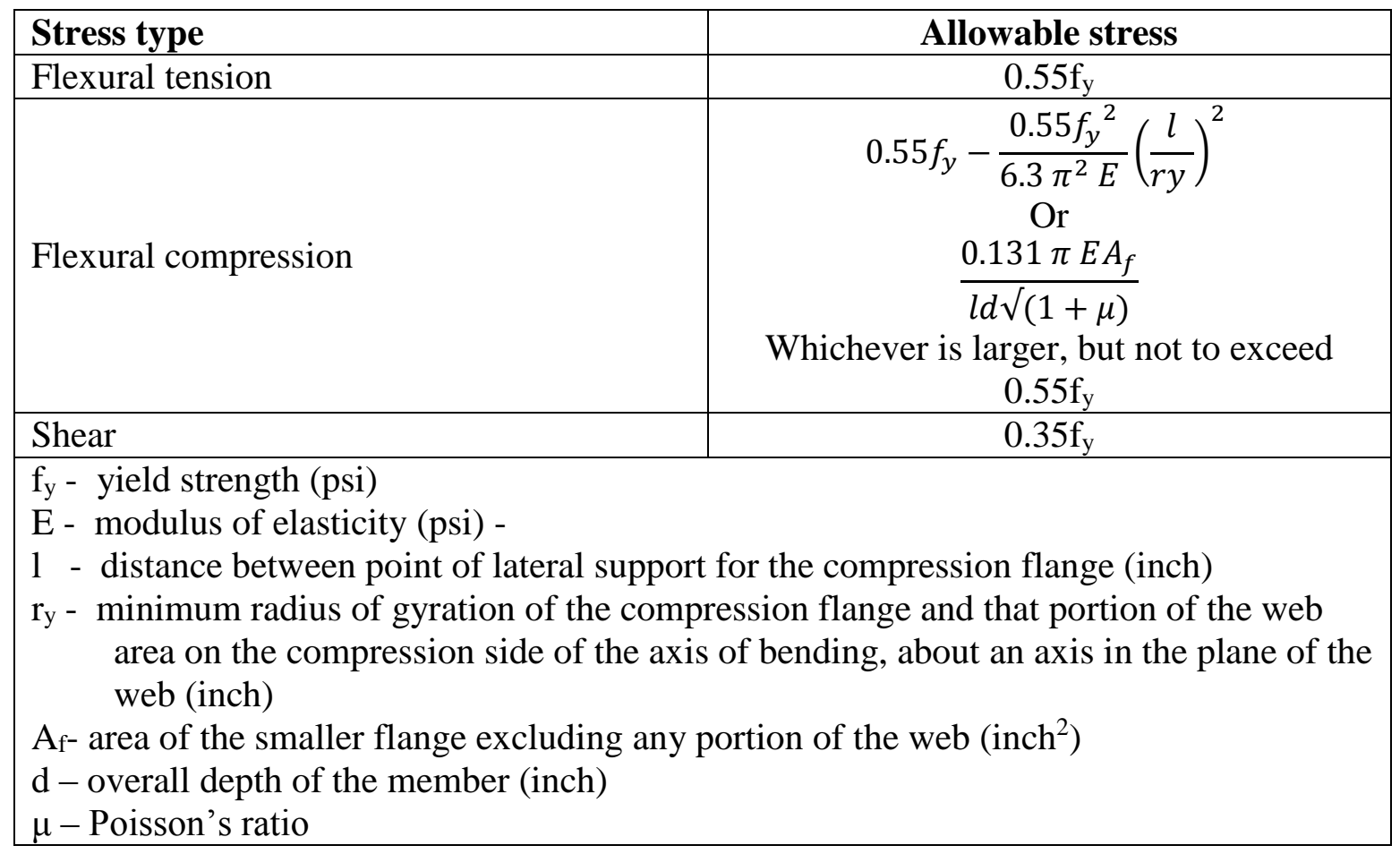

- Calculate deal load including self-weight of the bridge, deck, track, and other attachments that are permanently affixed to the bridge, including walkway, utilities etc. It is reasonable to ignore section loss for calculation self-weight.

- Cooper E 80 is chosen as reference live load (Section 1.4).

- Compute stresses induced by the total dead load and live load (Cooper E 80). Live load shall include impact (based on speed considered), rocking effect and centrifugal forces, as 
applicable. Live load shall be positioned giving maximum bending moment at shear at critical locations as described above.

- Find the ratio between allowable stress and the live load stress per bridge member (girder, floor beam, and stringer) and multiply by 80 ( 80 is for reference Copper E 80 load) to find Cooper E rating of the bridge members, based on shear or flexure.

- Compute live loads stresses under each equipment, i.e. GP 38 and GP 9 locomotives, and 286k railcar. Critical location for maximum shear and flexure shall be same as indicated earlier. The ratio of equipment induced stress to reference Copper E 80 stress, multiplied by factor 80 ( 80 is for reference Copper E 80 load) gives equivalent Cooper E rating of the equipment, for the particular bridge member.

- Equipment rating shall be compared to corresponding member rating for each stress type. Equipment rating less than member rating indicates a safe passage of equipment at speed considered.

The above process was used to rate member of Bridges at 1.4 and 5.8. Equipment rating for GP 38, GP 9 and 286k railcar was also calculated. The details of load rating analyses are presented in Chapter 4 and Appendix A though D, Table 8 and Table 9-Load Rating Results of Bridge 5.8 Members, in Chapter 4 provides load rating results of Bridges 1.4 and 5.8, respectively. Unsworth (2002) evaluated the load carrying capacity of a 336-foot span steel bridge built in 1893 and carrying heavy freight rail traffic. His method of evaluation involved detailed visual inspection and NDT, supported by a three-dimensional finite element analysis. His study revealed that many members of the steel arch bridge were deficient in terms of the load carrying capacity under Cooper E-80 loading and require strengthening. However, it was concluded that 
the bridge is safe as the remaining life of the structure is minimally affected and can carry vehicles weighing less than Cooper E-80.

Guidelines for load rating of Massachusetts Bay Transportation Authority (MBTA) transit bridges were prepared by Brickenhoff (2004) as a part of their bridge inspection/ rehabilitation program. These guidelines covered various loadings and load combinations for load rating. They form the basis for computing the maximum loads that can be allowed on the bridges under standard conditions (i.e., when the materials are of high quality and the members are in good shape). It also provides guidelines for when the existing bridges are deteriorating, in which case deductions in size and area will be made for the deteriorated portions. Allowable stress method forms the basis of these guidelines, involving computation of stresses in existing bridges and comparing with the allowable stresses. These guidelines are applicable for the existing bridges, and it is recommended to use the current relevant standards of AASHTO and AREMA for the load rating of newly proposed bridges. Deviations, if any, from these standards, are strictly advised to be documented, stating the reasons for such deviations, for the purpose of scrutiny and approval.

Bridges 2.40, 4.02 and 4.12 on the Burlington Branch in Chittenden County (Vermont state), were load rated and determined (Kirschling, 2012). The adequacy of each structural element was calculated as a percentage of the allowable stress for infrequent and regular traffic and were tabulated. It was concluded that the rating does not include the fatigue analysis. Bridge 4.12, can take 286 kips loading restricted to $25 \mathrm{mph}$ at infrequent intervals. A coupon test was suggested, taking the sample from selected locations in order to verify the bridge can operate regularly for the 286 kips loading. 
The works reviewed here provided useful information on the current global practices and issues in load rating of bridges, guidelines for various loads and load combinations and the significance of detailed visual inspection \& use of allowable stress method in the load rating of bridges.

\subsection{Fatigue Evaluation}

An overview of the effect of Heavy Axle Loads (HAL) on fatigue life of steel bridges in the North American freight railroad infrastructure was presented by (Unsworth, 2003). It was argued that in the context of increased axle loads and their repeated application on the railroads for the last over 40 years, there is a high need to consider the fatigue effects and evaluate them. A methodology for evaluation of fatigue strength and extension of fatigue life of the existing bridges was presented.

AREMA Chapter 15, Section 7.3.3.2 provides guidelines for fatigue evaluation and fatigue details categories are presented in AREMA Chapter 15, Table 15-1-9. Fracture critical members with detailed category D or more requires more attention, especially while inspecting. For bridges with five million or less gross ton per year train traffic with details less than category D, fatigue evaluation is not necessary. For bridges carrying more than 5 million gross ton train traffic per year, shall be evaluated for fatigue life, considering historic loads as well as future traffic.

Kliger (2009) reviewed the results of an extensive field investigation carried out on 100 steel rail bridges and categorized the damage cases according to the type of detail and the mechanism behind the fatigue damage. It was revealed in more than $90 \%$ of the cases, that the damages were of the deformation induced type and that an unintentional interaction was evidenced between the various load carrying members of the systems of bridges. 
In summary, the works reviewed reveal the influence of increased axle loads and their repeated application on the fatigue life of rail bridges, an importance of fatigue life evaluation is put forward. The inclusion of fatigue factor while evaluating the load rating analyses is a scope.

\subsection{Rehabilitation / Retrofitting of Steel Railway Bridges}

Steel bridges which are still in use beyond their original expected service life can create serious problems of deterioration due to aging. A strengthening method was presented by Lin (2013) integrating old steel railroad bridges with rubber-latex mortar, GFRP plates, and rapid-hardening concrete to increase its rigidity and by reducing the stress level and structure-borne sound levels of the old steel bridge. The mechanical performance of the rehabilitated hybrid bridge was investigated, and it is concluded that both experimental and numerical results indicate the rehabilitation method was effective in terms of enhancement of stiffness, reduction of stress levels of steel members and reduction of structure borne sound levels by $15 \mathrm{~dB}$ because of concrete and rubber latex coating.

Ghafoori (2015) presented the results of fatigue strengthened riveted beams of a 120-year-old metallic railway bridge using pre-stressed CFRP plates. The study shows a design criteria and Pre-Stressed Un-Bonded Reinforcement (PUR) system developed for strengthening. Unlike other methods, the preparation of bridge surface is not required when CFRP is used. It proved the decrease in time needed for on-site strengthening. A constant life diagram principal is based on developing analytical formulations to determine the minimum CFRP pre-stress level required to prevent fatigue crack initiation. After the retrofitting was done, a Wireless Sensor Network (WSN) system was installed to monitor "the on-site CFRP stress levels and temperature of the retrofitted details" (E. Ghafoori, 2015). WSN measurements indicate the increase in CFRP stress 
levels due to increasing ambient temperature. Finally, it was concluded that this method was useful when the stress history due to prior traffic loading cannot be determined easily.

In contrast to the above method, the use of adhesively-bonded composite materials has led to greater advances in repairing aged metallic structures. Liu (2009) presented experiments to investigate the effectiveness of prevention of fatigue crack propagation upon the use composite material of CFRP and both single sided, double sided repairs are studied. Experimental results have proven that the crack propagation was reduced and fatigue life prolonged 2.2-2.7 times upon the application of double-sided normal modulus composite patches to steel plates. Upon the use of high modulus composite patches, fatigue life increased by 4.7-4.9 times. The key point for this increase in fatigue life is the bond width. However, there were no details mentioned about the fatigue performance of the bond between the composites and the metallic structure.

Wallin (2011) investigated two different strategies for the strengthening of a through-girder steel railway bridge. The structure is the Soderstrom Bridge located in the city of Stockholm, Sweden. The addition of arches under the bridge to lower the stress ranges for all structural members was one method and the other being the pre-stressing of floor beams which in turn increases the stiffness and transforms the mean stress levels in lower flanges from tension to compression. The results of two methods of strengthening in a model by dynamic analysis with moving train loads have been discussed. Both the methods showed some positive effect relating to the fatigue life. The conclusion was that a quantification of the measure is not possible without object specific experiments. The arch system has efficiently removed a large resonance peaks at 320 and $345 \mathrm{~km} / \mathrm{hr}$. Effective temperature variations over time on the arch method needed further studies. 
The works reviewed in this context mainly focus on the rehabilitation of long standing steel bridges. The rehabilitation measures adopted to cover the application of a wide range of materials such as rubber latex mortar, GFRP plates, CFRP plates. Further, different strategies like adding arches below the bridge deck and Pre-stressing the floor beams were also highlighted. Most of these measures were intended to enhance the fatigue life of the steel bridge structure. The need for studies on aspects like fatigue behavior of bonded composites and metallic structures and also the effect of temperature variations on the retrofitting measures adopted is also identified.

\subsection{Embankments and Its Stability}

\subsubsection{Analysis and Design}

The US-DOT (1988) developed a checklist and guidelines for reviewing the geotechnical reports, to aid engineers in their review of projects containing major and unusual geotechnical features. Table 3 of this manual, shown in Table 17 of Appendix F, provides the list of the required geotechnical engineering analyses for embankments and cut slopes, for different types of soils and bridges with different foundation and retaining structures.

Bellin (1993) explained the causes of problems in bridge approaches, embankment foundations and side slopes and stressed the need for thorough subsurface investigations before design and execution and the need for considerations in the design of anticipated loads, predicted settlements of foundation and subgrade soils and also the predicted failure surfaces of the side slopes of the embankments. He stated the need for protecting the side slopes of the embankments from the problems of stream erosion and roadway drainage. 
A guide to the design of bridge approach embankments subjected to inundation is developed by the Government of Australia, in the form of Engineering Road Note 6 (2003). The note also presents Stability Charts, that provide a simple and rapid method of designing the proposed slopes or of checking existing slopes for stability under rapid draw -down conditions.

A summary of information needs and testing considerations for embankments of bridges is given

in the WSDOT Geotechnical Manual (2013). The design considerations for various types of embankments such as rock embankments, earthen embankments and bridge approach embankments, are also given in this manual.

The Caltrans Geotechnical Manual (2014) has documented the standard practices for the investigation, design and construction of embankments. Issues pertaining to embankments, bridge approaches, and embankment widening and storm drainage are addressed in this document.

\subsubsection{Damage and Failure Patterns}

Case studies of the "Rainfall induced collapse of old Railway bridges in Norway" were presented by Heyerdahl (2013). The geotechnical behavior of some of the collapsed embankments were studied and the results of one such were presented. Unsaturated flow properties were taken in to consideration to explain the behavior. The paper had very good illustrations of the damages and collapses experienced by various old railway bridges in southern Norway (see Figure 8, Figure 9, and Figure 10). 


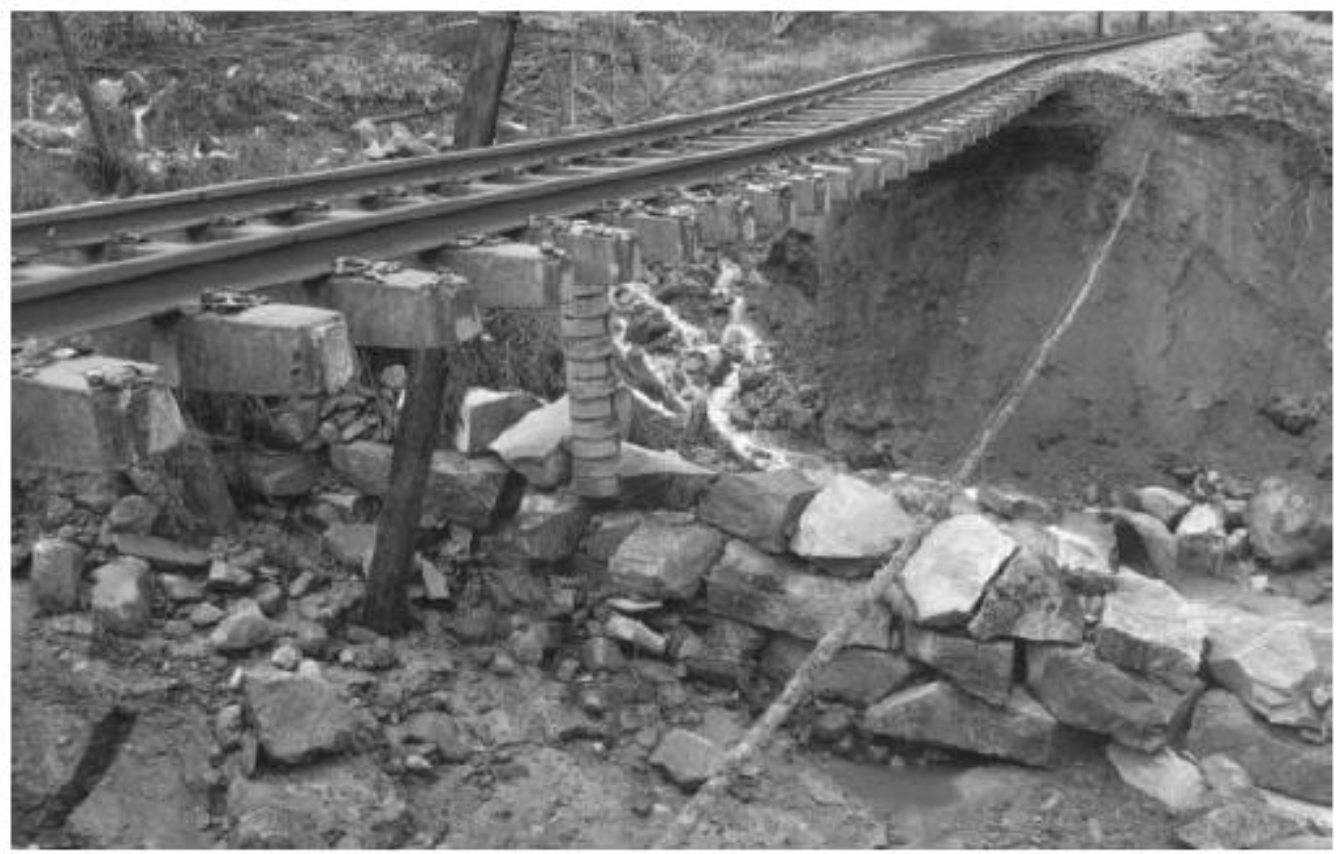

Figure 8- Destruction of Embankment Around a Culvert Due to Damming of Water on the Upstream Side of the Railway Line Between Oslo to Bergen in Norway (Heyerdahl H et.al, 2013)

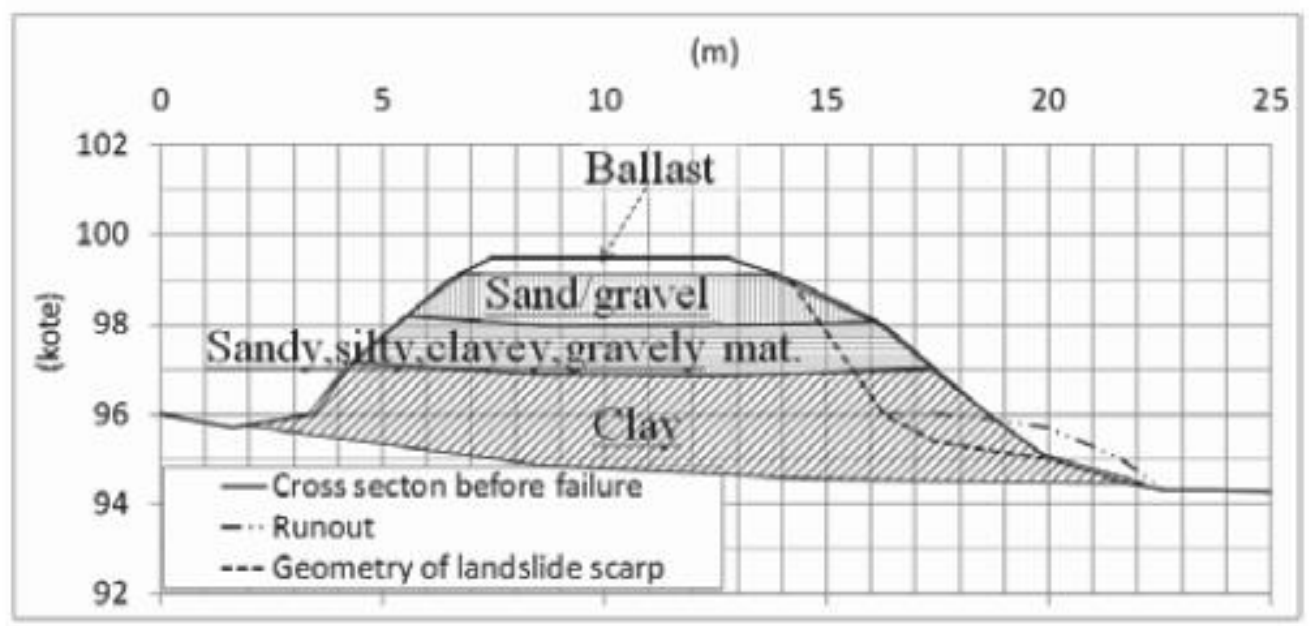

Figure 9- Total Destruction of Embankment Around a Culvert Due to Damming of Water on the Upstream Side of the Railway Line Between Oslo to Bergen in Norway (Heyerdahl H et.al, 2013) 


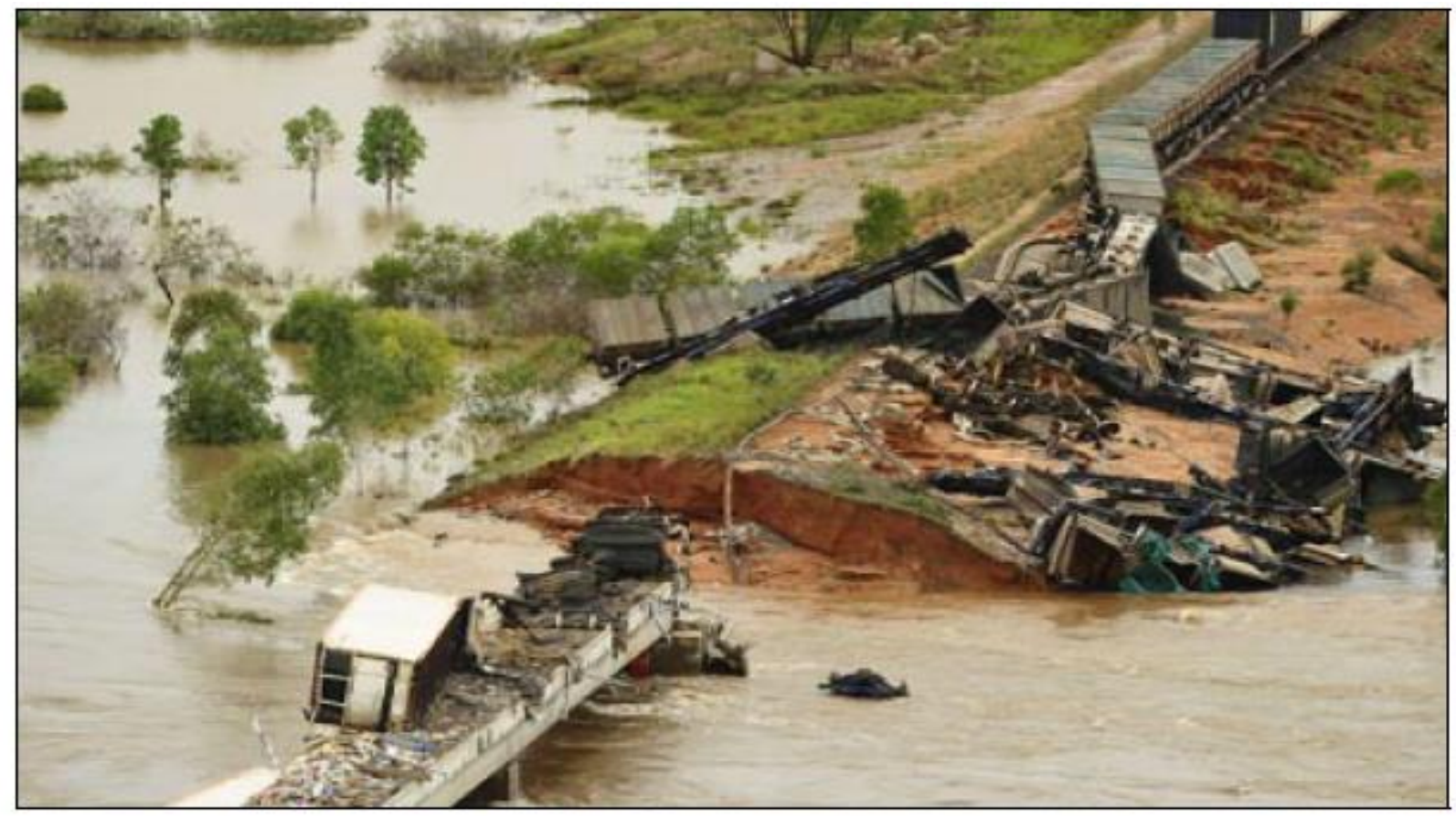

Figure 10- Derailment Caused by Failure of an Embankment Due to Scour During a Cyclone (Heyerdahl H et.al, 2013)

\subsubsection{Repairs and Rehabilitation Measures:}

The 2002 edition of Rail Engineering International (Beczkowski, 2002) reports that a machine called 'AHM- $800 \mathrm{R}$ track formation and rehabilitation machine has been successfully used for the track substructure renewal of Polish state highways (PKP), since 1999. The machine is shown in the following Figure 11.

Marko (2014) presented the application of various methods of rehabilitation of the existing transition zones on the old railway lines through the case study of Buna bridge of Croatia. 


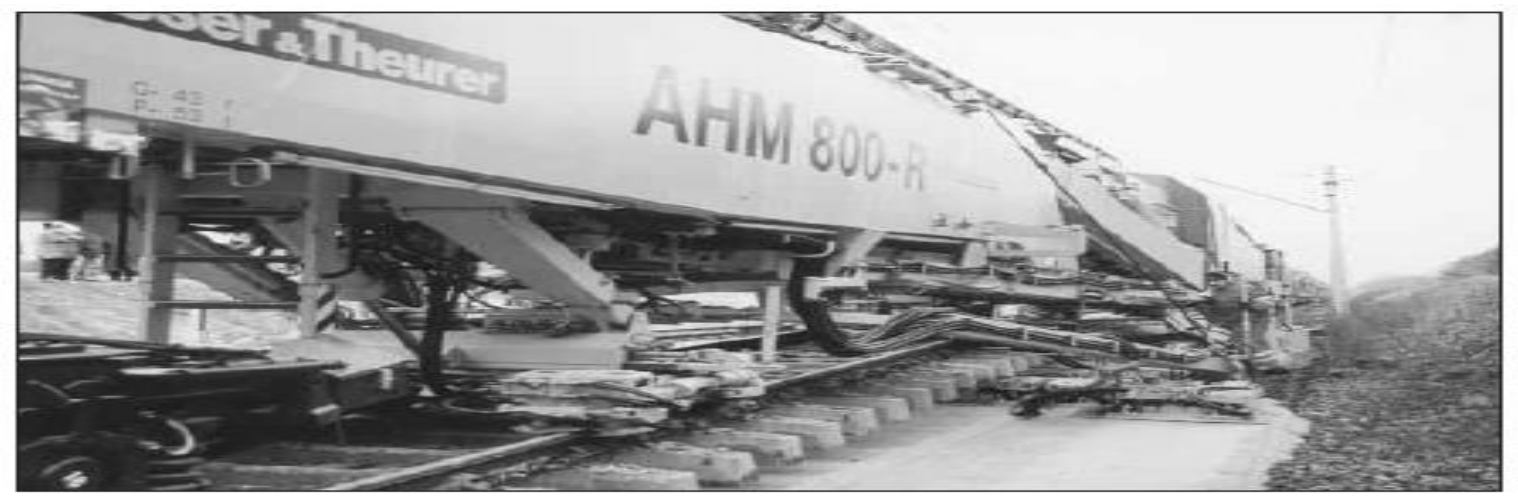

Figure 11- Raising the Track and Insertion of the New Formation Protective Layer Using AHM - 800 R

Assessment of typical problems in the existing old railway tracks and the rehabilitation methods for open track and transition zones were presented by (Gavin, 2014). The report also presents the methods of inspection of slopes and railway infrastructure using NDT Techniques.

Puppala (2009) brought out a technical report in the form of a document titled "Recommendations for design construction and maintenance of Bridge Approach Slabs - A Synthesis report". The report is an outcome of a comprehensive review of the past research on the subject and a detailed survey conducted in all the 25 districts of Texas State, to understand the local conditions that contribute to the bump problem (differential settlement at the area between the bridge and roadway interface) in bridges.

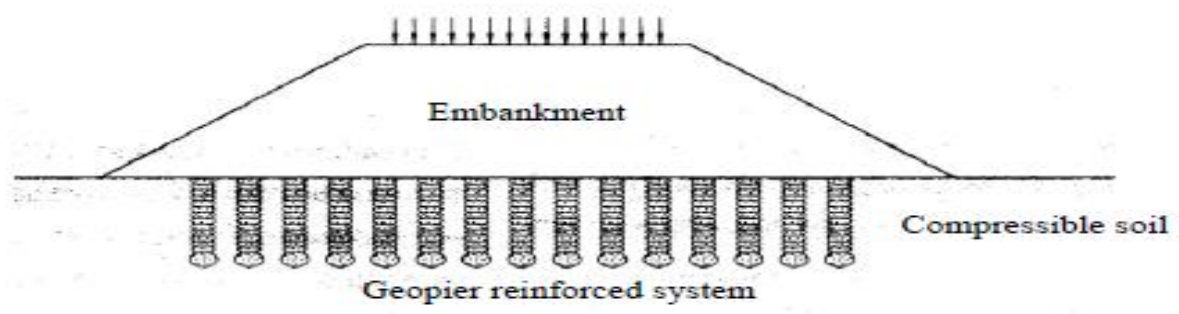

Figure 12- Typical Geo Pier System Supporting the Embankment (Lien and Fox, 2001) 


\subsection{Summary}

A summary of the literature review conclusions is shown below.

Inspections procedures became much stricter and provisions were developed for FCM's and implemented so that fatigue induced fractures are rare in bridges.

The experimental and analytical results of bridge testing indicated that the stress responses of the bridge structure were controlled mainly by axle loads and axle spacing.

For bridges with five million or less gross ton per year train traffic with details less than category $\mathrm{D}$, fatigue evaluation is not necessary.

Strengthening methods such as integrating old steel railroad bridges with rubber-latex mortar, GFRP plates, and rapid-hardening concrete to increase its rigidity and by reducing the stress levels, structure-borne sound levels of the old steel bridge, using prestressed CFRP plates, and adhesively-bonded composite materials are some of the examples of advances in rehabilitating steel structures.

$>$ A brief scope for embankment slope integrity studies, failure patterns and rehabilitation procedures were discussed in this chapter. 


\section{Chapter 3 \\ FIELD INSPECTIONS}

\subsection{Introduction}

To purpose of field inspection is to assess the condition, measure section properties and to note any section loss due to corrosion. The chapter discusses the description of the structures, observations made while inspecting the bridges and its embankments. The general requirements of the inspections were followed as per those stated in the AREMA Manual 2014, Chapter 15, Section 7.4.

\subsection{Bridge Description/Condition Report}

As a part of the visual inspection by WVU-CFC, a classification was used for inspection findings in four categories $(\mathrm{C} 1, \mathrm{C} 2, \mathrm{C} 3$ and $\mathrm{C} 4)$ as shown below.

- C1- Prompt attention needed. Repair within 30 days.

- C2- Recommended repair within nine months.

- C3- Recommended repair within 3 years

- C4- Monitoring the condition at each annual inspection

Inspection reports by WVU-CFC are included in Appendix F. The current condition and description of structures of Bridges 1.4 and 5.8 are discussed in the following Sections 3.2.1 through 3.2.4. 


\subsubsection{Description of Bridge No. 1.4}

Bridge 1.4 is a two span simply supported through-girder type bridge. The two plate girders in each span support the floor beam-stringer system (including diaphragms and bracings). The stringers (two in number, spaced $3.25 \mathrm{ft}$. on either side of the longitudinal center line) are framed between the floor beams, with ties placed over them and the rails anchored to the ties. The web of the plate girders is attached to the cover plates with two angles on the top flange and two angles on the bottom flange (each leg of the angle being 7.94 inches wide and 0.6875 inches thick). The top and the bottom flanges have three cover plates at mid span and only one cover plate at the top at the supports. Intermediate stiffeners are riveted to the web to stiffen the web panel. The distance between the intermediate stiffeners increases towards the center of the span as compared to near the supports. Inclined steel plate bracing connects the top of each floor beam to the web. The two simply supported spans vary in length with span 1 being 97.042 feet and span 2 being 95.573 feet. Each span has ten floor beams and 18 stringers, with varying distances between the floor beams. Since the ties are placed on the stringers, the load path will be stringers to floor beams to the plate girders to the substructure. Bridge 1.4 has two abutments each having two wing walls, and one pier in between two abutments. The north end of span 1 is supported on a segmented rocker bearing on abutment 1 as shown in Figure 13 and the south end is supported on the fixed pin bearing on the pier. Span 2 of the bridge has similar support arrangement, but it starts on the pier and ends on abutment 2 . The entire riveted super structure along with the cross sections of primary members (plate girders, floor beams, and stringers) is shown in Figure 14, Figure 15, Figure 16, and Figure 17 


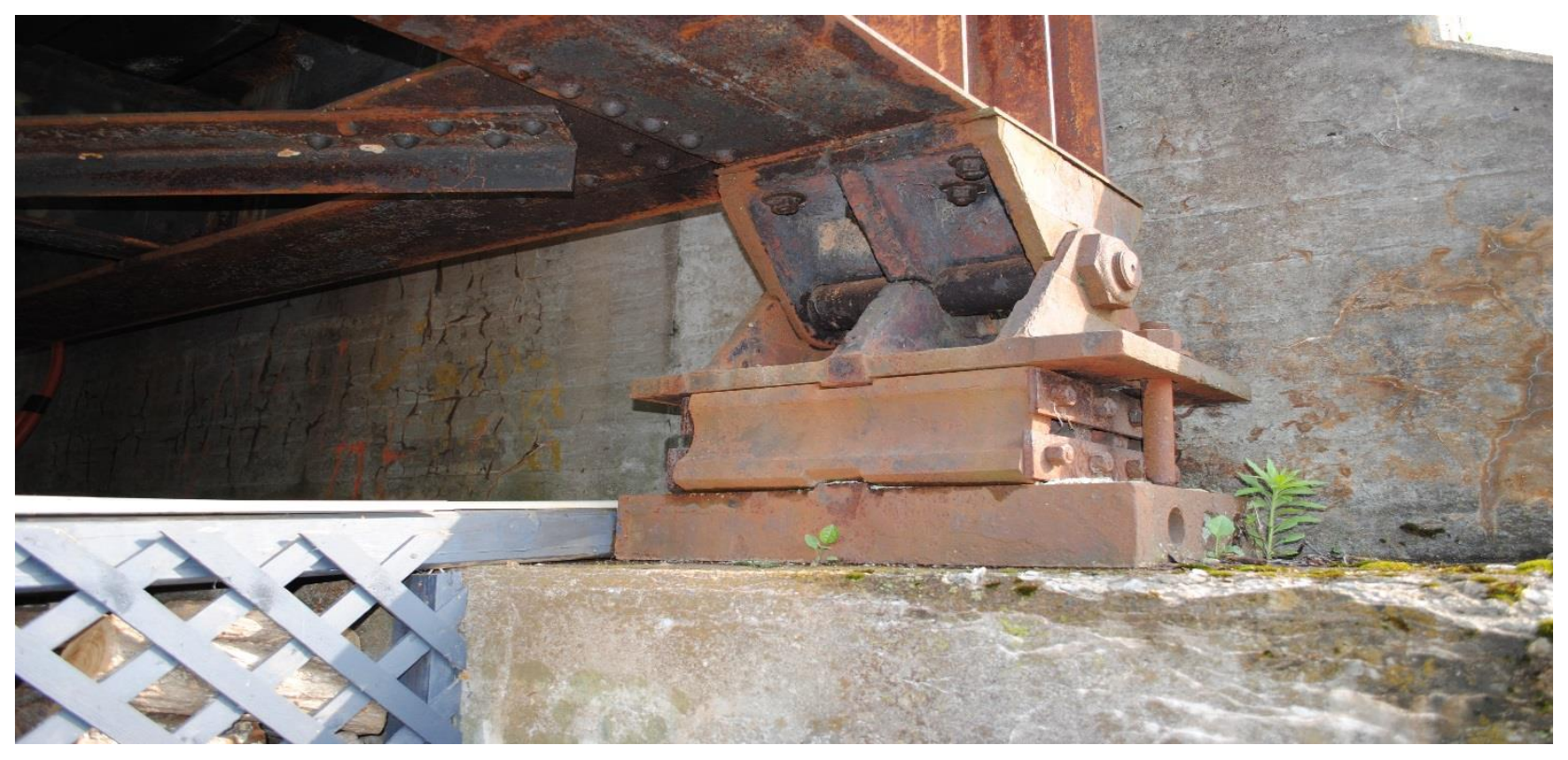

Figure 13- Segmental Rocker Bearing on Abutment 1.
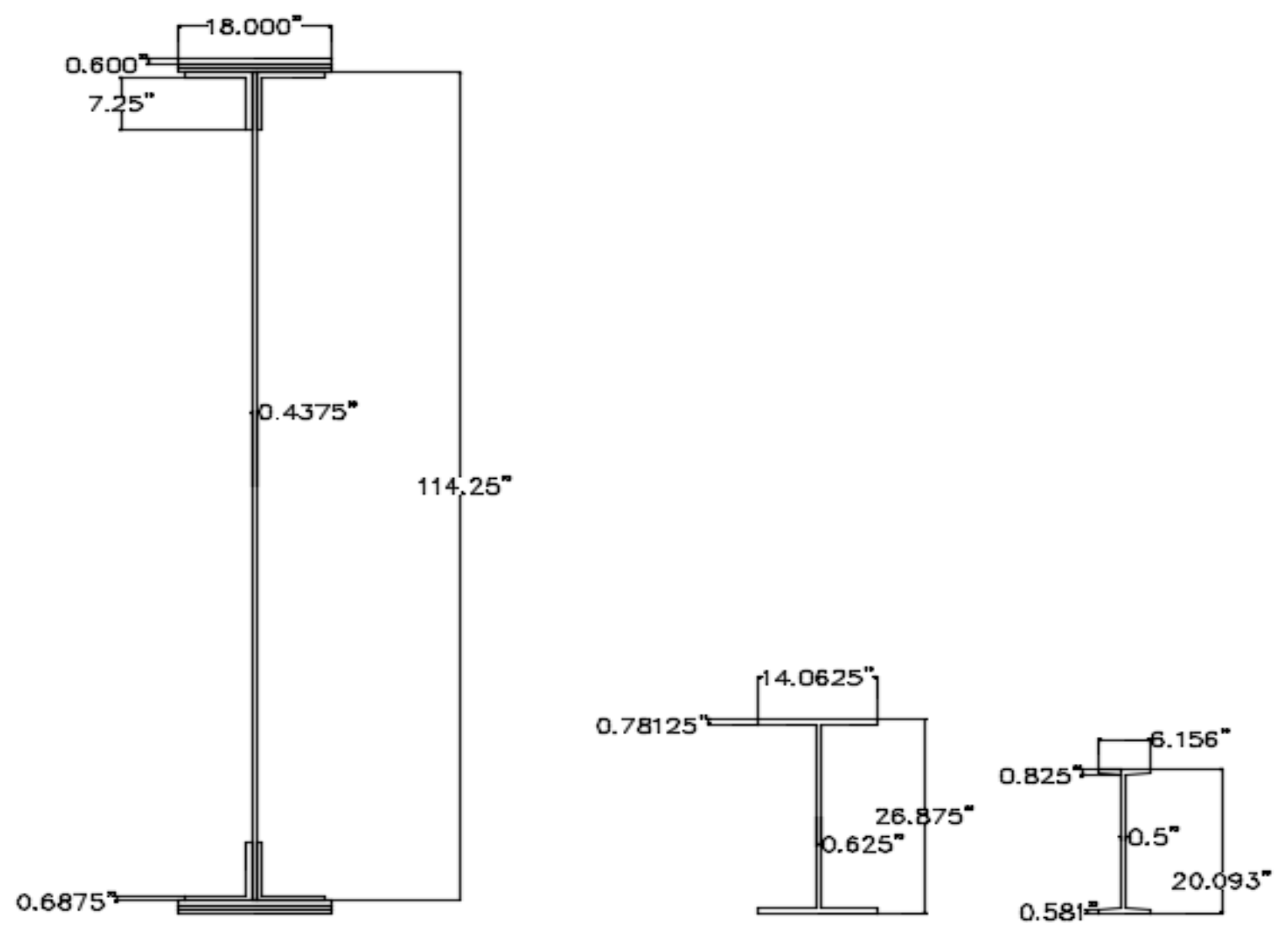

Figure 14- Dimensions (inches) of Plate Girder at Mid Span, Floor Beam, and Stringer of Bridge 1.4 


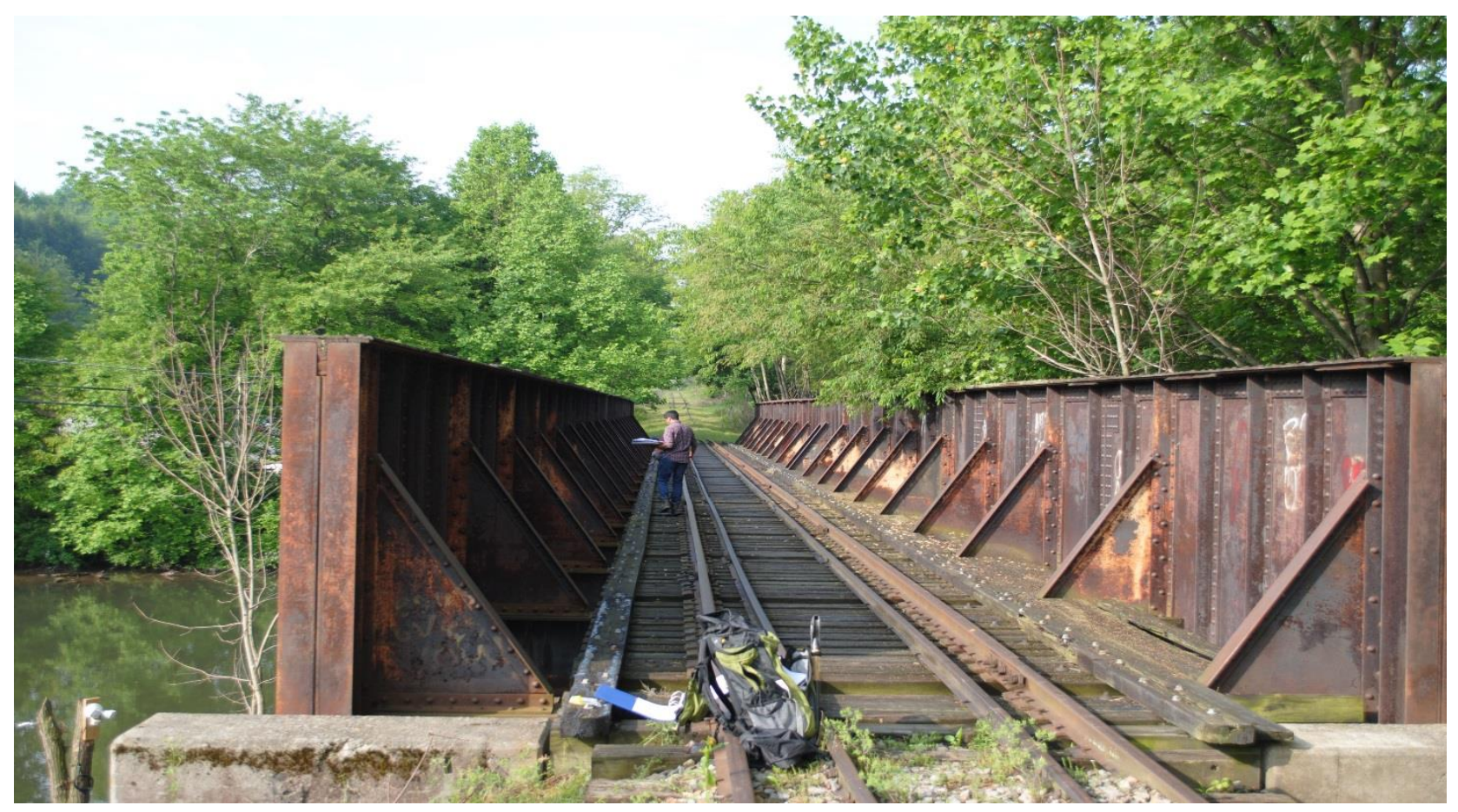

Figure 15- Top View of Bridge 1.4 From North End.

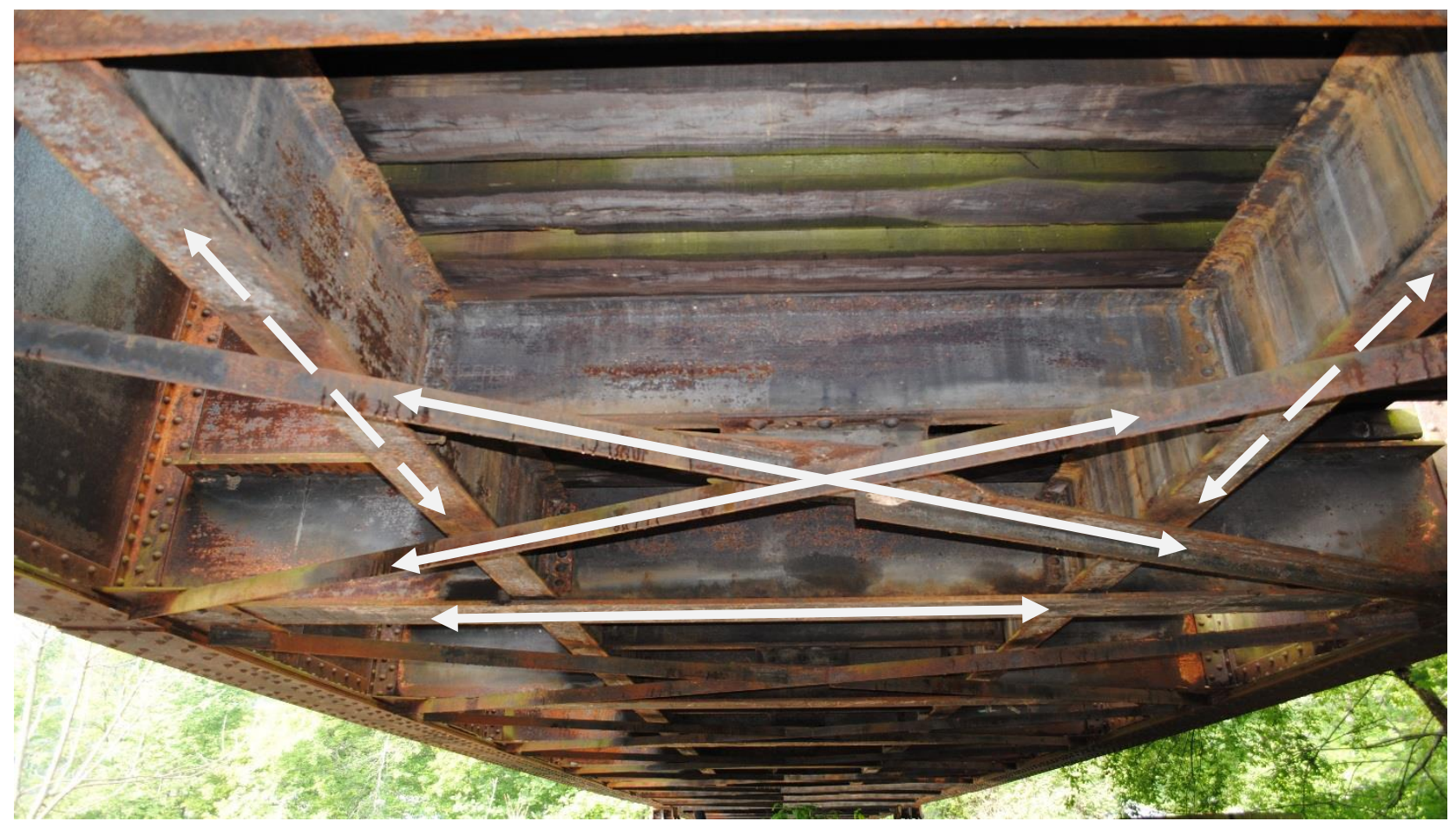

Figure 16- Bottom View of Bridge 1.4 - Marked are floor beams (horizontal line), stringers (dotted lines) and cross bracings (cross lines). 


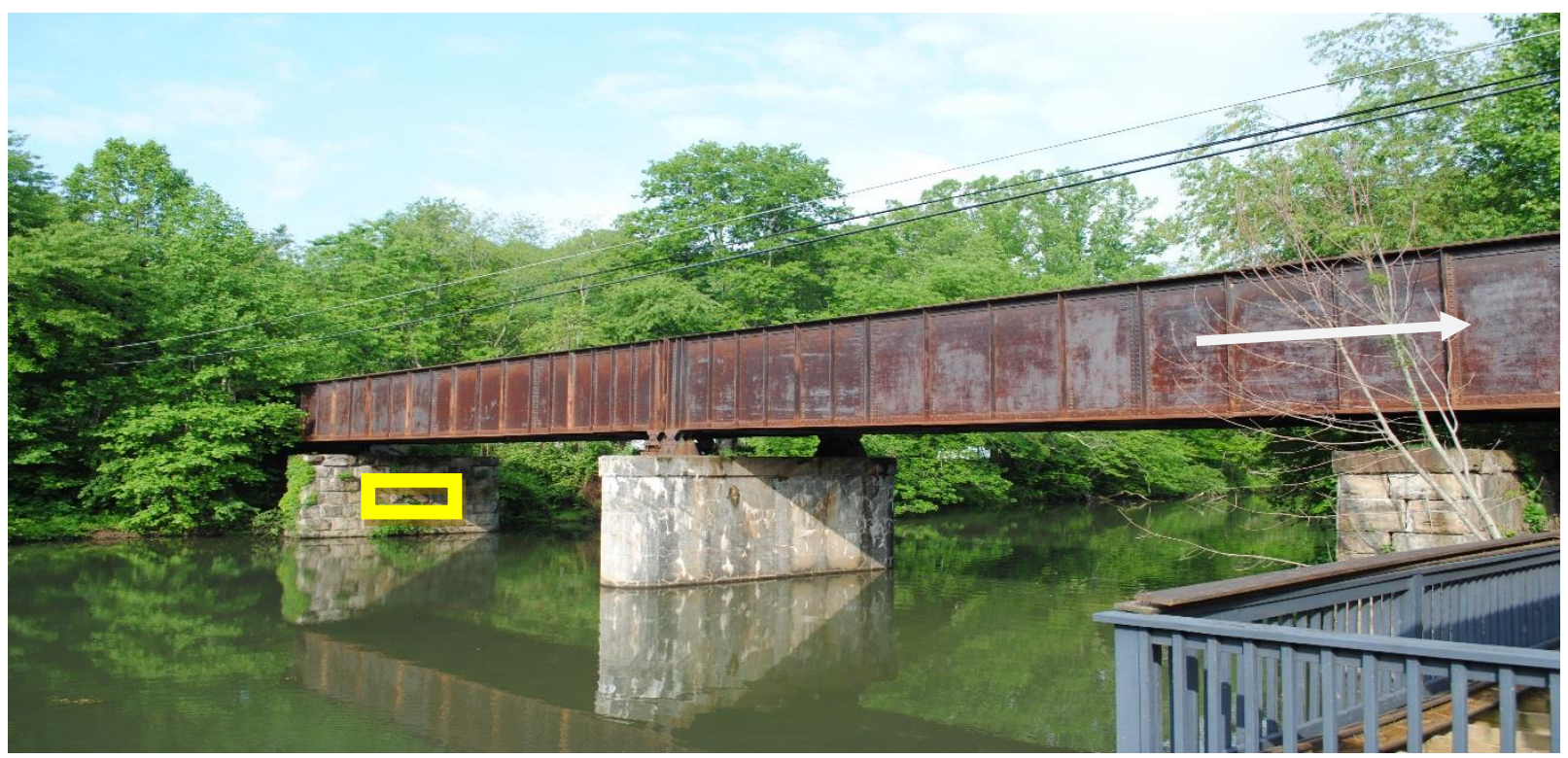

Figure 17-Side View of Bridge 1.4 (North indicated by arrow)

For inspection convenience, the plate girders are numbered 1,2,3,4. Girders 1 and 2 are located in the West and East sides of span 1, respectively. Girders $3 \& 4$ are on the East and West sides of span 2, respectively. A plan view of the bridge is shown in Figure 18.
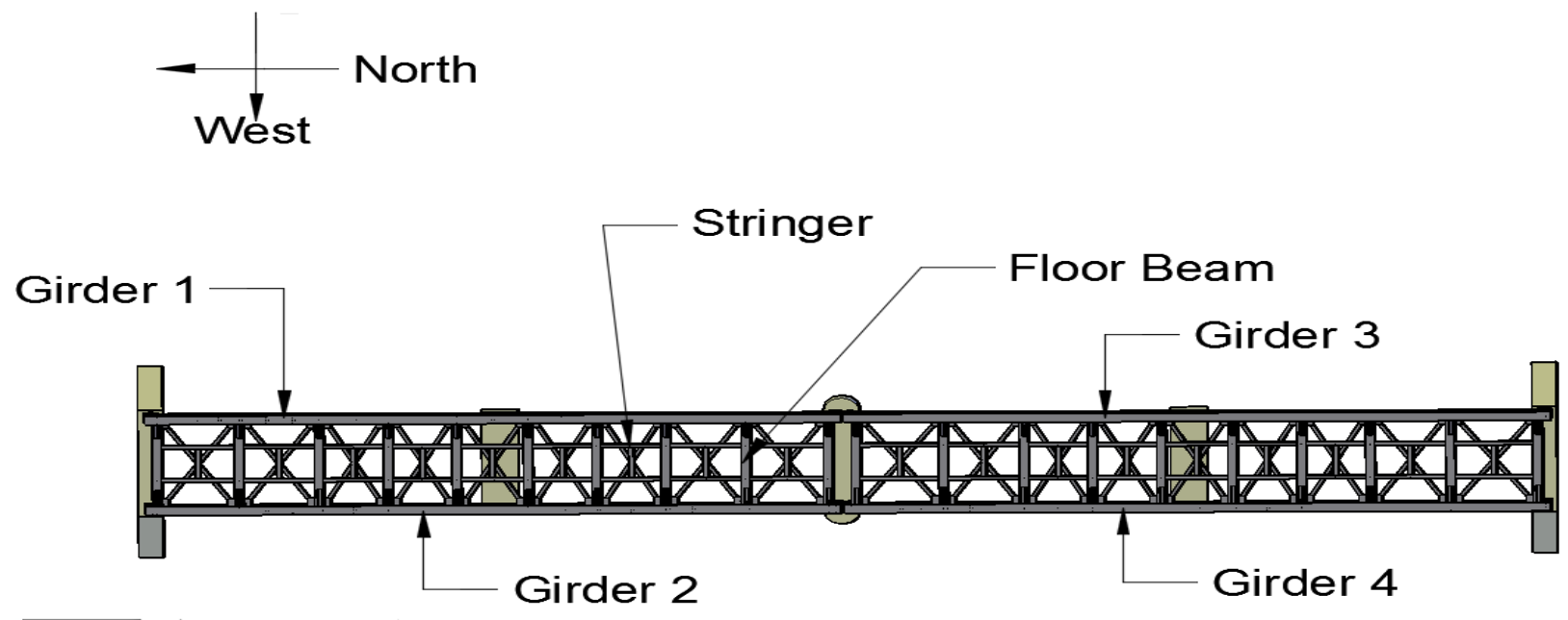

Figure 18- Representation of Bridge 1.4 


\subsubsection{Inspection Findings}

The superstructure that could be accessed and part of the substructure that was visible above the water level were inspected by WVU-CFC in May, 2014. The emphasis was primarily placed on the areas of maximum moment and shear, connections (gusset plates, rivets, and floor beamstringer connections), and bearing areas to check for cracks and corrosion.

\section{Plate Girders:}

The plate girder elements were inspected including noting any missing or loose rivets. Visual inspection included section loss and severity of corrosion. The visual inspection found that the areas around rivets had minor bleeding rust, but the rivets were tight. The top and the bottom flanges of all four girders did not have any cracks. The interior bottom flange angle on the northwest end of the girder 2 exhibited significant corrosion as shown in Figure 19.

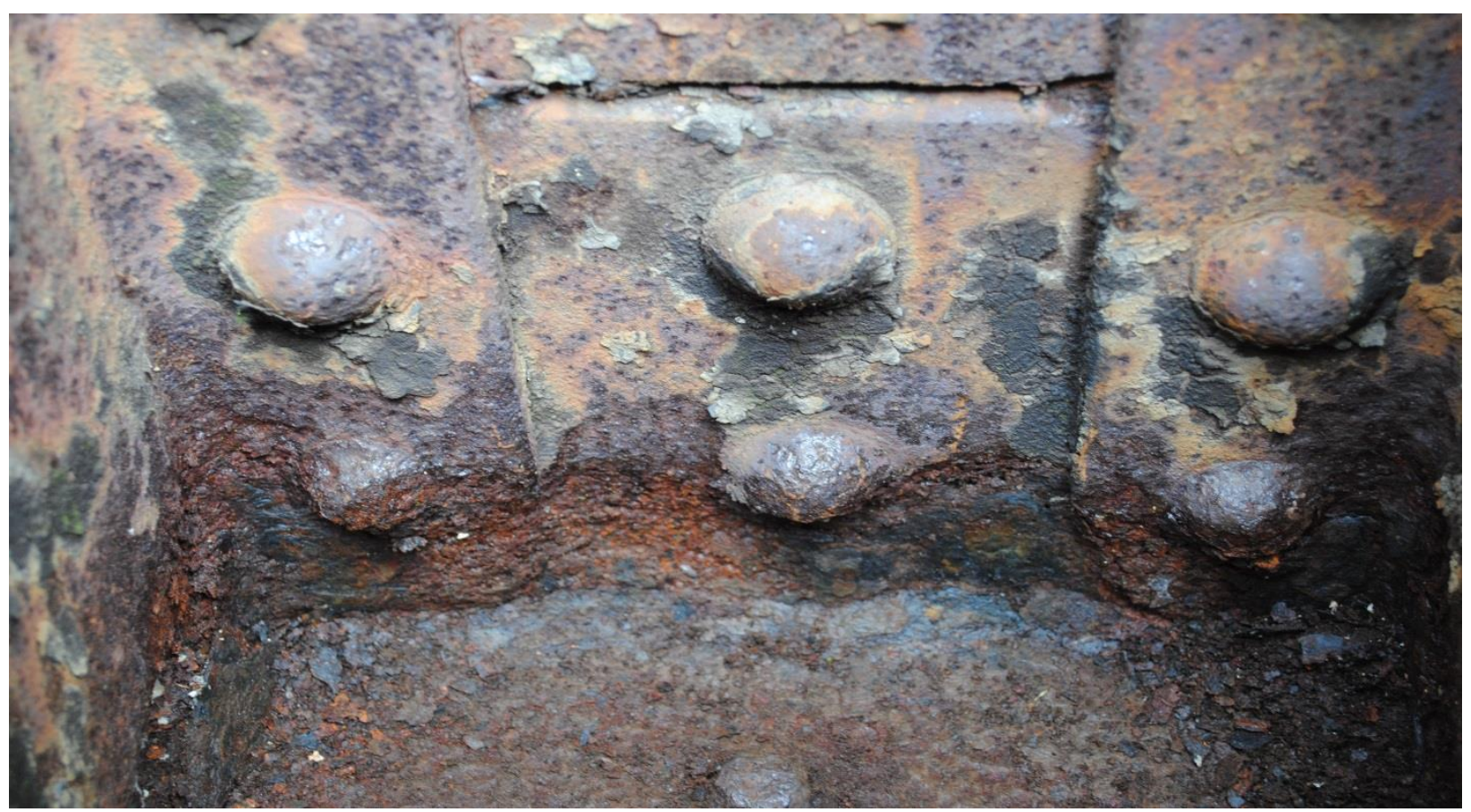

Figure 19- Severe Corrosion Activity Seen on the Interior Bottom Angle of Girder 2 at the North-West End 
The exterior angle of the bottom flange of girder 1 is bent as shown in Appendix Figure F6. The web had no signs of cracks. One of the end bearing stiffeners attached to the web had locally $100 \%$ section loss as shown in Figure 20. This section loss might affect the bearing strength of the stiffener and might trigger a local buckling of the web and as discussed in a paper by Khurram (2014) and as shown in the Figure 21 . Hence, replacement of stiffener is recommended.

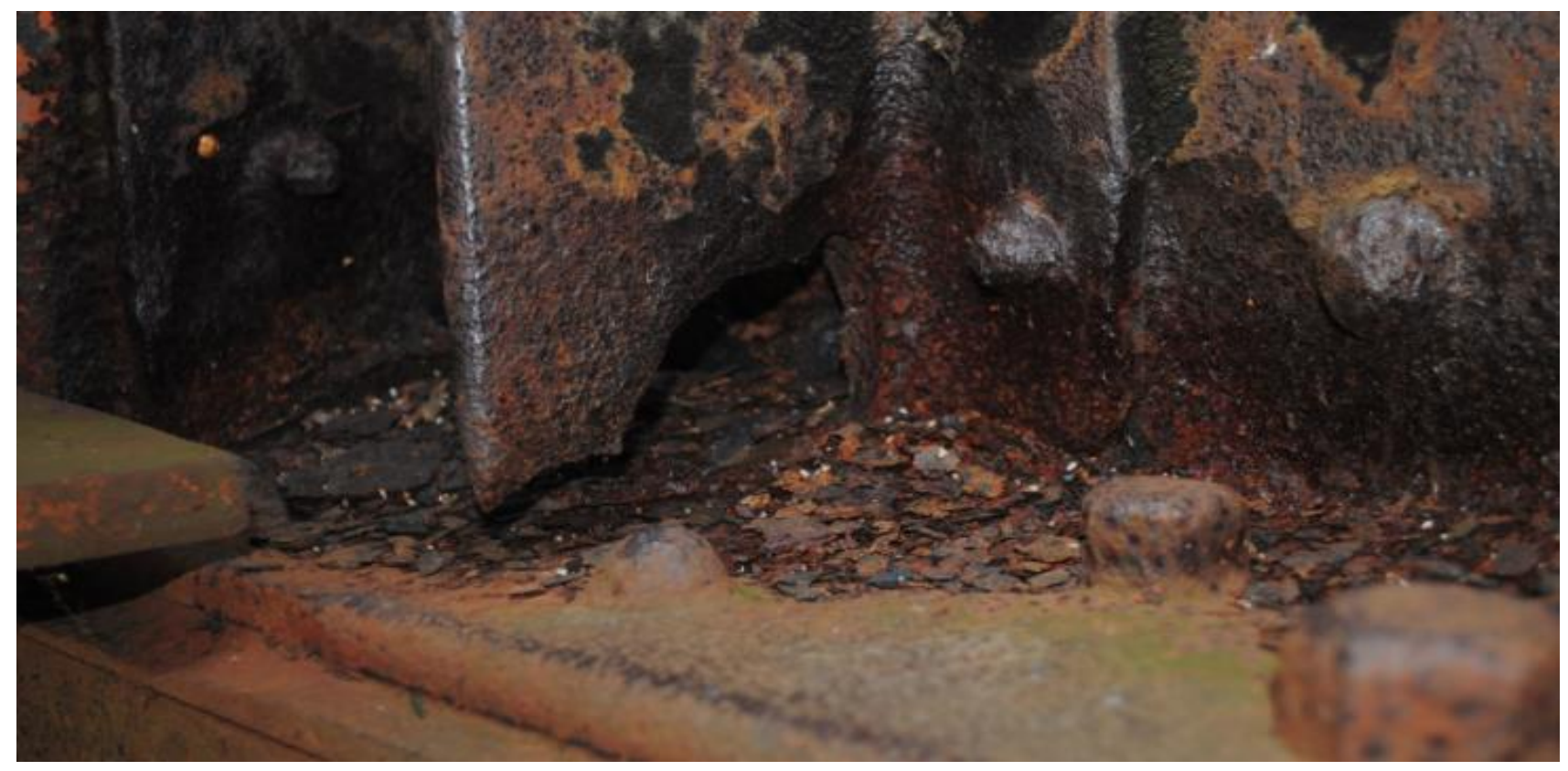

Figure 20- Bottom of the Stiffener of Girder 2 (Span 1, Center) with 100\% Section Loss. 


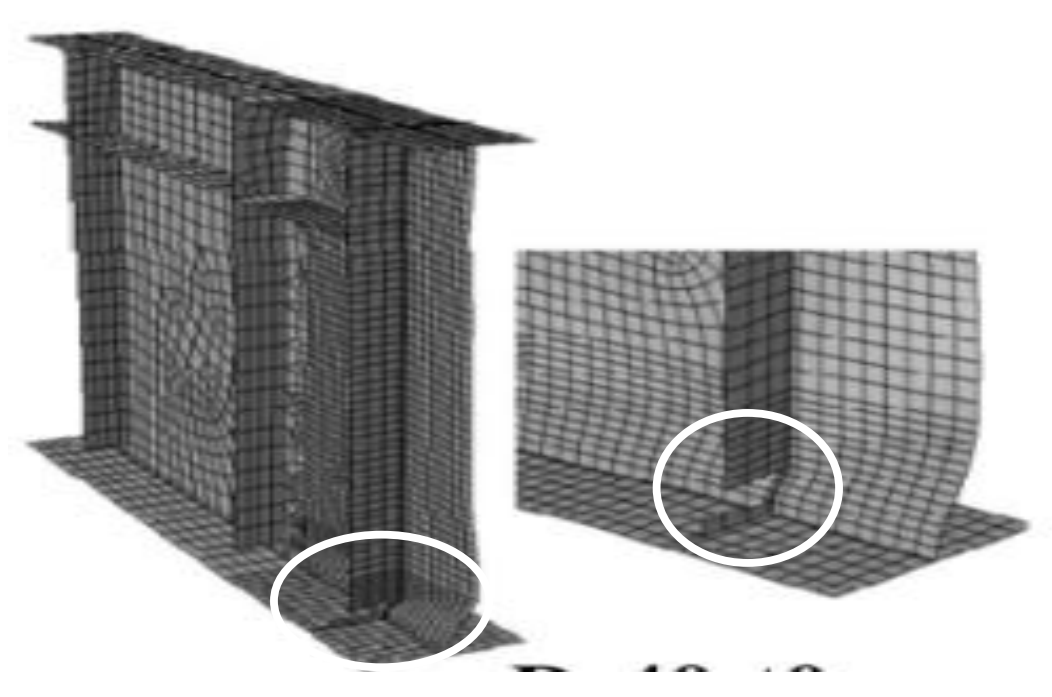

Figure 21 - Web Crippling at The Bottom of the Web Due to Loss of Section of The Bearing Stiffener, (Khurram, 2014).

\section{Floor beams, stringers, lateral bracing:}

The floor beams, stringers, and lateral bracing did not have any defects. Minor surface rust and loss of paint were the only observations for floor beams and stringers. The gusset plates of the lateral bracings near the north end had holes up to half inch diameter, but were still structurally functional and should be painted and monitored.

\section{Classification:}

The inspection findings of the components of Bridge 1.4, were placed under category C3 and C4. Some recommendations are provided herein to keep the safe function of the bridge in view.

C3:

- Slopes: As the slopes are steep, there was loss of ballast. Building timber walls is suggested to maintain ballast.

- The wooden walkway is in poor condition and should be replaced. 
- Coning was observed at the bottom 1" of anchor bolt of the northwest bearing. The anchor bolt was inclined towards the south; the bearings have to be reset and the anchor bolts have to be replaced.

\section{C4:}

- Steel girders: Loss of section due to corrosion could be accelerated due to presence of, debris. The bottom flange angles are fracture critical components; hence, proper maintenance should be performed to address corrosion of steel. Immediate repair or replacement is not the primary recommendation. After cleaning of debris, loss of section measured is about 0.25 inches, however this occurred in the inside bottom flange close to the bearings. Hence, integrity of the structure is not affected.

\subsubsection{Description of the Bridge 5.8}

Bridge 5.8 is a single span (17.875 feet) deck plate girder bridge. The superstructure constitutes two plate girders, bracings and ties. The plate girder on the west side is numbered as 1 and that on the east side is numbered as 2 . The two plate girders are formed by riveting angles, web plate, and stiffeners together. Above the two supports, the two plate girders 1 and 2 are braced together transversely. The entire arrangement of the superstructure is supported on the substructure consisting of two masonry abutments. The entire bridge system is shown in Figure 22. 


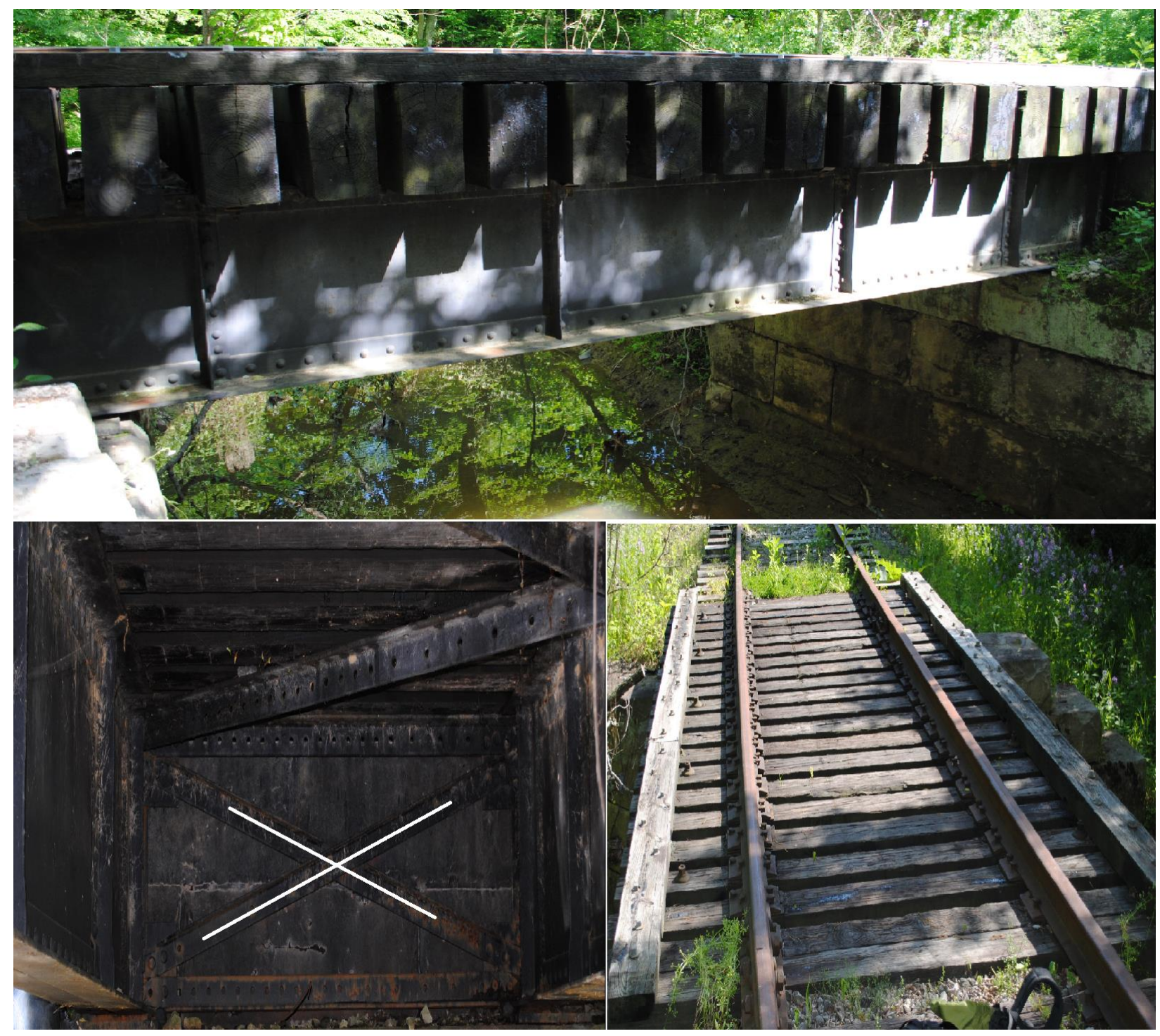

Figure 22- (Top) Side View of The Superstructure from Northwest Direction. (Bottom Left) Bottom View of Superstructure - Marked are Vertical Cross Frame/ Diaphragm (Cross Lines), and Horizontal Cross Bracings. (Bottom Right) Top View of the Bridge at Milepost 1.4 (North Side of the Bridge is Towards the Bottom of The Picture).

The abutment towards the north side is numbered as 1 and towards the south as 2 . The inspection findings are tabled from north to south. The inspection charts can be found in Appendix F. 


\subsubsection{Inspection Findings, Bridge 5.8}

\section{Plate Girders:}

The plate girders have minor surface rust on the bottom flanges for both girders 1 and 2 . The interior bottom flange of girder 1 is very slightly bent as shown in the Figure 23, the reason is unknown. The paint is in satisfactory condition for most of the surface.

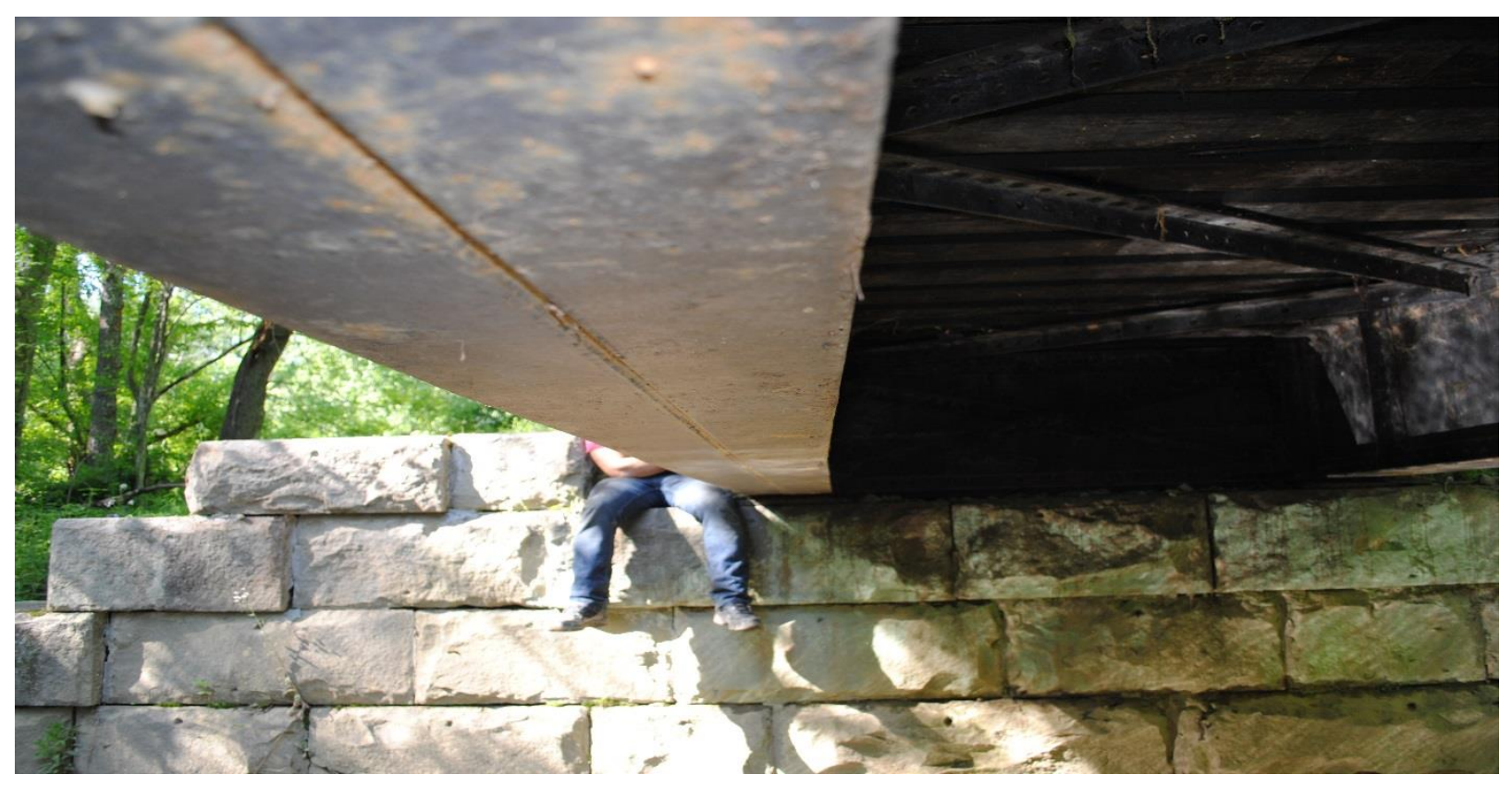

Figure 23- Bent Interior Bottom Flange of Girder 1

\section{Cross Frames, Lateral Bracing and Stiffeners:}

The cross frames at both the ends have minor rust, the bottom rivets in the southwest and southeast ends have minor bleeding of rust, but were tight enough to hold the parts (bottom view). The gusset connections of the lateral bracing had minor corrosion. Except for one stiffener, all other stiffeners are in good condition. The exterior stiffener near the northwest end is bent at the top as shown in Appendix Figure F15. 


\section{Classification:}

C3:

- Slopes: As the slopes are steep, there was loss of ballast. Building timber walls or using gabions were suggested to maintain ballast level.

- Abutments: Loss of mortar in between the capstones was noticed. Epoxy grouting and surface finish may help to fill the gaps.

\section{C4:}

- Wing walls: The wing walls also have gaps between stones and the capstones are offset 2" from lower stones. It is recommended to align the stones of abutment and to fill the gaps with epoxy grouting. The gaps and alignment are not a serious threat to the bridge.

Clean the surface rust and painting is suggested. The bent bottom flange might be a manufacturing mistake. Does not look a failure due to loading, monitoring is suggested.

\subsection{Embankments of Bridges at Mileposts 1.4 and 5.8}

The embankments of both Bridges 1.4 and 5.8 were inspected during the field visits for their condition assessment and to suggest possible retrofitting measures, if needed. However, for both these bridges, embankments were found to be safe and stable. Additionally, their safety aspect is doubly ensured as none of the damage or failure patterns (shown in Figure 8 Figure 9, Figure 10) described in Chapter 2 (such as slip failure, scour failure, destabilization of slopes, etc.,) were witnessed. Besides these aspects, natural vegetation is seen to be existing on the slopes of the embankments (Figure 24, right), which contributes for slope stability. 


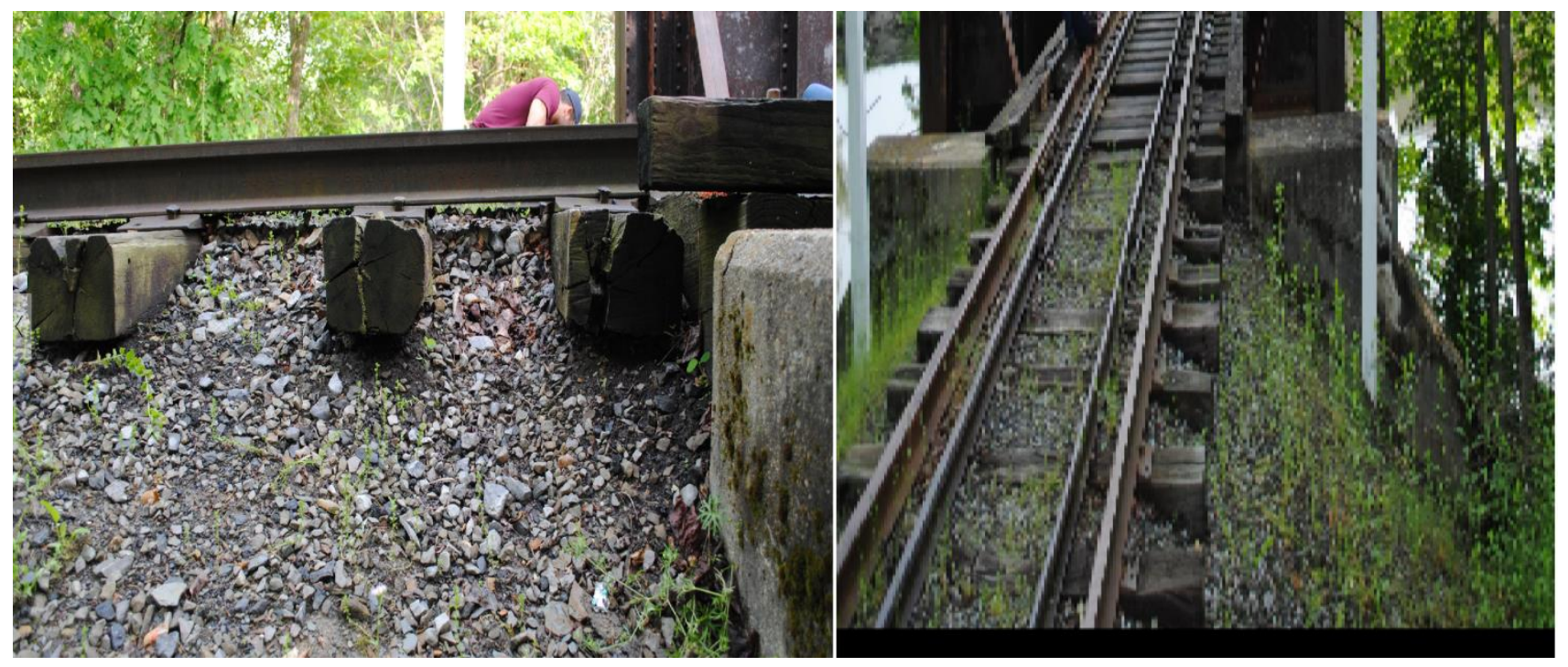

Figure 24- (Left) Gap Between the Tracks and Sub Grade of Bridge No. 1.4 Approach Embankment. (Right) Vegetation is Seen on Slope of the Embankment of Bridge No. 1.4.

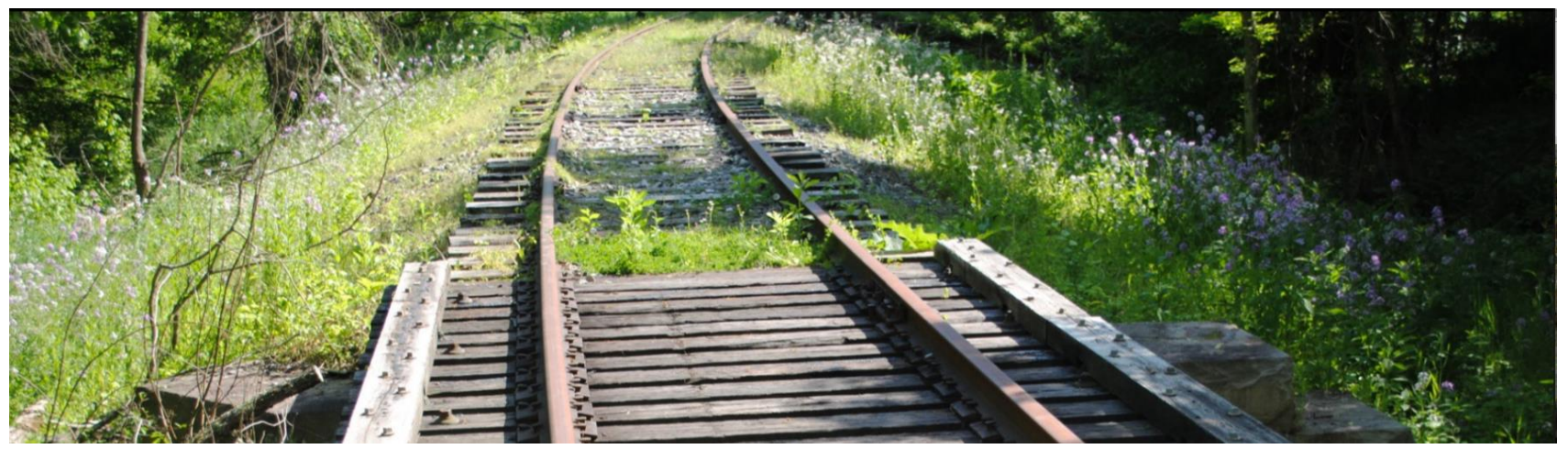

Figure 25- Approach Embankment of Bridge No. 5.8, Vegetation can be Seen on the Embankments and on The Area Between the Rails.

There was no evidence of any settlement or disruption of embankments. In view of these findings from the visual inspections, no retrofitting measures are recommended for the embankments of Bridges 1.4 and 5.8. However, gaps were observed between the track and the subgrade (shown in Figure 24, left), which is attributed to draining out of the ballast along with the loosened surface material. This further emphasizes poor ballast maintenance on the bridge approaches. Over a long period, long-term heavy compaction and vibration effects of the moving 
loads on the tracks causes lateral movement of the ballast and the surface material of the subgrade; i.e. the ballast slips down the side slopes of the embankments. Regular inspection is recommended for the track and embankments of both the bridges. As a part of maintenance, building of timber walls to prevent the sliding of ballast is suggested. This avoids further increase in the gap and thus prevents the need for an expensive maintenance in future.

\subsection{Field Inspection Summary}

The details of the visual inspection of the Bridges 1.4 and 5.8 are presented in Appendix F.

The key findings along with the maintenance suggestions are summarized below

\section{Bridge 1.4:}

- The slopes are steep, there was loss of ballast. Building timber walls is suggested to maintain ballast.

- Coning was observed at the bottom 1" of anchor bolt of the northwest bearing. The anchor bolt was inclined towards the south; the bearings have to be reset and the anchor bolts have to be replaced.

- After cleaning of debris, loss of section measured about 0.25 inches deep was found. This occurred on the inside bottom flange close to the bearings, where, there is more chances of moisture being collected more, and this can enhance the corrosion. Hence, monitoring at regular intervals is suggested, after cleaning the debris. 


\section{Bridge 5.8:}

- The wing walls also have gaps between stones and the capstones are offset 2" from lower stones. It is recommended to align the stones of abutment and to fill the gaps with epoxy grouting. The gaps and alignment are not a serious threat to the bridge.

- Clean the surface rust and painting is suggested.

- The bent bottom flange of Girder 1 might be a manufacturing mistake. Does not look a failure due to loading, monitoring is suggested. 


\section{Chapter 4 \\ LOAD RATING ANALYSIS}

\subsection{Introduction and Scope}

Steel bridges have the tendency to corrode or develop fatigue cracks and even delaminate under material aging. This deterioration may be in some members or in the entire structure if bridge maintenance is insufficient. Thus, these bridges may reach their ultimate load capacity leading to the collapse of the structure. Over the years, the maximum carload has been increasing, from 220 kips to 263 kips in 1960s and again increased to 286 kips in 2003 (Otter, 2009). Railroads in the US are required to employ periodic inspections and required to maintain record bridge capacities (rating) for the safety of operations, regardless of age, history, and traffic or conditions (AAR Bridge Safety, 2016). Hence, it is imperative that bridge ratings be performed for railroad bridges for their safety.

The analytical steps required to perform a load rating analysis in this report were:

- Measure section properties

- Determine material properties

- Calculate allowable stresses

- Determine appropriate ratings

The purpose of this chapter is to load rate Bridges 1.4 and 5.8 based on the field inspection data presented in Chapter 3 and Appendix F. Ratings are typically expressed in terms of Cooper Eloading for member capacity along with equivalent Cooper E load for equipment. The load rating procedure was based on the guidelines provided in AREMA 2014 Chapter 15, Parts 1 and 7, for rating Bridges 1.4 and 5.8. Assumptions made for rating analysis, analytical procedure followed 
is presented herein, and discussion on rating analyses results are presented in this chapter. Detailed analytical steps are shown in Appendix A, B, C, D.

\subsection{Normal and Maximum Rating}

AREMA Chapter 15, Section 7.3 provides guidance for deriving normal and maximum ratings. Normal rating is the appropriate capacity for day-to-day use of a structure and the maximum rating is the appropriate capacity for occasional use. For both ratings, several factors like specified speed for impact shall be directed by an engineer, and allowable stresses and exerted

loads shall be considered. For normal rating, allowable stresses are based on AREMA Chapter 15, Part 1-Design, Table 15-1-11, whereas, for maximum rating, allowable stresses are allowed to be increased as per AREMA Chapter 15, Table 15-7-1. Table 2 shows allowable stresses for flexure and shear for normal rating. Sections 4.2.1 and 4.2.2 summarizes the calculated allowable stresses for bending and shear for normal and maximum rating of members for Bridges 1.4 and 5.8 . 
Table 2-Allowable stresses for Normal and Maximum Rating

\begin{tabular}{|c|c|c|}
\hline Stress type & Allowable stress normal rating & Allowable stress maximum \\
\hline Flexural tension & $0.55 f_{y}$ & $0.8 \mathrm{f}_{\mathrm{y}}$ \\
\hline Flexural compression & $\begin{array}{c}0.55 f_{y}-\frac{0.55 f_{y}^{2}}{6.3 \pi^{2} E}\left(\frac{l}{r y}\right)^{2} \\
\text { Or (for rolled beams only) } \\
\frac{0.131 \pi E A_{f}}{l d \sqrt{(1+\mu)}} \\
\text { Whichever is larger, but not to } \\
\text { exceed } 0.55 \mathrm{f}_{\mathrm{y}}\end{array}$ & $0.8 \mathrm{f}_{\mathrm{y}}-\frac{0.8 \mathrm{f}_{\mathrm{y}}}{1.8 \times 10^{9}}\left(\frac{\mathrm{l}}{\mathrm{ry}}\right)^{2}$ \\
\hline Shear & $0.35 f_{y}$ & $0.75\left(0.8 f_{y}\right)$ \\
\hline \multicolumn{3}{|c|}{$\begin{array}{l}\mathrm{f}_{\mathrm{y}} \text { - yield strength (psi) } \\
\mathrm{E} \text { - modulus of elasticity (psi) - } \\
1 \text { - distance between point of lateral support for the compression flange (inch) } \\
\mathrm{r}_{\mathrm{y}} \text { - minimum radius of gyration of the compression flange and that portion of the web area } \\
\quad \text { on the compression side of the axis of bending, about an axis in the plane of the } \\
\quad \text { web(inch) } \\
\mathrm{A}_{\mathrm{f}} \text { - area of the smaller flange excluding any portion of the web }\left(\mathrm{inch}^{2}\right) \\
\mathrm{d} \text { - overall depth of the member (inch) } \\
\mu \text { - Poisson's ratio }\end{array}$} \\
\hline
\end{tabular}

\subsubsection{Allowable Stresses - Normal Rating}

The allowable stresses used in normal rating are as per AREMA Chapter 15, Section 7.3.1.1. Allowable stresses were calculated using the procedure described in Section 2.4 and Table 2, which were based on AREMA Chapter 15, Table 15-1-11. Allowable stresses calculated for normal rating are summarized in Table 3, with complete details in the Appendices A through D. 
Table 3-Calculated Allowable Stresses for Rating for Normal Rating

\begin{tabular}{|c|c|c|c|}
\hline \multirow{2}{*}{ Bridge Component } & \multicolumn{3}{|c|}{ Calculated allowable stresses (ksi) } \\
\cline { 2 - 4 } & Shear & Flexural compression & Flexural tension \\
\hline \multicolumn{4}{|c|}{ Bridge 1.4} \\
\hline Girder & 10.50 & 16.15 & 16.50 \\
\hline Floor beam & 10.50 & 16.50 & 16.50 \\
\hline Stringer & 10.50 & 16.50 & 16.50 \\
\hline \multicolumn{5}{|c|}{ Bridge 5.8} \\
\hline Girder & 10.50 & 15.75 & 16.50 \\
\hline
\end{tabular}

\subsubsection{Allowable Stresses - Maximum Rating}

These allowable stresses used in maximum rating normal rating are as per AREMA Chapter 15, Section 7.3.1.2. AREMA Chapter 15, Section 7.3.3.3 and Table15-7-1 provides allowable stresses for maximum rating. Allowable stresses calculated for maximum rating are summarized in Table 4, with complete details in the Appendices A through D.

Table 4-Calculated Allowable Stresses Maximum Rating

\begin{tabular}{|c|c|c|c|}
\hline \multirow{2}{*}{ Bridge Component } & \multicolumn{3}{|c|}{ Calculated allowable stresses (ksi) } \\
\cline { 2 - 4 } & Shear & Flexural compression & Flexural tension \\
\hline \multicolumn{3}{|c|}{ Bridge 1.4} \\
\hline Girder & 18.00 & 24.00 & 24.00 \\
\hline Floor beam & 18.00 & 24.00 & 24.00 \\
\hline Stringer & 18.00 & 24.00 & 24.00 \\
\hline \multicolumn{4}{|c|}{ Bridge 5.8} \\
\hline Girder & 18.00 & 22.91 & 24.00 \\
\hline
\end{tabular}




\subsection{Assumptions to Rate Bridges 1.4 and 5.8}

Several assumptions were taken into account while following above steps to efficiently analyze Bridges 1.4 and 5.8. Since the as-built plans were not available, a detailed set of actual field measurements were taken based on field inspections by WVU-CFC. This inspection revealed noticeable section losses for Bridge 1.4. However, the section losses were away from critical sections affecting shear (web at ends) and flexural (flanges at mid span) capacity of the members. Bridge 5.8 had minor surface corrosion. Hence, section properties at critical locations were calculated ignoring section loss.

\subsubsection{Yield Strength}

The calculations of allowable bending and shear stresses are expressed in terms of the minimum yield strength of the material of the bridge member. In the case of Bridges 1.4 and 5.8, the yield strength of the material used is unknown, as the records of the material are not available. In such scenarios AREMA 2014 Chapter 15, Section 7.3.3.3.a, suggests that "in the absence of test records, the material yield strength shall be taken as $30 \mathrm{ksi}$ for open-hearth or Bessemer steel, 25 ksi for wrought iron, $45 \mathrm{ksi}$ for silicon steel and $50 \mathrm{ksi}$ for nickel steel”. It was determined that the bridges were made of steel, and thus for rating purposed it is conservative to use $30 \mathrm{ksi}$ for yield strength. If rating results determine that the bridges are deficient to carry prescribed equipment, then a coupon testing or non-destructive testing (NDT) may be warranted to obtain the yield strength. A limited review of available resources revealed that such assumption for yield strength is not uncommon (Bollinger, 2015). 


\subsubsection{Loads}

Dead loads, live loads including impact and centrifugal forces are included in the rating analysis. Dead loads (of tracks, ties, guard timber, fastenings and member) in turn give the dead load moments. The live load and dead load moments are found to compute bending moments and stresses leading to the rating of the member using a Cooper E series. The use of specific equipment such as 286k railcar, GP 38 and GP 9, are used in this report by the WVU-CFC to check if the bridge can carry these live loads.

\subsubsection{GP 38 Locomotive}

The GP 38 is a diesel-electric locomotive, currently used on the connecting rail line, as per WVCR. The GP 38 is a general purpose (GP) diesel-electric locomotive manufactured by Electro-Motive Division (EMD) of General Motors (GM), during 1966 - 1977. GP 38 has four axles, each carrying equal weight of the locomotive. GP $38-2$ is a successor model to GP 38 and axle spacing's are same (GATX GP 38, 2016, GATX GP 38-2, 2016, The Diesel Shop, 2016).

Data sheets of GP 38-2 available from various sources were reviewed and found that axle spacing was consistent, but the listed weights varied between 250,000 to 264,800 pounds (approximately 6\% difference) (GATX GP 38-2, 2016 and Diesel unit data book, 2003, and The Diesel Shop, 2016). For rating purposes, herein, the gross rail load was assumed to be 250,000 pounds. Figure 26 shows axle spacing and corresponding axle loads for two GP 38 locomotives connected back to back modeled for rating analysis. 


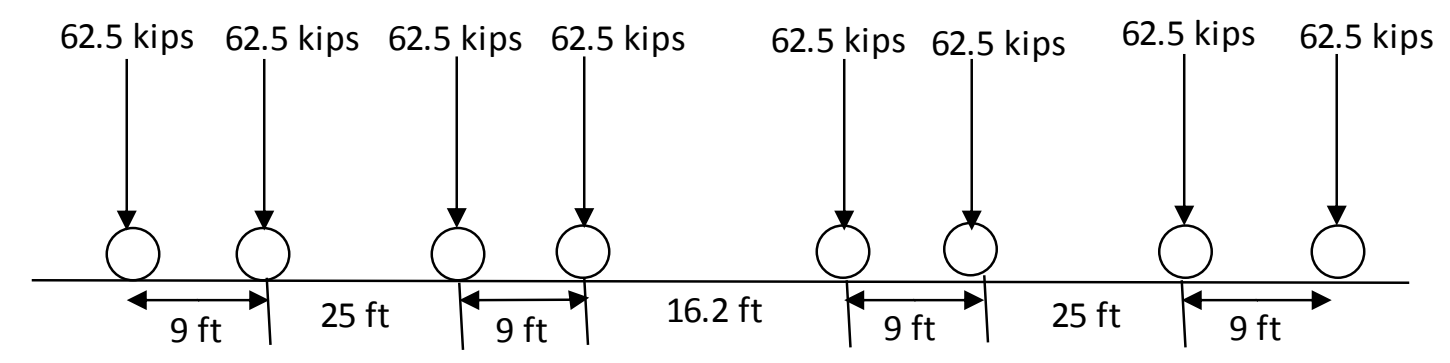

GP-38

Gross Rail Load 250000 Lbs

62.5 Kips Axle weight

Figure 26- Axle Spacing and Axle Weights of GP-38 Locomotive (Adopted from The Diesel Shop, 2016)

\subsubsection{286k Railcar}

A 286k railcar is a standard AAR railcar with gross rail load of 286,000 pounds has four axles with equal loading. Since 2003, 286k railcars have been allowed in unrestricted interchanges (Otter D., 2009). This railcar is used to carry bulk materials like gravel, coal, etc. 286k railcars are found in various length configurations, such as 34.583 feet, 42 feet and 53 feet, measured knuckle-knuckle (WIDOT, 2006, Centerflow, 2016 and Car Library, 2003). Figure 27 shows 42 feet long railcars coupled together that were used for rating analysis herein as they have the shortest distance between cars and thus produce the highest loads (WIDOT, 2006).

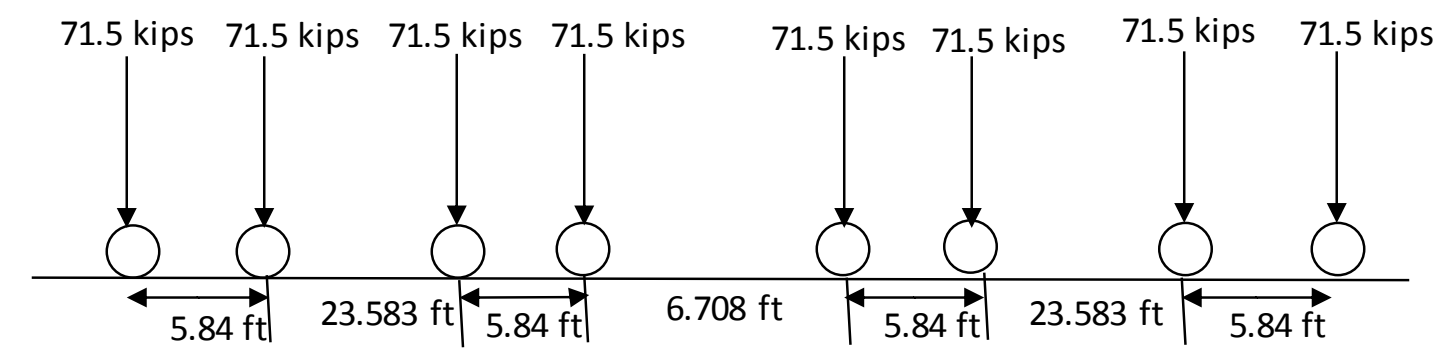

286 Kips Freight Car Gross Rail Load 286000 Lbs 71.5 Kips Axle weight

Figure 27- 286k Railcar Axle Spacing and Axle Weights 


\subsubsection{GP 9 Locomotive}

The GP 9 is a diesel-electric locomotive that also could potentially be used on the WVCR line. The GP 9 is a General Purpose (GP) diesel-electric locomotive manufactured by Electro-Motive Division (EMD) of General Motors (GM), during 1954 - 1963. The GP 9 has four axles, each carrying equal weight of the locomotive. Data sheets of GP 9 available from various sources were reviewed and it was found that axle spacing was consistent but the weights are varying between 246,000 to 254,000 pounds (approximately 3\% difference) (Diesel unit data book, 2003, and The Diesel Shop, 2016). In view of wide weight differences found, locomotive weight was chosen conservatively as 254,000 pounds, for rating purposes, while keeping the axle spacing unchanged. Figure 28 shows axle spacing and corresponding axle loads for two GP 9 locomotives connected back-to-back for rating analysis.

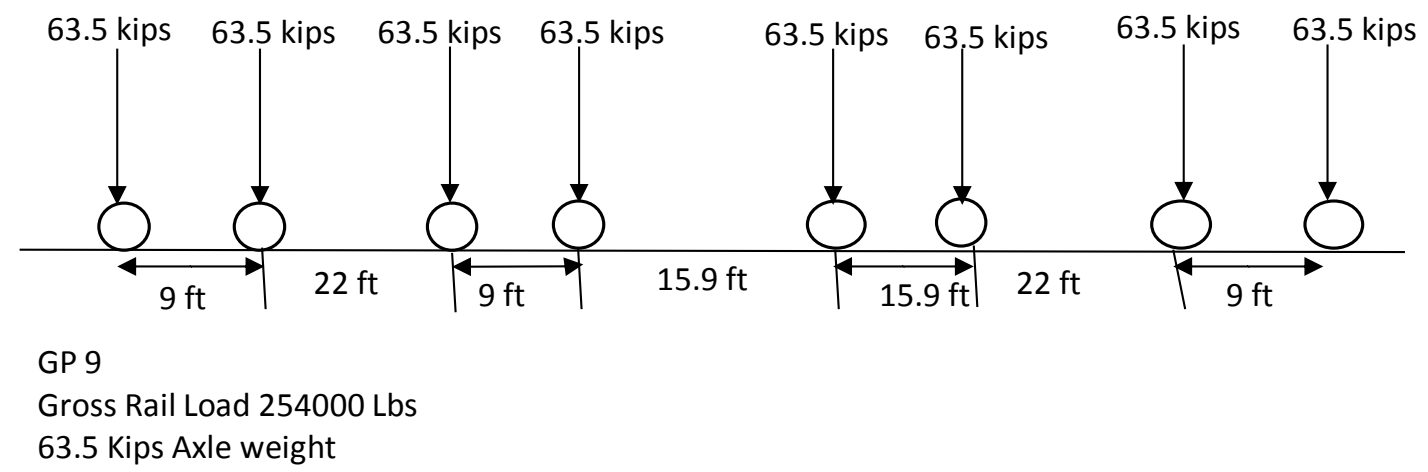

\section{Figure 28- GP-9 Locomotive Axle Spacing and Axle Weights}

Impact factors according to AREMA manual Section 1.3.5 are used for normal rating. Impact factor is allowed to be reduced based on the speed on the line, but the reduction is not applicable to the rocking effect factor. The speed on the line is limited to $10 \mathrm{mph}$ by the WVCR. The impact factor is a multiplier to live load. 


\subsubsection{Fatigue}

According to WVCR historic car loads data from year 1997 to 2005 (Operations, 2005) indicate the maximum freight car loads were 233 units (in the year 1999), which is 0.03 million gross tons assuming 286k railcars. AREMA Chapter 15, Section 7.3.3.2.b suggests that fatigue evaluation is not necessary with detail Category D or lower stress range and if the bridge carries less than 5 million gross ton per year. Bridges 1.4 and 5.8 are riveted construction, hence detail Category D as per AREMA Table 15-1-19. Hence, no fatigue analysis is carried out.

\subsection{Structural Analysis, Load Ratings and Software Tools}

The analyses and load ratings were carried for each load carrying member. The structural unit consisted of simple span plate girders, floor beams and stringers attached to the floor beams in Bridge 1.4 and simple span girders in the case of Bridge 5.8. The ratings were not duplicated for identical members. The structural analysis was done in RISA followed by MS-EXCEL for rating calculations.

\subsubsection{Use of RISA for Analyzing Bridges 1.4 and 5.8}

RISA was used to analyze the bending moments and shears of the entire bridge to determine the controlling members. The basic assumptions of the software tool and its limitations while modeling a member are discussed in brief in this chapter. A 3-D model was used for Bridge 1.4 analysis, while Bridge 5.8 was modeled using a single girder. Bending moments and shear forces obtained from RISA under different live loads considered were exported to MS-EXCEL spreadsheet wherein flexural and shear stresses are calculated. Details and results of RISA and rating calculation are assembled in Appendix A, B, C, D. 


\subsubsection{Through-girder / built-up plate girder}

The through girder or the built-up plate girder is modelled as a beam with thick flanges and a web, as the software limits in modelling a beam with every detail that is seen on the field. A custom beam element was created in RISA using its shape tool that has the same geometric properties as the actual girder. The built-up plate girder shown in Figure 29 is formed using cover plates (to the top and bottom flanges), web plates (above the bearings only) and stiffeners all riveted together. The cross-sectional properties of the plate girder were calculated using the formulas within the Excel spreadsheets by WVU-CFC, which is shown in Appendix A. The bridge with the pinned-roller boundary conditions is shown in Figure 30. The through-girder was analyzed for maximum bending moment and shear, using different live loads (GP 9, Cooper E 10, 286k railcar) moving over the bridge. The maximum bending moment and shear are acquired when the live loads are at a critical section on the beam, which is at mid span for bending and at close to end bearings for shear.

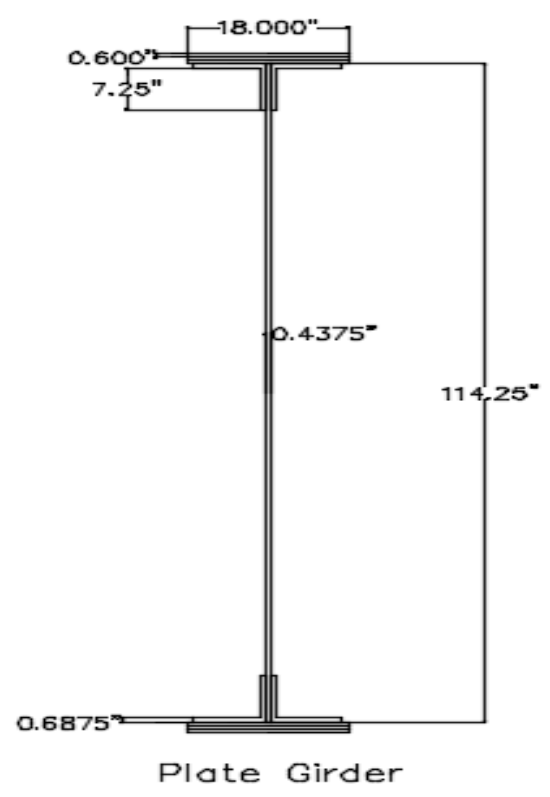

Figure 29- Through Girder or Built-up Plate Girder (Field Representation With Cover Plates, Stiffeners and Web plate) 


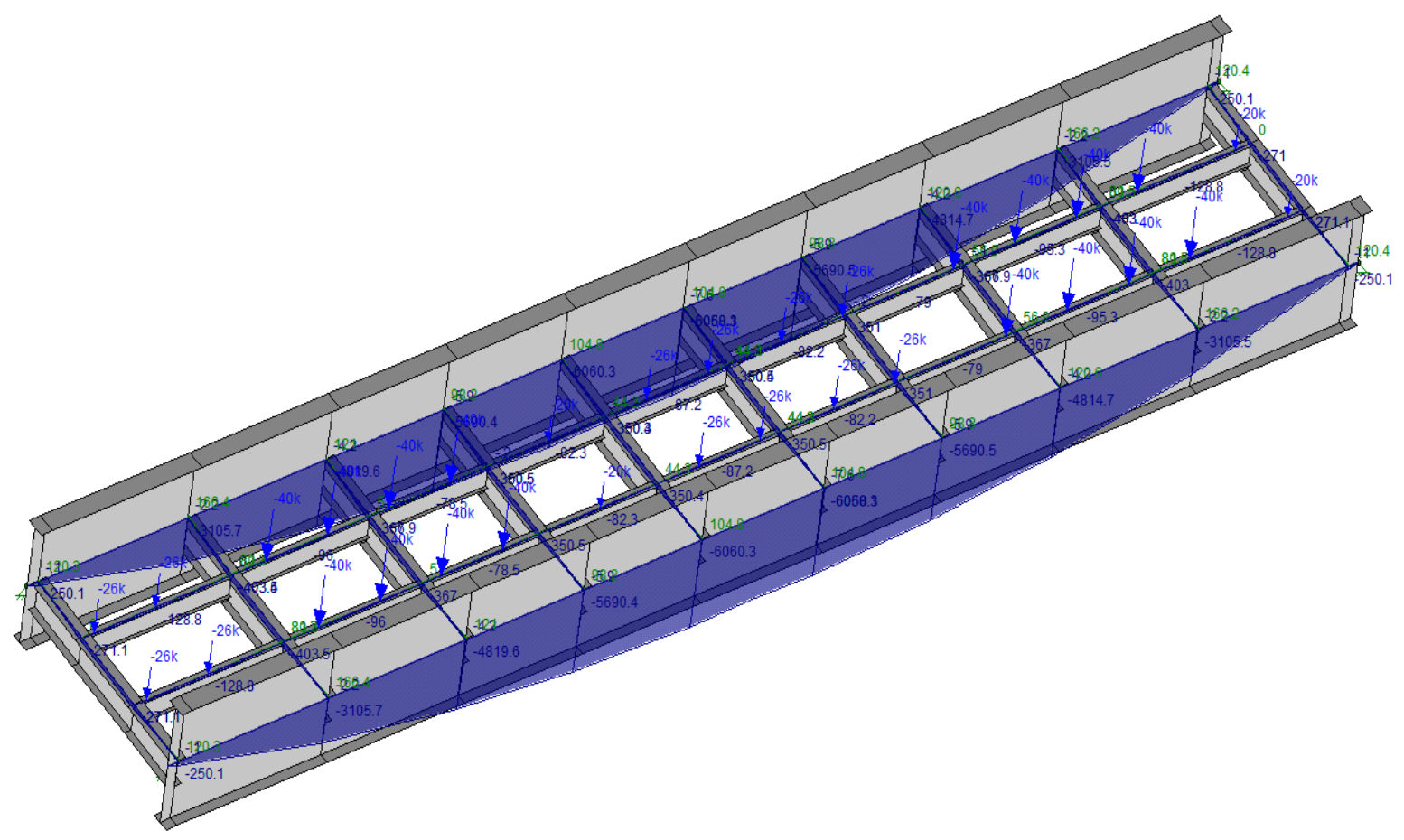

Figure 30- Through Girder Designed in RISA, as a Beam With Thick flanges and Web and Pinned-Pinned Boundary Condition. Live Load - Cooper E 80, Live Load Moment 6060.3 Kip-ft. (No Impact Factor used)

\subsubsection{Floor Beam}

The floor beam analysis uses the same model as through girder. The shape properties of the beam element used in the model for floor beam is shown in Figure 31. Axle loads of the locomotives used were divided into two halves allowing it to move on two stringers to obtain maximum live load moments and shears as shown in Figure 32 and Figure 33. The maximum shear and maximum bending required for load rating calculations of the floor beam were obtained from RISA analysis. A summary of maximum bending moment and shear force obtained for RISA analysis are presented in Appendix A, B, C, D. 


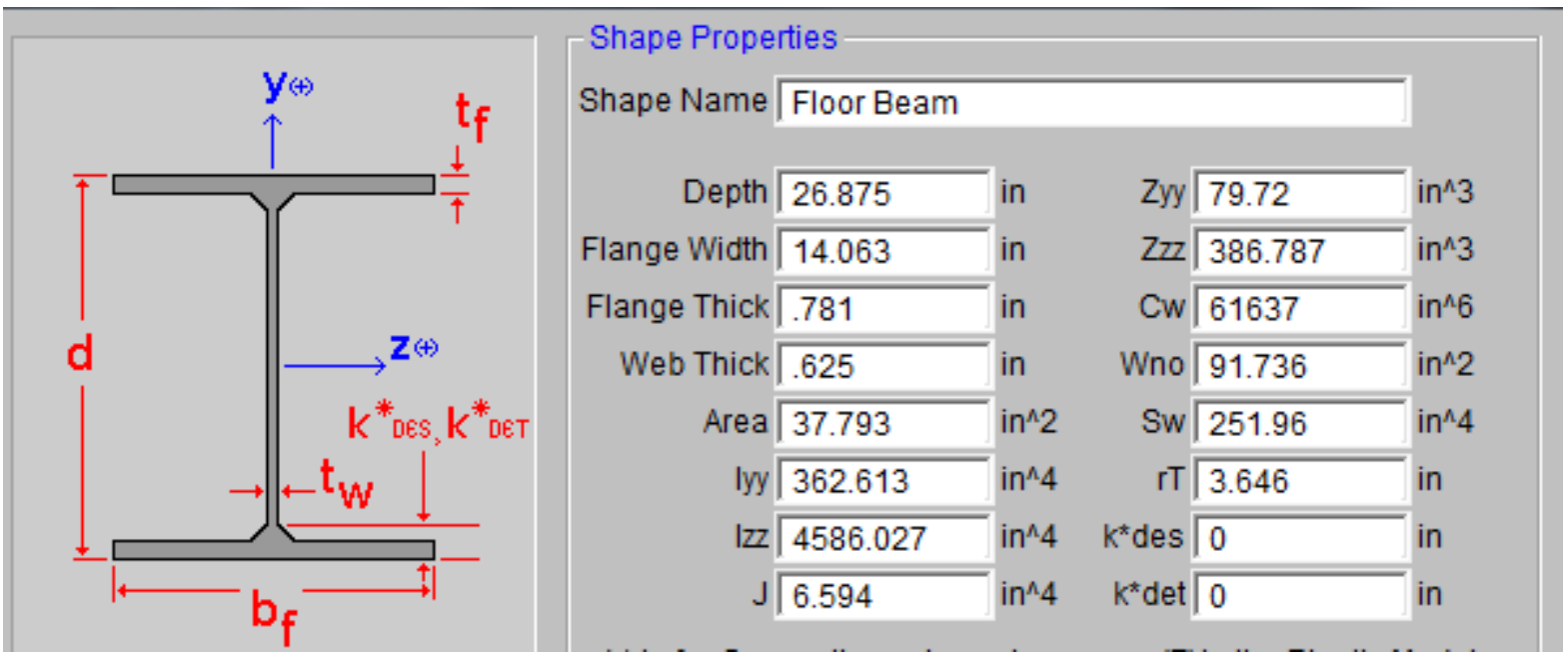

Figure 31- Shape Properties, Floor Beam

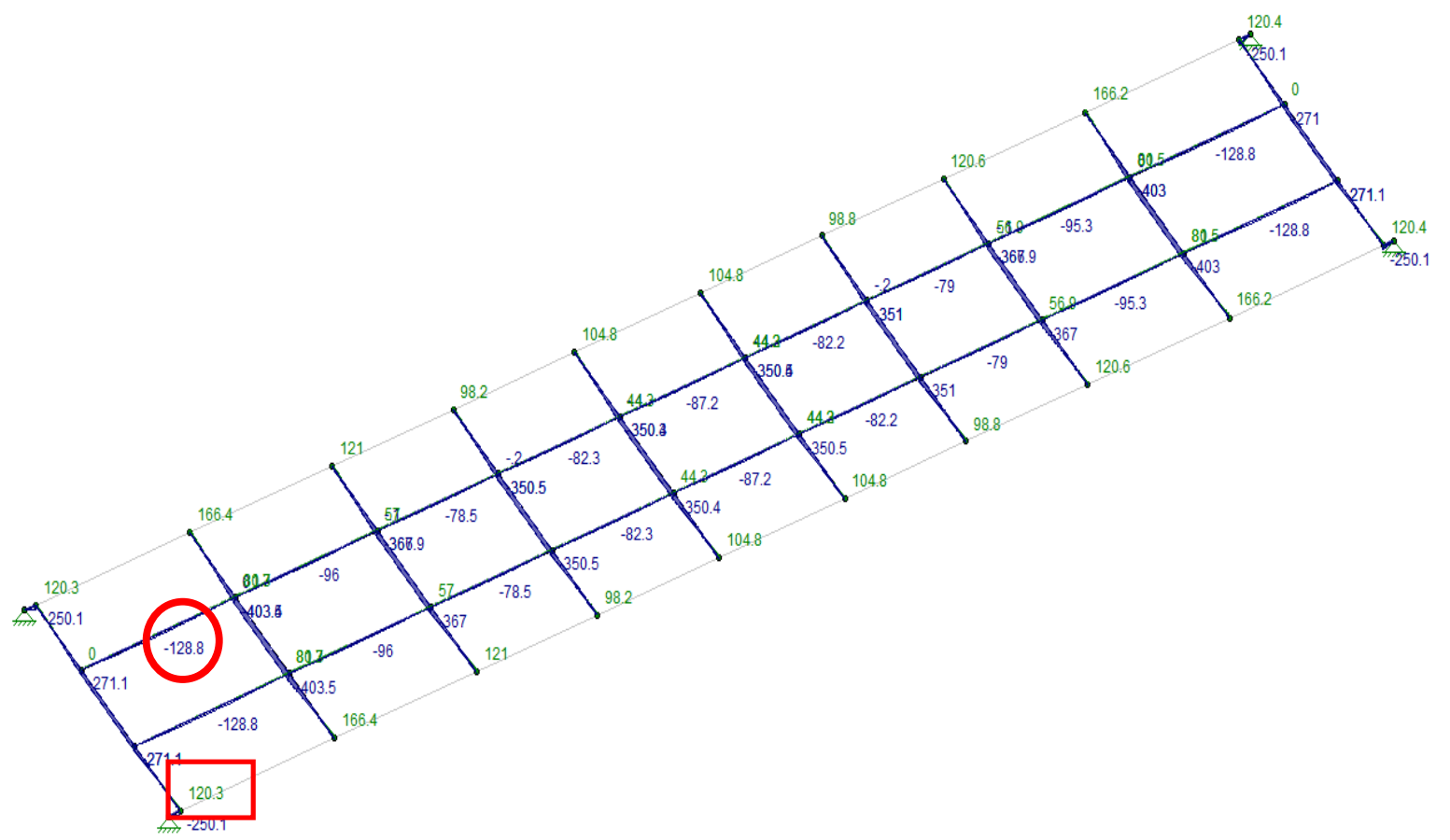

Figure 32- Rendered Model Consisting of Floor Beam, Stringers and Girders With Load Passing Over The Bridge Model Obtaining a Maximum Bending Moment of 403.5 ft-kips (No Impact Factor Used) for Floor Beam (Circle) and $128.8 \mathrm{ft}-k i p s$ (No Impact Factor Used) For Stringer (Rectangle) 


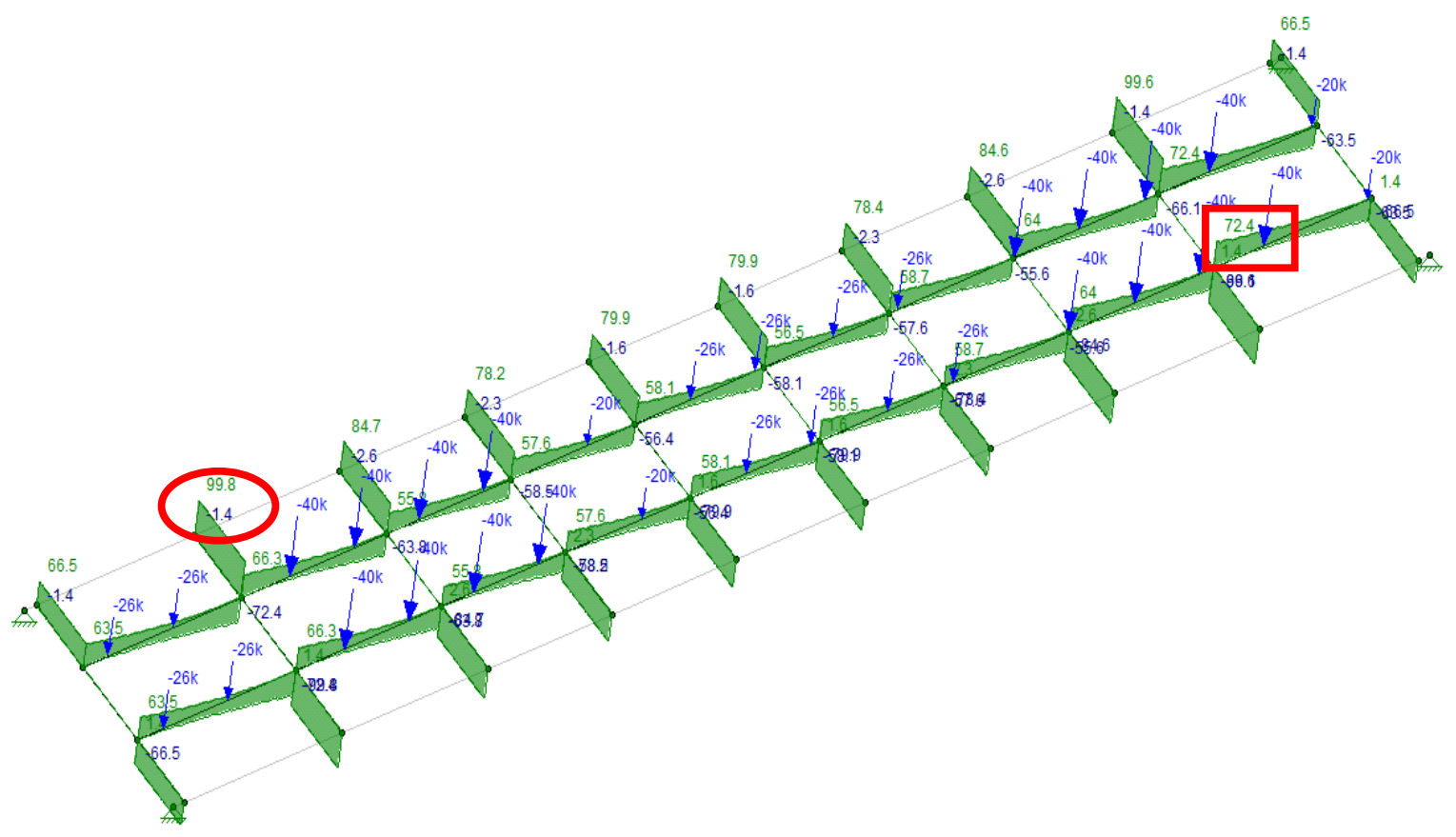

Figure 33- Rendered Model Consisting of Floor Beam, Stringers and Girders With Load Passing Over The Bridge Model Obtaining a Maximum Shear of 99.8 ft.-kips Floor Beam (circle) and 72.4 kips For Stringer (Rectangle)

\subsubsection{Stringers Bridge 1.4}

An American Standard Section S20x65.4, which was available in the AISC historic database was used as the beam element to represent the stringer. The shape properties of the stringer used in RISA is shown in Figure 34. The lengths of stingers vary as floor beam spacing varies, as shown in the Table 5. Maximum shear and moment occurs at the longest stringers at the ends of the bridge. 

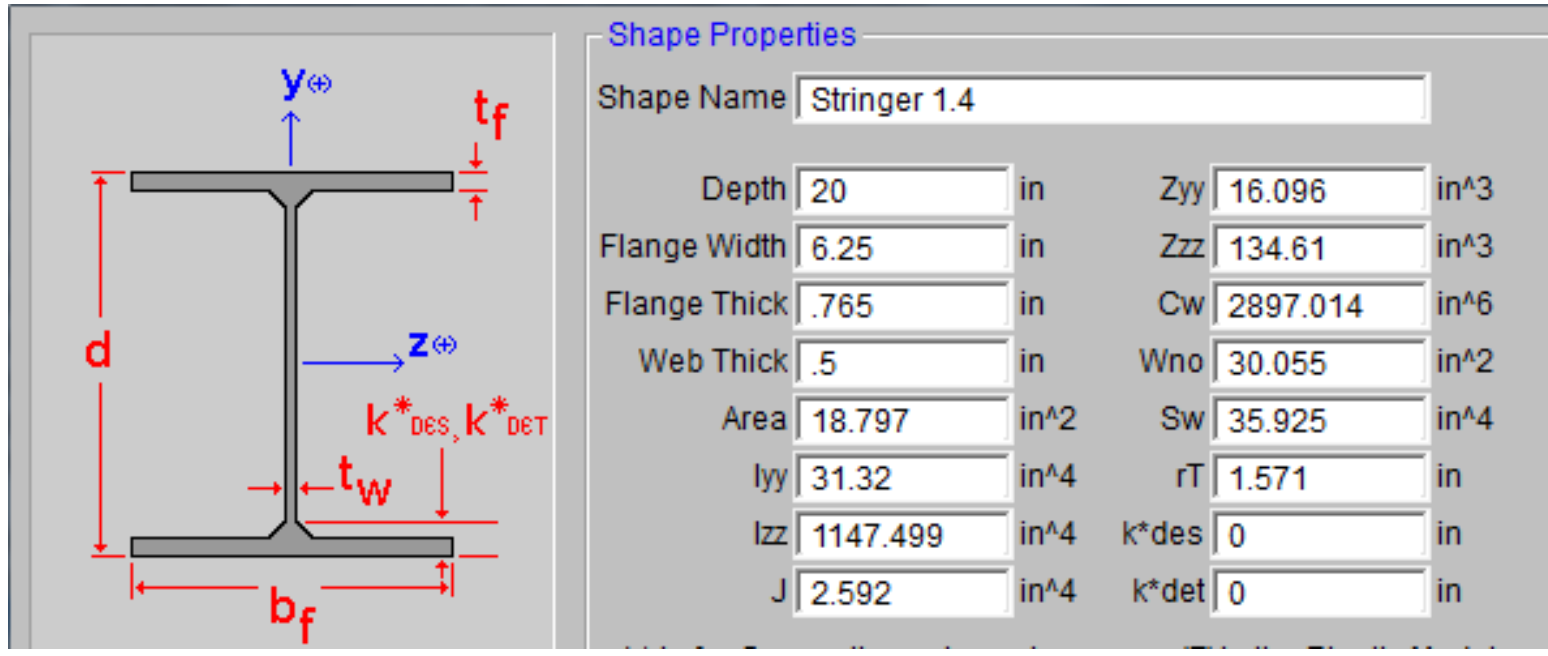

Figure 34- Shape Properties of Stringer of Bridge No. 1.4 Used in RISA

Table 5- Table Showing Distances Between Floor Beams in Span 1, Bridge 1.4

\begin{tabular}{|c|c|}
\hline Floor beam 1 & $1.685 \mathrm{ft}$ from support \\
\hline Floor beam 1- Floor beam 2 & $12.208 \mathrm{ft}$. \\
\hline Floor beam 2- Floor beam 3 & $11.208 \mathrm{ft}$. \\
\hline Floor beam 3- Floor beam 4 & $9.625 \mathrm{ft}$. \\
\hline Floor beam 4- Floor beam 5 & $9.625 \mathrm{ft}$. \\
\hline Floor beam 5- Floor beam 6 & $9.958 \mathrm{ft}$. \\
\hline Floor beam 6- Floor beam 7 & $9.625 \mathrm{ft}$. \\
\hline Floor beam 7- Floor beam 8 & $9.583 \mathrm{ft}$. \\
\hline Floor beam 8- Floor beam 9 & $11.25 \mathrm{ft}$. \\
\hline Floor beam 9- Floor beam 10 & $12.208 \mathrm{ft}$. \\
\hline
\end{tabular}

\subsubsection{Bridge 5.8 Girders}

The girder of bridge 5.8 is a built-up member with angles attached to a web plate. The angles have two legs which are $4 ", 6.125$ " and 0.46875 " thick. The 4 " leg is attached to the web for all the four angles and the 6.125 " legs acting as flanges at top and bottom. The web plate is 30.5 " in 
depth and 0.375 " thick. A section which has an area and moment of inertia equal to the original member was created using the RISA custom element tool. Figure 35 shows a rendered view of the model of Bridge 5.8 girder in RISA with GP 38 moving loads.

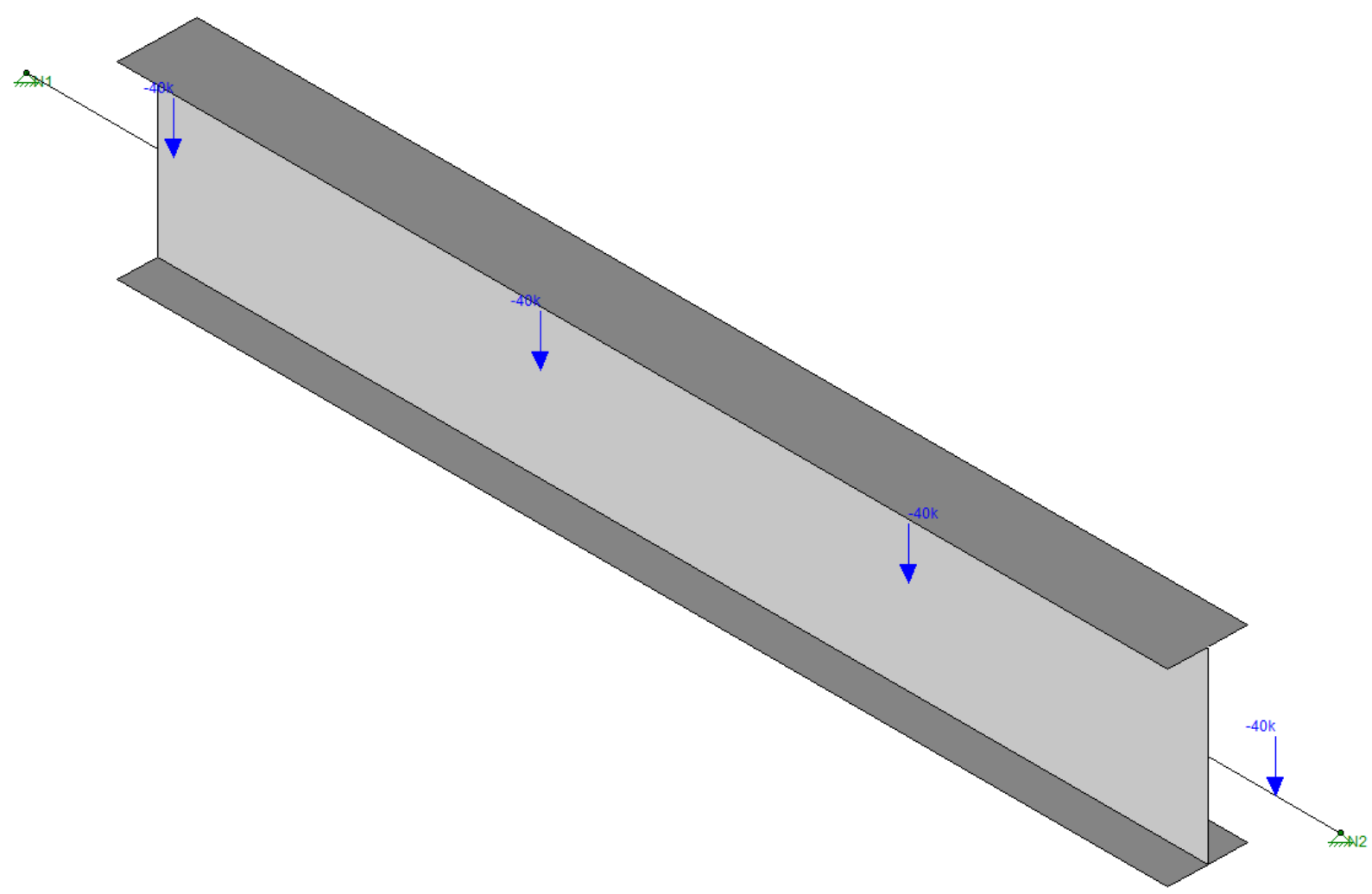

Figure 35- Showing Rendered Model of Girder of Bridge No. 5.8 in RISA With Cooper E 80-Wheel Load Moving Over The Stringer to Get a Maximum Bending Moment and Shear

\subsubsection{RISA Analysis Summary}

RISA analysis was performed on Bridges 1.4 and 5.8, for live loads including Cooper E 80, GP 38, GP 9, WM 82 locomotive, 286k railcar and the hi-rail dump truck. The maximum bending moment and shear forces from the RISA analysis were inputted into MS-EXCEL spreadsheets to calculate ratings for bridge members and equivalent Cooper rating for equipment. The calculation of moment of inertia of the plate girder from Bridge 1.4 is shown in Figure 36. 
Induced stresses are determined for the calculated dead load, and each considered live load.

Table 6 and Table 7 summarizes maximum bending moment and shear forces for the members

for Bridges 1.4 and 5.8.

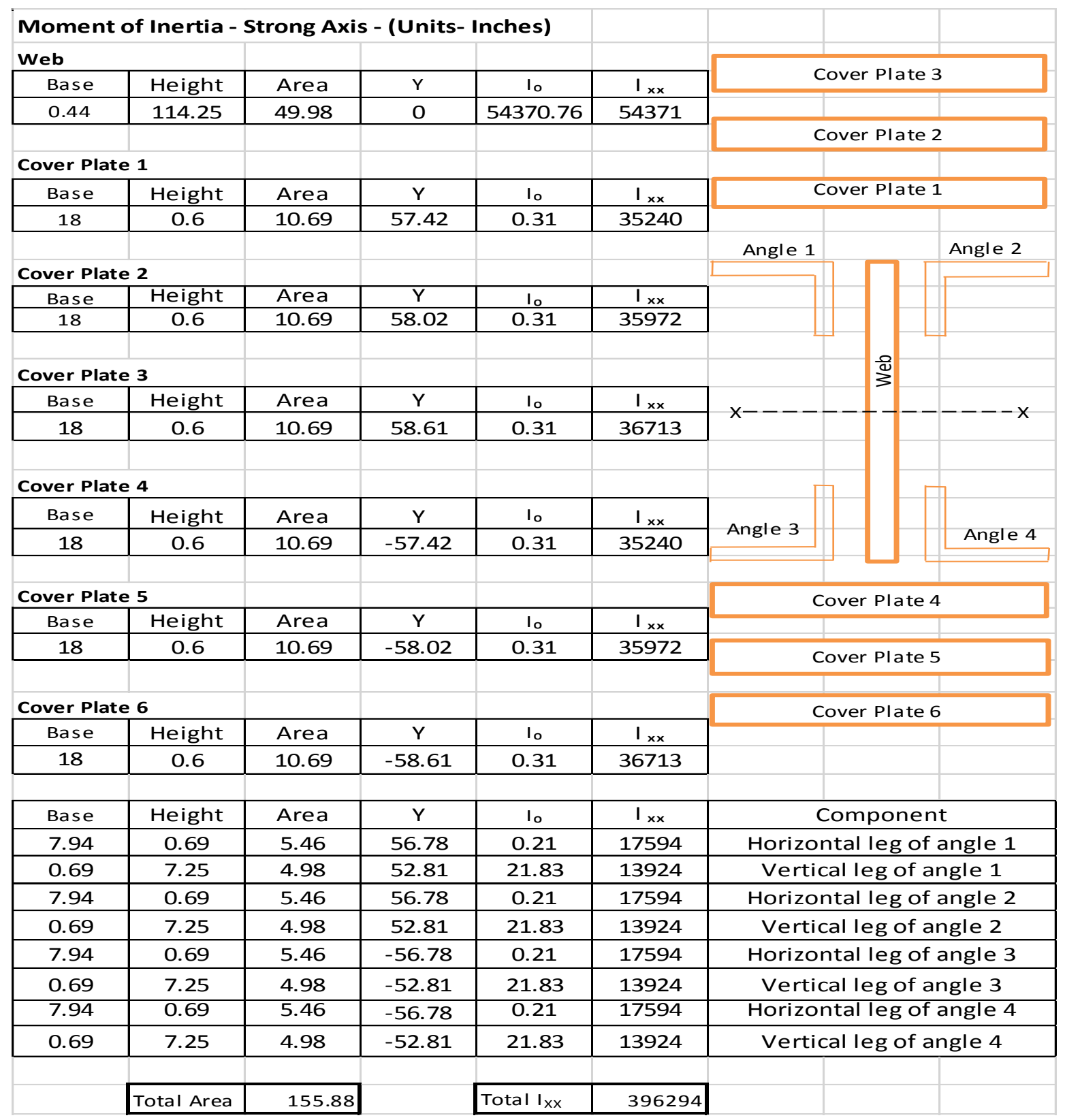

Figure 36- Shape Properties of The Section Built-up in RISA For The Analysis, Obtaining a Total Area and moment of Inertia 
Table 6-Summary of Maximum Bending Moment and Shear Forces For Bridge 1.4

\begin{tabular}{|c|l|c|c|c|c|c|}
\hline \multirow{2}{*}{$\begin{array}{c}\text { Through } \\
\text { Girder }\end{array}$} & Load effect & $\begin{array}{c}\text { Cooper E } \\
80 \text { (no } \\
\text { impact) }\end{array}$ & $286 \mathrm{~K}$ & GP 38 & GP 9 & WM 82 \\
\cline { 2 - 7 } & $\begin{array}{l}\text { Maximum bending } \\
\text { moment (ft-kip) }\end{array}$ & 6051.9 & 4094.2 & 2571.9 & 2676.7 & 2437.7 \\
\cline { 2 - 8 } & Shear (kip) & 285.9 & 200.5 & 122.2 & 126.9 & 115.8 \\
\hline \multirow{2}{*}{$\begin{array}{l}\text { Floor } \\
\text { beam }\end{array}$} & $\begin{array}{l}\text { Maximum bending } \\
\text { moment (ft-kip) }\end{array}$ & 403.5 & 302.8 & 172.3 & 175.6 & 162.3 \\
\cline { 2 - 8 } & Shear (kip) & 99.8 & 75 & 43.4 & 44.1 & 40.3 \\
\hline \multirow{2}{*}{ Stringer } & $\begin{array}{l}\text { Maximum bending } \\
\text { moment (ft-kip) }\end{array}$ & 128.8 & 98.04 & 76.56 & 79.5 & 72.5 \\
\cline { 2 - 8 } & Shear (kip) & 72.4 & 55.7 & 38.3 & 39.7 & 36.3 \\
\hline
\end{tabular}

Table 7-Summary of Maximum Bending Moment and Shear Forces For Bridge 5.8

\begin{tabular}{|c|c|c|c|c|c|}
\hline Load effect & $\begin{array}{c}\text { Cooper E 80 } \\
\text { (no impact) }\end{array}$ & 286k & GP 38 & GP 9 & WM 82 \\
\hline $\begin{array}{c}\text { Maximum } \\
\text { Bending moment } \\
\text { (ft-kip) }\end{array}$ & 335 & 254.6 & 138.67 & 140.89 & 128.69 \\
\hline $\begin{array}{c}\text { Maximum Shear } \\
\text { (kip) }\end{array}$ & 92.49 & 70.25 & 46.5 & 47.16 & 42.75 \\
\hline
\end{tabular}

\subsection{Rating Analysis Results}

Analysis results in conjunction with calculations in MS-EXCEL spreadsheet is used calculate member rating and equipment rating. The formulas to compute the rating factor in Cooper $\mathrm{E}$ terms and the equivalent Cooper E loadings are shown below. 
Rating Factor $=\mathrm{RF}_{\mathrm{n}} \operatorname{OrRF}_{\mathrm{m}}=\frac{\text { AllowableStress }\left(F_{b n}, F_{v n} \text { or } F_{b m}, F_{v m}\right)-\operatorname{Dead} \operatorname{Load} \operatorname{Stress}\left(F_{D L}\right)}{\text { Live Load Stress }\left(f_{L L}, f_{V L}\right)} * 80$

Equivalent Coper E-load $=\quad \frac{\text { Equipment (286 Kips, GP 38, GP 9, WM 82) Live Load Moment or Shear }}{E 80 \text { Live Load Moment or Shear }} * 80$

Table 8 and Table 9 shows the bridge normal and maximum ratings for $10 \mathrm{mph}$ speed along with equivalent Cooper E loads for the equipment.

Table 8-Load Rating Results of Bridge 1.4 Members

\begin{tabular}{|c|c|c|c|c|c|c|c|}
\hline \multirow{4}{*}{$\begin{array}{c}\text { Through } \\
\text { Girder }\end{array}$} & \multirow{4}{*}{$\begin{array}{l}\text { LOAD EFFECT } \\
\text { Bending } \\
\text { Shear }\end{array}$} & \multicolumn{2}{|c|}{ Cooper E rating } & \multicolumn{4}{|c|}{ Equivalent Cooper E load } \\
\hline & & Normal & Maximum & $286 \mathrm{k}$ & GP 38 & GP 9 & $\begin{array}{c}\text { WM } \\
82 \\
\end{array}$ \\
\hline & & E 83.0 & E 129.5 & E 54.05 & E 33.9 & E 35.3 & E 32.1 \\
\hline & & E 106.0 & E 189.1 & E 56.19 & E 34.25 & E35.5 & E 32.4 \\
\hline \multirow{2}{*}{$\begin{array}{l}\text { Floor } \\
\text { beam }\end{array}$} & \multirow{2}{*}{$\begin{array}{l}\text { Bending } \\
\text { Shear }\end{array}$} & E 68.7 & E 101.8 & E 60.03 & E 34.1 & E 34.8 & E 32.1 \\
\hline & & E 100.5 & E 174.8 & E 60.12 & E 34.8 & E 35.3 & E 32.3 \\
\hline \multirow{2}{*}{$\begin{array}{c}\text { Stringer } \\
\text { rating }\end{array}$} & \multirow{2}{*}{$\begin{array}{l}\text { Bending } \\
\text { Shear }\end{array}$} & E 76.2 & E 111.0 & E 60.9 & E 47.5 & E 49.3 & E 45.0 \\
\hline & & E 81.7 & E 141.5 & E 61.5 & E 42.3 & E 43.9 & E 40.1 \\
\hline
\end{tabular}

Table 9-Load Rating Results of Bridge 5.8 Members

\begin{tabular}{|l|c|c|c|c|c|c|}
\hline & \multicolumn{2}{|c|}{ Cooper E Rating } & \multicolumn{3}{c|}{ Equivalent Cooper E load } \\
\hline Load effect & Normal & Maximum & $286 \mathrm{k}$ & GP 38 & GP 9 & $\begin{array}{c}\text { WM } \\
82\end{array}$ \\
\hline Bending & E 71.1 & E 105.0 & E 60.8 & E 33.12 & E 33.6 & E 30.7 \\
\hline Shear & E 77.9 & E 135.8 & E 60.76 & E 40.22 & E 40.7 & E 36.9 \\
\hline
\end{tabular}

As the equivalent Cooper E loads do not exceed the Cooper E normal rating, all equipment listed can safely cross both Bridges 1.4 and 5.8 traveling at $10 \mathrm{mph}$. 


\subsection{Rating Analysis Summary}

The detailed procedure followed for rating of bridge members and equipment was presented. As noted in Section 4.4, both Bridges 1.4 and 5.8 have capacity to support the 286k railcar, GP 38, GP 9 and WM 82 locomotives at $10 \mathrm{mph}$ under normal rating criteria. Fatigue is not a concern as the amount of traffic is less than the AREMA threshold for this short-line railroad.

For Bridge 1.4 the minimum normal rating for bending is $\mathrm{E} 68.7$ for the floor beam, while maximum equipment load for bending is E 60.03 for the 286k car. For Bridge 5.8, bridge capacity is $\mathrm{E}$ 71.1. The above rating analyses were based on the inspections as described in Chapter 3. Further, analyses results used for rating are compared with field testing results in Chapter 5. 


\section{Chapter 5 \\ FIELD TESTING}

\subsection{Field Testing}

Analytical procedures may not represent the true bridge capacity or its behavior because of inadequate representation of true boundary conditions or connector response or lack of understanding of material behavior. In addition, there are adjustments in bearing restraint effects and longitudinal live load distributions. Hence, to determine a more accurate safe capacity of a bridge, field testing was carried out. Field testing measures the response of a structure under load (Barker, 1999). The bending and shear strains along with deflections of main members are obtained typically using strain gages. The strain gage data was compared with the results from load rating analyses using software models and hand calculations.

Additional information about strain gage installation for field testing, field test procedures and a brief discussion about comparison of our field testing results are given below.

\subsubsection{Strain Gage Installation}

During the field inspections, key locations were chosen and marked to install the strain gages. A total of 13 strain gages ( 8 uniaxial, 3 shear and 2 compression strain gages) were installed on Bridge 1.4 and total of 6 strain gages (4 shear and 2 uniaxial strain gages) on Bridge 5.8. The strain gages per bridge are shown below in Table 10. The strain gages designation is shown in Figure 37. 
Table 10- Number of Strain Gages per Bridge with Designated Locations (Gages No. 5 and 13 of Bridge 1.4 are Bad Gages)

\begin{tabular}{|c|c|c|}
\hline Gage \# & Bridge No. 1.4 & Bridge No. 5.8 \\
\hline 1 & S-S1n-Fs & S-S1n-G1e \\
\hline 2 & S-S1n-G2e & S-S1n-G2w \\
\hline 3 & C-S1n-G2e & S-S1o-G1e \\
\hline 4 & C-S1n-G2w & S-S1o-G2w \\
\hline$-5---$ & - S-S1e-G2e- - & B-S1c-G1b \\
\hline 6 & B-S1c-G1t & B-S1c-G2b \\
\hline 7 & B-S1c-G1b & \\
\hline 8 & B-S1c-G2t & \\
\hline 9 & B-S1c-G2b & \\
\hline 10 & B-S1c-S1c & \\
\hline 11 & B-S1c-Fc & \\
\hline$-12----$ B-S2c-G1t- - & \\
\hline 13 & B-S2c-G2t & \\
\hline
\end{tabular}

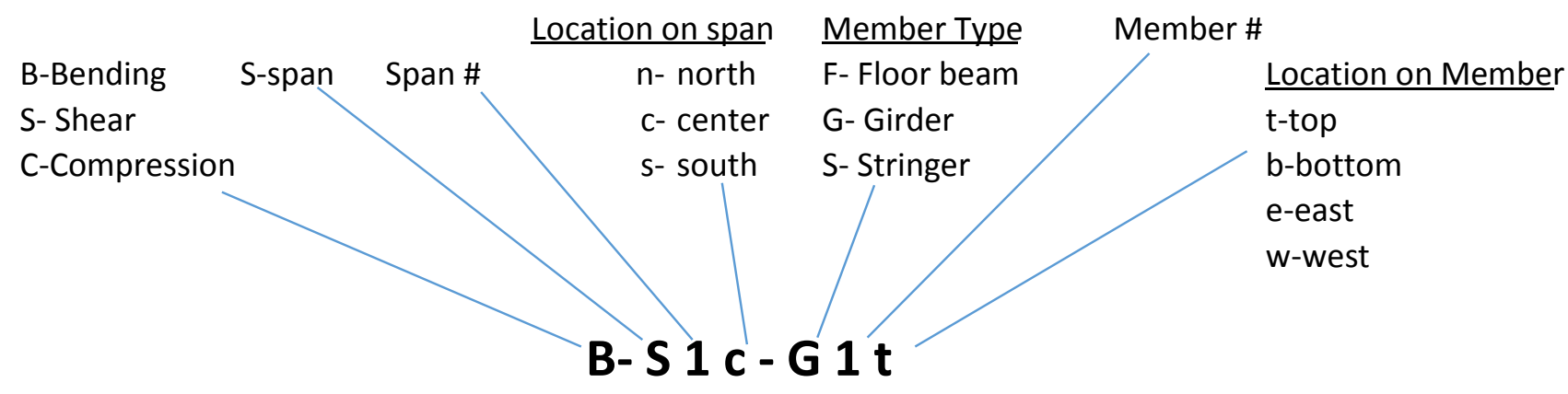

Designation chart prepared by Mark Skidmore (WVU-CFC)

\section{Figure 37- Designation of The Strain Gages}

Plate girders 1 and 2 of Bridge 1.4 have the bending strain gages installed on top and bottom of girders, along with the longitudinal axis at mid span. The plate girders 3 and 4 have strain gage installed only on the top due lack of access to the bottom. The shear strain gage were installed on the web of plate girder 2, 36 inches away from the support and on the end of a floor beam. Two gages were installed on the interior and exterior vertical legs of the bottom flange of the plate girder 2, to check if the angles were adequate to resist the compression from bearing. The interior 
vertical leg of the bottom flange section loss due to corrosion. Bridge 5.8 has bending strain gages at the bottom of both the girders at mid span and shear strain gages installed close to the support and 30 inches away from the support on both the girders 1 and 2. Figure 38, Figure 39, Figure 40 show the locations of the gages on the bridges. LVDT's (Linear Variable Differential Transducers) were installed at the center of span of plate girders 1 and 2 on span 1 and to the floor beam, located center of span 1 . These locations were chosen to get the maximum effect of deflection. Two photo electric sensors were placed on the track, in order to locate the vehicle on the bridge and to record when the axles crossed the designated points on the structure.

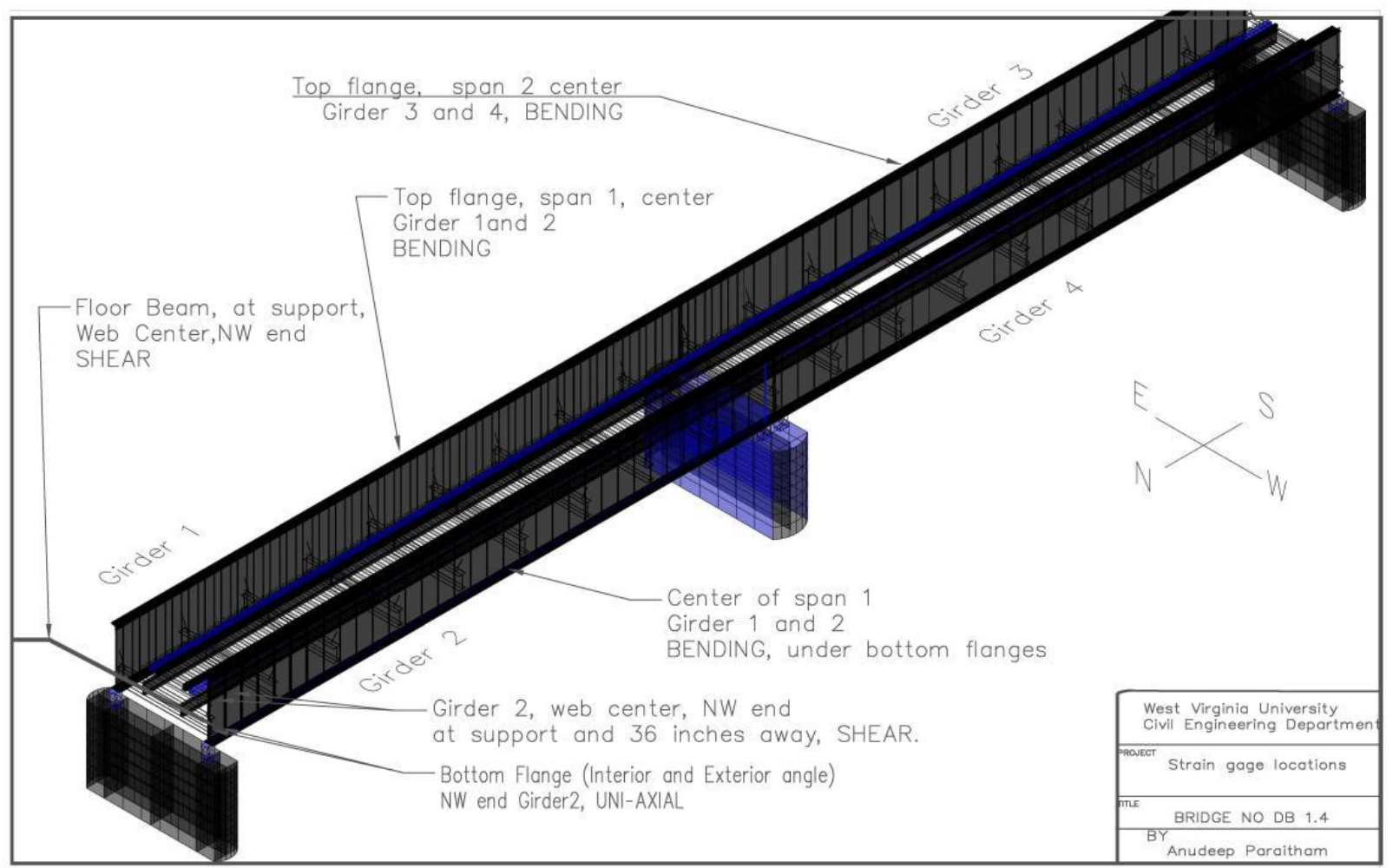

Figure 38- AUTOCAD- 3D Drawing Showing the Location of The Strain Gages on Bridge No. 1.4 


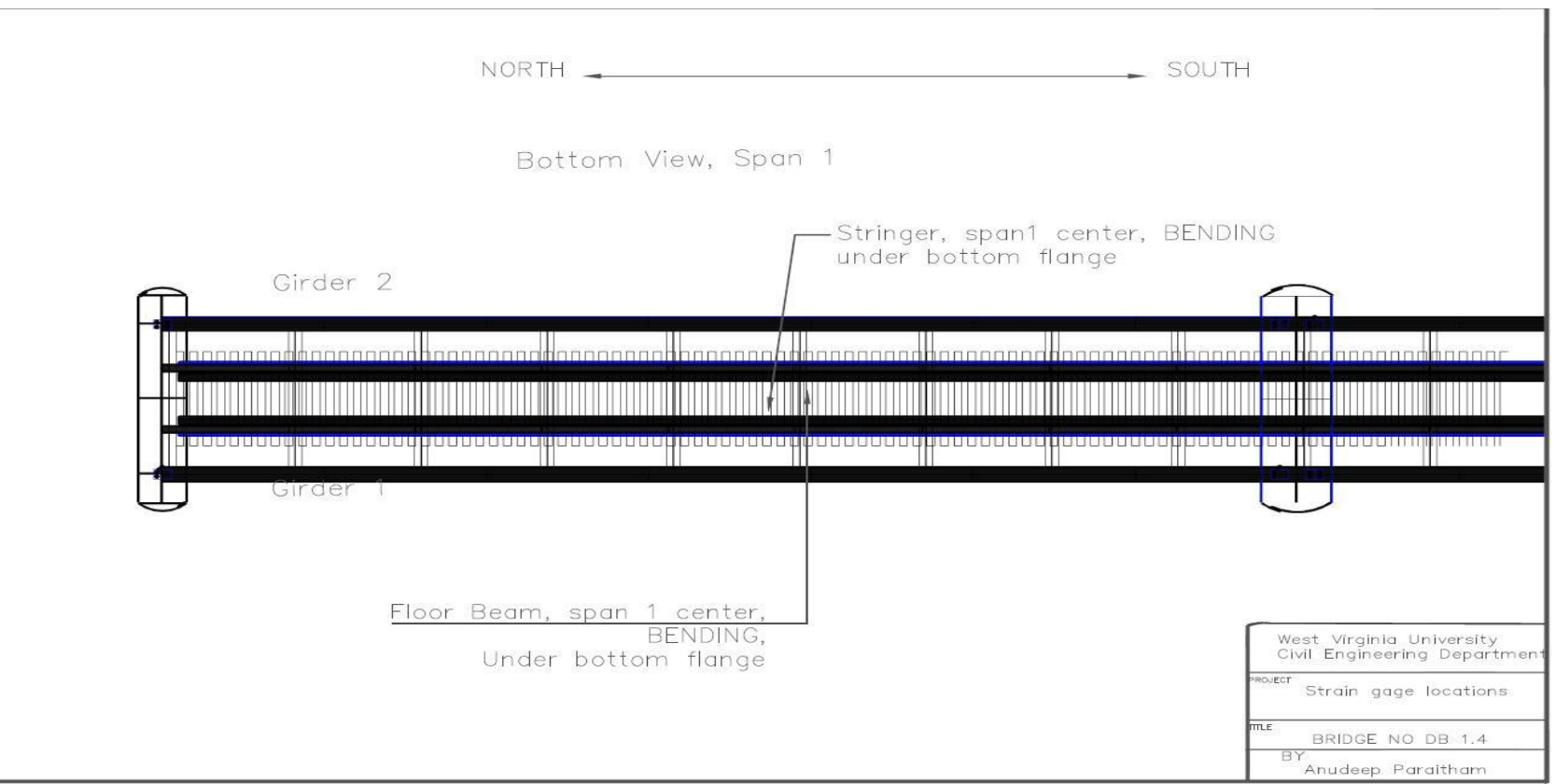

Figure 39- Bottom View of The Bridge No. 1.4 (Span 1), Showing Location of strain Gages on Floor Beam and Stringer.

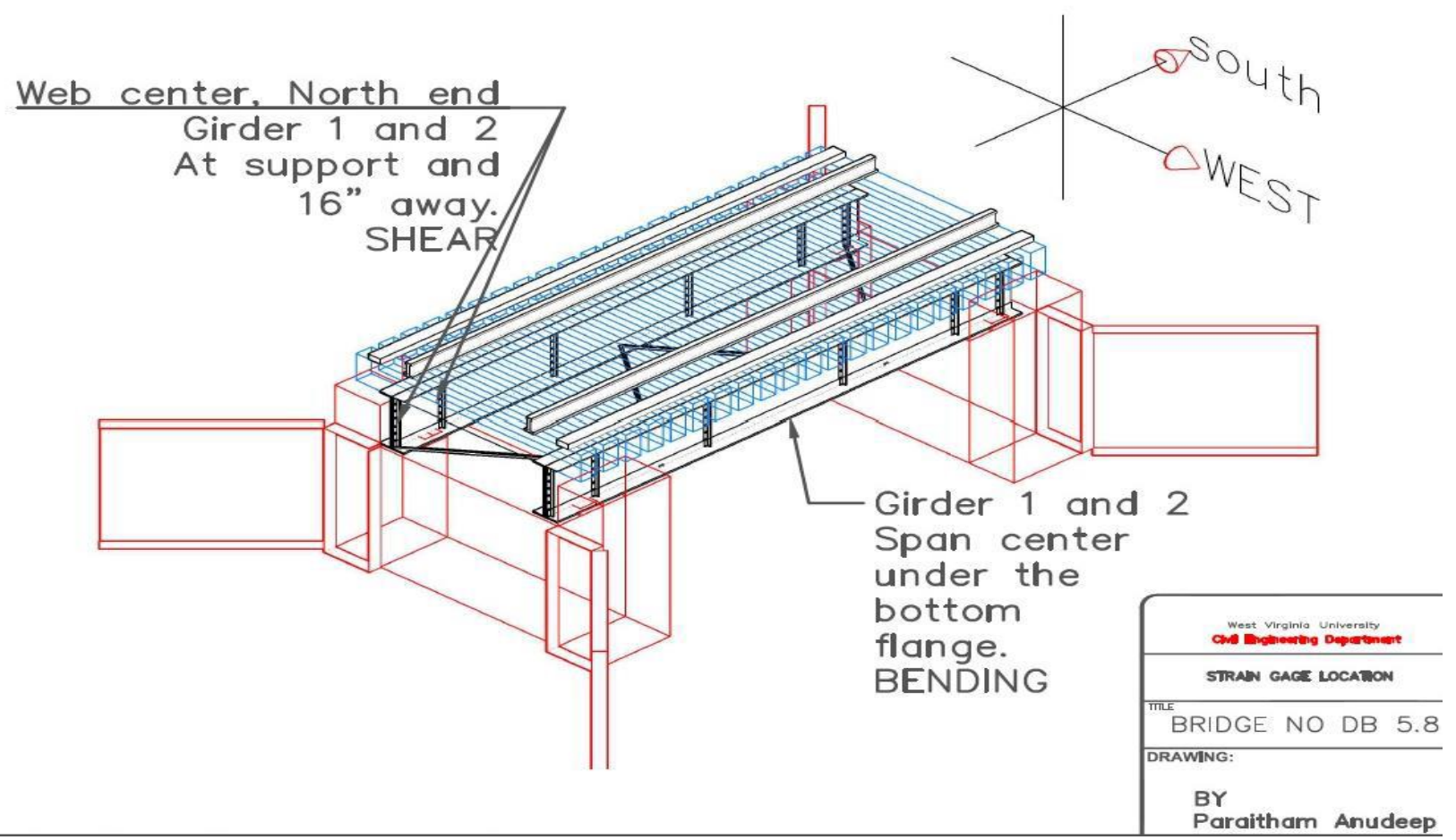

Figure 40- Bridge No. 5.8, Location of All Strain Gages. 


\subsubsection{Equipment Used for Testing}

\subsubsection{Hi-rail Dump Truck}

WVDOT provided hi-rail dump truck for field testing, as there were operational difficulties mobilizing a locomotive, particularly bridge 5.8. A typical dump truck for highways, used for earth/gravel moving, is equipped with steel wheels to run on rails. Steel wheels are lowered and raised with hydraulics. While running on track rails, steel wheels are used for rolling while traction provided rubber tires that are in contact with the rail. This type vehicle is typically referred as hi-rail mounted dump truck (Figure 41).

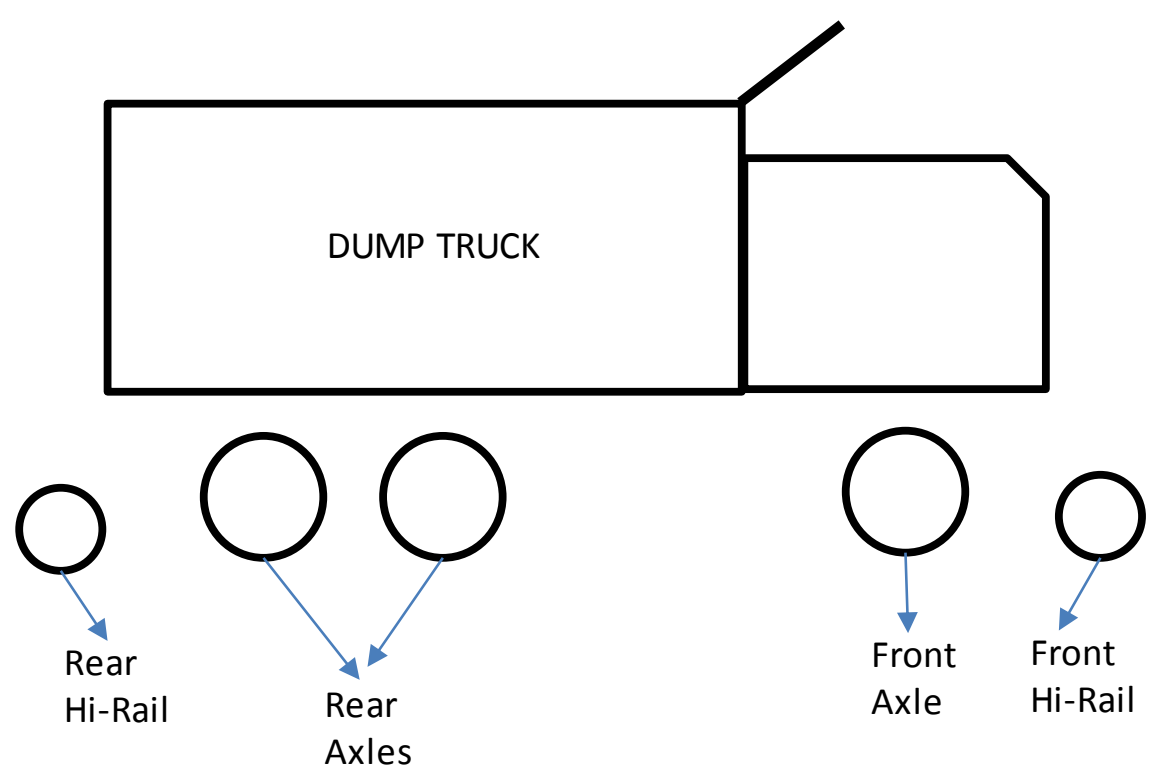

Figure 41 Schematic Representation of Hi-rail Dump Truck

The Hi-rail dump truck was used at both bridges 1.4 and 5.8 on two separate days. Total weight of the dump truck was found to be 66,480 pounds and 64,860 pounds on respective days of field testing. The axle load distribution was unknown prior testing. Based on the testing results on bridge 5.8, it was determined that the average rear axle is $69.1 \%$ of the total weight of the truck 
Load analysis was carried out based on the axle weight and spacing shown in Figure 42 and the field test results are discussed in Chapter 5, along with the analytical data comparisons.

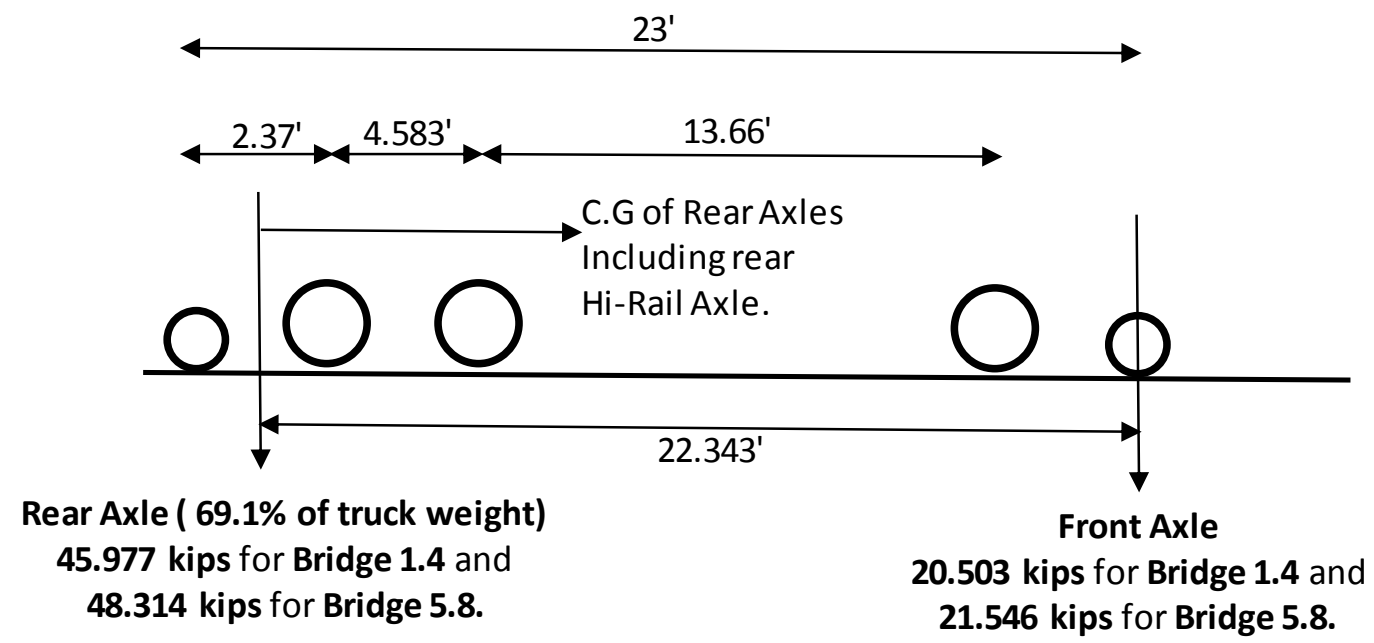

Figure 42 Axle spacing and Axle Weights of Hi-rail Dump Truck

\subsubsection{WM 82 Locomotive}

Western Maryland 82 (WM 82) locomotive was used for field testing. As per data provided by WCVR, WM 82 is a Branch Line 2 (BL-2) series model built in October 1948 by EMD General Motors Electro-Motive Division (EMD). Axle loading and axle spacing data are represented in Figure 43. A single WM82 car was used in the analytical analysis for comparison of field testing results (Strains). For rating purposes, two WM 82 cars were used to obtain maximum bending moment and shear. 


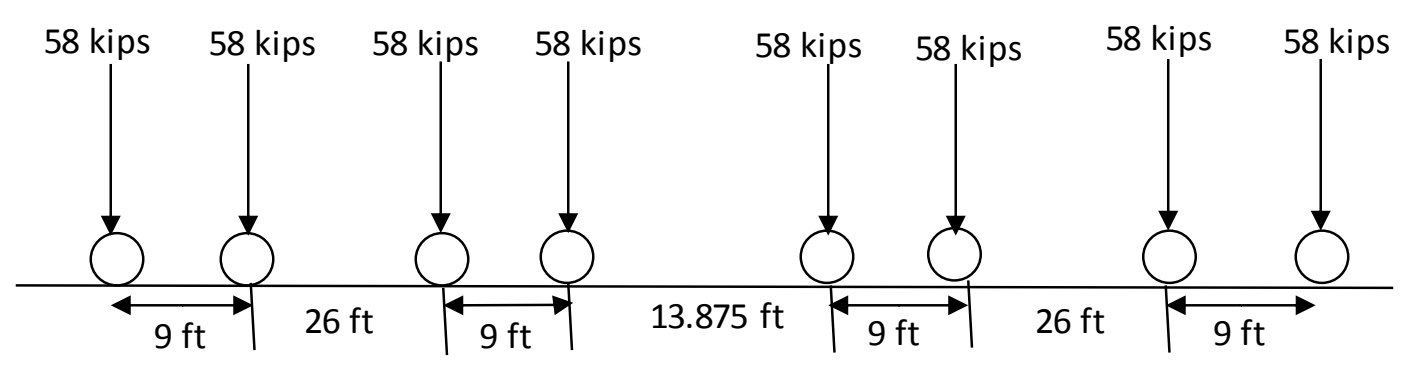

WM-82

58 Kips Axle weight

Figure 43 Axle spacing and Axle Weights of WM 82 (BL-2) Locomotive

\subsubsection{Field Testing Procedure}

Field testing was performed over two days. The locomotive (WM82 BL2 series) and the Hi-Rail Dump Truck with a gross weight of 66.480 Kips were used for testing Bridge 1.4 on day 1. On day 2, a Hi-Rail Dump Truck with a gross weight of 69.860 Kips was used for testing Bridge 5.8. A truss bridge at the milepost 3.0 was unable to carry the locomotive, thus it could not be used on Bridge 5.8. Both vehicles moved slowly over Bridges 1.4 and 5.8, in order to (1) reduce impact effects and (2) to get maximum strain value. A Vishay 7000 data acquisition system was connected to each of the sensors on each bridge. As the data was collected by the strain gages, the vehicle proceeded forward. The vehicle was moved three times (forward, backward and forward) over each bridge. The dump truck was used first during testing, to check if the bridge is in good condition to withstand locomotive loading.

For Bridge 5.8, the load effect was either from the rear axles or the front axle individually as the bridge span was less than the axle spacing. The two rear axles along with the hi-rail rear axle were touching the track and were detected by the photo electric sensors placed on the track as shown in Figure 44. It was found that the peak strain value occurred between the rear axles and 
the Hi Rail rear axle. The center of gravity of the three rear axles was obtained from the graph shown in Figure 44 and located 22. $343 \mathrm{ft}$. from the front hi-rail axle (the front steering axle did not touch).

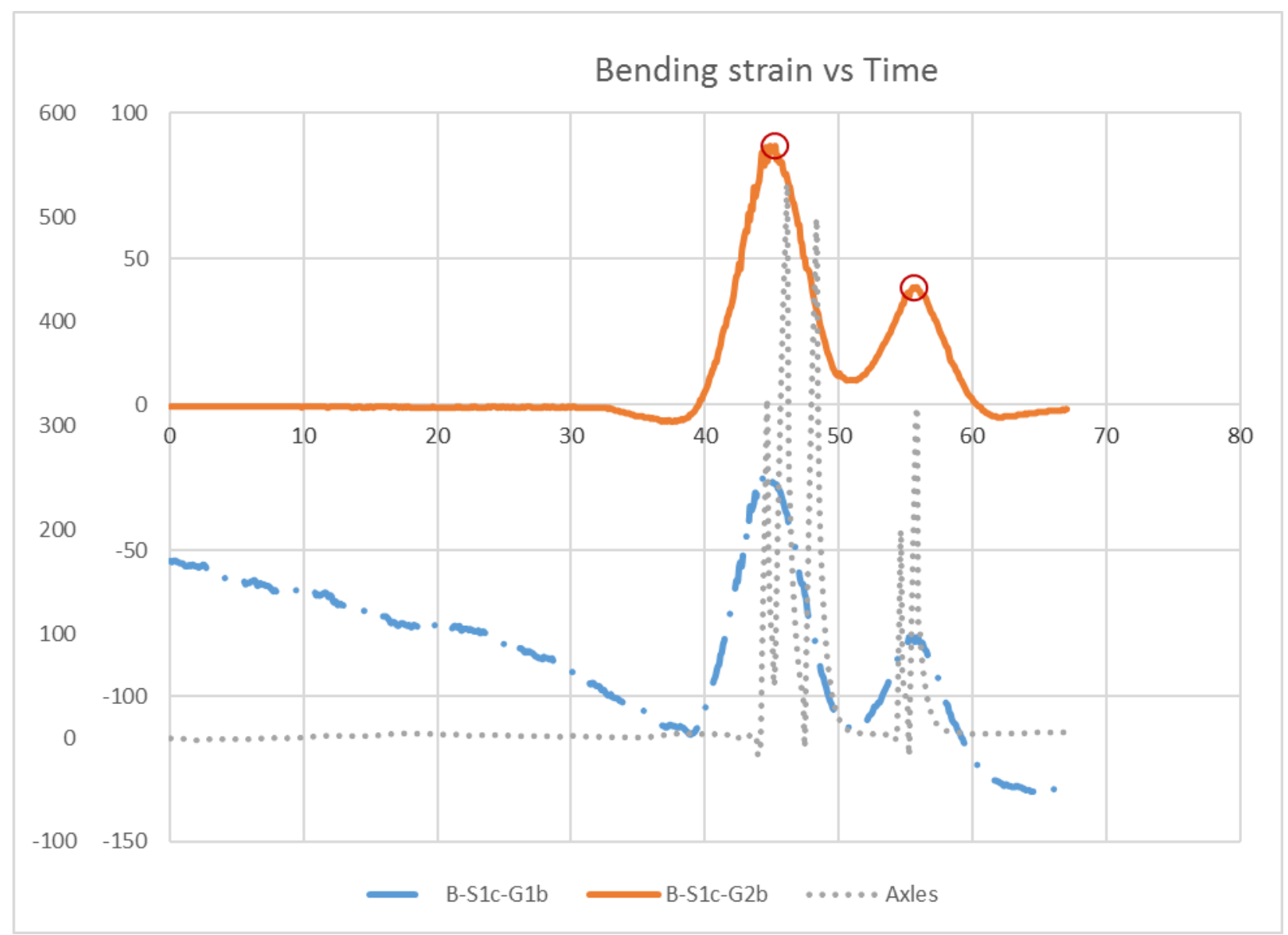

Figure 44- Plot of Bending Strain vs Time of Girder 1 of Bridge 5.8, The Peak Stain is Located Between the Rear Hi-rail Axle and Rear Axle.

The dump truck weight was measured as 66,480 $\mathrm{lbs}$ and 64, $860 \mathrm{lbs}$ for day 1 and day 2 respectively. From the chart above, ratio of strains under rear axle to front axle is 87.9:39.4. Length of the bridge is 17.875 feet, while axle spacing is 22.343 , hence bridge girder can 
experience load from one axle at a time only. Therefore, the ratio of axle loads is same as strains measured, 87.9:39.4.

\section{Calculation:}

Ratio of rear axle strain to front axle strain $=87.9: 39.4$

Ratio of rear axle weight to front axle weight $=87.9: 39.4$

Rear axle weight $=87.9 /(87.9+39.4) \times 100=69.1 \%$

Front axle weight $=39.4 /(87.9+39.4) \times 100=30.9 \%$.

\subsection{Field Testing Results}

An overall weighted average was calculated based on the average of data from all the gages with the vehicle moving in reverse taken twice in the average, as it only moved reverse once. These results obtained from the weighted average approach are then compared to the theoretical results.

Using the bending moment or shear and geometrical properties, the stress values were computed and are shown in appendices A, B, and C. The moments and shears were calculated using RISA structural analysis software in the same manner as the load rating, as shown in Figure 45. 


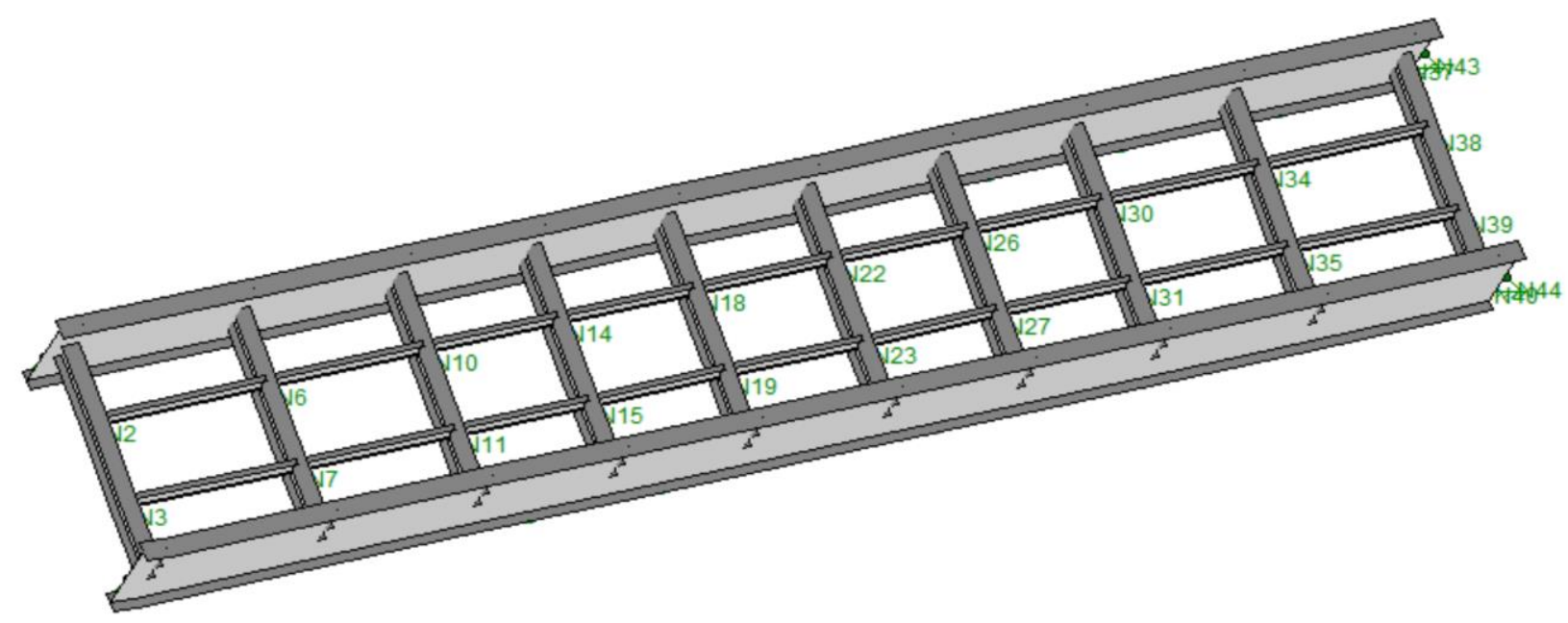

Figure 45- RISA 3D Model of Bridge No. 1.4, Used for Analysis of Maximum Shear and Bending Moments

The theoretical stress value was divided by the modulus of elasticity of steel $\left(E_{\text {STEEL }}=29000\right.$ Ksi) to get the theoretical bending strain value and was compared with the field strains. For shear strains, the obtained shear stress value was divided by the shear modulus $(\mathrm{G}=3 \mathrm{E} / 8)$ to get the theoretical shear strains. The results are explained in Sections 5.2.1 and 5.2.2 respectively.

\subsubsection{Bridge 1.4 and 5.8 Bending and Shear Strains (Truck)}

The gage on top of girder 1 in span 2 and the shear gage on plate girder 2, north east end (36" away from support) failed during field testing. Data was acquired from the remaining 11 gages while the dump truck moved over the bridge and compared with the theoretical strains in Table 11. 
Table 11- Strain Gage Readings of The Field Test Conducted With The Hi rail Dump Truck on Bridges 1.4 and 5.8.

\begin{tabular}{|c|c|c|c|c|c|c|}
\hline Bridge Number & Elements & Type & Span location & Theoretical Strains & Average Field Strains & Percentage Difference \\
\hline \multirow[t]{12}{*}{1.4} & Plate Girder 1 & Bending & Span 1 Center, top & 41.92 & 39.27 & 7 \\
\hline & & Bending & Span 1 Center, bottom & 41.92 & 37.40 & 12 \\
\hline & & & & & & \\
\hline & Plate Girder 2 & Shear & Span 1, Northeast End & 47.83 & 44.94 & 6 \\
\hline & & Bending & Span 1, Center, top & 41.92 & 36.60 & 15 \\
\hline & & Bending & Span 1 Center, bottom & 41.92 & 37.54 & 12 \\
\hline & & Bending & Span 2, Center, top & 41.23 & 39.44 & 5 \\
\hline & & & & & & \\
\hline & Floor Beam & Shear & Span 1, North End & 123.80 & 65.77 & 88 \\
\hline & & Bending & Span 1 Center, bottom & 77.48 & 71.60 & 8 \\
\hline & & & & & & \\
\hline & Stringer & Bending & Span 1 Center, bottom & 77 & 47.54 & 63 \\
\hline \multirow{8}{*}{5.8} & & & & & & \\
\hline & Girder 1 & Shear & $\begin{array}{l}\text { Span } 1 \text { Support, } \\
\text { Northeast. }\end{array}$ & 186.93 & 114.20 & 64 \\
\hline & & Shear & $\begin{array}{c}\text { Span 1, Northeast, } 30 " \\
\text { away from support }\end{array}$ & 160.29 & 107.94 & 49 \\
\hline & & Bending & Span 1 Center, bottom & 141.51 & 95.80 & 48 \\
\hline & & & & & & \\
\hline & Girder 2 & Shear & $\begin{array}{c}\text { Span 1 Support, } \\
\text { Northwest }\end{array}$ & 186.93 & 115.00 & 63 \\
\hline & & Shear & $\begin{array}{c}\text { Span 1 Support, } \\
\text { Northwest }\end{array}$ & 160.29 & 113.30 & 41 \\
\hline & & Bending & Span 1 Center, bottom & 141.51 & 90.10 & 57 \\
\hline
\end{tabular}

As per the strain values, the girder 1 and 2 of span 1 had theoretical values $7 \%$ to $15 \%$ higher than the field strains and girder 2 of span 2 had theoretical strain $5 \%$ higher than the field strain. Since, the theoretical and field strains are similar, it validates the assumptions made in RISA modelling. For the floor beam and stringer, the theoretical bending strains are $8 \%$ and $63 \%$ higher than the field strains respectively. This might be due to inexact end conditions used in the 3D model compared in the field. The 3D model in RISA did not have the bracings which connected the top of floor beam and the web of the plate girders. In terms of the stringers, the gages were installed near the end of the girder, which is an area of uneven stress concentrations which are not reflected in the RISA model. This explains why the field and theoretical strain value were varying. 
In the case of Bridge 5.8, the 40 plus percentage difference between the field and theoretical bending and shear strains is attributed to the track structure contributes to the resistance of bending moment in an open deck type bridge and was not included in modelling of the bridge.

\subsubsection{Bridge 1.4 - Bending and Shear Strains (Locomotive)}

In the case of locomotive, Bridge 1.4 was the only steel bridge that was field-tested. The loads exerted on Bridge 1.4 by the Western Maryland 82 locomotive obtained the average field strains and the theoretical strains as shown in Table 12.

\section{Table 12- Comparison of Strain Gage Readings of the Field Test Strains (WM 82 Locomotive on Bridge 1.4) with Theoretical Strains.}

\begin{tabular}{|c|c|c|c|c|c|}
\hline Elements & Type & Location & Average Field strains & Theoritical Strains & (\%)percentage difference \\
\hline Plate Girder 1 & Bending & Span 1 Center, top & 105.40 & 111.11 & 5 \\
\hline & Bending & Span 1 Center, bottom & 98.00 & 111.11 & 13 \\
\hline & & & & & 135.21 \\
\hline Plate Girder 2 & Shear & $\begin{array}{c}\text { Span 1 Support, } \\
\text { Northeast }\end{array}$ & 128.30 & 111.11 & 5 \\
\hline & Bending & Span 1 Center, top & 94.30 & 111.11 & 18 \\
\hline & Bending & Span 1 Center, bottom & 102.60 & 108.74 & 8 \\
\hline & Bending & Span 2 Center, top & 97.10 & & 12 \\
\hline & & & & 203.39 & 50 \\
\hline Floor Beam & Shear & Span 1 Support, North & 135.25 & 152.50 & 10 \\
\hline & Bending & Span 1 center, bottom & 138.30 & & \\
\hline
\end{tabular}

On comparison with the field micro strains (bending and shear), plate girders 1 and 2 (top and bottom) of span 1 and the girder 2 (top) of span 2, had theoretical micro strain values (bending and shear) that are nearly equal. This confirms that the assumptions made while modeling in RISA are correct. The floor beam theoretical shear strain was $50 \%$ higher than the average field strain value. As mentioned previously in section 5.2.1, the theoretical strains are affected as the RISA model did not account for the inclined bracings. This might be the reason for the difference between theoretical and field shear strains. The ratios of the train to truck (micro strains) are displayed below in Table 13and Table 14 . 
Table 13- Ratios of Average Field Micro Strain Values Obtained From Train and Truck.

\begin{tabular}{|c|c|c|c|}
\hline Strain Gage Location & Avg. Field Microstrains (Train) & Avg. Field Microstrains (Truck) & Average Field Microstrain Ratio (Train to Truck) \\
\hline B-S1c-G1t & 105 & 39 & 2.68 \\
\hline B-S1c-G1b & 98 & 37 & 2.62 \\
\hline & & & 2.85 \\
\hline S-S1n-G2e 36 inches away & 128 & 45 & 2.58 \\
\hline B-S1c-G2t & 94 & 37 & 2.73 \\
\hline B-S1c-G2b & 103 & 38 & 2.46 \\
\hline B-S2c-G2t & 97 & 39 & 2.06 \\
\hline & & & 1.93 \\
\hline S-S1n-Fs & 135 & 66 & \\
\hline B-S1c-Fc & 138 & 71.60 & 1.57 \\
\hline B-S1c-S1c & 75 & & \\
\hline
\end{tabular}

Table 14- Ratios of Theoretical Micro Strain Values Obtained From Train and Truck.

\begin{tabular}{|c|c|c|c|}
\hline Strain Gage Location & Theoretical Strains(Train) & Theoretical Strains (Truck) & Theoretical Strain Ratio (Train to Truck) \\
\hline B-S1c-G1t & 113 & 42 & 2.70 \\
\hline B-S1c-G1b & 113 & 42 & 2.70 \\
\hline & & & 2.89 \\
\hline S-S1n-G2e 36 inches away & 138 & 48 & 2.70 \\
\hline B-S1c-G2t & 113 & 42 & 2.70 \\
\hline B-S1c-G2b & 113 & 42 & 2.68 \\
\hline B-S2c-G2t & 111 & 41 & 1.64 \\
\hline & & & 1.97 \\
\hline S-S1n-Fs & 203 & 124 & 1.08 \\
\hline B-S1c-Fc & 153 & 77.48 & \\
\hline B-S1c-S1c & & & \\
\hline
\end{tabular}

The theoretical strain ratio of the floor beam shear is 1.64 and the average field strain ratio is 2.06. As explained previously, due to restrictions in the software analysis, some of the elements along with the end conditions could not be properly replicated while modelling the bridge, including the assumption that locomotive load has been distributed evenly to all the axles. These might be the reasons which affect the theoretical strain values and the ratios.

\subsubsection{Compression (Explained by Strain Response)}

Plate girder 2 of Bridge 1.4 had two strain gages fixed on the vertical legs of the interior and exterior bottom angles. The location of the gages was exactly above the abutment 1 on the north, adjacent to the northwest side of the floor beam 1 as shown in Figure 46. 


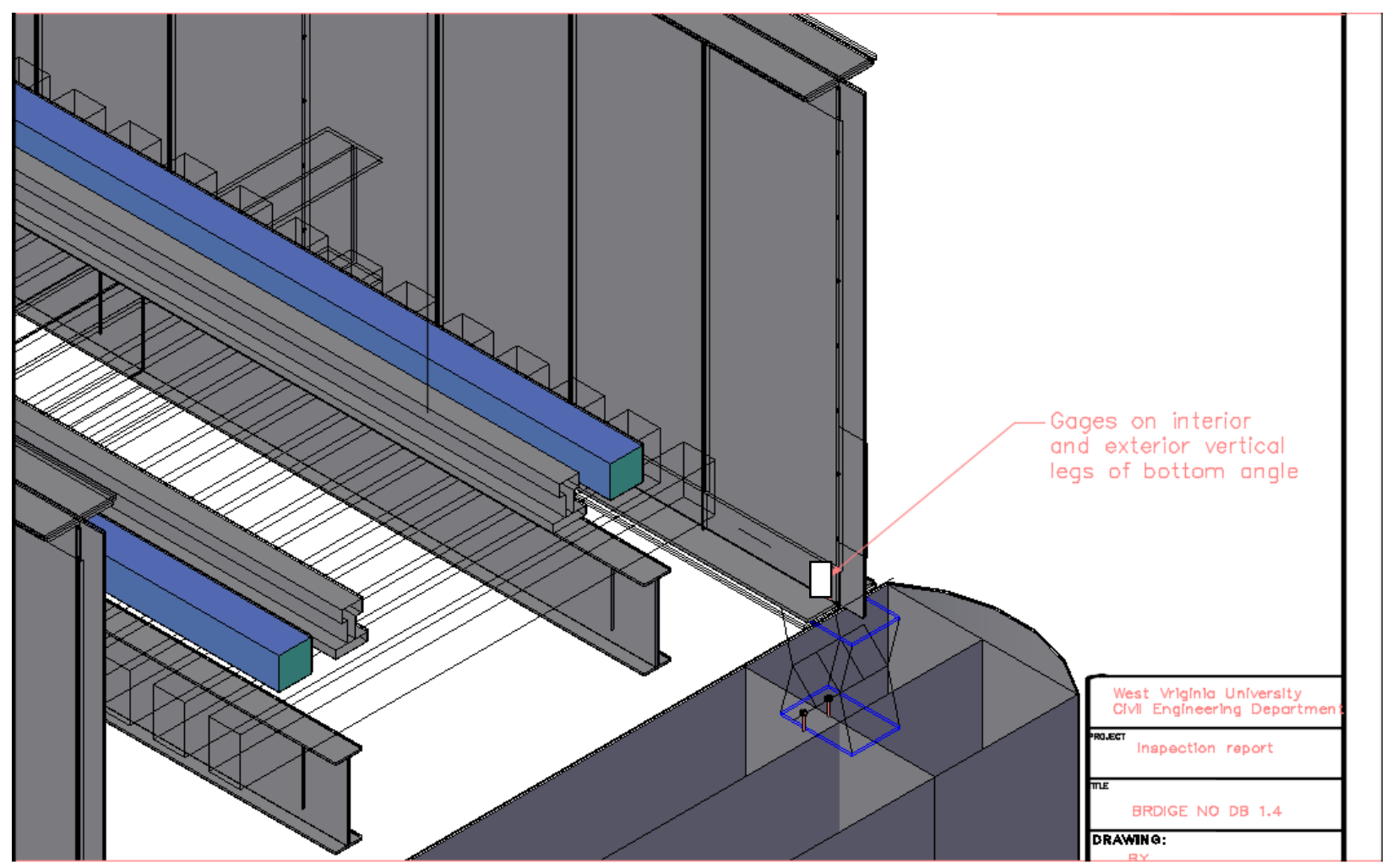

Figure 46- Location of Gages Fixed on Interior and Exterior Vertical Legs of Bottom Angles.

The purpose of the gages fixed to the bottom angles was to know if the corrosion activity on the bottom interior flange angle affected the ability to resist the compression. The results obtained from field testing can be seen in Table 15.

Table 15- Measured Strains During Field Testing, Strain Gages Fixed to The Interior and Exterior Vertical Legs of Bottom Angles at Northwest End of girder 2.

\begin{tabular}{|c|c|c|}
\hline VEHICLE & STRAIN-INSIDE ANGLE & STRAIN-OUTSIDE ANGLE \\
\hline LOCOMOTIVE & 170.1 & 18.8 \\
\hline TRUCK & 65.3 & 2.7 \\
\hline
\end{tabular}


The strain values from the strain gages fixed to the bottom inner and outer angles were obtained at the same time. The inside angle for both the locomotive and truck case has responded with strain values of $86 \%$ and $96 \%$ more than the outer angle, respectively. Hence, the observed strain values indicate that (1) there is an out of plane bending on the plate girder and (2) the section loss due to corrosion activity on interior angles has not affected the bearing strength. This also infers that the assumption of end conditions of floor beams-girders is accurate while modelling the bridge in RISA.

\subsubsection{Deflection}

AREMA manual 2014, Chapter 15-Section 1.2.5.b limits deflections to L/640. The deflection values obtained from filed testing and from RISA are tabulated and compared with the AREMA limits in Table 16. The values obtained from RISA are somewhat higher than the values obtained from field testing. However, both the field and RISA values are within the AREMA limits.

Table 16- Deflection Measurements of Steel Bridges 1.4

\begin{tabular}{|c|c|c|c|c|c|c|c|c|}
\hline Bridge No & Member & $\begin{array}{c}\text { Length of } \\
\text { the }\end{array}$ & Vehicle & Theory & $\begin{array}{l}\text { Avg. Field } \\
\text { Deflection }\end{array}$ & $\begin{array}{c}\text { Prorated to E-80 } \\
\text { Theory } \\
\end{array}$ & $\begin{array}{c}\text { Prorated to E-80 } \\
\text { Field }\end{array}$ & AREMA LIMIT \\
\hline \multirow[t]{3}{*}{1.4} & Girder 1 & 97.05 & \multirow{3}{*}{ Train } & 0.369 & 0.2975 & 1.58 & 1.273 & 1.820 \\
\hline & Girder 2 & 97.05 & & 0.369 & 0.31 & 1.580 & 1.327 & 1.820 \\
\hline & Floor beam & 17.5 & & 0.06 & 0.045 & 0.660 & 0.499 & $\mathrm{~N} / \mathrm{A}$ \\
\hline \multirow[t]{3}{*}{1.4} & Girder 1 & 97.05 & \multirow{3}{*}{ Truck } & 0.123 & 0.101 & 1.365 & 1.121 & 1.820 \\
\hline & Girder 2 & 97.05 & & 0.123 & 0.104 & 1.365 & 1.154 & 1.820 \\
\hline & Floor beam & 17.5 & & 0.036 & 0.027 & 0.290 & 0.2178 & N/A \\
\hline
\end{tabular}




\subsection{Summary of Field Testing}

In this chapter field testing details are provided including test procedure, data recording, and analysis. Data was acquired from 11 gages including shear and bending and 3 LVDTs on Bridge 1.4 and 6 gages on Bridge 5.8 .

For both the truck and locomotive, the girders of span 1 of Bridge 1.4 had theoretical bending strains were $7 \%$ to $15 \%$ higher than the field strains and girder 2 of span 2 had theoretical strain $5 \%$ and $14 \%$ higher than the field strains, respectively. The difference in strain values was similar to those predicted by RISA modeling The floor beam shear and bending theoretical strains are $88 \%, 8 \%$ (for truck) and 50\%, 10\% (locomotive) higher than field strains. For stringers, the theoretical bending strains are 63\% (truck) and 12\% (locomotive) higher than field strains. The difference in the results are attributed to braces connected from the web of the plate girder to the top of floor beam which were not modeled in RISA

In the case of Bridge 5.8, the theoretical strains were on an average $52.5 \%$ and $54.25 \%$ higher than the field strains for bending and shear respectively. This is attributed to the track structure not being modeled in RISA.

LVDT's were used to obtain the deflections of plate girders of Bridge 1.4. The deflection values obtained from RISA are higher than the values obtained from field testing, but both values are within the AREMA limits. Hence, the steel bridges are stiffer than the model predicts and are well within AREMA limits.

The gages fixed to the vertical legs of the bottom flange of the plate girder 2 show that the member was not affected by the section loss. The strain value observed for inside angle was $96 \%$ 
and $86 \%$ higher than the strain values observed for the outside angle and indicates that there is an out of plane bending on the plate girder. 


\section{Chapter 6 \\ CONCLUSIONS AND RECOMMENDATIONS}

The following conclusions and recommendations are based on the inspection reports, field testing, RISA analysis and load rating analysis results for Bridges 1.4 and 5.8 on the WVCR Dailey Branch.

- The field testing was performed for Bridges 1.4 and 5.8 measuring deflections, strains including flexural compression, flexural tension and shear strains for girders, floor beams and stringers. Field testing results from the WM 82 locomotive and hi-rail dump truck were compared with analytical results.

- Field testing results obtained for main girders of Bridge 1.4 were in the range of $5 \%$ to $12 \%$ lower than the analytical results in the case of hi-rail dump truck and $7 \%$ to $10 \%$ lower than the analytical results in the case of locomotive.

- Bridge 1.4 floor beam shear strains measured in the field are found to be $50 \%$ and $88 \%$ lower than the analytical results in the case train and truck respectively. This is likely due to the bracing between the floor beam and the girder that was not included in the model.

- For the stringers on Bridge 1.4, the field testing results for flexural strain were $63 \%$ lower than the analytical strains for the hi-rail dump truck load, and $12 \%$ lower than the analytical result for locomotive. This is likely due to stress concentrations in the gage location not being accounted for in the model as the gage was installed at the end of the stringer. 
- For Bridge 5.8, the field test results for flexural strains were $48 \%$ to $57 \%$ and shear strains $41 \%$ to $63 \%$ lower than analytical strain. This discrepancy may be due to the contribution from the track structure not being accounted for in the analytical model.

- LVDT's were used to obtain the deflections of plate girders of Bridge 1.4. The deflection values obtained from RISA are higher than the values obtained from field testing, but both the values are within the AREMA limits. Hence, Bridge 1.4 is stiffer than the RISA modeling suggests and well below the AREMA limits.

- Gages fixed to the vertical legs of the bottom flange of the plate girder 2 on Bridge 1.4 show the girder has not been affected by the section loss. The strain value observed for inside angle was $96 \%$ and $86 \%$ higher than the strain values observed for the outside angle and indicates that there is an out of plane bending on the plate girder.

- Field inspection included embankment and bridge approach condition assessment. There was no evidence of any settlements and disruption of embankments, however gaps were observed between track and subgrade indicating draining out of ballast due to loosened surface material. Regular inspection for track and embankment stability are recommended at both the bridge sites. Further, building timber walls to prevent sliding of ballast is recommended to stabilize embankment and to prevent major maintenance issues.

- No structural strengthening is necessary attributing to sufficient rating of the bridge members and field inspections. 
- Load ratings were calculated based on WVU-CFC inspection data. Equipment ratings were calculated for 286k railcar, GP 38, GP 9, and WM 82 locomotive. Comparison of bridge member rating with corresponding equipment, concluded that both Bridges 1.4 and 5.8 have sufficient capacity to carry the equipment analyzed herein at normal rating at $10 \mathrm{mph}$.

\section{Recommendations}

- The slopes of the embankments of the bridges have ballast rolling down. Building timber walls, usage of gabions might maintain the ballast level.

- Both the steel bridges need cleaning and painting of members to address corrosion.

- An inspection of the bridges at a regular 3-year interval is recommended, as some of the findings in the inspection report are classified as C3.

- If periodic inspection in future reveals any considerable section loss, load rating considering section loss shall again be performed. The results can be validated with field testing. 


\section{REFERENCES}

- AAR Bridge Safety. (2016). AAR Bridge Safety. Retrieved June 24, 2016, from AAR: https://www.aar.org/Pages/Bridges.aspx.

- Aflatooni, M. (2015). Synthetic Rating System For Railway Bridge. Queensland: Queensland university. Retrieved from http://eprints.qut.edu.au/81784/1/Mehran_Aflatooni_Thesis.pdf.

- Anand J. Puppala, S. S. (2009). Recommendations for design construction, and maintenance of bridge approach slabs: synthesis report. Austin: University of Texas at Arlington.

- AREMA (2014). Manual for Railway Engineering, The American Railway Engineering and Maintenance-of-Way Association. Lanham, Maryland.

- ASCE. (2009). Infrastructure Fact Sheet- Fact About Transportation Bridges (2009 Report Card). $\quad$ Retrieved from http://www.infrastructurereportcard.org/2009/sites/default/files/RC2009_bridges.pdf

- Bacinskasa, D., Kamaitisa, Z., Jatulisa, D., Kilikevicius, A. (2013). Field Testing of Old Narrow-Guage Railway Steel Truss Bridge. 11th international conference Modern Building Materials, Structures and Techniques, MBMST 2013, Procedia Engineering Vol 57 , pages $136-143$.

- Beczkowski, H. (2002). Track Structure Renewal on Polish State Railways. Rail Engineering International Edition 2002. De Rooi .

- Bellin, J. (1993, august 13). Bridge Approaches. Oregon Department Of Transportaion.

- Brickenhoff, P. (2004). Guidelines for Load Rating - Trasit Bridges. Massachusetts Bay Transportation Authority. 
- Caltrans Geotechnical Manual. (2014). Caltrans. Sacramento, California, USA.

- Car Library (2003). Car library, CN Mechanical Department.

- Centerflow (2016). 3528 Centerflow ${ }^{\circledR}$ Cover Hopper Car Specifications, American Railcar Industries. http://www.americanrailcar.com/Manufacturing/CenterflowCars . (Last accessed on 06/24/2016)

- Diesel unit data book (2003). Diesel unit data book from years 1966 -2003, CN Mechanical Department.

- E. Ghafoori, M. M. (2015). Design Criterion For Fatigue Strengthening of Riveted beams in a 120- Year Old Railway Metallic Bridge Using Pre-Stressed CFRP Plates. Composites: Part B, 1-13.

- Government of Australia, (2003). Guide to the Design of the Bridge Approach Embankments Subject to Inundation. 1-9. Australia.

- GATX (2016). GP 38 Locomotives, GATX Corporation. http://www.gatx.com/wps/wcm/connect/GATX/GATX_SITE/Home/Rail+North+Americ a/Products/Equipment+Types/Locomotives/GP38/ (Last accessed on 06/24/2016)

- GATX GP 38-2 (2016). GP 38 Locomotives, GATX Corporation. http://www.gatx.com/wps/wcm/connect/GATX/GATX_SITE/Home/Rail+North+Americ a/Products/Equipment+Types/Locomotives/GP38-2/ (Last accessed on 06/24/2016)

- G.Barker, M. (1999). Field Testing and Load Rating Procedures for Steel Girder Bridges. Jefferson: Missouri Department of Transportation.

- Gavin, K. (2014). Smart Maintenance, Analysis and Remediation of Transport StructureSMARTRAIL - Final Report. Dublin: The SMARTRAIL consortium. 
- Hakon Heyerdahl, O. A. (2013). Rainfall- Induced Collapse of Old Railway Embankments in Norway. 18th International Conference on Soil mechanics and Geotechnical Engineering (18th ICSMGE): Volume 2. Paris.

- H.W.lochner, (2012). Railroad Bridge Inspection Manual. Connecticut Department of Transportation and H.W. Lochner inc. Retrieved from http://www.ct.gov/dot/lib/dot/railroad_bridge_inspection_manual.pdf

- Hongbo Liu, R. A.-M.-L. (2009). Experimental Study of Fatigue Crack Growth Behaviour in Adhesively Reinforces Steel Structures. Composite Structures, 12-20.

- J.F. Unsworth, P. (2002). Evaluation of the load capacity of a rehabilitated steel arch railway bridge. AREMA conference proceedings 2002. Washinton D.C.

- Joakim Wallin, J. L. (2011). Strengthening of a Steel Railway Bridge and Its Impacr on the Dynamic Response to Passing Trains. Enginering Structures, 635-646.

- John Ermopulous, C. C. (2005). Validated Analysis and Strengthening of a 19th Century railway Bridge. Engineering Structures,28., 783-792.

- John F. Unsworth, P. (2003). Heavy Axle Load (HAL) Effects on Fatigue Life of Steel Bridges. Alberta: Effect on Fatigue Life of Steel Bridges. Transportation Research Record: Journal of The Transportation Research Board 1825, 38-47.

- Kenneth R. Kirschling, P. (2012). Railroad Bridge Rating Report. Winooski: Rail Star Engineering LLC.

- Kevin Bollinger (2015). Railroad bridge dynamics and ratings. Final Report for Rail Safety IDEA Project 24, Transportation Research Board.

- McVarish, D. C. (2016). American Industrial Archeology. New york: Routledge. 
- Nauman Khurram, E. S. (2014). Analytical Demonstration to Assess Residual Bearing Capacities of Steel Girder ends with Bearing Stiffeners Damaged by Corrosion. Structure and Infrastructure Engineering - Maintenance, Management, Life-Cycle Design and Peformance, Volume 10, Issue 1, 69-79.

- Operations, J. C. (2005). Preliminary Performance Review - State Rail Authority. Charleston: WV Legislative Auditor.

- Otter D., (2009). Vertical loads from North American rolling stock for bridge design and rating, AREMA Proceedings of The 2009 Annual Conference \& Exposition, Chicago, IL.

- Philbrick, T. G. (1995). Fatigue Assessment of Through Plate Girder Railway Bridges. Journal of Structural Engineering, ASCE, Vol. 121, No.11., 1613-1619.

- Piya chotickai, T. K. (2010). Field Testing and Performace Evaluation of a ThroughPlate Girder Railway Bridge. Journal of the Transportation Research Board.

- Potter, B. C. Fracture-Critical- Bridges- Simple Supports. wordpress cooporation. Retrieved from: https://simplesupports.wordpress.com/2013/05/28/fracture-criticalbridges/.

- Hasan QA, et al. The state of the art of steel and steel-composite plate girder bridges. Part I: Straight plate girders. Thin-Walled Structures (2015), http://dx.doi.org/10.1016/i.tws.2015.01.014.

- Robert J. Dexter, R. J. (2005). Review of Steel bridges with Fracture Critical Elements. Transportation Research Record: Journal of the Transportation Research Board, No. 1928, Transportation Research Board of the National Academics., 75-82.

- R.Kliger, M. Al.-Emrani. (2009). Fatigue Prone Details in Steel Bridges. NSCC. Retrieved from http://www.nordicsteel2009.se/pdf/147.pdf. 
- Sorgenfrei, D. M. (2000). Railroad Bridges-Bridge engineering Handbook. Boca Raton: CRC press LLC.

- The Diesel Shop (2016). Retrieved from http://www.thedieselshop.us/Data\%20EMD\%20GP38.HTML

- Unsworth., J. (2010). Design of modern steel railway bridges. Boca Raton: CRC Press.

- US-DOT. (1988). Checklis And Guidelines For Review of Geotechnical Reports and Preliminary Plans And Specifications. FHWA.

- Vajdic Marko, L. D. (2014). Application of Different Mehods for Rehabilitation of Existing Transition Zones on the Old Railway Lines. Transportation Research Arena (TRA) 5th Conference: Transport Solutions from Research to Depolyment. Paris.

- Weiwei Lin, T. Y. (2013). Performance of Strengthened hybrid strcuctures renovated from old railway bridges. Journal of Construction Research, 130-139.

- WIDOT (2006). Impact of railcar weight change on bridges of the state of Wisconsin owned railroad system, Wisconsin Department of Transportation, prepared by Westbrook Associated Engineering, Inc. and E80 Plus Constructors, LLC.

- William B. Conway, (2001). Practical Application of the Rating Rules. New Orleans: Modjeski and Masters, Inc. AREMA Proceedings of The 2001 Annual Conference, Chicago, IL

- WSDOT Geotechnical Manual. (2013). Olympia, Washington, USA.

- WVDOT (2016). WV Central Road http://www.transportation.wv.gov/rail/WVCR/Pages/default.aspx (Last accessed on June 26, 2016). 
- WV Statewide Rail Plan (2013). Inventory and profile of WV Class II and III railroads, WV statewide rail plan West Virginia Department of Transportation, State Sail Authority Retrieved from http://www.westvirginiarailplan.com/Libraries/West_Virginia_Final_Rail_Plan/WVA_R ail_Plan_FINAL.sflb.ashx (Last accessed on June 26, 2016). 


\section{APPENDIX-A}




\section{LOAD RATING ANALYSIS - THROUGH GIRDER}

Bridge-1.4

\begin{tabular}{|c|c|c|c|}
\hline Steel density: & $\Upsilon_{s}=$ & $490 \mathrm{lb} / \mathrm{ft}^{3}$ & Through Girder \\
\hline Span Length: & $L=$ & $97.042 \mathrm{ft}$ & \\
\hline Number of Girders: & $\mathrm{n}=$ & 2 & \\
\hline Degree of Curve: & $D=$ & 0 degree & \\
\hline Moment of Inertia: & $\mathrm{I}_{\mathrm{xx}}=$ & 396294 in $^{4}$ & \\
\hline Section Modulus: & $\mathrm{S}_{\mathrm{x}}=$ & $6728 \mathrm{in}^{3}$ & \\
\hline Poissons Ratio: & $\mu=$ & 0.3 & \\
\hline C/S Area , Girder: & $A_{x}=$ & $155.9 \mathrm{in}^{2}$ & \\
\hline Radius of Gyration: & $r_{Y}=$ & 3.79 in & \\
\hline $\begin{array}{c}\text { Unbraced Length: } \\
\text { Yield Stress }\end{array}$ & & $\begin{array}{l}11.25 \mathrm{ft} \\
30000 \mathrm{psi}\end{array}$ & 3.3 \\
\hline Modulus of Elasticity & $E=$ & $9000000 \mathrm{psi}$ & $\begin{array}{l}\text { (In the absence of } \\
\text { material yield strength } \\
\text { from tests, the section in } \\
\text { the AREMA manual } \\
\text { suggests to take } \\
F_{y}=30 \mathrm{Ksi} \\
\text { for old steel.) }\end{array}$ \\
\hline
\end{tabular}

Allowable Stresses for Rating:

AREMA 7.3.4.3 and Table 15-1-11 and 15-7-1

Bending Moment:

\begin{tabular}{|c|c|c|c|c|c|c|}
\hline \multirow[b]{2}{*}{ Tension: } & \multicolumn{3}{|c|}{ Normal } & \multicolumn{3}{|c|}{$\underline{\text { Maximum }}$} \\
\hline & $\mathrm{F}_{\mathrm{bpn}}:-$ & $0.55 * \mathrm{~F}_{\mathrm{Y}}=$ & $16500 \mathrm{psi}$ & $F_{\mathrm{bpm}}:-$ & $0.8 * \mathrm{~F}_{\mathrm{Y}}=$ & 24000 psi \\
\hline & \multicolumn{3}{|c|}{ (Bending stress in tension, normal) } & \multicolumn{3}{|c|}{ (Bending stress in tension, maximum) } \\
\hline
\end{tabular}

\section{Bending Moment:}

Compression:

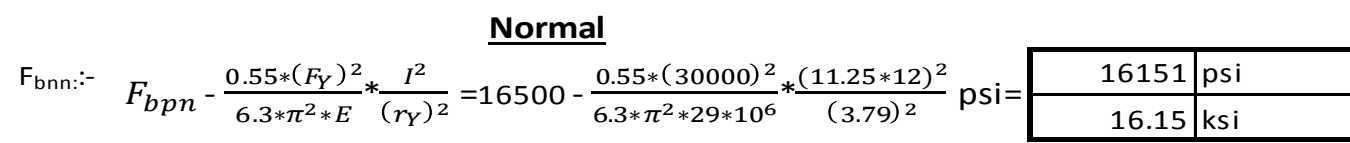

\section{Normal}

\section{Maximum}

$$
\mathrm{F}_{\mathrm{bnm}}:-F_{b p m}-\frac{0.8 * F_{Y}}{1.8 * 10^{9}} * \frac{I^{2}}{\left(r_{Y}\right)^{2}}=24000-\frac{0.8 * 30000}{1.8 * 10^{9}} * \frac{(11.25 * 12)^{2}}{(3.79)^{2}}
$$

psi $=$\begin{tabular}{r|l|}
\hline 24000.0 & psi \\
\hline 24.00 & $\mathrm{ksi}$ \\
\hline
\end{tabular}

Bending Moment:
Table 15-1-11 $\left\{\begin{array}{rl|r|r|l|}\mathrm{F}_{\mathrm{bn}}:^{-} & \min \left(\mathrm{F}_{\mathrm{bpn}}, \mathrm{F}_{\mathrm{bnn}}\right)= \\ \mathrm{F}_{\mathrm{bm}}:^{-} & \min \left(\mathrm{F}_{\mathrm{bpm}}, \mathrm{F}_{\mathrm{bnm}}\right)=\end{array} \quad \begin{array}{rl|l|l|}16151 & \mathrm{psi} & 16.15 & \mathrm{ksi} \\ \hline 23999.98 & \mathrm{psi} & \longrightarrow 24.00 & \mathrm{ksi} \\ \hline\end{array}\right.$

Shear:

$$
\begin{aligned}
& F_{v n}:-0.35 * F_{Y}= \\
& \begin{array}{|r|l|}
\hline 10500 & \text { psi } \\
\hline 10.5 & \mathrm{ksi} \\
\hline
\end{array} \\
& F_{\mathrm{vm}}:-0.6 * F_{Y}= \\
& 18000 \mathrm{psi} \\
& 18 \mathrm{ksi}
\end{aligned}
$$

$\mathbf{F}_{\text {bpn:- }}$ Bending stress in tension, normal

$\mathbf{F}_{\text {bpm }}$ :- Bending stress in tension, maximum

$\mathbf{F}_{\mathrm{Vn}_{\mathbf{n}}}$ :- Shearstress, normal 
*All measurements checked by WVU-CFC during an inspection in May-2014

WEB:

$\begin{aligned} \text { Web }_{\text {depth }}= & \mathrm{W}_{\mathrm{d}}= & 114.25 & \text { inches } \\ \text { Web }_{\text {thickness }}= & \mathrm{W}_{\mathrm{t}}= & 0.44 & \text { inches }\end{aligned}$

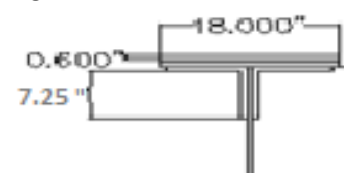

ANGLE:

$\begin{array}{rlll}\text { Leg }_{\text {vertical }}= & \mathrm{V}_{\text {leg }}= & 7.94 & \text { inches } \\ \text { Leg }_{\text {horizontal }}= & \mathrm{H}_{\text {leg }}= & 7.25 & \text { inches } \\ \text { Leg }_{\text {thickness }}= & \mathrm{T}_{\text {leg }}= & 0.69 & \text { inches }\end{array}$

COVER PLATE (CP): 6 in number.

Width $_{\mathrm{CP}}=\quad 18$ inches

Thickness $_{\mathrm{CP}}=\quad 0.6$ inches

no: of cover plates : $\quad \mathrm{n}_{\mathrm{CP}}=6.0$

Area of cross section:

$$
\begin{aligned}
& A_{x}=(114.25 * 0.4375)+[2 *(7.94 * 0.69)]+[2 *(7.25 * 0.69)]+(6 * 18 * 0.6) \\
& A_{x}=155.88 \text { in }^{2}
\end{aligned}
$$

Moment of inertia:

$$
\begin{aligned}
\mathrm{I}_{\mathrm{xx}}= & 2\left[\frac{18 * 0.6^{3}}{12} *(18 * 0.6) *\left(\left(\frac{114.25}{2}\right)+\left(\frac{0.6}{2}\right)\right)^{2}\right]+\left[2 * \frac{18 * 0.6^{3}}{12} *(18 * 0.6) *\right. \\
& {\left.\left[\left(\frac{114.25}{2}\right)+0.6+\left(\frac{0.6}{2}\right)\right]^{2}\right]+\left[2 * \frac { 1 8 * 0 . 6 ^ { 3 } } { 1 2 } * ( 1 8 * 0 . 6 ) * \left[\left(\frac{114.25}{2}\right)+0.6+\right.\right.} \\
& \left.\left.0.6+\left(\frac{0.6}{2}\right)\right]^{2}\right]+\left[\frac{0.4375 * 114.25^{3}}{12}\right]+\left\lfloor 4 * \frac{7.9375 * 0.6875^{3}}{12}(7.9375 * 0.6875) *\right. \\
& \left.\left(\left(\frac{114.25}{2}\right)-\left(\frac{0.6875}{2}\right)\right)^{2}\right\rfloor+4\left\lfloor\left(\frac{0.6875 * 7.25^{3}}{12}\right)+(7.25 * 0.6875) *\left(\left(\frac{114.25}{2}\right)-\right.\right. \\
& \left.\left.\left(\frac{7.25}{2}\right)\right)^{2}\right]
\end{aligned}
$$

$$
I_{x x}=\quad 396294 \text { in }^{4}
$$

Section Modulus:

$$
\begin{aligned}
& \mathrm{S}_{\mathrm{X}}=\frac{I_{x x}}{\frac{\left(w_{d}+\left(n_{c p} * \text { Thickness }_{C P}\right)\right)}{2}} \\
& \mathrm{~S}_{\mathrm{X}}=
\end{aligned}
$$

Radius of Gyration :

$$
r_{\mathrm{y}}=\sqrt{\frac{I_{y y}}{A}}=\sqrt{\frac{2237}{155.88}} \quad 3.79 \text { inches }
$$


Moment of Inertia - Strong Axis - (Units- Inches)

Web
\begin{tabular}{|c|c|c|c|c|c|}
\hline Base & Height & Area & Y & I $_{0}$ & $I_{\mathbf{x x}}$ \\
\hline 0.44 & 114.25 & 49.98 & 0 & 54370.76 & 54371 \\
\hline
\end{tabular}

Cover Plate 3

Cover Plate 2

\section{Cover Plate 1}

\begin{tabular}{|c|c|c|c|c|c|}
\hline Base & Height & Area & $Y$ & $\mathrm{I}_{0}$ & $\mathrm{I}_{\mathbf{x x}}$ \\
\hline 18 & 0.6 & 10.69 & 57.42 & 0.31 & 35240 \\
\hline
\end{tabular}

\section{Cover Plate 1}

Cover Plate 2

\begin{tabular}{|c|c|c|c|c|c|}
\hline Base & Height & Area & $Y$ & $\mathrm{I}_{0}$ & $\mathrm{I}_{\mathbf{x x}}$ \\
\hline 18 & 0.6 & 10.69 & 58.02 & 0.31 & 35972 \\
\hline
\end{tabular}

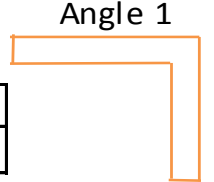

Cover Plate 3

\begin{tabular}{|c|c|c|c|c|c|}
\hline Base & Height & Area & $Y$ & $\mathrm{I}_{\mathbf{0}}$ & $\mathrm{I}_{\mathbf{x x}}$ \\
\hline 18 & 0.6 & 10.69 & 58.61 & 0.31 & 36713 \\
\hline
\end{tabular}

Cover Plate 4

\begin{tabular}{|c|c|c|c|c|c|}
\hline Base & Height & Area & $Y$ & $\mathrm{I}_{\mathbf{o}}$ & $\mathrm{I}_{\mathbf{x x}}$ \\
\hline 18 & 0.6 & 10.69 & -57.42 & 0.31 & 35240 \\
\hline
\end{tabular}

Cover Plate 5

\begin{tabular}{|c|c|c|c|c|c|}
\hline Base & Height & Area & $Y$ & $\mathrm{I}_{\mathbf{0}}$ & $\mathrm{I}_{\mathbf{x x}}$ \\
\hline 18 & 0.6 & 10.69 & -58.02 & 0.31 & 35972 \\
\hline
\end{tabular}

Cover Plate 6

\begin{tabular}{|c|c|c|c|c|c|}
\hline Base & Height & Area & $Y$ & $I_{0}$ & $I_{\mathbf{x x}}$ \\
\hline 18 & 0.6 & 10.69 & -58.61 & 0.31 & 36713 \\
\hline
\end{tabular}

Angle 1

Angle 2

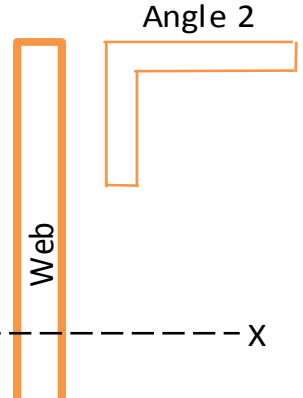

$x-------------x$

\section{Angle 3}

Angle 4

\begin{tabular}{|c|c|c|c|c|c|c|}
\hline Base & Height & Area & $Y$ & $\mathrm{I}_{\mathrm{o}}$ & $\mathrm{I}_{\mathbf{x x}}$ & Component \\
\hline 7.94 & 0.69 & 5.46 & 56.78 & 0.21 & 17594 & Horizontal leg of angle 1 \\
\hline 0.69 & 7.25 & 4.98 & 52.81 & 21.83 & 13924 & Vertical leg of angle 1 \\
\hline 7.94 & 0.69 & 5.46 & 56.78 & 0.21 & 17594 & Horizontal leg of angle 2 \\
\hline 0.69 & 7.25 & 4.98 & 52.81 & 21.83 & 13924 & Vertical leg of angle 2 \\
\hline 7.94 & 0.69 & 5.46 & -56.78 & 0.21 & 17594 & Horizontal leg of angle 3 \\
\hline 0.69 & 7.25 & 4.98 & -52.81 & 21.83 & 13924 & Vertical leg of angle 3 \\
\hline 7.94 & 0.69 & 5.46 & -56.78 & 0.21 & 17594 & Horizontal leg of angle 4 \\
\hline 0.69 & 7.25 & 4.98 & -52.81 & 21.83 & 13924 & Vertical leg of angle 4 \\
\hline
\end{tabular}

\begin{tabular}{|c|c|c|c|}
\hline Total Area & 155.88 & Total I $x x$ & 396294 \\
\hline
\end{tabular}




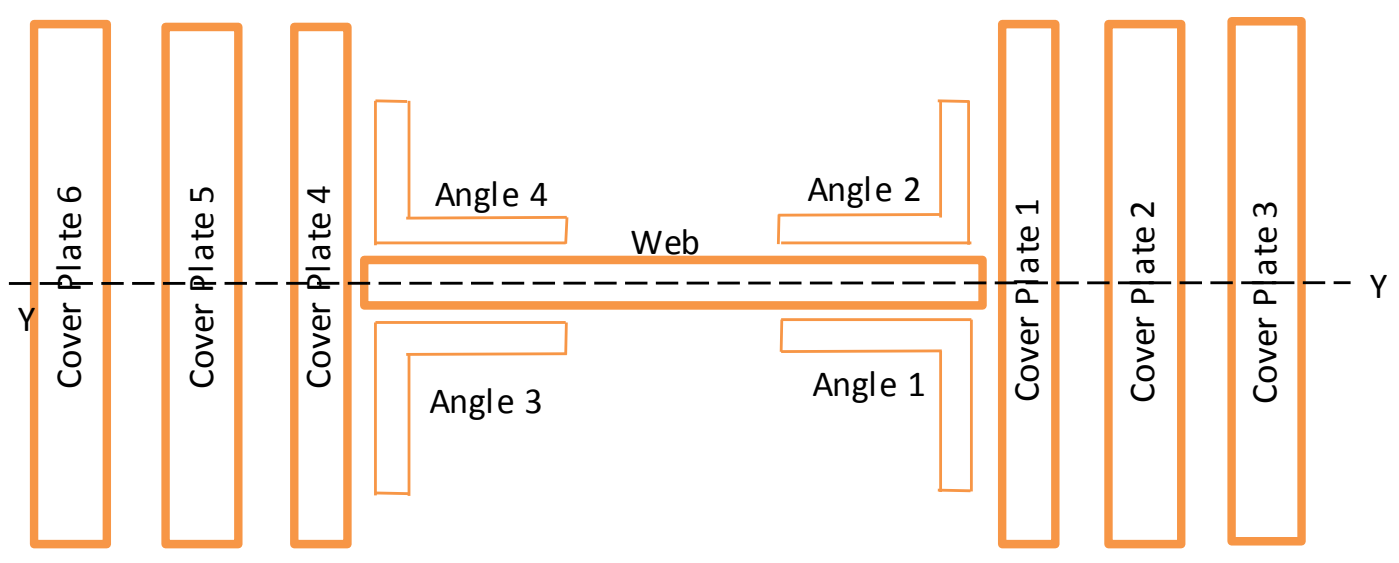

Moment Of Inertia - Weak Axis - Units (inches)

\begin{tabular}{|l|r|r|r|r|r|c|}
\hline Component & \multicolumn{1}{|l|}{ Base } & \multicolumn{1}{l|}{ Height } & \multicolumn{1}{l|}{ Area } & \multicolumn{1}{c|}{$\mathbf{Y}$} & $\mathbf{I}_{\mathbf{0}}$ & $\mathbf{I}_{\mathbf{x x}}$ \\
\hline Web & 114.25 & 0.4375 & 49.98438 & 0 & 0.797277 & 0.797277 \\
\hline Cover Plate 1 & 0.59375 & 18 & 10.6875 & 0 & 288.5625 & 288.5625 \\
\hline Cover Plate 2 & 0.59375 & 18 & 10.6875 & 0 & 288.5625 & 288.5625 \\
\hline Cover Plate 3 & 0.59375 & 18 & 10.6875 & 0 & 288.5625 & 288.5625 \\
\hline Cover Plate 4 & 0.59375 & 18 & 10.6875 & 0 & 288.5625 & 288.5625 \\
\hline Cover Plate 5 & 0.59375 & 18 & 10.6875 & 0 & 288.5625 & 288.5625 \\
\hline Cover Plate 6 & 0.59375 & 18 & 10.6875 & 0 & 288.5625 & 288.5625 \\
\hline Horizontal leg of angle 1 & 7.25 & 0.6875 & 4.984375 & -0.5625 & 0.196325 & 1.773412 \\
\hline Vertical leg of angle 1 & 0.6875 & 7.9375 & 5.457031 & -4.1875 & 28.65119 & 124.3411 \\
\hline Horizontal leg of angle 2 & 7.25 & 0.6875 & 4.984375 & 0.5625 & 0.196325 & 1.773412 \\
\hline Vertical leg of angle 2 & 0.6875 & 7.9375 & 5.457031 & 4.1875 & 28.65119 & 124.3411 \\
\hline Horizontal leg of angle 3 & 7.25 & 0.6875 & 4.984375 & -0.5625 & 0.196325 & 1.773412 \\
\hline Vertical leg of angle 3 & 0.6875 & 7.9375 & 5.457031 & -4.1875 & 28.65119 & 124.3411 \\
\hline Horizontal leg of angle 4 & 7.25 & 0.6875 & 4.984375 & 0.5625 & 0.196325 & 1.773412 \\
\hline Vertical leg of angle 4 & 0.6875 & 7.9375 & 5.457031 & 4.1875 & 28.65119 & 124.3411 \\
\hline
\end{tabular}

\begin{tabular}{|l|l|}
\hline Total & 2237 \\
\hline
\end{tabular}

$$
\begin{aligned}
\mathrm{I}_{\mathrm{yy}}= & 6 *\left(\frac{0.6 * 18^{3}}{12}\right)+4 *\left[\left(\frac{7.94^{3} * 0.6875}{12}\right)+\left((7.94 * 0.6875) *\left(\left(\frac{0.4375}{2}\right)+\frac{7.94}{2}\right)\right)^{2}\right] & \\
& +4 *\left((7.25 * 0.6875)\left(\frac{0.4375}{2}+\frac{0.6875}{2}\right)^{2}\right)+\frac{114.25}{12} *(0.4375)^{3}= & 2237 \mathrm{in}^{4}
\end{aligned}
$$


$\mathbf{2 5 \%}$ section loss - (Thickness of top and bottom cover plates, length of cover plates, thickness of web and thickness of angles all reduced by $25 \%$ ).

Moment of Inertia - Strong Axis - (Units- Inches)

Web

\begin{tabular}{|c|c|c|c|c|c|}
\hline Base & Height & Area & $Y$ & $\mathrm{I}_{\mathbf{0}}$ & $\mathrm{I}_{\mathbf{x x}}$ \\
\hline 0.33 & 114.25 & 37.47 & 0 & 40762.54 & 40763 \\
\hline
\end{tabular}

Cover Plate 1

\begin{tabular}{|c|c|c|c|c|c|}
\hline Base & Height & Area & $Y$ & $\mathrm{I}_{\mathbf{0}}$ & $\mathrm{I}_{\mathbf{x x}}$ \\
\hline 13.5 & 0.6 & 8.02 & 57.42 & 0.24 & 26430 \\
\hline
\end{tabular}

Cover Plate 2

\begin{tabular}{|c|c|c|c|c|c|}
\hline Base & Height & Area & $Y$ & I $_{0}$ & $\mathrm{I}_{\mathbf{x x}}$ \\
\hline 13.5 & 0.5 & 6.08 & 57.94 & 0.10 & 20397 \\
\hline
\end{tabular}

Cover Plate 3

\begin{tabular}{|c|c|c|c|c|c|}
\hline Base & Height & Area & $Y$ & $\mathrm{I}_{\mathbf{o}}$ & $\mathrm{I}_{\mathbf{x x}}$ \\
\hline 13.5 & 0.6 & 8.02 & 58.47 & 0.24 & 27399 \\
\hline
\end{tabular}

Cover Plate 4

\begin{tabular}{|c|c|c|c|c|c|}
\hline Base & Height & Area & $Y$ & $\mathrm{I}_{\mathbf{0}}$ & $\mathrm{I}_{\mathbf{x x}}$ \\
\hline 13.5 & 0.6 & 8.02 & -57.42 & 0.24 & 26430 \\
\hline
\end{tabular}

Cover Plate 5

\begin{tabular}{|c|c|c|c|c|c|}
\hline Base & Height & Area & $Y$ & $\mathrm{I}_{\mathrm{o}}$ & $\mathrm{I}_{\mathbf{x x}}$ \\
\hline 13.5 & 0.6 & 8.02 & -58.02 & 0.24 & 26979 \\
\hline
\end{tabular}

Cover Plate 6

\begin{tabular}{|c|c|c|c|c|c|}
\hline Base & Height & Area & $Y$ & $\mathrm{I}_{\mathrm{o}}$ & $\mathrm{I}_{\mathbf{x x}}$ \\
\hline 18 & 0.5 & 8.10 & -58.54 & 0.14 & 27756 \\
\hline
\end{tabular}

\begin{tabular}{|c|c|c|c|c|c|c|}
\hline Base & Height & Area & $Y$ & $I_{0}$ & $I_{\mathbf{x x}}$ & Component \\
\hline 7.94 & 0.52 & 4.09 & 56.87 & 0.09 & 13235 & Horizontal leg of angle 1 \\
\hline 0.52 & 7.25 & 3.74 & 52.98 & 16.37 & 10511 & Vertical leg of angle 1 \\
\hline 7.94 & 0.52 & 4.09 & 56.87 & 0.09 & 13235 & Horizontal leg of angle 2 \\
\hline 0.52 & 7.25 & 3.74 & 52.98 & 16.37 & 10511 & Vertical leg of angle 2 \\
\hline 7.94 & 0.52 & 4.09 & -56.87 & 0.09 & 13235 & Horizontal leg of angle 3 \\
\hline 0.52 & 7.25 & 3.74 & -52.98 & 16.37 & 10511 & Vertical leg of angle 3 \\
\hline 7.94 & 0.52 & 4.09 & -56.87 & 0.09 & 13235 & Horizontal leg of angle 4 \\
\hline 0.52 & 7.25 & 3.74 & -52.98 & 16.37 & 10511 & Vertical leg of angle 4 \\
\hline
\end{tabular}

\begin{tabular}{|c|c|c|c|}
\hline Total Area & 115.03 & Total Ixx & 291136 \\
\hline
\end{tabular}

$\mathrm{S}_{\mathrm{X}-25 \% \text { section loss }}=5096.471$ 


$\begin{array}{rll}\text { Tie width: } & \mathrm{W}_{\mathrm{t}}= & 8 \mathrm{in} \\ \text { Tie Height: } & \mathrm{h}_{\mathrm{t}}= & 12 \mathrm{in} \\ & \mathrm{S}_{\mathrm{t}}= & 12 \mathrm{in} \\ \text { Tie Length: } & \mathrm{L}_{\mathrm{t}}= & 10 \mathrm{ft} \\ \text { Tie Density: } & \mathrm{r}_{\mathrm{t}}= & 60 \mathrm{lb} / \mathrm{ft}^{3}\end{array}$

\section{Dead Loads:}

\begin{tabular}{|c|c|c|c|c|}
\hline Track rails, inside guide rail \& fastening: & $\mathrm{dl}_{\text {track }}=$ & & & $200 \mathrm{lb} / \mathrm{ft}$ \\
\hline Ties: & $\mathrm{dl}_{\text {ties }}=$ & $\frac{W_{t} * h_{t} * L_{t} * \gamma_{t}}{S_{t}}$ & $=$ & $400 \mathrm{lb} / \mathrm{ft}$ \\
\hline Guard Timber: & $\mathrm{dl}_{\mathrm{gt}}=$ & $\left(2 * 4 * 8 * \gamma_{t}\right)$ & $=$ & $26.66667 \mathrm{lb} / \mathrm{ft}$ \\
\hline Track system Dead Load : & $W_{D L}=$ & $\mathrm{dl}_{\text {track }}+\mathrm{dl}_{\text {ties }}+\mathrm{dl}_{\mathrm{gt}}$ & $=$ & $626.6667 \mathrm{lb} /$ \\
\hline
\end{tabular}

RISA automatically accounts for the self weight of the stringers, floor beams and girders

\section{Live Loads:}

Impact

Without Hammer Blow:

$$
\text { Length }>80 \text { feet }
$$

\section{AREMA 1.3.5c (1)}

$$
\begin{aligned}
I_{m} & =16+\frac{600}{L-30}=24.9 \\
\therefore I_{m} & =24.9 \%
\end{aligned}
$$

\section{Impact Load Redutions:}

For Train Speeds Below $60 \mathrm{mph}$, other than truss spans with hammer blow, the effect of impact shall be multiplied by the following factor:

$$
\begin{aligned}
& \mathrm{I}_{\text {red }}=\max \left[1-\left(\frac{0.8}{2500}\right) *(60-S)^{2}, 0.2\right] \\
& \mathrm{I}=\quad \mathrm{I}_{\mathrm{m}} * \mathrm{I}_{\text {red }}=\quad 4.990 \%
\end{aligned}
$$

Rocking Effect:

AREMA 1.3.5d

$20 \%$ of the wheel load without impact, applied as a vertical force couple

$$
\mathrm{RE}=\quad 20 \%
$$

\section{Centrifugal Force:}

AREMA 1.3.6
$\mathrm{CF}_{\mathrm{V}}=$
0 No curve 


\section{THROUGH GIRDER:}

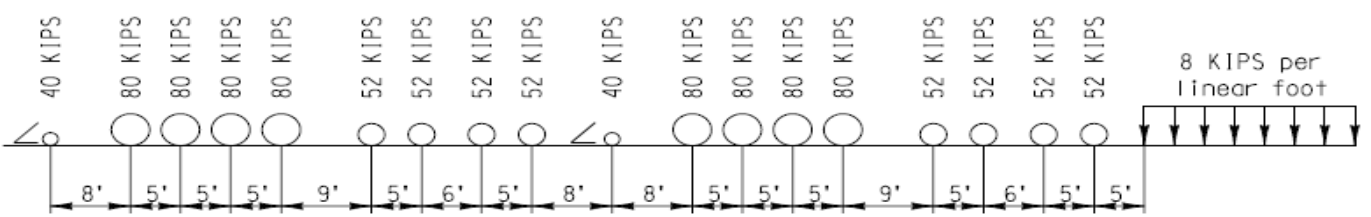

Fig.A1, Cooper E 80 loading.

\section{Computation of Stresses:}

AREMA 3.1.5

Live Load Shears and Moments are found using RISA software.

Live Load Moment:

$$
M_{\mathrm{LL}}=\quad 6060.4 \mathrm{ft}-\mathrm{kips}
$$

$\mathrm{M}_{\mathrm{LL} \_\mathrm{E} 80}=\quad M_{L L}\left(1+\frac{I}{100}+\frac{R E}{100}+\frac{C F_{V}}{100}\right)=$

$6060.3\left(1+\frac{4.9}{100}+\frac{20}{100}+\frac{0}{100}\right)=$

7574.9 ft-kips

Rating Factor $=\mathrm{RF}_{\mathrm{n}} \mathrm{Or} \mathrm{RF}_{\mathrm{m}}=$

Allowable Stress $\left(F_{b n}, F_{v n}\right.$ or $\left.F_{b m}, F_{v m}\right)$-Dead Load Stress $\left(F_{D L}\right)$ Live Load Stress $\left(f_{L L}, f_{V L}\right)$

Moment Ratings :

\begin{tabular}{|c|c|c|c|}
\hline Moment (M) & Unfactored (Kip-ft) & Factored (Kip-ft) & Stress (ksi) \\
\hline Dead Load & 1192.3 & N/A & 2.127 \\
\hline Live Load & 6060.4 & 7574.9 & 13.511 \\
\hline
\end{tabular}

\begin{tabular}{|l|c|c|}
\hline Moment Rating & Normal & Maximum \\
\hline Rating Factor & 1.04 & 1.62 \\
\hline Cooper E Rating & 83.0 & 129.5 \\
\hline
\end{tabular}

\section{Shear Ratings:}

Shear values per stringer:

$\mathrm{V}_{\mathrm{DL}}=\quad 45.6 \mathrm{Kips}$

$\mathrm{V}_{\mathrm{LL}}=\quad 285.4 \mathrm{Kips}$

(Obtained from RISA)

$$
\mathrm{V}_{\mathrm{LL} \_88 \mathrm{O}}=\frac{V_{L L}}{n}\left(1+\frac{I}{100}+\frac{R E}{100}+\frac{C F_{V}}{100}\right)=\frac{235.4}{1}\left(1+\frac{7.904}{100}+\frac{20}{100}+\frac{0}{100}\right)=356.8 \text { Kips }
$$

\begin{tabular}{|c|c|c|c|c|c|}
\hline$V_{L_{L} \sigma}=$ & $\frac{V_{L L}}{\left(D-\left(2 * t_{f}\right)\right) * t_{w}}=$ & 7.22 & ksi & $\begin{aligned} W_{\text {eb }}^{\text {depth }} & = \\
\text { Web }_{\text {thick }} & =\end{aligned}$ & $\begin{array}{r}117.81 \text { inches } \\
0.44 \text { inches }\end{array}$ \\
\hline$V_{D_{L} \sigma}=$ & $\frac{V_{D L}}{\left(D-\left(2 * t_{f}\right)\right) * t_{w}}=$ & 0.923 & ksi & $\begin{array}{r}\text { Web depth between flanges }= \\
\text { Flange } \\
\text { Thickness }\end{array}$ & $\begin{array}{r}112.87 \text { inches } \\
2.469 \text { inches }\end{array}$ \\
\hline
\end{tabular}

\section{SHEAR RATING:}

$$
\begin{aligned}
& \mathrm{RF}_{\mathrm{Vn}}=\frac{\mathrm{F}_{\mathrm{Vn}}-\mathrm{V}_{\mathrm{DL}_{-} \sigma}}{\mathrm{V}_{\mathrm{LL} \_}} * 80=\frac{10.5-0 . .923}{5.96} * 80= \\
& \mathrm{RF}_{\mathrm{Vm}}=\frac{\mathrm{F}_{\mathrm{Vm}-\mathrm{V}_{\mathrm{DL}_{-} \sigma}} * 80=\frac{18-0.923}{5.96} * 80=}{\mathrm{V}_{\mathrm{LL}_{-} \sigma}}=
\end{aligned}
$$

$\begin{array}{lll}\text { Normal } & 106.0 & \text { or E } 106.6 \\ \text { Maximum } & & \\ & 189.1 & \text { or E } 189.1\end{array}$




\section{Equipment Loads:}

Load 1 - Freight Railcar (286 Kips):

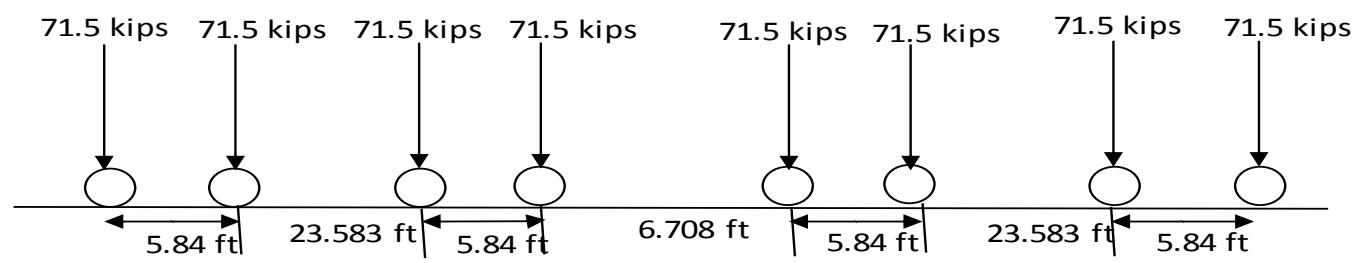

$286 \mathrm{~K}$ freight railcar Gross Rail Load 286000 lbs 71.5 Kips Axle weight

Fig. A2, 286 Kips Freight Car, Axle loads and distance between axles

\section{Load 2 - GP 38 Locomotive:}

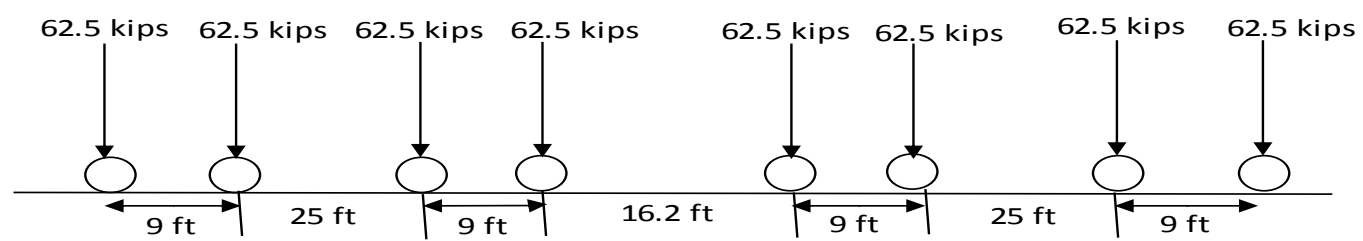

GP-38

Gross Rail Load 250000 Lbs

62.5 Kips Axle weight

Fig. A3, GP 38 Locomotive, Axle loads and distance between axles

\section{Load 3 - GP 9 Locomotive:}

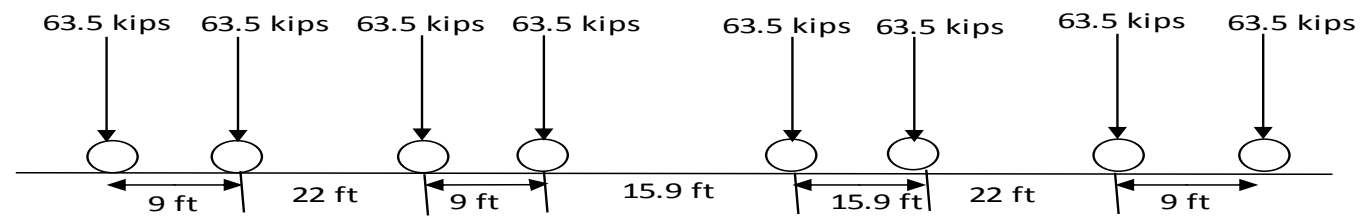

GP 9

Gross Rail Load 254000 Lbs

63.5 Kips Axle weight

Figure A4, GP 9 Locomitive, Axle Loads and Distance Between Axles

\section{Load 4 - WM 82 Locomotive:}

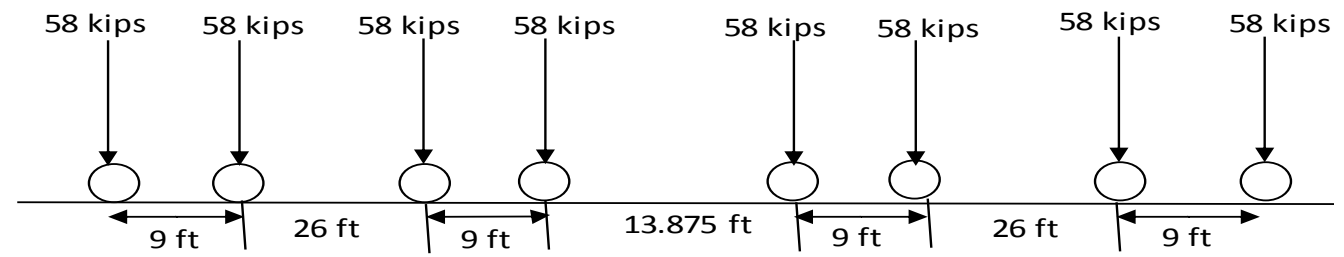

WM-82

58 Kips Axle weight

Figure A5, WM 82 Locomitive, Axle Loads and Distance Between Axles 


\section{Eqvuivalent Cooper E Ratings (Moment):}

Live Load Moments And Shears are Obtained from RISA Software.

$$
\mathrm{M}_{\mathrm{LL}_{-} \text {Factored }}=\quad M_{L L}\left(1+\frac{I}{100}+\frac{R E}{100}+\frac{C F_{V}}{100}\right) \quad \mathrm{V}_{\mathrm{LL}_{-} \text {Factored }}=\frac{V_{L L}}{n}\left(1+\frac{I}{100}+\frac{R E}{100}+\frac{C F_{V}}{100}\right)
$$

Equipment Load $=\frac{\text { Equipment }(286 \text { Kips }, \text { GP 38, GP 9, WM 82) Live Load Moment or Shear }}{E 80 \text { Live Load Moment or Shear }} 80$

\begin{tabular}{|c|c|c|c|c|}
\cline { 2 - 5 } \multicolumn{1}{c|}{} & 1 & 2 & 3 & 4 \\
\hline Live Load & 286 Kips & GP 38 & GP 9 & WM 82 \\
\hline Moment (Unfactored) (Kip-ft) & 4094.20 & 2571.90 & 2676.70 & 2437.70 \\
\hline Moment (factored) (Kip-ft) & 5117.34 & 3214.62 & 3345.61 & 3046.88 \\
\hline Equivalent Cooper Load & 54.05 & 33.95 & 35.33 & 32.18 \\
\hline Equivalent < Normal ? & OK & OK & OK & OK \\
\hline
\end{tabular}

\begin{tabular}{|c|c|c|c|c|}
\hline Live Load & 286 Kips & GP 38 & GP 9 & WM 82 \\
\hline Shear (Unfactored) (Kip-ft) & 200.50 & 122.20 & 126.90 & 115.80 \\
\hline Shear (factored) (Kip-ft) & 250.60 & 152.74 & 158.61 & 144.74 \\
\hline Equivalent Cooper Load & 56.19 & 34.25 & 35.57 & 32.45 \\
\hline Equivalent < Normal ? & OK & OK & OK & OK \\
\hline
\end{tabular}




\section{APPENDIX - B}




\section{LOAD RATING ANALYSIS - FLOOR BEAM}

\section{FLOOR BEAM:}

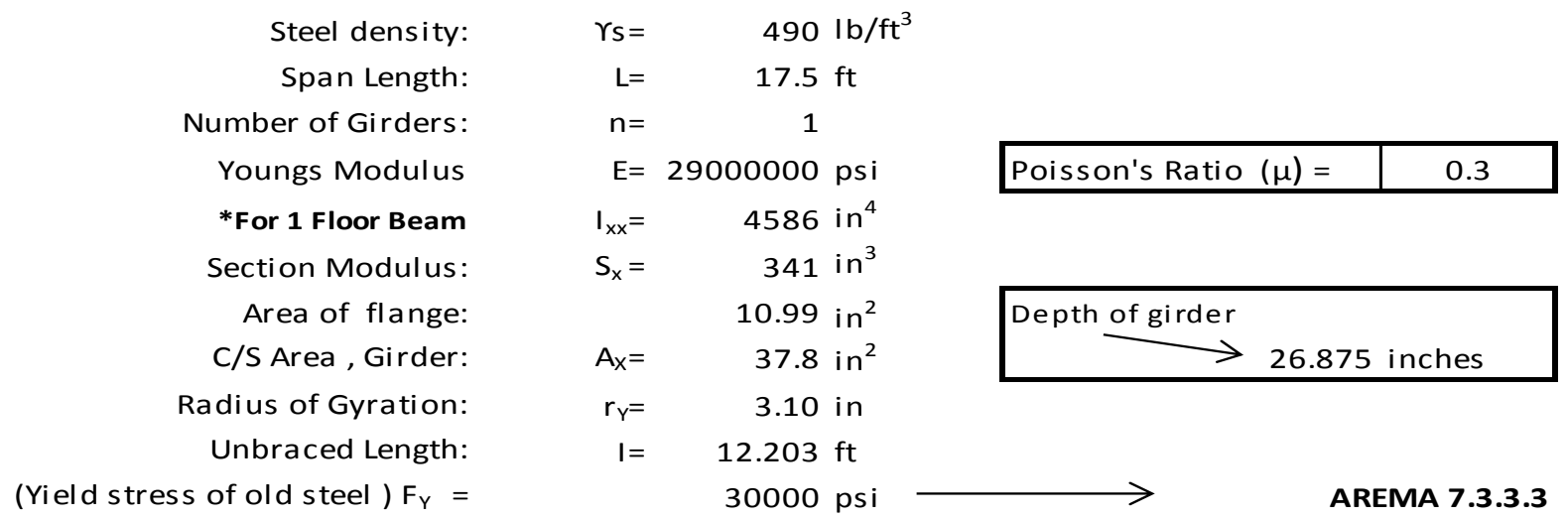

\section{Allowable Stresses:}

Normal Rating :

AREMA Table 15-1-11

Tension: $\quad \mathrm{F}_{\mathrm{bpn}}$ :-

$0.55^{*} \mathrm{~F}_{\mathrm{Y}}=16500 \mathrm{psi}$

$16.5 \mathrm{ksi}$

Compression : $\quad$ Choose Maximum of $\mathrm{F}_{\mathrm{bnn} 1}, \mathrm{~F}_{\mathrm{bnn} 2}$

$$
\begin{aligned}
& \mathrm{F}_{\mathrm{bnn1}:-} \quad F_{b p n}-\frac{0.55 *\left(F_{Y}\right)^{2}}{6.3 * \pi^{2} * 29 * 10^{6}} * \frac{L^{2}}{\left(r_{Y}\right)^{2}}=16500-\frac{0.55 *(30000)^{2}}{6.3 * \pi^{2} * 29 * 10^{6}} * \frac{(11.25 * 12)^{2}}{(3.03)^{2}}= \\
& \mathrm{F}_{\mathrm{bnn} 2}:- \\
& \frac{0.131 * \pi * E}{\frac{L . d \sqrt{1+\mu}}{A_{f}}}=\frac{0.131 * \pi * 29 * 10^{6}}{\frac{17.5 * 12 * 26.875 * \sqrt{1+0.3}}{10.99}} \\
& 20366.30 \text { psi }
\end{aligned}
$$

\begin{tabular}{|l|l|}
\hline 15237 & psi \\
\hline 15.24 & ksi \\
\hline
\end{tabular}

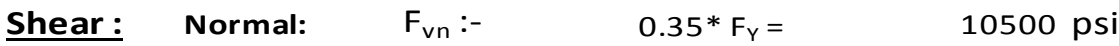

\section{Maximum Rating :}

Tension: $\quad \mathrm{F}_{\mathrm{bpm}}$ :-

\section{AREMA Ch.15 - 7.3.3.3 \& Table 15-7-1}

$0.8^{*} \mathrm{~F}_{\mathrm{Y}}=\quad 24000 \mathrm{psi}$

24 ksi

Compression: $\quad$ Choose Maximum of $F_{b n m 1}, F_{b n m 2}$

$$
\begin{aligned}
& \mathrm{F}_{\mathrm{bnm1}}=F_{b p m}-\frac{0.8 *\left(F_{Y}\right)^{2}}{1.8 * 10^{9}} * \frac{I^{2}}{\left(r_{Y}\right)^{2}}=24000-\frac{0.8 *(30000)^{2}}{1.8 * 10^{9}} * \frac{(11.25 * 12)^{2}}{(3.28)^{2}}=\begin{array}{r|r|l|}
24000 & \mathrm{psi} \\
\hline
\end{array} \\
& \mathrm{F}_{\mathrm{bnm2}}=\frac{0.8 * F_{Y} * 10500000}{\frac{L . d * 0.55 * F_{Y}}{A_{f}}}=\frac{0.8 * 30000 * 10500000}{\frac{17.5 * 12 * d * 0.55 * 30000}{10.99}}=\begin{array}{r|r|r|}
29730 & \mathrm{psi} \\
\hline 29.730 & \mathrm{ksi} \\
\hline
\end{array} \\
& \text { If } F_{\mathrm{bnm2}} \text { Exceeds } 0.8 \mathrm{~F}_{\mathrm{Y}} \text {, use } \mathrm{F}_{\mathrm{bnm2}}=\quad 0.8 \mathrm{~F}_{\mathbf{Y}}=\quad 24000 \mathrm{psi}
\end{aligned}
$$

Shear: Maximum: $F_{\mathrm{vm}}:-\quad 0.75 * 0.8 \mathrm{~F}_{\mathrm{Y}}=$ 18000 psi 


\section{Allowable Stresses for Rating:}

\begin{tabular}{|l|c|l|c|c|}
\hline & Normal & \multicolumn{1}{|c|}{ Units } & Maximum & Units \\
\hline Bending & 16500 & $\mathrm{psi}$ & 24000 & $\mathrm{psi}$ \\
\hline Shear & 10500 & $\mathrm{psi}$ & 18000 & $\mathrm{psi}$ \\
\hline
\end{tabular}

$\mathbf{F}_{\text {bpn:- }}$ Bending stress in tension, normal

$\mathbf{F}_{\text {bnn }}$ :- Bending stress in compression, normal

$\mathbf{F}_{\text {bpm:- }}$ Bending stress in tension, maximul

$\mathbf{F}_{\text {bnm:- }}$ : Bending stress in compression, maximum

$\mathbf{F}_{\text {bnm1 } 1}, \mathbf{F}_{\mathrm{bnm} 2}$ :- $\quad$ Bending stresses in extreme fibres in compression, Maximum

$\mathbf{F}_{\text {bnn1 }}, \mathbf{F}_{\text {bnn2 }}$ :- $\quad$ Bending stresses in extreme fibres in compression, Normal

$\mathbf{F}_{\mathrm{V} n}$ :- Shear stress, normal $\quad \mathbf{F}_{\mathrm{Vm}}$ :- Shear stress, maximum 
*All the measurements are checked by WVU-CFC during an inspection in May-2014

WEB:

$\begin{aligned} \text { Web }_{\text {depth }}= & W_{d}= & 25.31 & \text { inches } \\ \text { Web }_{\text {thickness }}= & W_{t}= & 0.63 & \text { inches }\end{aligned}$

FLANGE:

$\begin{array}{rccr}\text { Flange }_{\text {Width }}= & \mathrm{F}_{\mathrm{W}}= & 14.06 & \text { inches } \\ \text { Flange }_{\text {Thickness }}= & \mathrm{F}_{\mathrm{t}}= & 0.78 & \text { inches }\end{array}$

Area of cross section:

$$
\begin{array}{lc}
A_{x}= & (25.31 * 0.63)+[2 * 14.06 * 0.78] \\
A_{x}= & 37.8 \mathrm{in}^{2}
\end{array}
$$

Moment of inertia:

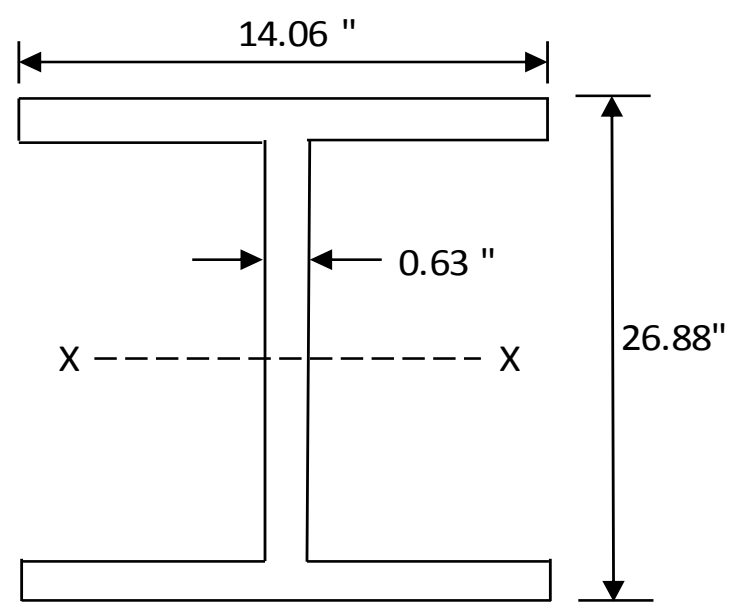

$$
\begin{array}{ll}
\mathrm{I}_{\mathrm{xx}}= & \left(\frac{0.63 * 25.42^{3}}{12}\right)+2 *\left[\left(\frac{14.06 * 0.78^{3}}{12}\right)+\left((14.06 * 0.78) *\left(\frac{25.42}{2}+\frac{0.78}{2}\right)^{2}\right)\right] \\
\mathrm{I}_{\mathrm{xx}}= & 4586 \mathrm{in}^{4}
\end{array}
$$

\begin{tabular}{|c|c|c|c|c|c|c|}
\hline Component & Width & Depth & Area & $\mathrm{Y}$ & $I_{o}$ & $I_{x x}$ \\
\hline Flange (Top) & 14.06 & 0.78 & 10.99 & 13.05 & 0.56 & 1870.66 \\
\hline Flange (Bottom) & 14.06 & 0.78 & 10.99 & -13.05 & 0.56 & 1870.66 \\
\hline Web & 0.63 & 25.31 & 15.82 & 0 & 844.70 & 844.70 \\
\hline
\end{tabular}

\begin{tabular}{|l|l|}
\hline TOTAL & 4586.03 \\
\hline
\end{tabular}

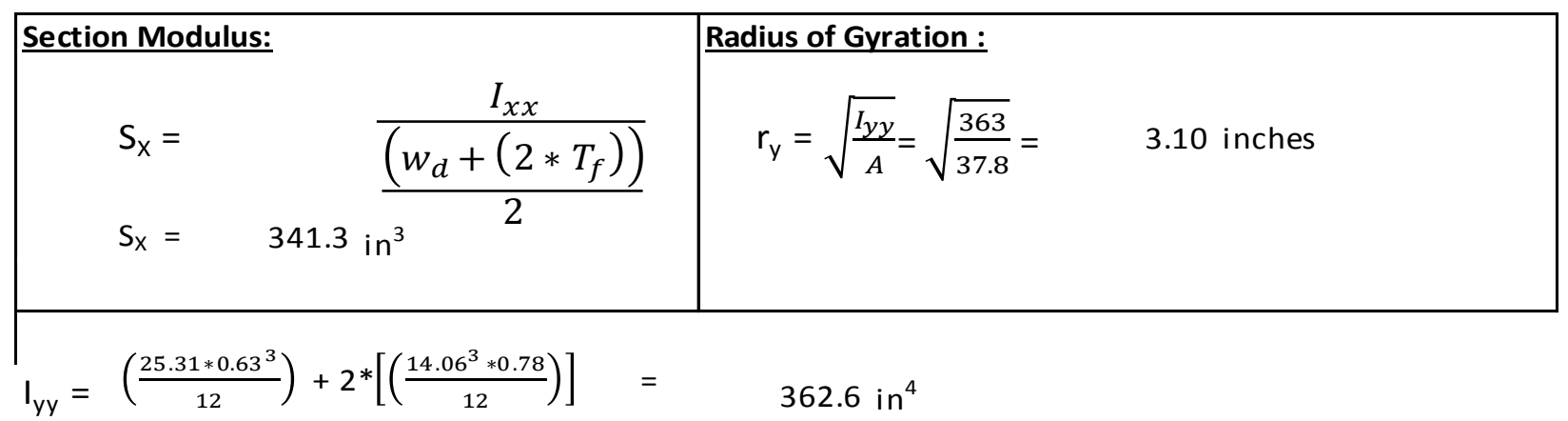


Tie Size and Spacing

$\begin{array}{rcc}\text { Tie width: } & \mathrm{W}_{\mathrm{t}}= & 8 \mathrm{in} \\ \text { Tie Height: } & \mathrm{h}_{\mathrm{t}}= & 12 \mathrm{in} \\ \text { Tie Spacing: } & \mathrm{S}_{\mathrm{t}}= & 12 \mathrm{in} \\ \text { Tie Length: } & \mathrm{L}_{\mathrm{t}}= & 10 \mathrm{ft} \\ \text { Tie Density: } & \mathrm{r}_{\mathrm{t}}= & 60 \mathrm{lb} / \mathrm{ft}^{3}\end{array}$

\section{Dead Loads:}

\begin{tabular}{|c|c|c|c|c|}
\hline Track rails, inside guide rail \& fastening: & $\mathrm{dl}_{\text {track }}=$ & & & $200 \mathrm{lb} / \mathrm{ft}$ \\
\hline Ties: & $\mathrm{dl}_{\text {ties }}=$ & $\frac{W_{t^{*}} h_{t^{*} L_{t^{*}}} \gamma_{t}}{S_{t}} * 1$ & $=$ & $400.0 \mathrm{lb} / \mathrm{ft}$ \\
\hline Guard Timber: & $\mathrm{dl}_{\mathrm{gt}}=$ & $\left(2 * 4 * 8 * \gamma_{t}\right) * I$ & $=$ & $26.67 \mathrm{lb} / \mathrm{ft}$ \\
\hline Track system Dead Load : & $\mathrm{W}_{\mathrm{DL}}=$ & $+\mathrm{dl}_{\text {ties }}+\mathrm{dl}_{\mathrm{gt}}$ & & $626.7 \mathrm{lb} / \mathrm{ft}$ \\
\hline
\end{tabular}

RISA Automatically accounts for the self weight of the stringers and floor beams. 


\section{Live Loads:}

Impact Load :

AREMA 1.3.5c (1)

Length $<80$ feet

$$
\begin{gathered}
I_{m}=40-\frac{3 * L^{2}}{1600}= \\
\therefore I_{m}=\quad 39.43 \%
\end{gathered}
$$

Impact Load Redutions:

AREMA Ch. 15 - 7.3.2.3 and Ch. 15 - 1.3.5(1)(a)

$$
\begin{aligned}
I_{\text {red }} & =\max \left[1-\left(\frac{0.8}{2500}\right) *(60-S)^{2}, 0.2\right] \\
I & =I_{\mathrm{m}} * \mathrm{I}_{\text {red }}=\quad 7.89 \%
\end{aligned}
$$

Rocking Effect:

$$
\mathrm{RE}=\quad 20 \%
$$

Centrifugal Force:

AREMA Ch. 15 - 1.3.5(d)

$$
\mathrm{CF}_{\mathrm{V}}=\text { Centrifugal Force }=\quad 0 \%
$$

AREMA Ch.15 - 1.3.6 


\section{Computation of Stresses:}

Live Load Shears and Moments are found using RISA software.

Live Load Moment:

$$
\mathrm{M}_{\mathrm{LL}}=\quad 403.5 \quad \mathrm{ft}-\mathrm{kips}
$$

$\mathrm{M}_{\mathrm{LL}_{-} \mathrm{E} 80}=\quad M_{L L}\left(1+\frac{I}{100}+\frac{R E}{100}+\frac{C F_{V}}{100}\right)=\quad 403.5\left(1+\frac{7.904}{100}+\frac{20}{100}+\frac{0}{100}\right)=\quad 516.0 \mathrm{ft}-\mathrm{kips}$

Rating Factor $=\mathrm{RF}_{\mathrm{n}} \operatorname{Or~RF}_{\mathrm{m}}=\frac{\text { AllowableStress }\left(F_{b n}, F_{v n} \text { or } F_{b m}, F_{v m}\right)-\operatorname{Dead} \operatorname{Load} \operatorname{Stress}\left(F_{D L}\right)}{\operatorname{Live~Load~StresS}\left(f_{L L}, f_{V L}\right)}$

Moment Ratings:

\begin{tabular}{|l|c|c|c|}
\hline Moment & Unfactored (Kip-ft) & Factored (Kip-ft) & Stress (ksi) \\
\hline Dead Load & 25.868 & N/A & 0.910 \\
\hline Live Load & 403.5 & 516.0 & 18.144 \\
\hline
\end{tabular}

\begin{tabular}{|l|c|c|}
\hline Moment Rating & Normal & Maximum \\
\hline Rating Factor & 0.86 & 1.27 \\
\hline Cooper E Rating & 68.7 & 101.8 \\
\hline
\end{tabular}

\section{Shear Ratings:}

Shear values per stringer:

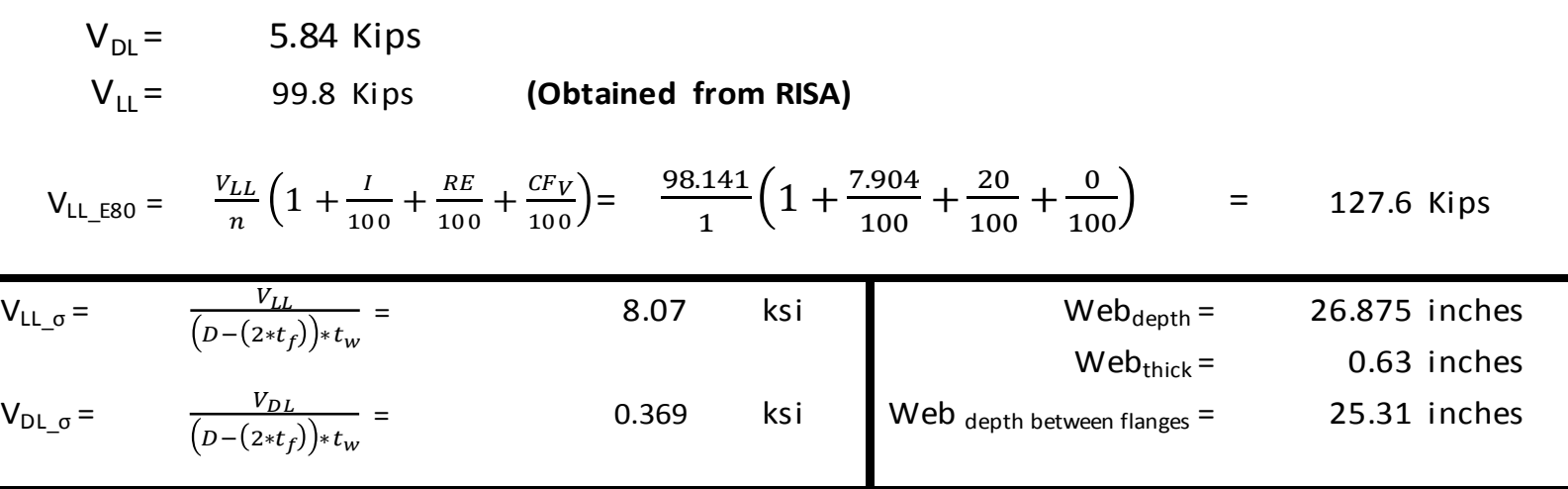

\section{RATING:}

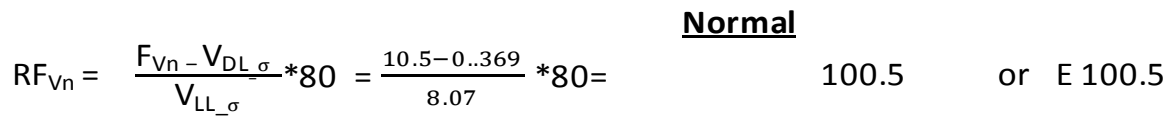

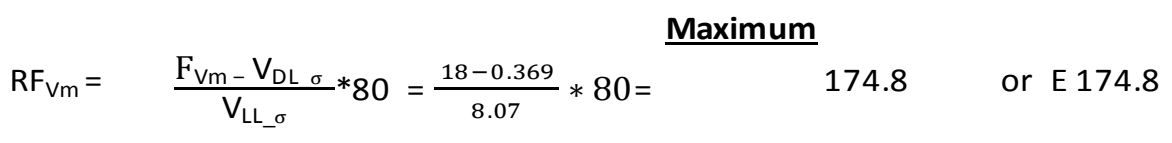




\section{Eqvuivalent Cooper E Ratings (Moment):}

Live Load Moments And Shears are Obtained from RISA Software.

$$
\mathrm{M}_{\mathrm{LL} \_ \text {Factored }}=\quad M_{L L}\left(1+\frac{I}{100}+\frac{R E}{100}+\frac{C F_{V}}{100}\right) \quad \mathrm{V}_{\mathrm{LL} \_ \text {Factored }}=\frac{V_{L L}}{n}\left(1+\frac{I}{100}+\frac{R E}{100}+\frac{C F_{V}}{100}\right)
$$

Equipment Load $=\quad \frac{\text { Equipment }(286 \text { Kips , GP 38, GP 9, WM 82) Live Load Moment or Shear }}{E 80 \text { Live Load Moment or Shear }} * 80$

\begin{tabular}{|c|c|c|c|c|}
\cline { 2 - 5 } \multicolumn{1}{c|}{} & 1 & 2 & 3 & 4 \\
\hline Live Load & 286 Kips & GP 38 & GP 9 & WM 82 \\
\hline Moment (Unfactored) (Kip-ft) & 302.80 & 172.30 & 175.60 & 162.30 \\
\hline Moment (factored) (Kip-ft) & 387.24 & 220.35 & 224.57 & 207.56 \\
\hline Equivalent Cooper Load & 60.03 & 34.16 & 34.82 & 32.18 \\
\hline Equivalent < Normal ? & OK & OK & OK & OK \\
\hline
\end{tabular}

\begin{tabular}{|c|c|c|c|c|}
\hline Live Load & 286 Kips & GP 38 & GP 9 & WM 82 \\
\hline Shear (Unfactored) (Kip-ft) & 75.00 & 43.40 & 44.10 & 40.30 \\
\hline Shear (factored) (Kip-ft) & 95.91 & 55.50 & 56.40 & 51.54 \\
\hline Equivalent Cooper Load & 60.12 & 34.79 & 35.35 & 32.30 \\
\hline Equivalent < Normal ? & OK & OK & OK & OK \\
\hline
\end{tabular}


APPENDIX - C 


\section{LOAD RATING ANALYSIS - STRINGER (Bridge 1.4)}

\section{STRINGER:}

$\begin{array}{rrc}\text { Steel density: } & \mathrm{YS}_{\mathrm{S}}= & 490 \mathrm{lb} / \mathrm{ft}^{3} \\ \text { Span Length: } & \mathrm{L}= & 12.21 \mathrm{ft} \\ \text { Number of Girders: } & \mathrm{n}= & 1 \\ \text { Degree of Curve: } & \mathrm{D}= & 0 \text { degree } \\ \text { for 1 stringer } & \mathrm{I}_{\mathrm{Xx}}= & 1145.8 \\ \text { Section Modulus: } & \mathrm{S}_{\mathrm{X}}= & 114.6 \mathrm{in}^{3} \\ \text { Depth of girder } & \mathrm{d}= & 20 \\ \text { C/S Area Girder: } & \mathrm{A}_{\mathrm{X}}= & 19.04 \\ \text { Radius of Gyration: } & \mathrm{r}_{\mathrm{Y}}= & 1.18 \mathrm{in} \\ & & \\ \text { (Yield stress ) } \mathrm{F}_{\mathrm{Y}}= & & 30000 \mathrm{psi} \\ \text { Youngs Modulus } & \mathrm{E}= & 29000000 \mathrm{psi}^{-} \\ & \mathrm{I}_{\mathrm{yy}}= & 26.7 \mathrm{in}^{4} \\ \text { Area of flange: } & \mathrm{A}_{\mathrm{F}}= & 4.78 \mathrm{in}^{2}\end{array}$

\begin{tabular}{|l|l|}
\hline Poisson's Ratio $(\mu)=$ & 0.3 \\
\hline
\end{tabular}

Data From AISC Historic Database

\section{Allowable Stresses :}

\section{Normal Rating :}

Tension:

$F_{\text {bpn }}:-$
AREMA Table 15-1-11

$0.55^{*} \mathrm{~F}_{\mathrm{Y}}=$\begin{tabular}{|r|l|}
\hline 16500 & $\mathrm{psi}$ \\
\hline 16.5 & $\mathrm{ksi}$ \\
\hline
\end{tabular}

Choose Maximum of $F_{b n n 1}, F_{b n n 2}$

Compression :

$$
\mathrm{F}_{\mathrm{bnn} 1:-} \quad F_{b p n}-\frac{0.55 *\left(F_{Y}\right)^{2}}{6.3 * \pi^{2} * 29 * 10^{6}} * \frac{L^{2}}{\left(r_{Y}\right)^{2}}=16500-\frac{0.55 *(30000)^{2}}{6.3 * \pi^{2} * 29 * 10^{6}} * \frac{(12.21 * 12)^{2}}{(1.18)^{2}}=
$$

\begin{tabular}{|l|l|}
\hline 12295 & psi \\
\hline 12.29 & $\mathrm{ksi}$ \\
\hline
\end{tabular}

$$
\mathrm{F}_{\mathrm{bnn} 2}:-\quad \frac{0.131 * \pi * E}{\frac{L . d \sqrt{1+\mu}}{A_{f}}}=\frac{0.131 * \pi * 29 * 10^{6}}{\frac{12.21 * 12 * 20 * \sqrt{1+0.3}}{4.78}}=
$$

17068.66 psi

If $F_{b n n 2}$ Exceeds $0.55 F_{Y}$, Then use $F_{b n n 2}=$

$0.55 F_{Y}=$ 16500 psi

Shear: Normal: $\quad F_{\mathrm{vn}}$ :-

$0.35 * \mathrm{~F}_{\mathrm{Y}}=$

\begin{tabular}{|c|c|c|c|c|}
\hline \multicolumn{2}{|c|}{ Maximum Rating : } & \multicolumn{3}{|c|}{ AREMA Ch.15 - 7.3.3.3 \& Table } \\
\hline \multirow{2}{*}{ Tension: } & \multirow[t]{2}{*}{$F_{b p m}:-$} & \multirow{2}{*}{$0.8^{*} \mathrm{~F}_{\mathrm{Y}}=$} & 24000 & psi \\
\hline & & & 24 & ksi \\
\hline
\end{tabular}
10500 psi

Compression:

Choose Maximum of $F_{b n m 1}, F_{b n m 2}$

$$
\begin{aligned}
& \mathrm{F}_{\mathrm{bnm1}}=F_{b p m}-\frac{0.8 * F_{Y}}{1.8 * 10^{9}} * \frac{I^{2}}{\left(r_{Y}\right)^{2}}=24000-\frac{0.8 * 30000}{1.8 * 10^{9}} * \frac{(12.21 * 12)^{2}}{(1.18)^{2}}= \\
& \begin{array}{|r|l|}
\hline 24000 & \text { psi } \\
\hline 24 & \text { ksi } \\
\hline
\end{array} \\
& \mathrm{F}_{\mathrm{bnm2}}= \\
& \frac{0.8 * F_{Y} * 10500000}{\frac{L . d * 0.55 * F_{Y}}{A_{f}}}=\frac{0.8 * 30000 * 10500000}{\frac{17.5 * 12 * d * 0.55 * 30000}{4.78}}
\end{aligned}
$$

\begin{tabular}{|l|l|}
\hline 24917 & $\mathrm{psi}$ \\
\hline 24.917 & $\mathrm{ksi}$ \\
\hline
\end{tabular}


If $F_{b n m 2}$ Exceeds $0.8 F_{Y}$, use $F_{b n m 2}=\quad 0.8 F_{Y}=$ 24000 psi

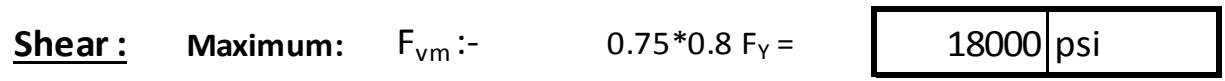

Allowable Stresses for Rating:

\begin{tabular}{|l|c|l|c|l|}
\hline & Normal & \multicolumn{1}{|c|}{ Units } & Maximum & \multicolumn{1}{|c|}{ Units } \\
\hline Bending & 16500 & psi & 24000 & psi \\
\hline Shear & 10500 & psi & 18000 & psi \\
\hline
\end{tabular}

$\mathbf{F}_{\text {bpn:- }}$ Bending stress in tension, normal $\quad \mathbf{F}_{\text {bnn }}$ :- Bending stress in compression, normal

$\mathbf{F}_{\text {bpm: }}$ :- Bending stress, tension, maximum $\quad \mathbf{F}_{\mathbf{b n m}}$ :- Bending stress in compression, maximum

$\mathbf{F}_{\text {bnm1 }}, \mathbf{F}_{\text {bnm: }}$ Bending stresses in extreme fibres in compression, Maximum

$\mathbf{F}_{\text {bnn1 }}, \mathbf{F}_{\text {bnn2 }}$ : Bending stresses in extreme fibres in compression, Normal

$\mathbf{F}_{\mathrm{Vn}}$ :- Shear stress, normal $\quad \mathbf{F}_{\mathrm{Vm}}$ :- Shear stress, maximum

*All the measurements are taken from the AISC Historic Database.

WEB:

$$
\begin{aligned}
& \mathrm{Web}_{\text {depth }}=\quad \mathrm{W}_{\mathrm{d}}= \\
& \text { Web }_{\text {thickness }}=\quad W_{t}=
\end{aligned}
$$

\begin{tabular}{|c|c|c|}
\hline Flange $_{\text {Width }}=$ & $\mathrm{F}_{\mathrm{W}}=$ & 6.25 \\
\hline Flange $_{\text {Thickness-edge }}=$ & $\mathrm{F}_{\mathrm{te}}=$ & 0.58 \\
\hline Flange $_{\text {Thickness@web }}=$ & $F_{t w}=$ & 0.83 \\
\hline Flange $_{\text {Thickness }- \text { AVG }}=$ & $\mathrm{F}_{\mathrm{AVG}}=$ & 0.76 \\
\hline
\end{tabular}

\section{FLANGE:}

$\begin{array}{cc}18.48 & \text { inches } \\ 0.5 & \text { inches } \\ & \\ 6.25 & \text { inches } \\ 0.58 & \text { inches } \\ 0.83 & \text { inches } \\ 0.76 & \text { inches }\end{array}$

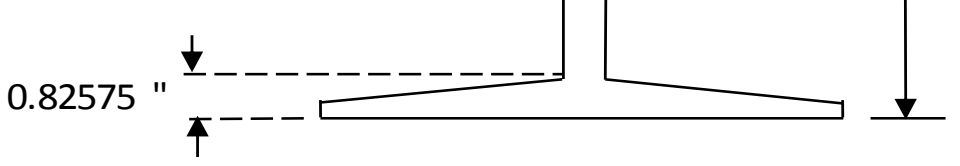


Tie Size and Spacing

$\begin{array}{rcc}\text { Tie width: } & \mathrm{W}_{\mathrm{t}}= & 8 \mathrm{in} \\ \text { Tie Height: } & \mathrm{h}_{\mathrm{t}}= & 12 \mathrm{in} \\ \text { Tie Spacing: } & \mathrm{S}_{\mathrm{t}}= & 12 \mathrm{in} \\ \text { Tie Length: } & \mathrm{L}_{\mathrm{t}}= & 10 \mathrm{ft} \\ \text { Tie Density: } & \mathrm{r}_{\mathrm{t}}= & 60 \mathrm{lb} / \mathrm{ft}^{3}\end{array}$

\section{Dead Loads:}

$$
\text { Ties: } \quad \mathrm{dl}_{\text {ties }}=\frac{W_{t} * h_{t^{*} L_{t} * \gamma_{t}}}{S_{t}}=400.0 \mathrm{lb} / \mathrm{ft}
$$$$
\text { Guard Timber: } \quad \mathrm{dl}_{\mathrm{gt}}=\left(2 * 4 * 8 * \gamma_{t}\right)=26.66666667 \mathrm{lb} / \mathrm{ft}
$$$$
\text { Track system Dead Load : } \quad \mathrm{W}_{\mathrm{DL}}=\mathrm{dl}_{\text {track }}+\mathrm{dl}_{\text {ties }}+\mathrm{dl}_{\mathrm{gt}}=\quad 626.7 \mathrm{lb} / \mathrm{ft}
$$

RISA Automatically accounts for the self weight of the stringers and floor beams.

\section{Live Loads:}

Impact Load :

AREMA 1.3.5c (1)

Length $<80$ feet

$$
\begin{gathered}
I_{m}=40-\frac{3 * L^{2}}{1600}= \\
\therefore I_{m}=\quad 39.72 \%
\end{gathered}
$$

Impact Load Redutions:

AREMA Ch. 15 - 7.3.2.3 and Ch. 15 - 1.3.5(1)(a)

$$
\begin{aligned}
\mathrm{I}_{\text {red }} & =\max \left[1-\left(\frac{0.8}{2500}\right) *(60-S)^{2}, 0.2\right] \\
\mathrm{I} & =\mathrm{I}_{\mathrm{m}} * \mathrm{I}_{\text {red }}=\quad 7.94 \%
\end{aligned}
$$

Rocking Effect:

AREMA Ch. 15 - 1.3.5(d)

$$
\mathrm{RE}=\quad 20 \%
$$

\section{Centrifugal Force:}

AREMA Ch.15 - 1.3.6 


\section{Computation of Stresses:}

Live Load Shears and Moments are found using RISA software.

Live Load Moment:

$$
\begin{aligned}
& \mathrm{M}_{\mathrm{LL}}=\quad 128.80 \text { ft-kips } \\
& \mathrm{M}_{\mathrm{LL} \_80}=\quad M_{L L}\left(1+\frac{I}{100}+\frac{R E}{100}+\frac{C F_{V}}{100}\right)=\quad 128.8\left(1+\frac{7.94}{100}+\frac{20}{100}+\frac{0}{100}\right)=\quad 164.8 \quad \mathrm{ft}-\mathrm{kips} \\
& \text { Rating Factor }=\mathrm{RF}_{\mathrm{n}} \operatorname{Or~RF}_{\mathrm{m}}=\frac{\text { AllowableStress }\left(F_{b n}, F_{v n} \text { or } F_{b m}, F_{v m}\right)-\text { DeadLoad Stress }\left(F_{D L}\right)}{\operatorname{Live~Load~} \operatorname{Stress}\left(f_{L L}, f_{V L}\right)}
\end{aligned}
$$

Moment Ratings :

\begin{tabular}{|l|c|c|c|}
\hline Moment & Unfactored (Kip-ft) & Factored (Kip-ft) & Stress (ksi) \\
\hline Dead Load & 5.44 & N/A & 0.057 \\
\hline Live Load & 128.80 & 164.8 & 17.256 \\
\hline
\end{tabular}

\begin{tabular}{|l|c|c|}
\hline Moment Rating & Normal & Maximum \\
\hline Rating Factor & 0.95 & 1.39 \\
\hline Cooper E Rating & 76.2 & 111.0 \\
\hline
\end{tabular}

\section{Shear Ratings:}

Shear values per stringer:

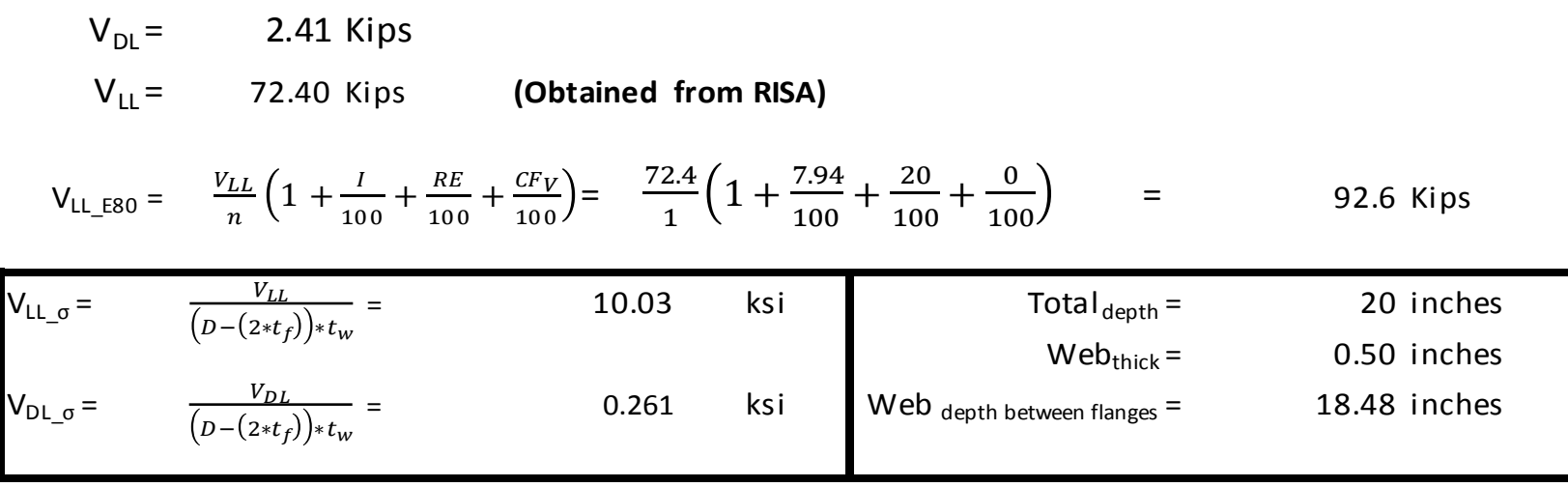

RATING:

\section{Normal}

$$
\mathrm{RF}_{\mathrm{Vn}}=\frac{\mathrm{F}_{\mathrm{Vn}-\mathrm{V}_{\mathrm{DL}_{\sigma} \sigma}}}{\mathrm{V}_{\mathrm{LL}_{-} \sigma}}=\frac{10.5-0 . .3}{9.84} * 80=\quad 81.7 \quad \text { or } \mathrm{E} 81.7
$$

$$
\mathrm{RF}_{\mathrm{Vm}}=\quad \frac{\mathrm{F}_{\mathrm{Vm}}-\mathrm{V}_{\mathrm{DL} \sigma}}{\mathrm{V}_{\mathrm{LL} \_} \sigma} * 80=\frac{18-0.3}{9.84} * 80=
$$

\section{Maximum}

141.5 or $\mathrm{E} 141.5$




\section{Eqvuivalent Cooper E Ratings (Moment):}

Live Load Moments And Shears are Obtained from RISA Software.

$$
\mathrm{M}_{\mathrm{LL} \_ \text {Factored }}=\quad M_{L L}\left(1+\frac{I}{100}+\frac{R E}{100}+\frac{C F_{V}}{100}\right) \quad \mathrm{V}_{\mathrm{LL}_{-} \text {Factored }}=\frac{V_{L L}}{n}\left(1+\frac{I}{100}+\frac{R E}{100}+\frac{C F_{V}}{100}\right)
$$

Equipment Load $=\quad \frac{\text { Equipment }(286 \text { Kips }, \text { GP 38, GP 9, WM 82) Live Load Moment or Shear }}{E 80 \text { Live Load Moment or Shear }} * 80$

\begin{tabular}{|c|c|c|c|c|}
\cline { 2 - 5 } \multicolumn{1}{c|}{} & 1 & 2 & 3 & 4 \\
\hline Live Load & 286 Kips & GP 38 & GP 9 & WM 82 \\
\hline Moment (Unfactored) (Kip-ft) & 98.04 & 76.56 & 79.50 & 72.50 \\
\hline Moment (factored) (Kip-ft) & 125.44 & 97.95 & 101.72 & 92.76 \\
\hline Equivalent Cooper Load & 60.90 & 47.55 & 49.38 & 45.03 \\
\hline Equivalent < Normal ? & OK & OK & OK & OK \\
\hline
\end{tabular}

\begin{tabular}{|c|c|c|c|c|}
\hline Live Load & 286 Kips & GP 38 & GP 9 & WM 82 \\
\hline Shear (Unfactored) (Kip-ft) & 55.70 & 38.30 & 39.70 & 36.30 \\
\hline Shear (factored) (Kip-ft) & 71.26 & 49.00 & 50.79 & 46.44 \\
\hline Equivalent Cooper Load & 61.55 & 42.32 & 43.87 & 40.11 \\
\hline Equivalent < Normal ? & OK & OK & OK & OK \\
\hline
\end{tabular}


APPENDIX - D 


\section{LOAD RATING ANALYSIS - GIRDER (Bridge 5.8)}

\section{BRIDGE DB 5.8}

\begin{tabular}{|c|c|c|c|}
\hline Steel density: & $\gamma_{S}=$ & $490 \mathrm{lb} / \mathrm{ft}^{3}$ & \\
\hline Span Length: & $\mathrm{L}=$ & $17.875 \mathrm{ft}$ & \\
\hline Number of Girders: & $\mathrm{n}=$ & 1 & \\
\hline Degree of Curve: & $D=$ & 1 degree & \\
\hline for 1 stringer & $\mathrm{I}_{\mathrm{xx}}=$ & $4662.779 \mathrm{in}^{4}$ & \\
\hline \multirow[t]{2}{*}{ Section Modulus: } & $\mathrm{S}_{\mathrm{x}}=$ & $306 \mathrm{in}^{3}$ & \\
\hline & $\mathrm{W}_{\text {Flange }}=$ & 12.63 in & \\
\hline C/S Area, Girder: & $A_{x}=$ & $30.01 \mathrm{in}^{2}$ & \\
\hline Radius of Gyration: & $r_{Y}=$ & $2.30 \mathrm{in}$ & \\
\hline Modulus of Elasticity & & 29000000 psi & \\
\hline $\mathrm{F}_{\mathrm{Y}}$ & & 30000 psi & AREMA 7.3.3.3 \\
\hline Unbraced Length = & $\mathrm{I}=$ & $10 \mathrm{ft}$ & \\
\hline
\end{tabular}

Allowable Stresses:

\section{Bending Moment:}

\begin{tabular}{|c|c|c|c|c|}
\hline \multirow[b]{2}{*}{ Tension: } & \multicolumn{4}{|c|}{ Normal } \\
\hline & \multirow[t]{2}{*}{$\mathrm{F}_{\mathrm{bpn}}:-$} & \multirow[t]{2}{*}{$0.55 * F_{Y}=$} & 16500 & psi \\
\hline & & & 16.5 & ksi \\
\hline
\end{tabular}

AREMA 7.3.4.3 and Table 15-1-11 and 15-7-1

Maximum
$\mathrm{F}_{\mathrm{bpm}}:-\quad 0.8^{*} \mathrm{~F}_{\mathrm{Y}}=$\begin{tabular}{r|r|}
24000 & $\mathrm{psi}$ \\
\hline 24 & $\mathrm{ksi}$
\end{tabular}

\section{Compression :}

Normal

$$
F_{b p n}-\frac{0.55 *\left(F_{Y}\right)^{2}}{6.3 * \pi^{2} * E} * \frac{I^{2}}{\left(r_{Y}\right)^{2}}=16500-\frac{0.55 *(30000)^{2}}{6.3 * \pi^{2} * 29 * 10^{6}} * \frac{(10 * 12)^{2}}{(2.09)^{2}} \mathrm{psi}=
$$

\begin{tabular}{|r|l|}
\hline 15752 & psi \\
\hline 15.752 & $\mathrm{ksi}$ \\
\hline
\end{tabular}

Maximum

$$
F_{b p m}-\frac{0.8 * F_{Y}}{1.8 * 10^{9}} * \frac{I^{2}}{\left(r_{Y}\right)^{2}}=24000-\frac{0.8 * 30000}{1.8 * 10^{9}} * \frac{(10 * 12)^{2}}{(2.09)^{2}} \text { psi }=
$$

22911 psi $22.911 \mathrm{ksi}$

\section{Allowable stresses for Rating :}

$$
\begin{array}{ll}
F_{b n}:- & \min \left(F_{b p n}, F_{b n n}\right)= \\
F_{b m}:- & \min \left(F_{b p m}, F_{b n m}\right)=
\end{array}
$$

\begin{tabular}{|l|l|l|l|}
\hline 15752 & psi & $>15.75$ & $\mathrm{ksi}$ \\
\hline 22911 & psi & $>22.91$ & $\mathrm{ksi}$ \\
\hline
\end{tabular}


Shear:

$$
\mathrm{F}_{\mathrm{vn}}:-0.35^{*} \mathrm{~F}_{\mathrm{Y}}=\begin{array}{|r|l|}
\hline 10500 & \mathrm{psi} \\
\hline 10.5 & \mathrm{ksi} \\
\hline
\end{array}
$$$$
F_{\mathrm{vm}}:-0.6 * F_{Y}=
$$

\begin{tabular}{|r|l|}
\hline 18000 & $\mathrm{psi}$ \\
\hline 18 & $\mathrm{ksi}$ \\
\hline
\end{tabular}

$\mathbf{F}_{\text {bpn }}$ :- Bending stress in tension, normal

$\mathbf{F}_{\text {bpm: }}$ :- Bending stress, tension, maximum

$\mathbf{F}_{\text {bnm1 }}, \mathbf{F}_{\text {bnma }}$ Bending stresses in extreme fibres in compression, Maximum

$\mathbf{F}_{\text {bnn1 }}, \mathbf{F}_{\text {bnn2 }}$ Bending stresses in extreme fibres in compression, Normal

$\mathbf{F}_{\text {bnn:- }}$ Bending stress in compression, normal

$\mathbf{F}_{\text {bnm }}$ :- Bending stress in compression, maximum

$\mathbf{F}_{\mathrm{Vm}}$ :- Shear stress, maximum

$\mathbf{F}_{\mathrm{Vn}}$ :- Shear stress, normal

\section{Dead Loads:}

Tie Size and Spacing

$\begin{array}{rccc}\text { Tie width: } & \mathrm{W}_{\mathrm{t}}= & 8 & \text { in } \\ \text { Tie Height: } & \mathrm{h}_{\mathrm{t}}= & 16 & \text { in } \\ \text { Tie Spacing: } & \mathrm{S}_{\mathrm{t}}= & 12 & \text { in } \\ \text { Tie Length: } & \mathrm{L}_{\mathrm{t}}= & 10 & \mathrm{ft} \\ \text { Tie Density: } & \mathrm{r}_{\mathrm{t}}= & 60 & \mathrm{lb} / \mathrm{ft}^{3}\end{array}$

$$
\begin{aligned}
& \text { Track rails, inside guide rail \& fastening: } \quad \mathrm{dl}_{\text {track }}=\quad 200 \mathrm{lb} / \mathrm{ft} \\
& \text { Ties: } \quad \mathrm{dl}_{\text {ties }}=\frac{W_{t^{*}} h_{t^{*} L_{t} *} \gamma_{t}}{S_{t}}=533.3 \mathrm{lb} / \mathrm{ft} \\
& \text { Guard Timber: } \quad \mathrm{dl}_{\mathrm{gt}}=\left(2 * 4 * 8 * \gamma_{t}\right)=26.66667 \mathrm{lb} / \mathrm{ft} \\
& \text { Track system Dead Load : } \quad \mathrm{W}_{\mathrm{DL}}=\mathrm{dl}_{\text {track }}+\mathrm{dl}_{\text {ties }}+\mathrm{dl}_{\mathrm{gt}}=760.0 \mathrm{Ib} / \mathrm{ft}
\end{aligned}
$$

RISA Automatically accounts for the self weight of the stringers and floor beams. 
*All the measurements are checked by WVU-CFC during an inspection in May-201،

WEB:

\begin{tabular}{rllll|} 
Web $_{\text {depth }}=$ & $W_{d}=$ & 30.5 & inches & \\
Web $_{\text {thickness }}=$ & $W_{t}=$ & 0.375 & inches & Angle 1
\end{tabular}

ANGLE:

\begin{tabular}{|c|c|c|}
\hline $\operatorname{Leg}_{\text {vertical }}=$ & $\mathrm{V}_{\text {leg }}=$ & 4.25 \\
\hline Leg $_{\text {horizontal }}=$ & $\mathrm{H}_{\text {leg }}=$ & 6.13 \\
\hline $\operatorname{Leg}_{\text {thickness }}=$ & $\mathrm{T}_{\text {leg }}=$ & 0.47 \\
\hline
\end{tabular}

Area of cross section:

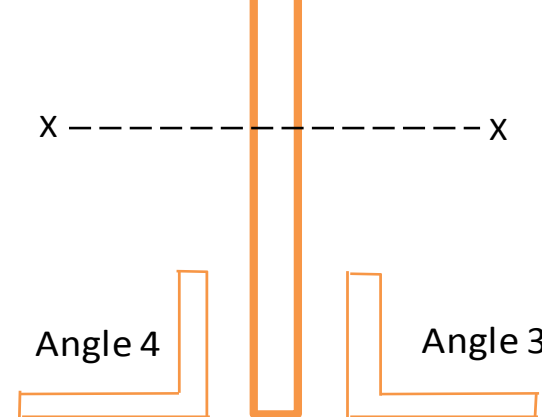

$$
\begin{aligned}
& \left.A_{x}=(30.5 * 0.375)+(4 *[(6.125 * 0.46875)+(4.25-0.46875) * 0.46875)]\right) \\
& A_{x}=30.01 \mathrm{in}^{2}
\end{aligned}
$$

Moment of inertia:

\begin{tabular}{|c|c|c|c|c|c|c|c|}
\hline \multicolumn{8}{|c|}{ Strong Axis Moment Of Inertia } \\
\hline Component & Base & Depth & Area & $Y$ & $A Y^{2}$ & $\mathrm{I}_{\mathrm{O}}$ & $I_{x x}$ \\
\hline Web & 0.375 & 30.5 & 11.44 & 0 & 0 & 886.6445 & 886.6445 \\
\hline Hor. leg - Angle 1 & 6.13 & 0.47 & 2.87 & 15.02 & 647.3426 & 0.052571 & 647.3952 \\
\hline Ver. Leg - Angle 1 & 0.47 & 3.78 & 1.77 & 12.89 & 294.5267 & 2.111865 & 296.6385 \\
\hline Hor. leg - Angle 2 & 6.13 & 0.47 & 2.87 & 15.02 & 647.3426 & 0.052571 & 647.3952 \\
\hline Ver. Leg - Angle 2 & 0.47 & 3.78 & 1.77 & 12.89 & 294.5267 & 2.111865 & 296.6385 \\
\hline Hor. leg - Angle 3 & 6.13 & 0.47 & 2.87 & -15.02 & 647.3426 & 0.052571 & 647.3952 \\
\hline Ver. Leg - Angle 3 & 0.47 & 3.78 & 1.77 & -12.89 & 294.5267 & 2.111865 & 296.6385 \\
\hline Hor. leg - Angle 4 & 6.13 & 0.47 & 2.87 & -15.02 & 647.3426 & 0.052571 & 647.3952 \\
\hline Ver. Leg - Angle 4 & 0.47 & 3.78 & 1.77 & -12.89 & 294.5267 & 2.111865 & 296.6385 \\
\hline & & & 30.01 & & & & 4662.78 \\
\hline
\end{tabular}

$$
\begin{array}{r}
\mathrm{I}_{\mathrm{xx}}=\left(\frac{0.375 * 30.5^{3}}{12}\right)+4^{*}\left[\left(\frac{6.125 * 0.46875^{3}}{12}\right)+\left((6.125 * 0.46875) *\left(\frac{30.5}{2}-\frac{0.46875}{2}\right)^{2}\right)\right]+ \\
4 *\left[\left(\frac{0.46875 * 3.78125^{3}}{12}\right)+\left((3.78125 * 0.46875) *\left(\frac{30.5}{2}-\left(0.46875+\frac{3.78125}{2}\right)^{2}\right)\right]\right. \\
\mathrm{I}_{\mathrm{xx}}=4662.78 \mathrm{in}^{4}
\end{array}
$$




\begin{tabular}{|l|c|c|c|c|c|c|c|}
\hline \multicolumn{1}{|l|}{ Weak Axis Moment Of Inertia } & \multicolumn{1}{l|}{} \\
\hline Component & Base & Depth & Area & $\mathbf{Y}$ & A $^{\mathbf{2}}$ & $\mathbf{I}_{\mathbf{O}}$ & $\mathrm{I}_{\mathbf{X x}}$ \\
\hline Web & 30.5 & 0.375 & 11.44 & 0 & 0 & 0.134033 & 0.134033 \\
\hline Hor. leg - Angle 1 & 0.47 & 6.13 & 2.87 & 3.25 & 30.32593 & 8.975906 & 39.30183 \\
\hline Ver. Leg - Angle 1 & 3.78 & 0.47 & 1.77 & 0.42 & 0.31546 & 0.032455 & 0.347915 \\
\hline Hor. leg - Angle 2 & 0.47 & 6.13 & 2.87 & 3.25 & 30.32593 & 8.975906 & 39.30183 \\
\hline Ver. Leg - Angle 2 & 3.78 & 0.47 & 1.77 & 0.42 & 0.31546 & 0.032455 & 0.347915 \\
\hline Hor. leg - Angle 3 & 0.47 & 6.13 & 2.87 & -3.25 & 30.32593 & 8.975906 & 39.30183 \\
\hline Ver. Leg - Angle 3 & 3.78 & 0.47 & 1.77 & -0.42 & 0.31546 & 0.032455 & 0.347915 \\
\hline Hor. leg - Angle 4 & 0.47 & 6.13 & 2.87 & -3.25 & 30.32593 & 8.975906 & 39.30183 \\
\hline Ver. Leg - Angle 4 & 3.78 & 0.47 & 1.77 & -0.42 & 0.31546 & 0.032455 & 0.347915 \\
\hline
\end{tabular}

\section{\begin{tabular}{l|l} 
Total & 30.01 \\
\hline
\end{tabular}}

158.73

$$
\begin{aligned}
\mathrm{I}_{\mathrm{yy}}= & \left(\frac{30.5 * 0.375^{3}}{12}\right)+4 *\left(\left(\frac{6.125^{3} * 0.46875}{12}\right)+\left((6.125 * 0.46875) *\left(\frac{0.375}{2}+\frac{6.125}{2}\right)^{2}\right)\right) \\
& +4 *\left(\left(\frac{0.46875^{3} * 3.78}{12}\right)+\left((3.78 * 0.4375) *\left(\frac{0.375}{2}+\frac{0.4375}{2}\right)^{2}\right)\right)=158.73 \mathrm{in}^{4}
\end{aligned}
$$

\begin{tabular}{|c|l|}
\hline Section Modulus: & Radius of Gyration : \\
$\mathrm{S}_{\mathrm{x}}=\quad \frac{I_{x x}}{\left(w_{d}\right)}$ & $\mathrm{r}_{\mathrm{y}}=\sqrt{\frac{I_{y y}}{A}}=\sqrt{\frac{131.11}{30.11}}=2.30$ inches \\
$\mathrm{S}_{\mathrm{x}}=\quad 306 \mathrm{in}^{3}$ & \\
&
\end{tabular}


Live Loads:

Moments Ratings:

$\underline{\text { Impact }}$

AREMA 1.3.5c (1)

Length $<80$ feet

$$
I_{m}=40-\frac{3 * L^{2}}{1600}=\quad 39.40091
$$

$\therefore \mathrm{I}_{\mathrm{m}}=39.40091 \%$

Impact Load Redutions:

AREMA Ch. 15 - 7.3.2.3 and Ch. 15 - 1.3.5(1)(a)

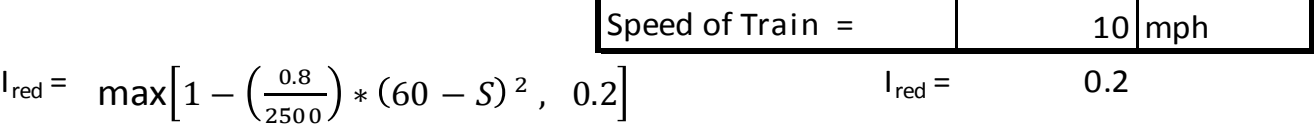

$$
\begin{aligned}
& \begin{array}{l|l|l|l}
\mathrm{I}= & \mathrm{I}_{\mathrm{m}} * \mathrm{I}_{\text {red }}= & 7.880 & \% \\
\hline
\end{array}
\end{aligned}
$$

Rocking Effect:

RE $=\quad 20 \mid \%$

AREMA Ch. 15 - 1.3.5(d)

\section{Centrifugal Force:}

AREMA Ch.15 - 1.3.6

$$
\mathrm{C}=\quad\left(0.00117 * S^{2} * D\right)=\quad 0.263 \%
$$

$$
\mathrm{CF}_{\mathrm{V}}=\text { Centrifugal Force }=\quad C * \frac{8 \mathrm{ft}}{56.5 \mathrm{in}}=\frac{0.45}{\mathrm{~m}} \mathrm{\%}
$$




\section{Computation of Stresses:}

Live Load Shears and Moments are found using RISA software.

Live Load Moment:

$$
\begin{aligned}
& \mathrm{M}_{\mathrm{LL}}=\quad 335.00 \text { ft-kips } \\
& \mathrm{M}_{\mathrm{LL}_{-} \mathrm{E} 80}=\quad M_{L L}\left(1+\frac{I}{100}+\frac{R E}{100}+\frac{C F_{V}}{100}\right)=\quad 335\left(1+\frac{7.885}{100}+\frac{20}{100}+\frac{0.45}{100}\right)=\quad 429.9 \quad \mathrm{ft}-\mathrm{kips} \\
& \text { Rating Factor }=\operatorname{RF}_{\mathrm{n}} \operatorname{Or~RF}_{\mathrm{m}}=\frac{\text { AllowableStress }\left(F_{b n}, F_{v n} \text { or } F_{b m}, F_{v m}\right)-\text { Dead Load Stress }\left(F_{D L}\right)}{\text { Live Load Stress }\left(f_{L L}, f_{V L}\right)} * 80
\end{aligned}
$$

Moment Ratings :

\begin{tabular}{|c|c|c|c|}
\hline Moment & Unfactored (Kip-ft) & Factored (Kip-ft) & Stress (ksi) \\
\hline Dead Load & 19.268 & N/A & 0.756 \\
\hline Live Load & 335.00 & 429.9 & 16.872 \\
\hline
\end{tabular}

\begin{tabular}{|l|c|c|}
\hline Moment Rating & Normal & Maximum \\
\hline Rating Factor & 0.89 & 1.31 \\
\hline Cooper E Rating & 71.1 & 105.0 \\
\hline
\end{tabular}

\section{Shear Ratings:}

Shear values per stringer:

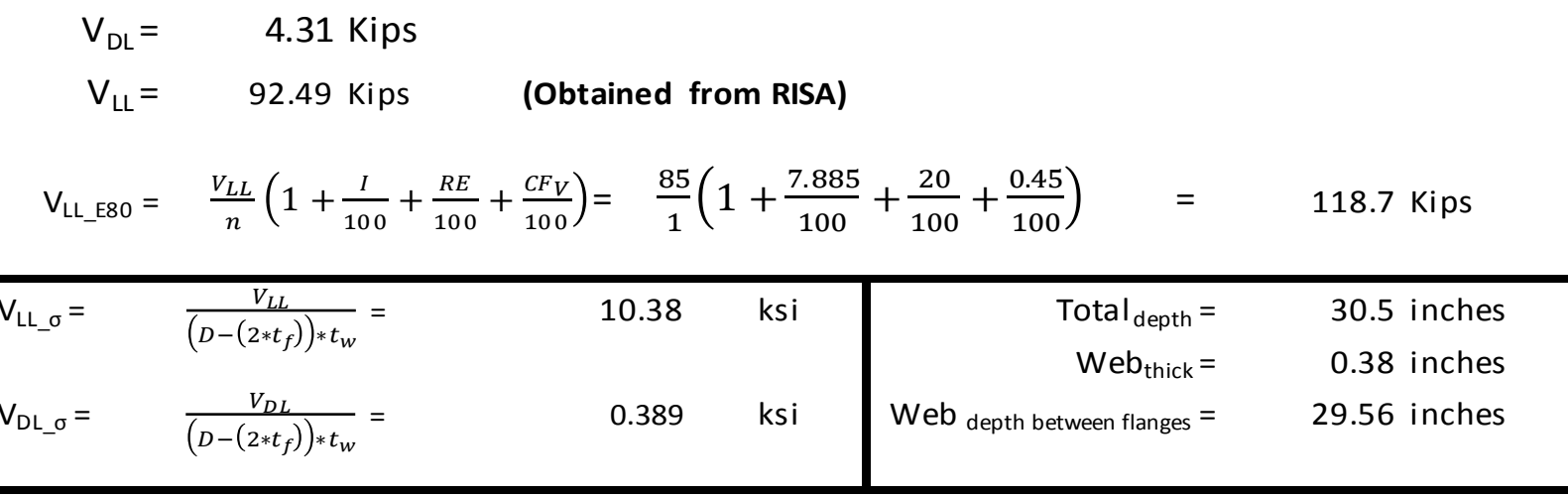

RATING:

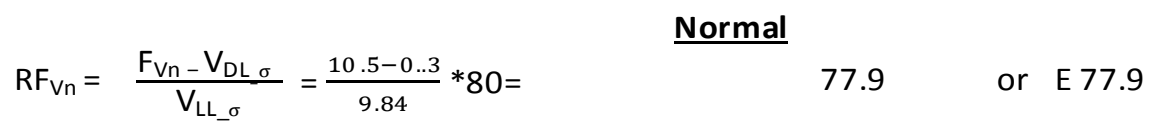

\section{Maximum}

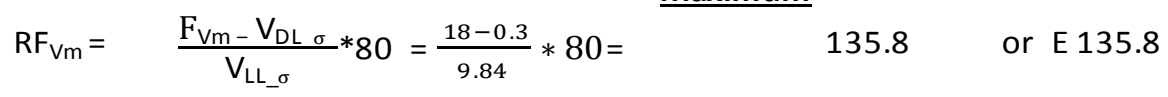




\section{Eqvuivalent Cooper E Ratings (Moment):}

Live Load Moments And Shears are Obtained from RISA Software.

$$
\mathrm{M}_{\mathrm{LL}_{-} \text {Factored }}=\quad M_{L L}\left(1+\frac{I}{100}+\frac{R E}{100}+\frac{C F_{V}}{100}\right) \quad \mathrm{V}_{\mathrm{LL}_{-} \text {Factored }}=\frac{V_{L L}}{n}\left(1+\frac{I}{100}+\frac{R E}{100}+\frac{C F_{V}}{100}\right)
$$

Equivalent Coper E-load $=\frac{\text { Equipment (286 Kips, GP 38, GP 9, WM 82) Live Load Moment or Shear }}{E 80 \text { Live Load Moment or Shear }} * 80$

\begin{tabular}{|c|c|c|c|c|}
\cline { 2 - 5 } \multicolumn{1}{c|}{} & 1 & 2 & 3 & 4 \\
\hline Live Load & 286 Kips & GP 38 & GP 9 & WM 82 \\
\hline Moment (Unfactored) (Kip-ft) & 254.60 & 138.67 & 140.89 & 128.69 \\
\hline Moment (factored) (Kip-ft) & 326.72 & 177.95 & 180.80 & 165.14 \\
\hline Equivalent Cooper Load & 60.80 & 33.12 & 33.65 & 30.73 \\
\hline Equivalent < Normal ? & OK & OK & OK & OK \\
\hline
\end{tabular}

\begin{tabular}{|c|c|c|c|c|}
\hline Live Load & 286 Kips & GP 38 & GP 9 & WM 82 \\
\hline Shear (Unfactored) (Kip-ft) & 70.25 & 46.50 & 47.16 & 42.75 \\
\hline Shear (factored) (Kip-ft) & 90.15 & 59.68 & 60.52 & 54.86 \\
\hline Equivalent Cooper Load & 60.76 & 40.22 & 40.79 & 36.98 \\
\hline Equivalent < Normal ? & OK & OK & OK & OK \\
\hline
\end{tabular}


APPENDIX - E 


\section{STRAIN CALULATIONS (Hi-Rail Dump Truck and WM 82).}

\section{Theoretical Strain WM82 - Plate Girder - Span 1 and Span 2}

Max. Live Load Moment obtained from RISA software.

$\mathrm{M}_{\mathrm{LL}-\text { Span } 1}=\quad 1806.5 \mathrm{ft}$-kips

$\mathrm{M}_{\mathrm{LL}-\text { Span 2 }}=1767.91 \mathrm{ft}-\mathrm{kips}$

Bending stresses per stringer:

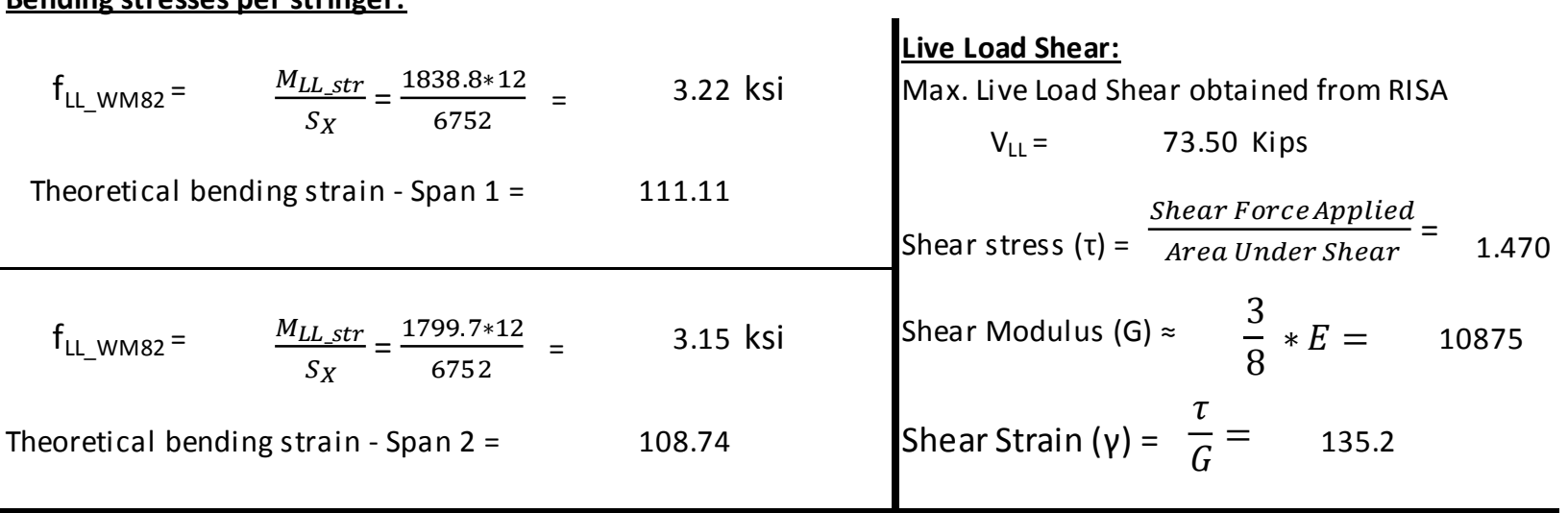

\section{Theoretical Bending Strain Dump Truck - Plate Girder-Span 1 and Span 2}

Max. Live Load Moment obtained from RISA software.

$$
\begin{array}{ll}
\mathrm{M}_{\mathrm{LL}-\text { Span 1 }}= & 681.6 \mathrm{ft}-\mathrm{kips} \\
\mathrm{M}_{\mathrm{LL}-\text { Span 2 }}= & 670.4 \mathrm{ft}-\mathrm{kips}
\end{array}
$$

\section{Stress per stringer:}

$\mathrm{f}_{\mathrm{LL}_{-} \text {Dump Truck }}=\quad \frac{M_{L L \_s t r}}{S_{X}}=\frac{681.6 * 12}{6752}=1.22 \mathrm{ksi}$

Theoretical bending strain - Span $1=$

$\mathrm{f}_{\mathrm{LL} \_ \text {Dump Truck }}=\quad \frac{M_{L L \_s t r}}{S_{X}}=\frac{670.4 * 12}{6752}=$

Theoretical bending strain - Span $1=$
41.92

$1.20 \mathrm{ksi}$

41.23
Live Load Shear:

Max. Live Load Shear obtained from RISA

$$
\mathrm{V}_{\mathrm{LL}}=\quad 26 \mathrm{Kips}
$$

Shear Stress $(\tau)=\frac{\text { Shear Force Applied }}{\text { Area Under Shear }}=0.520$

Shear Modulus $(\mathrm{G}) \approx \frac{3}{8} * E=10875$

Shear Strain $(\gamma)=\frac{\tau}{G}=\quad 47.8$

\begin{tabular}{|c|c|c|c|c|}
\hline \multicolumn{5}{|c|}{ Bridge 1.4 Analytical Strains } \\
\hline Vehicle & Member & Span & Bending Strain & Shear Strain \\
\hline Dump Truck & Plate Girder & 1 & 41.92 & 47.8 \\
\hline Train & Plate Girder & 1 & 111.11 & 135.2 \\
\hline Dump Truck & Plate Girder & 2 & 41.23 & \\
\hline Train & Plate Girder & 2 & 108.74 & \\
\hline
\end{tabular}




\section{Theoretical Strain WM82 - Floor Beam}

Max. Live Load Moment obtained from RISA software.

$$
\mathrm{M}_{\mathrm{LL}}=\quad 125.8 \mathrm{ft} \text {-kips }
$$

Bending moments and stresses per stringer:

$$
\begin{aligned}
& \text { Live Load Shear: } \\
& \text { Max. Live Load Shear obtained from RISA } \\
& V_{L L}=34.99 \text { Kips } \\
& \mathrm{f}_{\mathrm{LL} \_\mathrm{WM} 82}=\frac{M_{L L_{-} s t r}}{S_{X}}=\frac{125.8 * 12}{341}=4.42 \mathrm{ksi} \\
& \text { Theoritical bending strain }=\quad 152.50 \\
& \text { Shear stress }(\tau)=\frac{\text { Shear Force Applied }}{\text { Area Under Shear }}=2.212 \\
& \begin{array}{l}
\text { Shear Modulus }(G) \approx \frac{3}{8} * E= \\
\text { Shear Strain }(\gamma)=\frac{\tau}{G}=203.39
\end{array}
\end{aligned}
$$

\section{Theoretical Bending Strain Dump Truck - Floor Beam}

Max. Live Load Moment obtained from RISA software.

$$
\mathrm{M}_{\mathrm{LL}}=\quad 63.9 \mathrm{ft} \text {-kips }
$$

Stress per stringer:

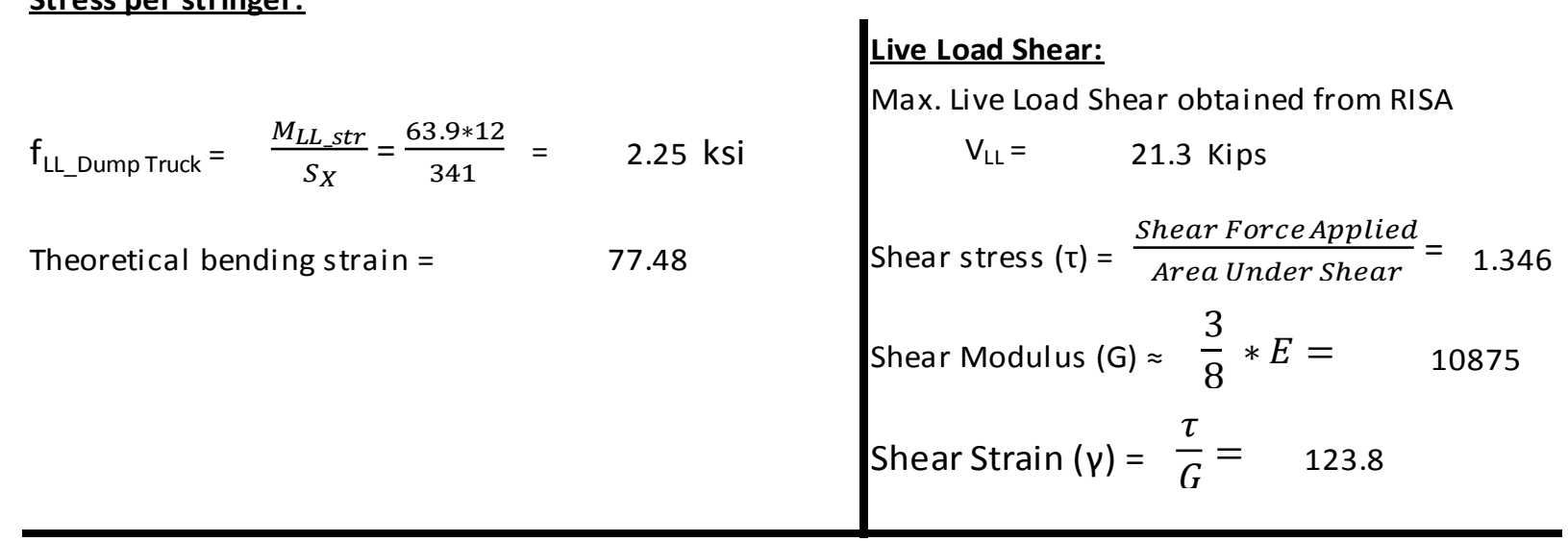

Bridge 1.4 Analytical Strains

\begin{tabular}{|c|c|c|c|}
\hline Vehicle & Member & Bending Strain & Shear Strain \\
\hline Dump Truck & Plate Girder & 77.48 & 123.8 \\
\hline Train & Plate Girder & 152.50 & 203.4 \\
\hline
\end{tabular}


The strain gage used for finding bending strain was not placed at the longitudinal center, instead it was placed towards the end of the stringer, due to reachability problems. Hence, to find the strain at that location, the moment has to be found at that location. This can be done by Interpolation.

Theoretical Strain WM82 - Stringer

Live Load Moment obtained from RISA software.

$$
\mathrm{M}_{\mathrm{LL}}=\quad 23.2 \mathrm{ft} \text {-kips } \quad \text { (After interpolation) }
$$

Bending moments and stresses per stringer:

$\mathrm{f}_{\mathrm{LL} \_\mathrm{WM} 82}=\frac{M_{L L \_s t r}}{S_{X}}=\frac{23.2 * 12}{114.6}=$

$2.43 \mathrm{ksi}$

Theoretical bending strain $=$

83.81

\begin{tabular}{|c|c|c|}
\hline \multicolumn{3}{|c|}{ Member $\mathbf{5 6}(\mathbf{9 . 6 3} \mathbf{f t})$ (Moment-Interpolation) } \\
\hline Unit & Length-ft & Moment k-ft \\
\hline 0 & 0 & 0 \\
\hline 1 & 0.9625 & -13.133 \\
\hline 2 & 1.925 & 23.12 \\
\hline 3 & 2.8875 & -39.886 \\
\hline 4 & 3.85 & -44.3245 \\
\hline 5 & 4.8125 & -48.763 \\
\hline 6 & 5.775 & -45.6745 \\
\hline 7 & 6.7375 & -42.586 \\
\hline 8 & 7.7 & 24.512 \\
\hline 9 & 8.6625 & -9.048 \\
\hline 10 & 9.625 & 0 \\
\hline
\end{tabular}

\section{$\underline{\text { Theoretical Bending Strain Dump Truck - Stringer }}$}

Live Load Moment obtained from RISA software.

$$
\mathrm{M}_{\mathrm{LL}}=21.453 \mathrm{ft}-\mathrm{kips}
$$

\section{Stress per stringer:}

$\mathrm{f}_{\mathrm{LL} \_ \text {Dump Truck }}=\frac{M_{\text {LL_str }}}{S_{X}}=\frac{21.453 * 12}{114.6}=2.25 \mathrm{ksi}$

Theoretical bending strain $=\quad 77.46$ 
APPENDIX - F 
INSPECTION CHARTS - Bridge 1.4 and Bridge 5.8.

\begin{tabular}{|c|c|c|c|c|}
\hline \multicolumn{5}{|c|}{ BRIDGE NO. 1.4 INSPECTION REPORT FORM } \\
\hline \multicolumn{4}{|c|}{ WVU-CFC Inspection } & \multirow{3}{*}{$\begin{array}{l}\text { Recommended repairs by } \\
\text { WVU-CFC/Reason }\end{array}$} \\
\hline & AS INSPECTED & CLASS & 2014 Inspection & \\
\hline \multirow{5}{*}{$\begin{array}{l}\text { 昰 } \\
\text { 岕 }\end{array}$} & Drainage Opening & & opening is in good condition. & \\
\hline & $\begin{array}{l}\text { Channel Scouring, } \\
\text { silting, etc. }\end{array}$ & & $\begin{array}{l}\text { Silt not visible at bottom, the } \\
\text { water is deep. }\end{array}$ & \\
\hline & Slopes, Rip Rap & C 3 & $\begin{array}{l}\text { Loss of Ballast, as the slopes } \\
\text { being steep, as said in previous } \\
\text { reports, build timber walls to } \\
\text { maintain ballast level. }\end{array}$ & $\begin{array}{l}\text { Building timber walls, using } \\
\text { gabions might maintain the } \\
\text { ballast level }\end{array}$ \\
\hline & $\begin{array}{c}\text { General } \\
\text { Cleanliness }\end{array}$ & C 3 & $\begin{array}{c}\text { Vegetation and debris at both } \\
\text { the ends, maintenance is } \\
\text { required. }\end{array}$ & \\
\hline & Paint type & & $\begin{array}{l}\text { Paint failures, with peeling and } \\
\text { poor conditions }\end{array}$ & $\begin{array}{c}\text { rust, re-paint the surface to } \\
\text { protect the members from } \\
\text { rusting. }\end{array}$ \\
\hline & & & & \\
\hline \multirow{6}{*}{ 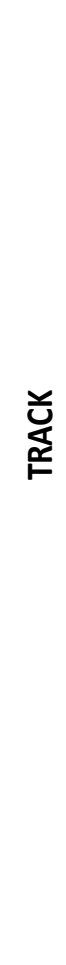 } & $\begin{array}{l}\text { Approach } \\
\text {,Surface, } \\
\text { Alignment }\end{array}$ & & $\begin{array}{c}\text { Two to three damaged ties at } \\
\text { north approach, both approaches } \\
\text { are low, leaving a quarter to half } \\
\text { inch gap under the rails at both } \\
\text { approaches. }\end{array}$ & $\begin{array}{c}\text { Replace the ties, add clean } \\
\text { ballast build timber walls to } \\
\text { maintain ballast level }\end{array}$ \\
\hline & Deck & C 3 & $\begin{array}{c}\text { open deck, wooden walkway on } \\
\text { the bridge has to be replaced, its } \\
\text { in poor condition. }\end{array}$ & \\
\hline & $\begin{array}{l}\text { Bridge Surface } \\
\text { alignment }\end{array}$ & & Good Condition & \\
\hline & Ballast & & ballast is low at both approaches. & $\begin{array}{l}\text { Add Ballast and build timber } \\
\text { walls. }\end{array}$ \\
\hline & Ties, tie spacers & C 3 & $\begin{array}{l}\text { Span } 1-87 \text { ties, span } 2-84 \text { ties, } \\
\text { replace } 1 \text { tie in span } 1 \text {, 3ties in } \\
\text { span } 2 . \text { Rotted tie spacers near } \\
\text { pier } 1 \text {, and both abutments, } \\
\text { replace them. }\end{array}$ & \\
\hline & Rail & & joint rail has some cracks & \\
\hline
\end{tabular}




\begin{tabular}{|c|c|c|c|c|}
\hline \multirow{4}{*}{ 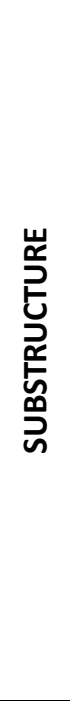 } & $\begin{array}{c}\text { Abutment, Bridge } \\
\text { Seat }\end{array}$ & & $\begin{array}{l}\text { Both concrete abutments exhibit } \\
\text { map cracking, minor scaling, } \\
\text { beam seats have hairline cracks }\end{array}$ & \\
\hline & Back wall & & $\begin{array}{c}\text { Concrete back walls exhibits map } \\
\text { cracking }\end{array}$ & \\
\hline & Wing wall & & $\begin{array}{l}\text { Wing walls Exhibit minor map } \\
\text { cracking, minor delamination's }\end{array}$ & \\
\hline & Pier & & $\begin{array}{l}\text { The pier has some minor cracks } \\
\text { on the side surfaces and rust } \\
\text { stains on top surface of pier }\end{array}$ & $\begin{array}{c}\text { Patching the cracks should } \\
\text { solve the problem. Deep } \\
\text { water level was the reason } \\
\text { for not inspecting the bottom } \\
\text { of pier. }\end{array}$ \\
\hline \multirow{4}{*}{ 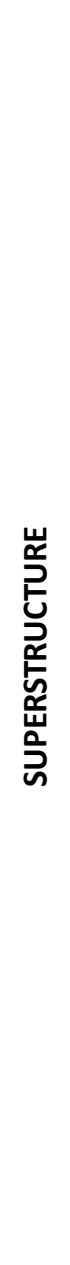 } & Span Type & & Simple span through plate girder & \\
\hline & Steel Girders & $\mathrm{C} 4$ & $\begin{array}{l}\text { The interior bottom flange angles } \\
\text { on the NW end of Girder } 2 \\
\text { exhibits severe corrosion. With } \\
\text { loss on the horizontal and } \\
\text { vertical leg of flanges expected } \\
\text { to be } 0.25 " . \text { NE end of the Girder } \\
1 \text { has a laterally bent bottom } \\
\text { flange (exterior side). }\end{array}$ & $\begin{array}{l}\text { Loss of section due to } \\
\text { corrosion, the debris should } \\
\text { be cleaned by jetting water } \\
\text { on to the corroded parts as it } \\
\text { was hard to remove the rust } \\
\text { by hand. The bottom flange } \\
\text { angles are components of } \\
\text { fracture critical member } \\
\text { hence care should be taken if } \\
\text { repair is the primary } \\
\text { recommendation or else it } \\
\text { might lead to bridge collapse. } \\
\text { Looking at the angles the loss } \\
\text { is expected to be } 0.25 ", \text { the } \\
\text { original will be known after } \\
\text { cleaning the debris. }\end{array}$ \\
\hline & Floor Beams & & $\begin{array}{l}\text { Flanges exhibit corrosion and } \\
\text { pitting up to }(1 / 8)^{\prime \prime}\end{array}$ & \\
\hline & $\begin{array}{l}\text { Sole Plates, } \\
\text { Anchor Bolts }\end{array}$ & C 3 & $\begin{array}{l}\text { Anchor Bolts have section loss at } \\
\text { the bottom say } 1.5^{\prime *} 1.5^{\prime \prime} . \\
\text { Expansion bearings are pushed } \\
\text { against anchor bolts. Reset } \\
\text { expansion bearings. }\end{array}$ & $\begin{array}{c}\text { Replace the anchor bolts and } \\
\text { expansion bearings have to } \\
\text { be reset. }\end{array}$ \\
\hline
\end{tabular}




\begin{tabular}{|c|c|c|c|}
\hline \multirow{4}{*}{ 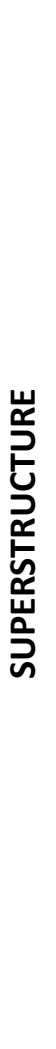 } & Cover Plates & $\begin{array}{l}\text { Minor surface rusting on cover } \\
\text { plates }\end{array}$ & $\begin{array}{c}\text { Clean the surface with water } \\
\text { jets and paint the member } \\
\text { to prevent from further } \\
\text { rusting. }\end{array}$ \\
\hline & $\begin{array}{c}\text { Cross Frames/ } \\
\text { Diaphragms }\end{array}$ & minor rusting & \\
\hline & Lateral Bracing & $\begin{array}{l}\text { Gusset Plate near the North end } \\
\text { have holes up to } 1 / 2 \text { inch } \\
\text { diameter and rusting. }\end{array}$ & $\begin{array}{l}\text { Replace the gusset plate. } \\
\text { The gusset plate not being a } \\
\text { fractural critical component, } \\
\text { it can be replacement is not } \\
\text { a problem }\end{array}$ \\
\hline & Stiffeners & $\begin{array}{c}\text { Some of the Interior stiffeners } \\
\text { exhibit corrosion and } 100 \% \\
\text { section loss, deterioration is } \\
\text { worst near abutments }\end{array}$ & $\begin{array}{l}\text { Replace the stiffeners. } \\
\text { Looking at the location of } \\
\text { the stiffeners, it implicates } \\
\text { the stiffeners are not } \\
\text { fractural critical component } \\
\text { of the through girder hence } \\
\text { it is not that hard to replace } \\
\text { the stiffeners even with } \\
100 \% \text { section loss }\end{array}$ \\
\hline
\end{tabular}

\begin{tabular}{|c|c|}
\hline Class & Grading Criteria \\
\hline C 1 & $\begin{array}{r}\text { Prompt attention needed. Notify owner immediately. Condition should be repaired within } \\
30 \text { days. If less than 30 days, give the timetable }\end{array}$ \\
\hline C 2 & $\begin{array}{r}\text { Recommend repair within 9 months. If not repaired, it is possible that condition could } \\
\text { develop that results in bridge closure prior to next year's annual inspection }\end{array}$ \\
\hline C 3 & Recommend repair within 3 years \\
\hline C 4 & Monitor the condition at each annual inspection \\
\hline
\end{tabular}




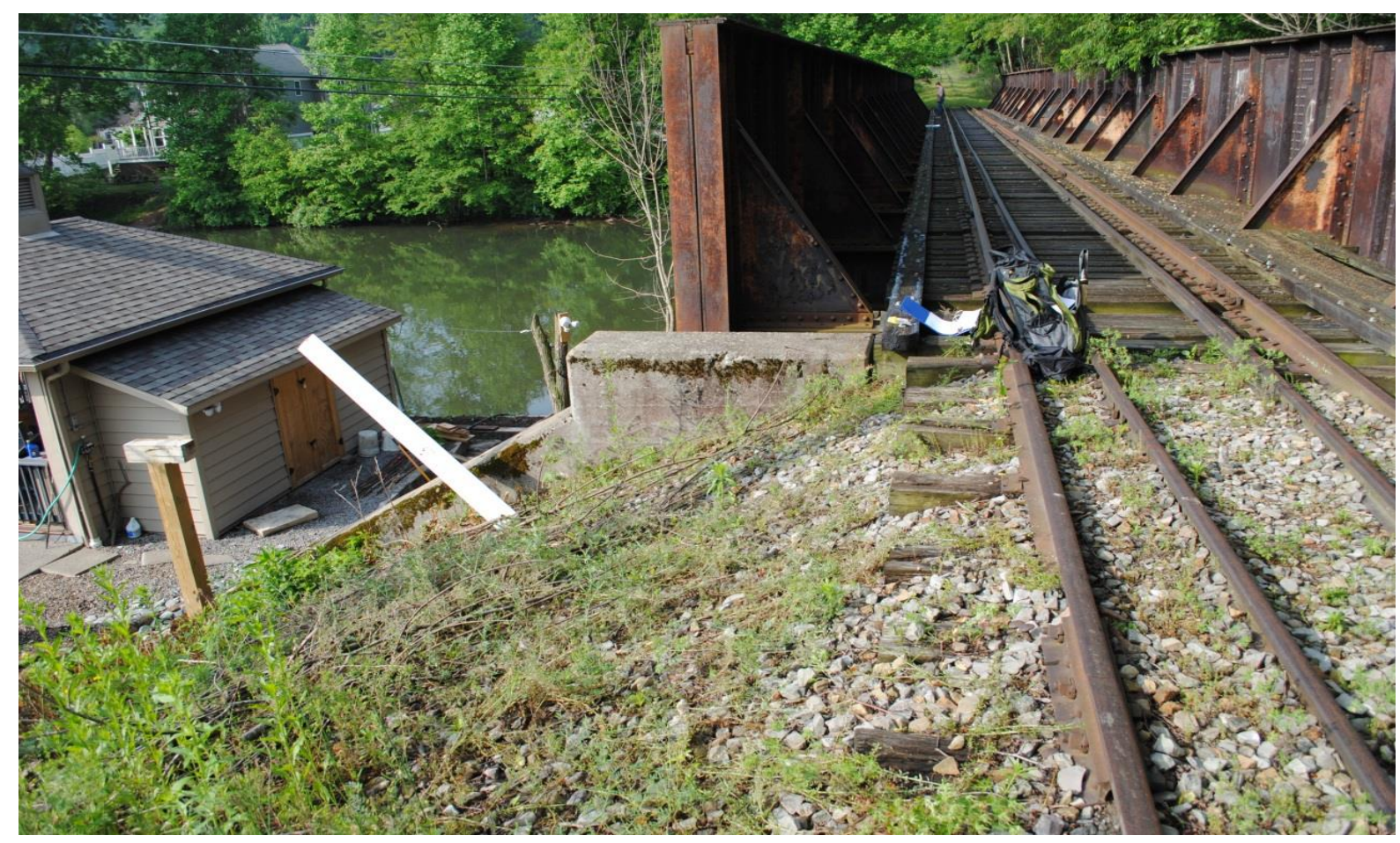

Figure F1. Loss of Ballast on slopes, Vegetation seen at bottom of Slopes as per WVU-CFC Inspection July-2014

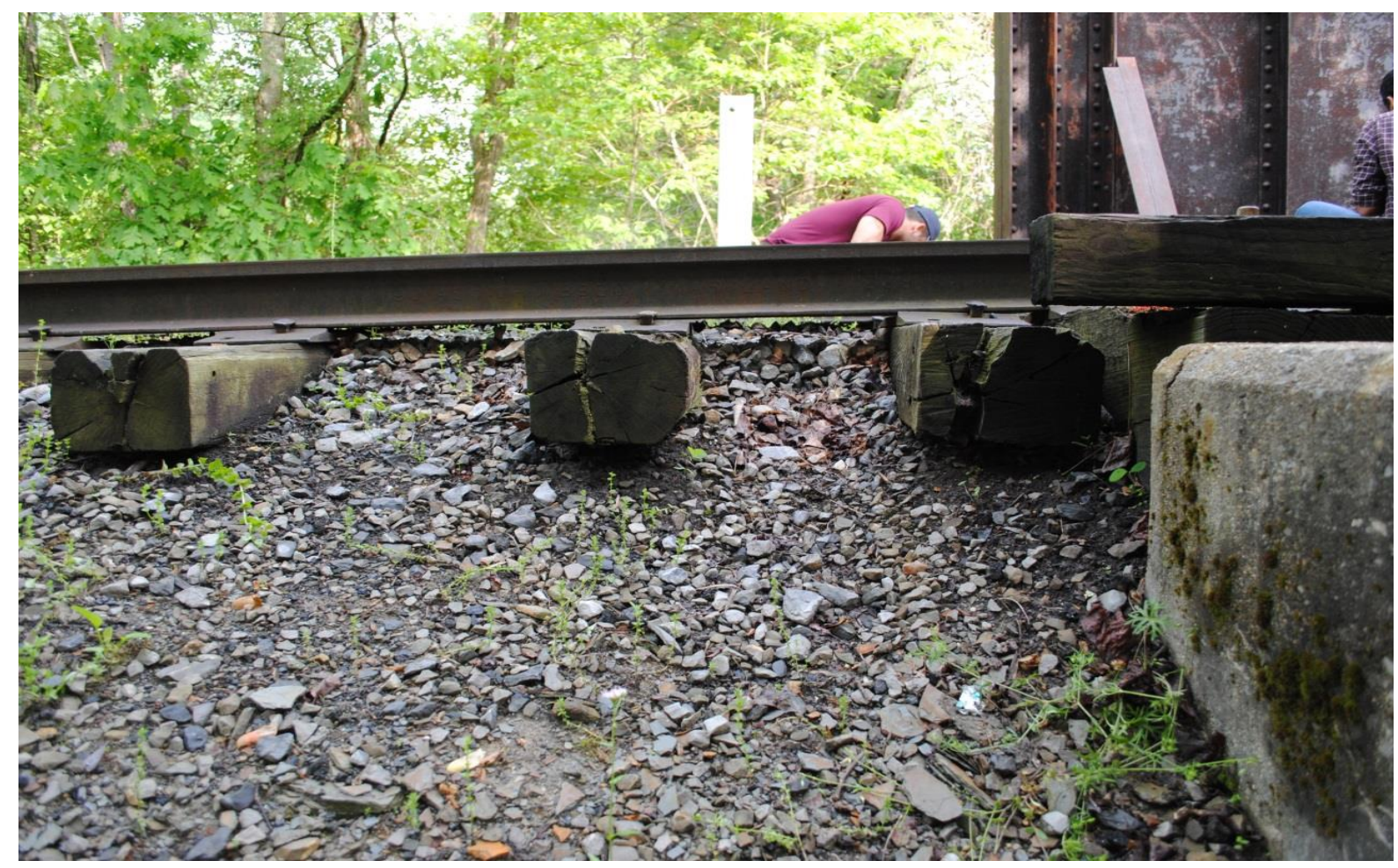

Figure F2 Low Approaches on North, Leaving Half Inch Gap. WVU-CFC Inspection, July-2014 


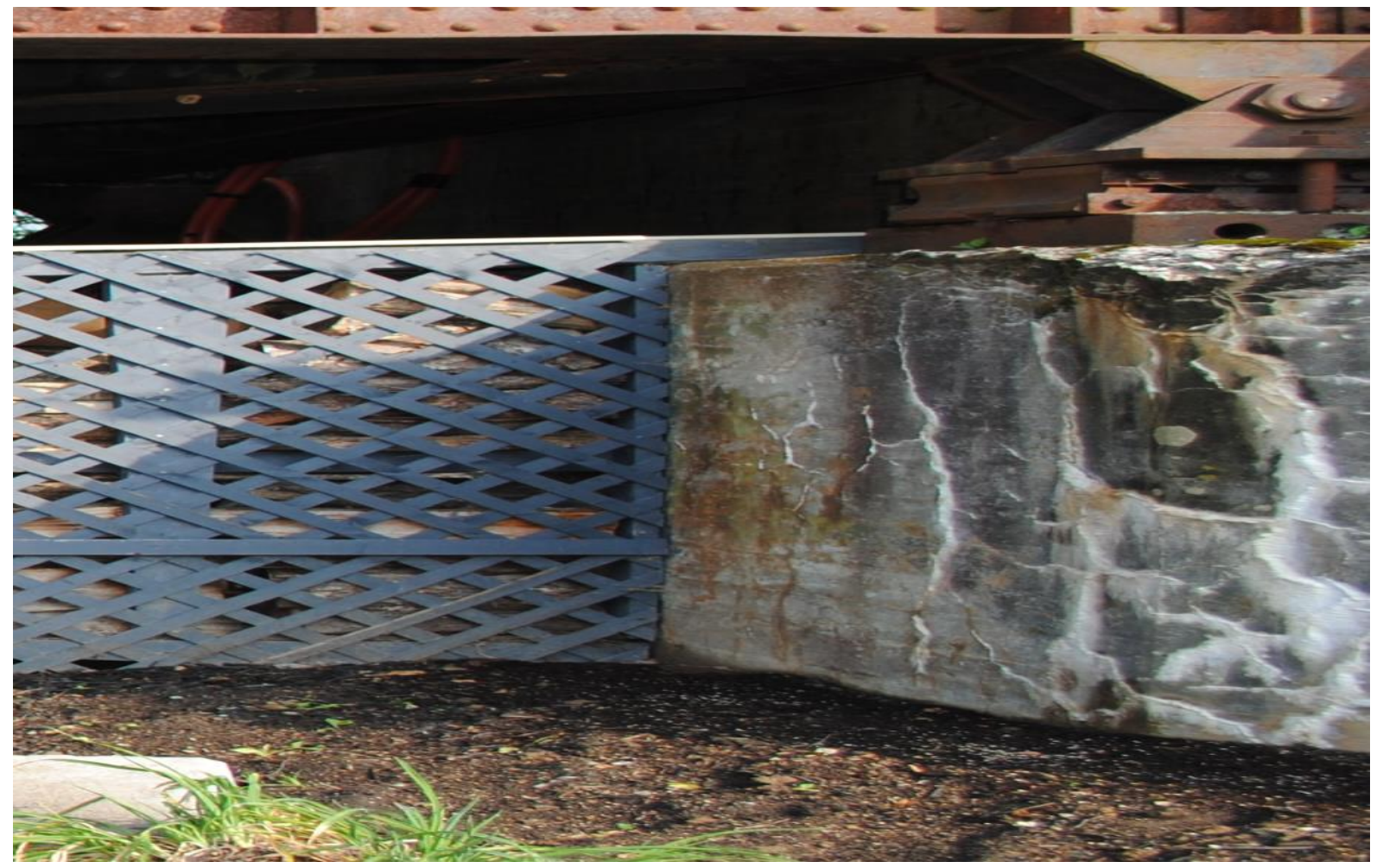

Figure F3. Map Cracking's on North Abutment and Beam Seat have Hairline Cracks, WVU-CFC Inspection July-2014

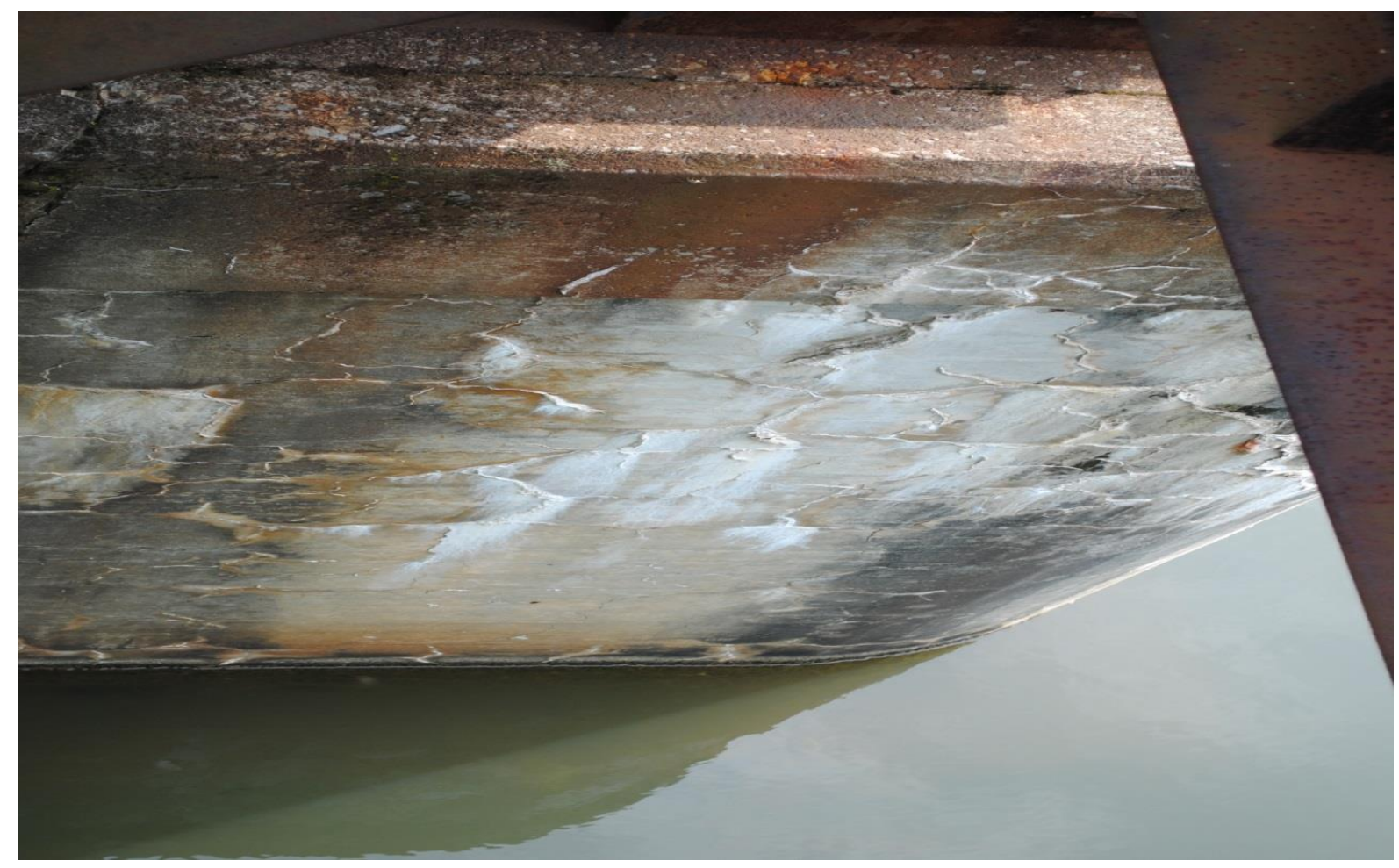

Figure F4. Pier has Minor Cracks on the Side Surfaces of the Pier and Rust Stains on the Top Surface, Silt Cannot be seen as the Water is too Deep. 


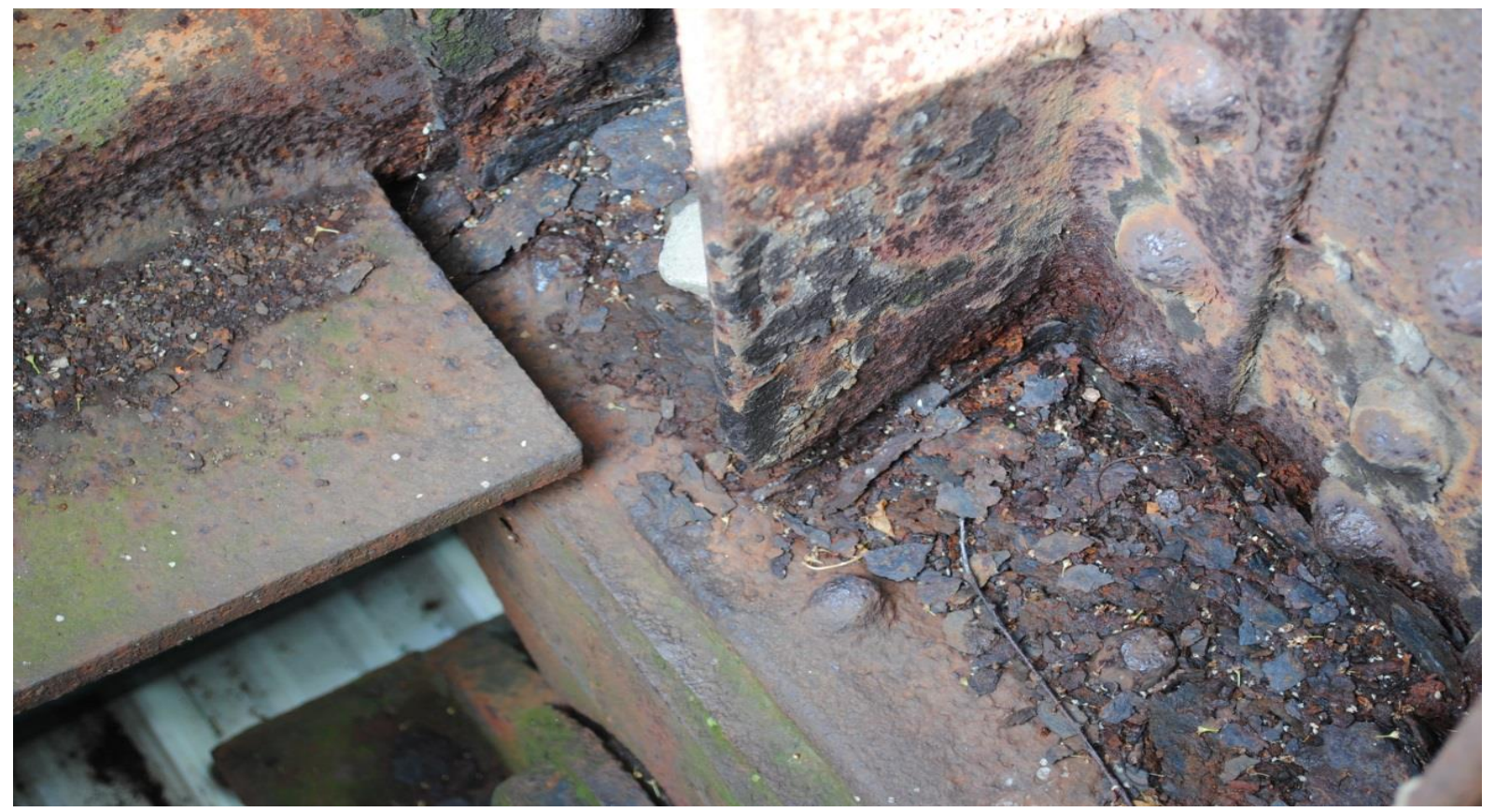

Figure F5. Severe corrosion on Girder 2 bottom interior flange, losses up to 1/4 inch

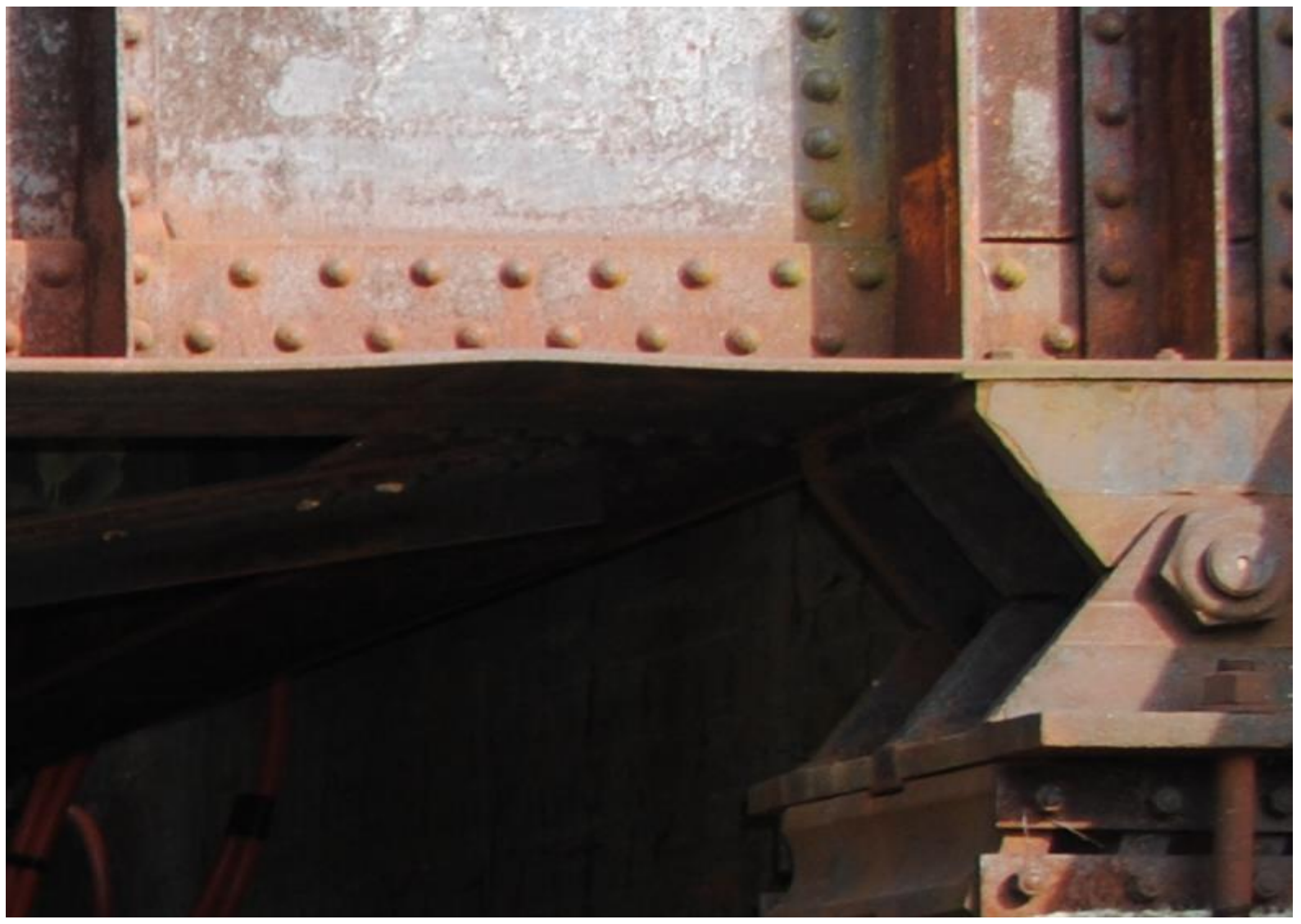

Figure F6. Bent bottom flange near the bearing on NE end of Girder 1 

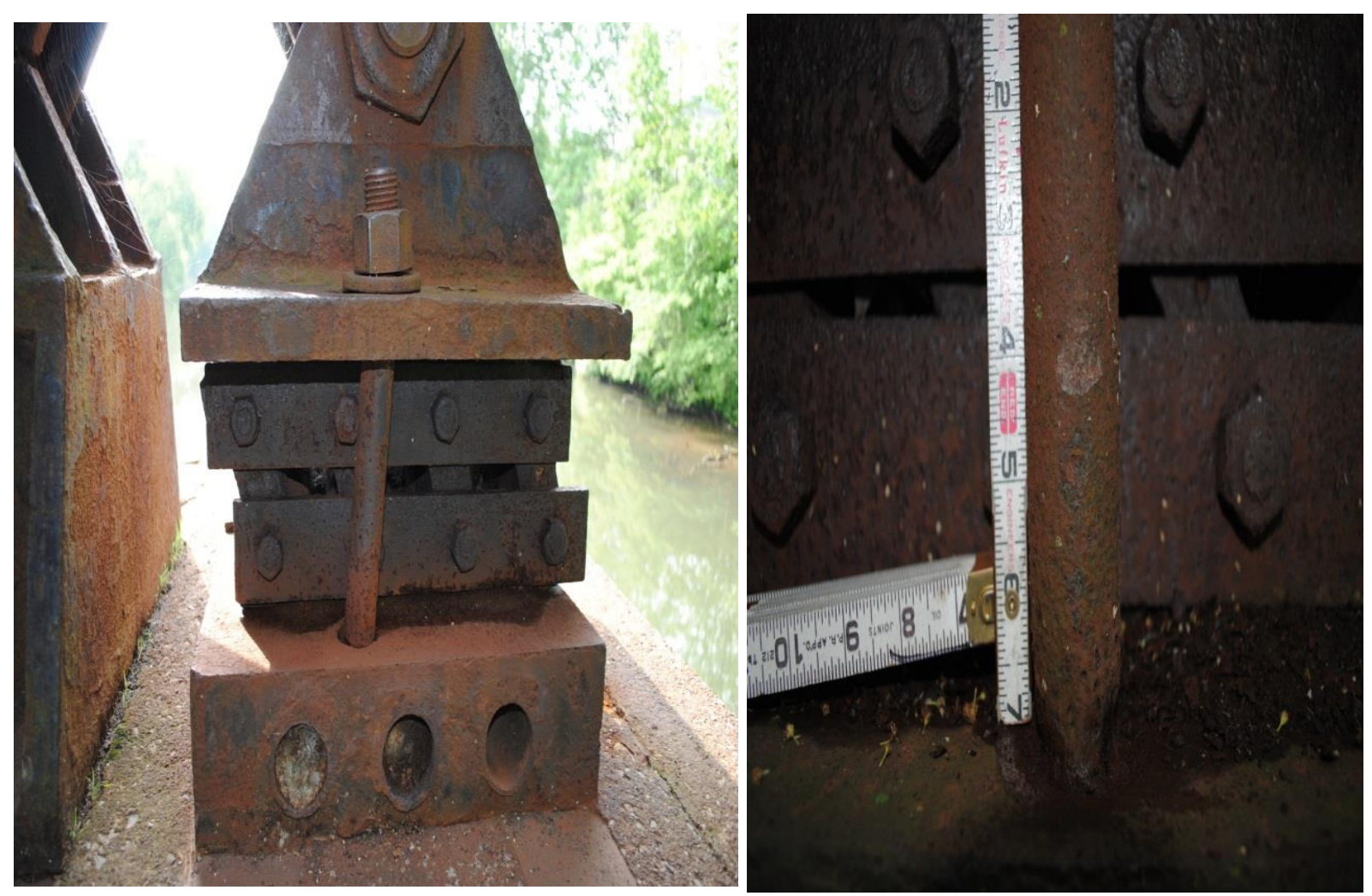

Figure F7 Expansion Bearings Pushed Against Anchor Bolts, Anchor Bolts having section Ioss of 1.5" * 1.5"

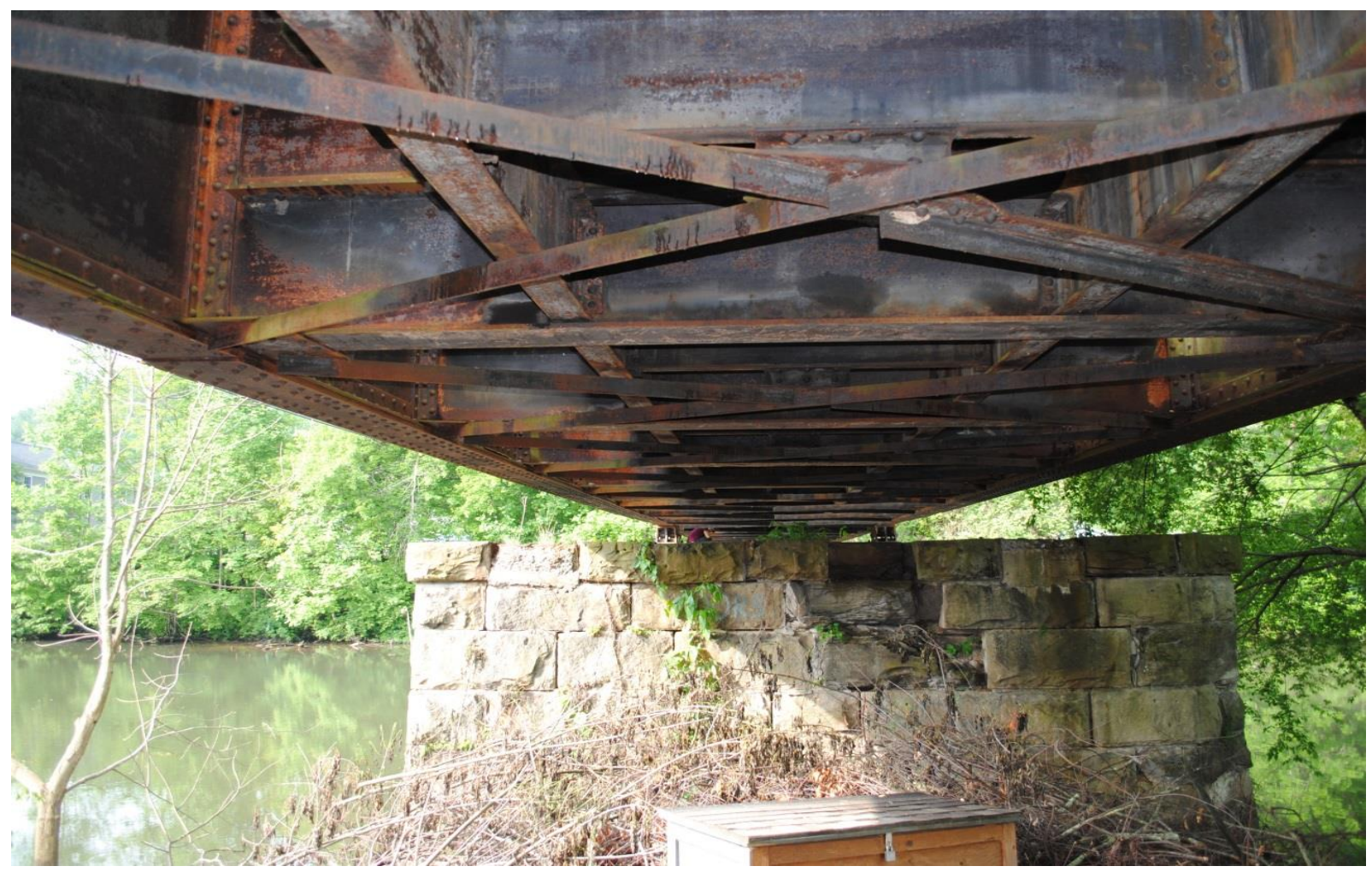

Figure F8. Cross Frames, Diaphragms exhibit minor rusting 


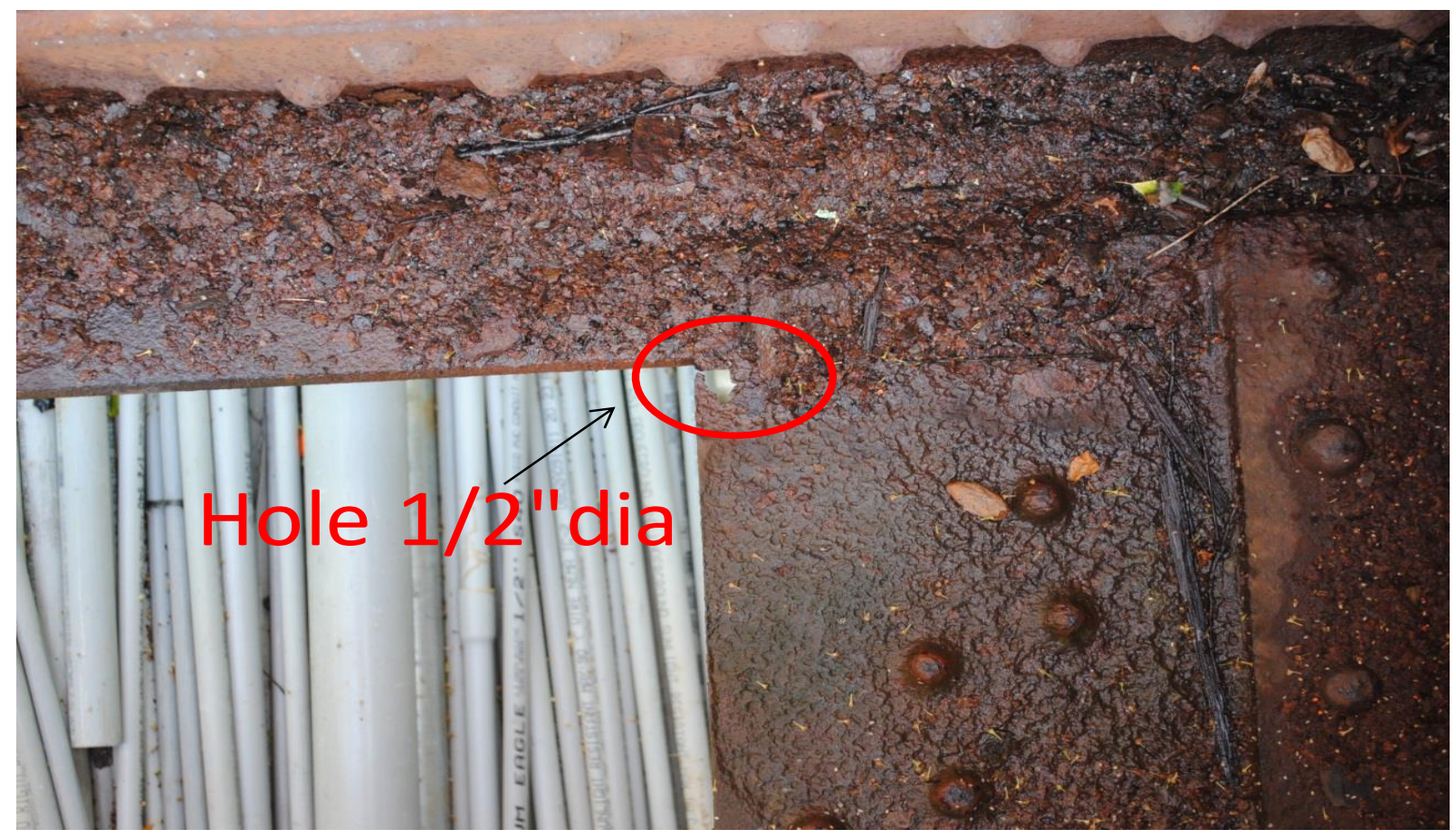

Figure F9. Gusset Plate near North abutment has a loss of section of $1 / 2$ inch dia., rusting

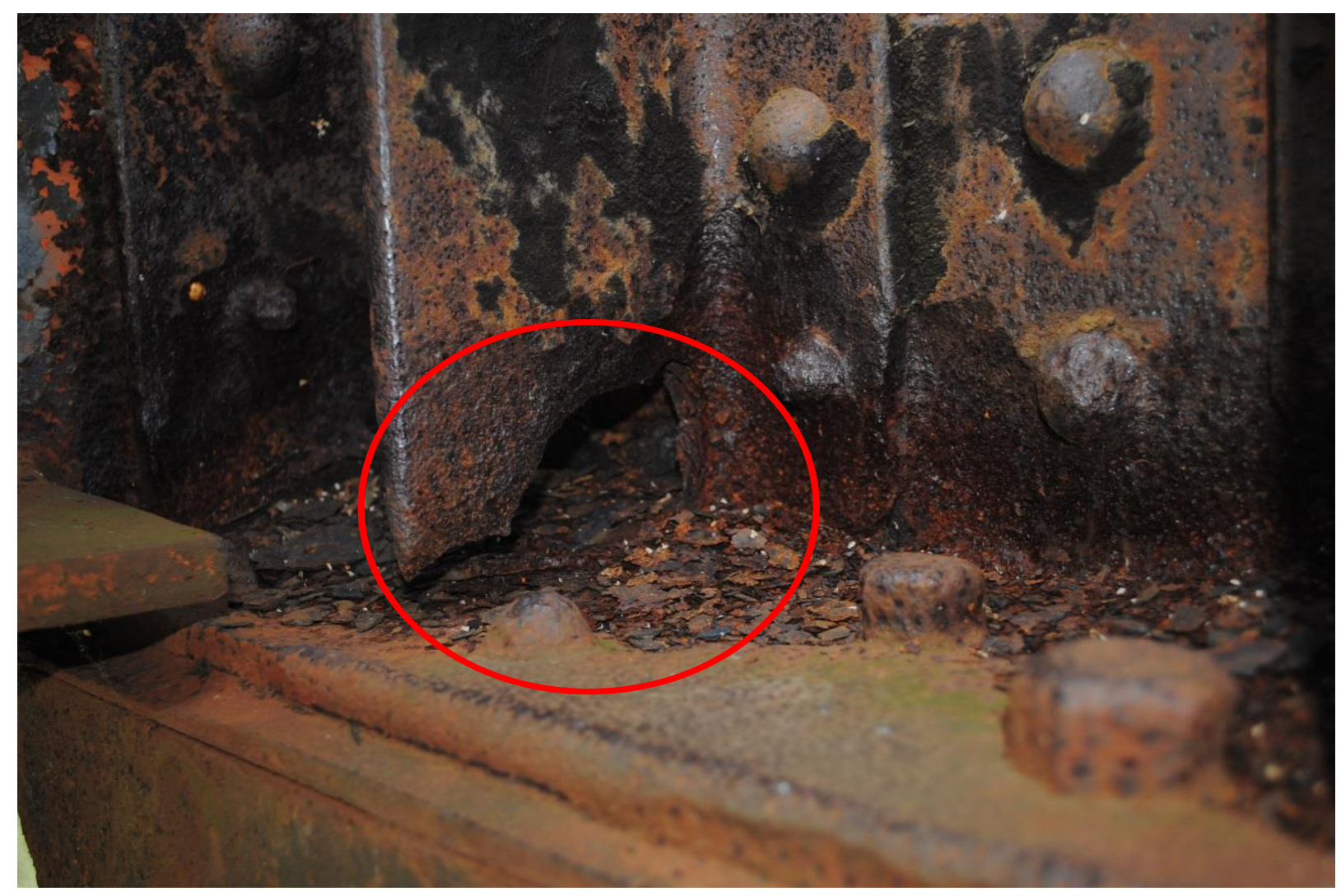

Figure F10. Interior Stiffeners has $100 \%$ section loss, most of the stiffeners exhibit corrosion. 


\begin{tabular}{|c|c|c|c|c|}
\hline \multicolumn{5}{|c|}{ BRIDGE NO. 5.8 INSPECTION REPORT FORM } \\
\hline \multicolumn{4}{|c|}{ WVU-CFC Inspection } & \multirow{3}{*}{$\begin{array}{l}\text { Recommended repairs by } \\
\text { WVU-CFC/Suggestions }\end{array}$} \\
\hline \multicolumn{2}{|c|}{ ITEMS INSPECTED } & CLASS & 2014 Inspection & \\
\hline \multirow{5}{*}{$\begin{array}{l}\text { 荵 } \\
\text { 岕 }\end{array}$} & Drainage Opening & & $\begin{array}{c}\text { Stream flows along the north } \\
\text { abutment }\end{array}$ & \\
\hline & $\begin{array}{c}\text { Channel Scouring, } \\
\text { silting, etc. }\end{array}$ & & No scour found & \\
\hline & Slopes, Rip Rap & C 4 & $\begin{array}{c}\text { The North end of the bridge } \\
\text { has a bank which is eroded to } \\
\text { a minor extent. Vegetation is } \\
\text { seen on slopes }\end{array}$ & $\begin{array}{l}\text { Bank erosion can be solved by } \\
\text { using plant material on the } \\
\text { bank and reinforcing the soil } \\
\text { or use of rock riprap or } \\
\text { gabions. As the problem of } \\
\text { bank erosion is not too } \\
\text { severe, yearly inspections } \\
\text { would be sufficient. }\end{array}$ \\
\hline & General Cleanliness & C 3 & $\begin{array}{l}\text { Ballast and debris on top } \\
\text { surface of abutments }\end{array}$ & $\begin{array}{l}\text { Cleaning of debris as well as } \\
\text { ballast on top of the } \\
\text { abutment is recommended as } \\
\text { water might stagnate for } \\
\text { longer time creating } \\
\text { dampness and water may go } \\
\text { through the spaces in the } \\
\text { stones leading mortar loss. } \\
\text { There were some debris on } \\
\text { the bottom flanges and cross } \\
\text { frames and in the longer run } \\
\text { rusting of members may be } \\
\text { seen. }\end{array}$ \\
\hline & Paint type & C 4 & $\begin{array}{l}\text { The paint is in good condition } \\
\text { for major portion of the } \\
\text { bridge except for some } \\
\text { locations }\end{array}$ & $\begin{array}{l}\text { The portions where the paint } \\
\text { is lost, rusting of section was } \\
\text { noticed. Re-painting the } \\
\text { bridge members can prevent } \\
\text { them from more rusting and } \\
\text { it also covers the patches } \\
\text { where there was paint loss. } \\
\text { Since the paint loss is not } \\
\text { severe and re-painting is an } \\
\text { not immediate need, yearly } \\
\text { inspection would be } \\
\text { sufficient. }\end{array}$ \\
\hline & & & & \\
\hline
\end{tabular}




\begin{tabular}{|c|c|c|c|c|}
\hline \multirow{6}{*}{$\begin{array}{l}\text { Ũ } \\
\stackrel{\leftarrow}{\mathbb{1}}\end{array}$} & Approach & C 3 & Slightly low at north approach & $\begin{array}{l}\text { If the approach is too low, the } \\
\text { tracks are raised by means of } \\
\text { jack and ballast is added to } \\
\text { maintain a straight surface. } \\
\text { Timber walls are built to } \\
\text { prevent ballast from sliding. } \\
\text { The approach being "slightly" } \\
\text { low, is not a severe problem. } \\
\text { Hence, inspecting every } 3 \\
\text { months is suggested instead } \\
\text { of repair. }\end{array}$ \\
\hline & Deck & & Open Deck & \\
\hline & $\begin{array}{c}\text { Bridge Surface } \\
\text { alignment }\end{array}$ & & OK & \\
\hline & Ballast & C 3 & $\begin{array}{l}\text { ballast is low at shoulders, at } \\
\text { least a quarter inch gap is } \\
\text { seen. Add clean ballast }\end{array}$ & $\begin{array}{l}\text { Addition of clean ballast and } \\
\text { use of timber walls or nets to } \\
\text { maintain ballast level is } \\
\text { recommended. }\end{array}$ \\
\hline & Ties, tie spacers & & good condition & \\
\hline & Rail & & $\begin{array}{c}\text { joint rail has some cracks and } \\
\text { chipping at } \mathrm{N} \text { end }\end{array}$ & Replace it with new joints \\
\hline \multicolumn{5}{|c|}{ ABUTMENTS ARE NUMBERED FROM NORTH TO SOUTH, WITH ABUTMENT 1 BEING AT THE NORTH END OF THE BRIDGE } \\
\hline \multirow[b]{2}{*}{ 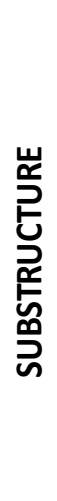 } & $\begin{array}{c}\text { Abutment, Bridge } \\
\text { Seat }\end{array}$ & C 4 & $\begin{array}{l}\text { The Masonry Abutment has } \\
\text { loss of mortar seen at the } \\
\text { joints, gap is seen between } \\
\text { stones. }\end{array}$ & $\begin{array}{l}\text { Grouting and surface finish } \\
\text { may help to fill the gaps and } \\
\text { make the abutment look neat }\end{array}$ \\
\hline & Wing wall & C 4 & $\begin{array}{l}\text { The wing walls are } \\
\text { continuation of abutments } \\
\text { which also has gaps between } \\
\text { stones, the cap stones are } \\
\text { offset } 2 \text { " from lower stones }\end{array}$ & $\begin{array}{l}\text { Align the stones of abutment } \\
\text { to be in a line and to fill the } \\
\text { gaps, epoxy grouting is } \\
\text { suggested. The gaps and } \\
\text { alignment are not a serious } \\
\text { threat to the bridge. }\end{array}$ \\
\hline \multirow{3}{*}{ 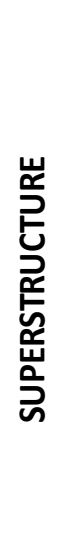 } & Span Type & & Simple span deck plate girder & \\
\hline & Steel Girders & & $\begin{array}{l}\text { Minor surface rust on bottom } \\
\text { flanges, the interior bottom } \\
\text { flange of Girder } 1 \text { is bent, may } \\
\text { be a manufacturing mistake }\end{array}$ & $\begin{array}{c}\text { Clean the surface rust and } \\
\text { painting is suggested. The } \\
\text { bent bottom flange might be } \\
\text { a maufacturing mistake. Does } \\
\text { not look a failure due to } \\
\text { loading. Replacement of that } \\
\text { angle is not required. }\end{array}$ \\
\hline & Floor Beams & & $\mathrm{N} / \mathrm{A}$ & $N / A$ \\
\hline
\end{tabular}




\begin{tabular}{|c|c|c|c|}
\hline \multirow{4}{*}{ 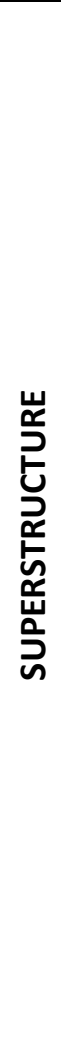 } & $\begin{array}{l}\text { Sole Plates, } \\
\text { Anchor Bolts }\end{array}$ & Minor corrosion & \\
\hline & $\begin{array}{l}\text { Cross Frames/ } \\
\text { Diaphragms }\end{array}$ & $\begin{array}{l}\text { Minor corrosion is seen on } \\
\text { end cross frames and bottom } \\
\text { rivets, SE and SW } \\
\text { connection. }\end{array}$ & $\begin{array}{l}\text { Use water jets to clean the } \\
\text { rust and paint the members. }\end{array}$ \\
\hline & Lateral Bracing & $\begin{array}{l}\text { Minor corrosion at gusset } \\
\text { connections }\end{array}$ & \\
\hline & Stiffeners & $\begin{array}{l}\text { The exterior stiffener near } \\
\text { NW end is bent may be a } \\
\text { manufacturing mistake and } \\
\text { interior stiffeners have minor } \\
\text { corrosion }\end{array}$ & $\begin{array}{l}\text { Clean the surface rust and } \\
\text { painting is suggested. The } \\
\text { stiffener which is bent should } \\
\text { be replaced. The place where } \\
\text { the stiffener is on the bridge, } \\
\text { while replacing it may not } \\
\text { cause any catastrophe. It is } \\
\text { not a severe threat having } \\
\text { the bent stiffener on the } \\
\text { bridge. Hence annual } \\
\text { inspection is suggested as } \\
\text { replacement is not primary } \\
\text { suggestion. }\end{array}$ \\
\hline
\end{tabular}

\begin{tabular}{|c|c|}
\hline Class & Grading Criteria \\
\hline C 1 & $\begin{array}{r}\text { Prompt attention needed. Notify owner immediately. Condition should be repaired within 30 } \\
\text { days. If less than 30 days, give the timetable }\end{array}$ \\
\hline C 2 & $\begin{array}{r}\text { Recommend repair within 9 months. If not repaired, it is possible that condition could } \\
\text { develop that results in bridge closure prior to next year's annual inspection }\end{array}$ \\
\hline C 3 & Recommend repair within 3 years \\
\hline C 4 & Monitor the condition at each annual inspection \\
\hline
\end{tabular}




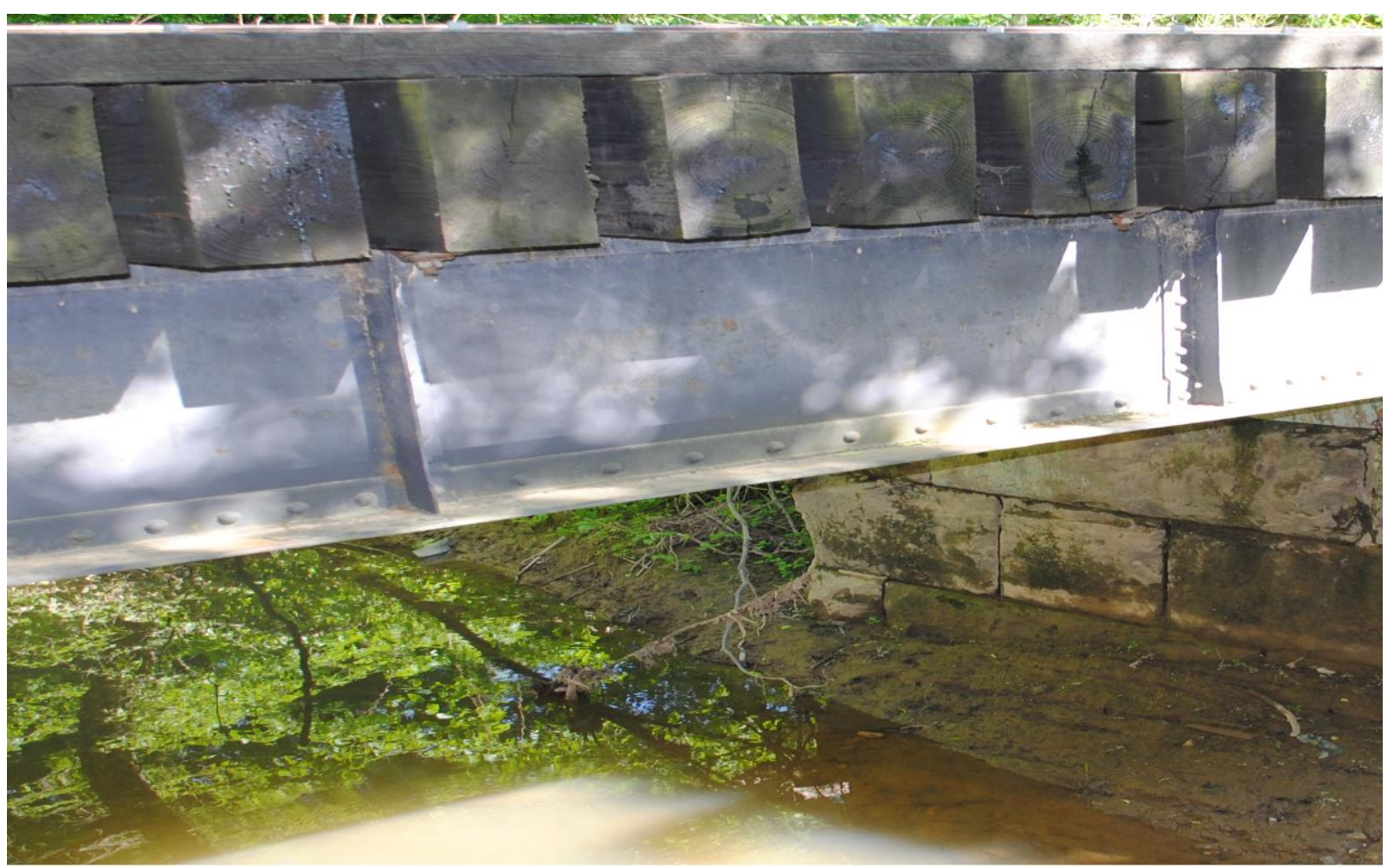

Figure F11. Minor Bank Erosion, where there is no vegetation at north abutment

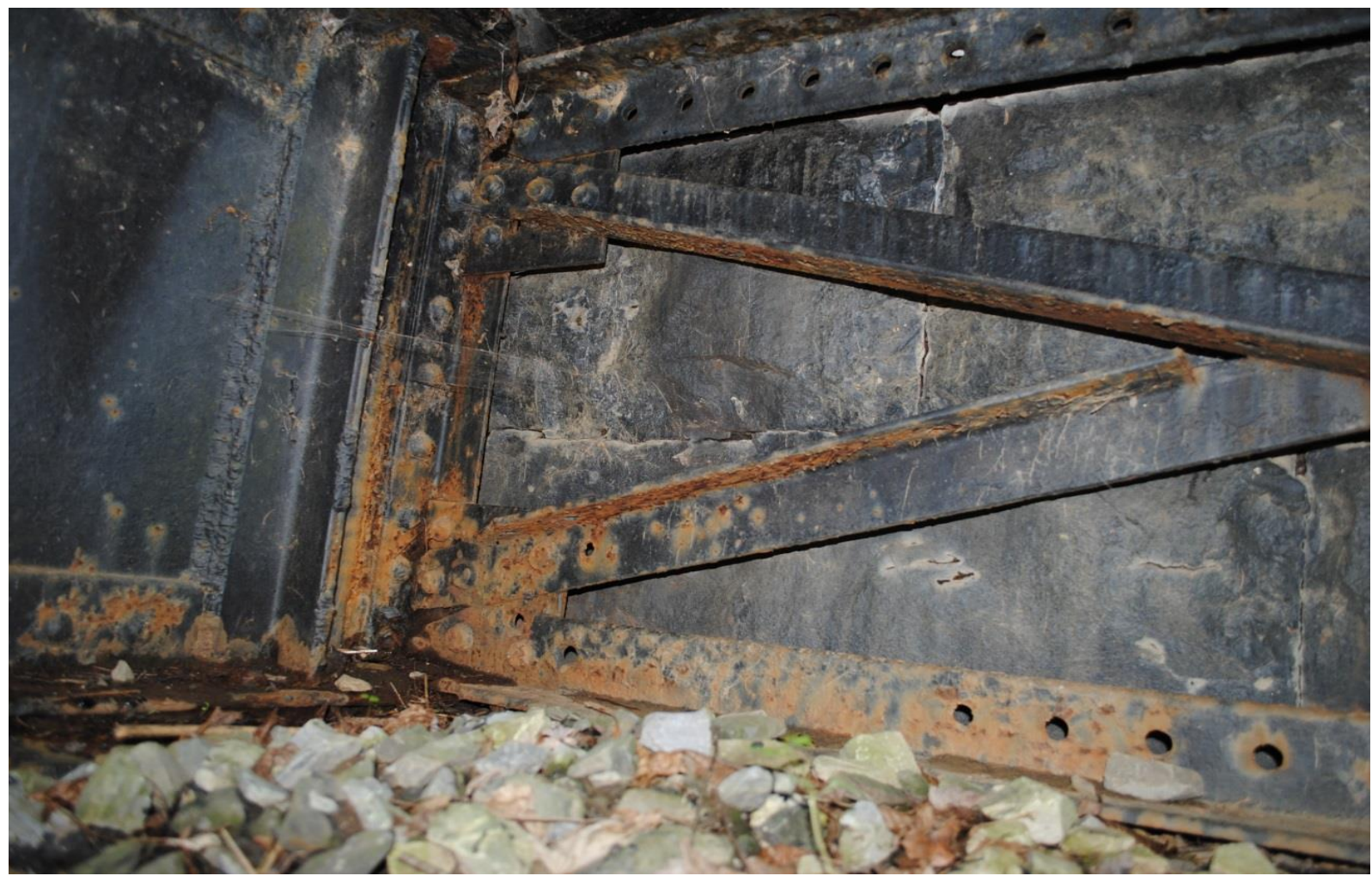

Figure F12. Ballast and Debris on North abutment, WVU-CFC Inspection, July-2014 


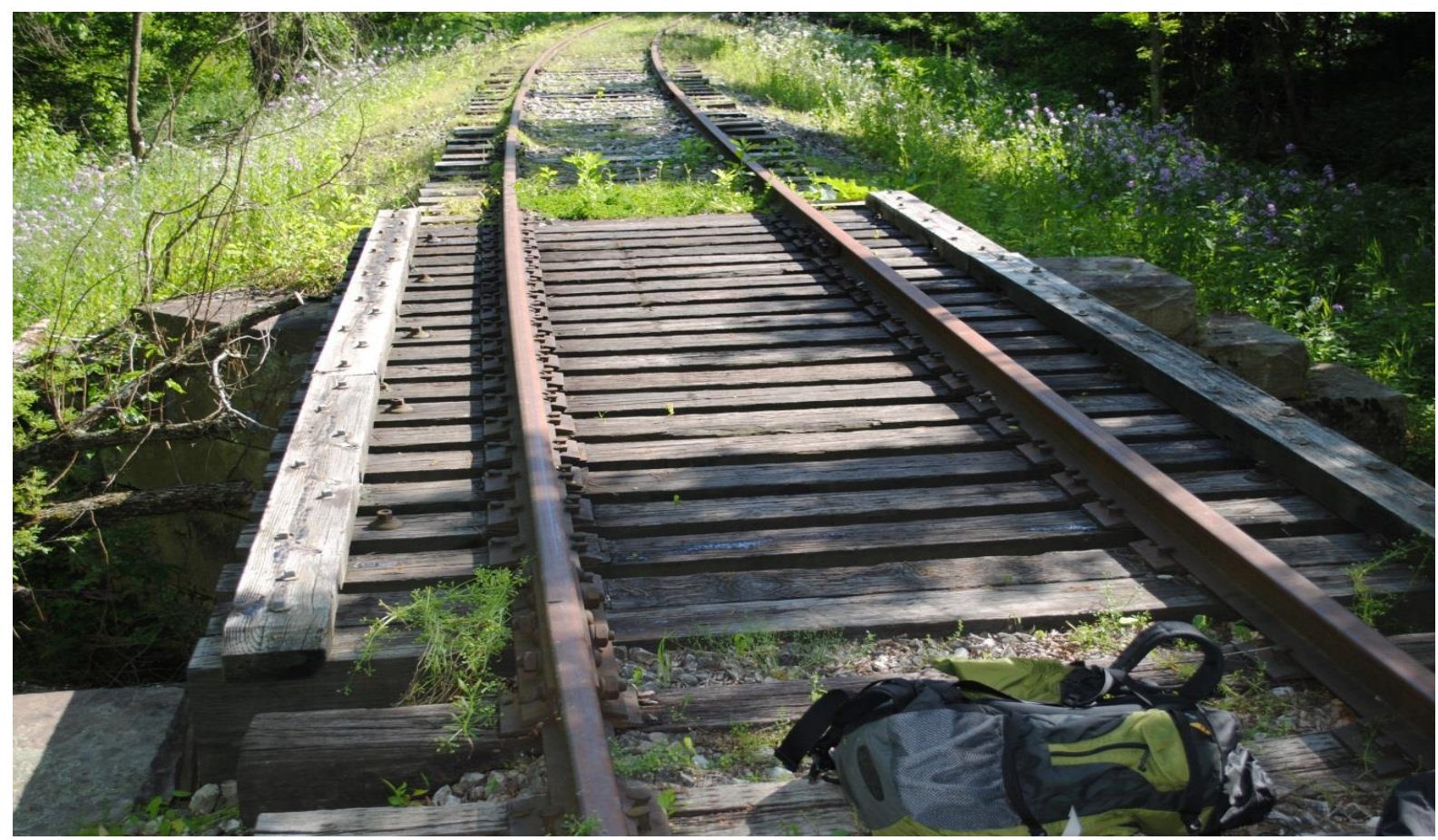

Figure F13. Bridge 5.8, Open Deck Type Bridge, WVU-CFC Inspection, July-2014

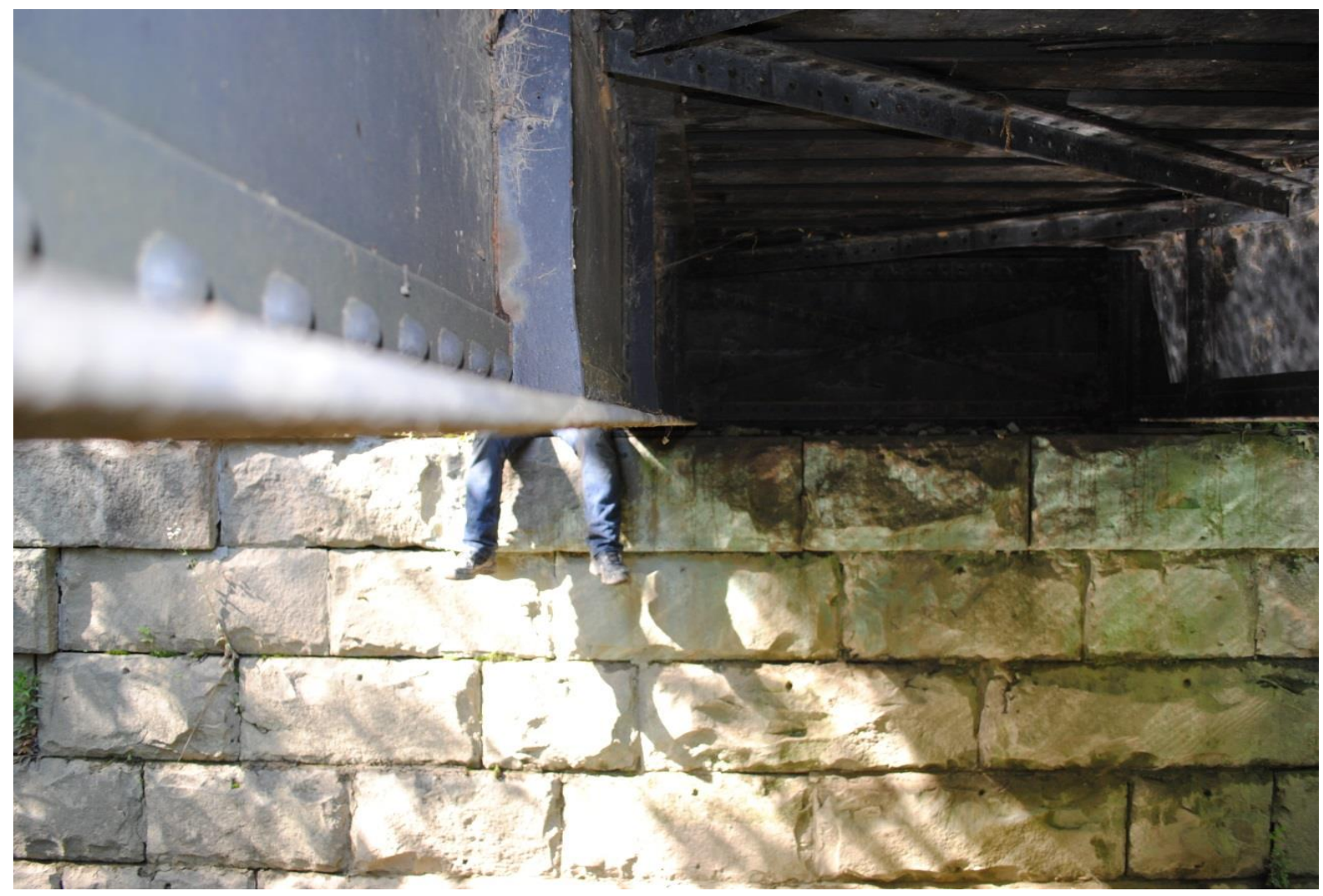

Figure F14. Masonry Abutments has Gaps between Stones, Loss of Mortar, Cap stones of north abutment are offset 2 " from lower stones 


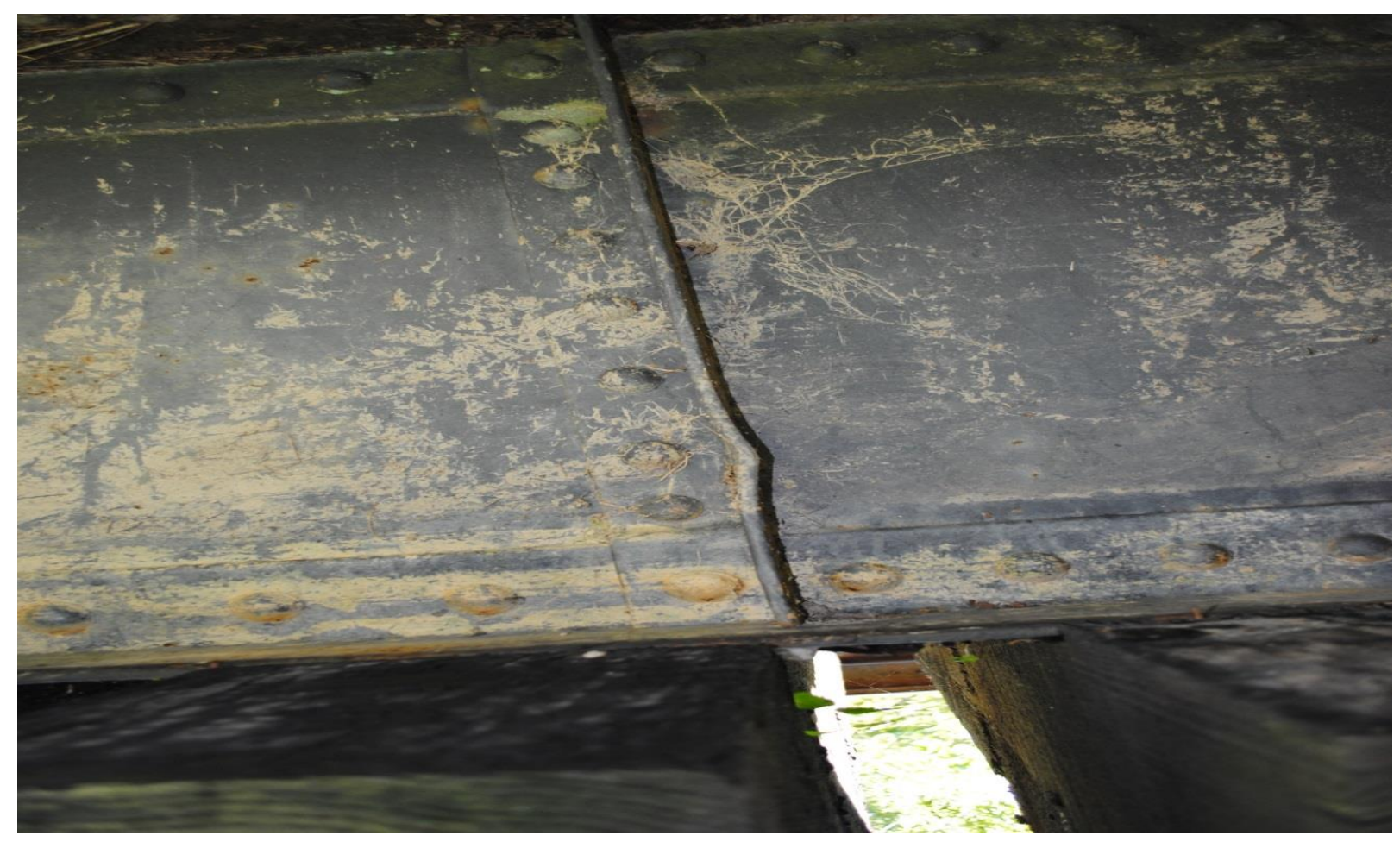

Figure F15. Girder 1, stiffener near the north abutment is bent, Minor pack rust on bottom flanges

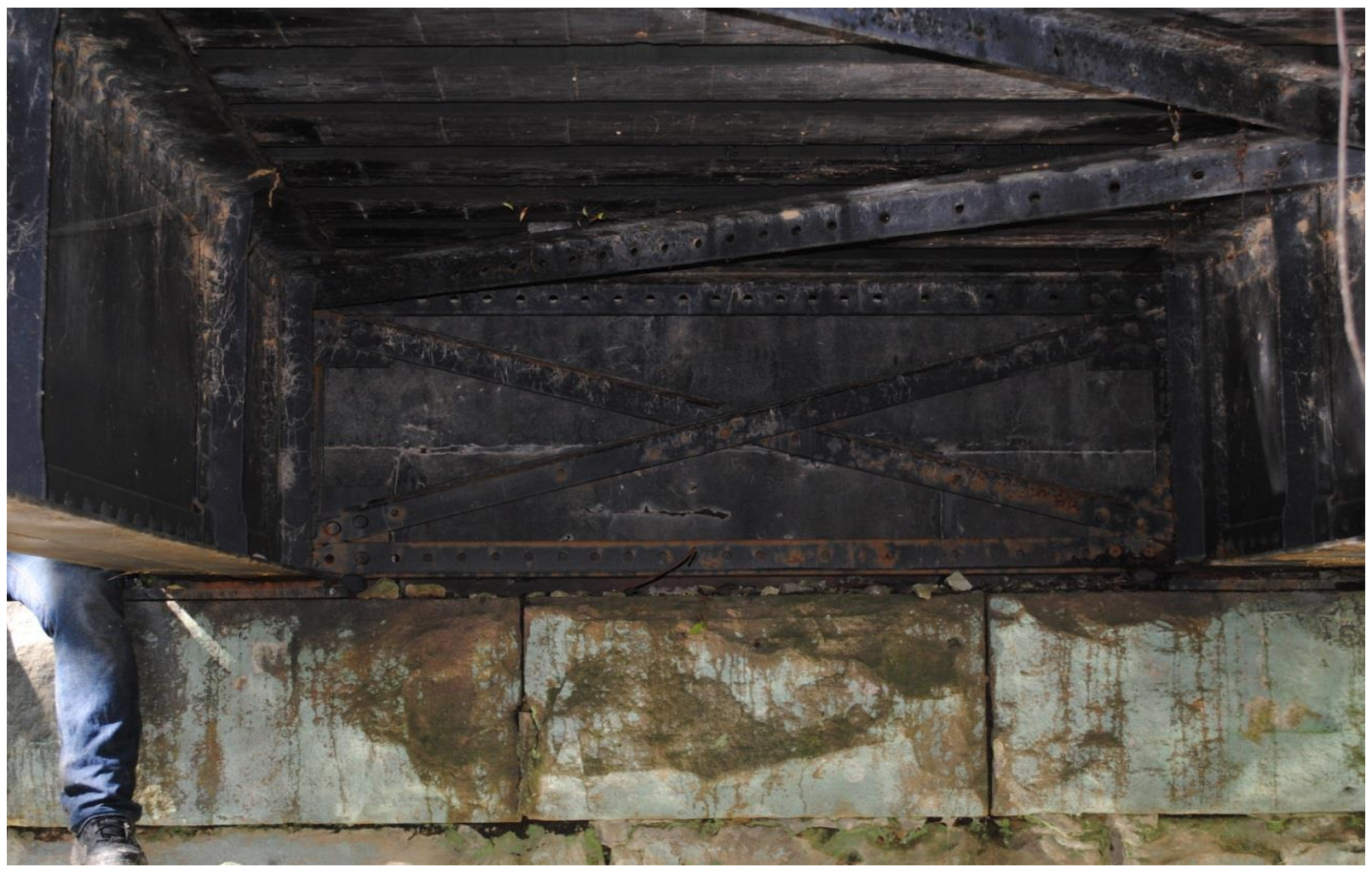

Figure F16. Minor pack rust seen at the bottom of end cross frames above north abutment, WVU-CFC Inspection, July-2014 


\section{Table 17- List of the Required geotechnical Engineering analyses for Embankments (US- DOT, 1988).}

TABLE 3

\section{REQUIRED GEOTECHNICAL ENGINEERING ANALYSIS}

\begin{tabular}{|c|c|c|c|c|c|c|c|c|}
\hline \multicolumn{3}{|c|}{ Soil Classification } & \multicolumn{2}{|c|}{ Embankment and Cut Slopes } & \multicolumn{2}{|c|}{$\begin{array}{l}\text { Structure Foundations } \\
\text { (Bridges and Retaining Structures) }\end{array}$} & \multicolumn{2}{|c|}{$\begin{array}{l}\text { Retaining Structures } \\
\text { (Conventional, Crib and MSE) }\end{array}$} \\
\hline Unified & AASHTO $^{1}$ & Soil Type & $\begin{array}{l}\text { Slope Stability } \\
\text { Analysis }\end{array}$ & $\begin{array}{l}\text { Settlement } \\
\text { Analysis }\end{array}$ & $\begin{array}{l}\text { Bearing Capacity } \\
\text { Analysis }\end{array}$ & $\begin{array}{l}\text { Settlement } \\
\text { Analysis }\end{array}$ & $\begin{array}{l}\text { Lateral Earth } \\
\text { Pressure }\end{array}$ & Stability Analysis \\
\hline $\begin{array}{l}\text { GW } \\
\text { GP } \\
\text { GM }\end{array}$ & A-1-a & $\begin{array}{l}\text { GRAVEL } \\
\text { Well-graded } \\
\text { GRAVEL } \\
\text { Poorly-graded } \\
\text { GRAVEL } \\
\text { Silty }\end{array}$ & $\begin{array}{l}\text { Generally not } \\
\text { required if cut or } \\
\text { fill slope is } 1.5 \mathrm{H} \\
\text { to } 1 \mathrm{~V} \text { or flatter, } \\
\text { and underdrains } \\
\text { are used to draw }\end{array}$ & $\begin{array}{l}\text { Generally not } \\
\text { required except } \\
\text { possibly for SC } \\
\text { soils. }\end{array}$ & $\begin{array}{l}\text { Required for } \\
\text { spread footings, } \\
\text { pile or drilled } \\
\text { shaft } \\
\text { foundations. }\end{array}$ & $\begin{array}{l}\text { Generally not } \\
\text { needed except } \\
\text { for SC soils or } \\
\text { for large, heavy } \\
\text { structures. }\end{array}$ & $\begin{array}{l}\text { GW, SP, SW \& SP } \\
\text { soils generally } \\
\text { suitable for backfill } \\
\text { behind or in } \\
\text { retaining or } \\
\text { reinforced soil }\end{array}$ & $\begin{array}{l}\text { All walls should } \\
\text { be designed to } \\
\text { provide minimum } \\
\text { F.S. = } 2 \text { against } \\
\text { overturning \& } \\
\text { F.S. = } 1.5 \text { against }\end{array}$ \\
\hline $\mathrm{GC}$ & $\begin{array}{l}\text { A-2-6 } \\
\text { A-2-7 }\end{array}$ & $\begin{array}{l}\text { GRAVEL } \\
\text { Clayey }\end{array}$ & $\begin{array}{l}\text { down the water } \\
\text { table in a cut }\end{array}$ & & $\begin{array}{l}\text { Spread footings } \\
\text { generally }\end{array}$ & $\begin{array}{l}\text { Empirical } \\
\text { correlations with }\end{array}$ & walls. & sliding along base. \\
\hline SW & $A-1-b$ & $\begin{array}{l}\text { SAND } \\
\text { Well-graded }\end{array}$ & slope. & & $\begin{array}{l}\text { adequate except } \\
\text { possibly for SC }\end{array}$ & $\begin{array}{l}\text { SPT values } \\
\text { usually used to }\end{array}$ & $\begin{array}{l}\text { GM, GC, SM \& } \\
\text { SC soils generally }\end{array}$ & \multirow{7}{*}{$\begin{array}{l}\text { External slope } \\
\text { stability } \\
\text { considerations } \\
\text { same as } \\
\text { previously given } \\
\text { for cut slopes \& } \\
\text { embankments. }\end{array}$} \\
\hline $\mathrm{SP}$ & & $\begin{array}{l}\text { SAND } \\
\text { Poorly-graded }\end{array}$ & $\begin{array}{l}\text { Erosion of slopes } \\
\text { may be a }\end{array}$ & & soils & $\begin{array}{l}\text { estimate } \\
\text { settlement }\end{array}$ & $\begin{array}{l}\text { suitable if have less } \\
\text { than } 15 \% \text { fines. }\end{array}$ & \\
\hline $\mathrm{SM}$ & $\begin{array}{l}A-2-4 \\
A-2-5\end{array}$ & $\begin{array}{l}\text { SAND } \\
\text { Silty }\end{array}$ & $\begin{array}{l}\text { problem for SW } \\
\text { or SM soils. }\end{array}$ & & & & $\begin{array}{l}\text { Lateral earth } \\
\text { pressure analysis }\end{array}$ & \\
\hline $\mathrm{SC}$ & $\begin{array}{l}\text { A-2-6 } \\
\text { A-2-7 }\end{array}$ & $\begin{array}{l}\text { SAND } \\
\text { Clayey }\end{array}$ & & & & & $\begin{array}{l}\text { required using soil } \\
\text { angle of internal } \\
\text { friction. }\end{array}$ & \\
\hline ML & A-4 & $\begin{array}{l}\text { SILT } \\
\text { Inorganic silt } \\
\text { Sandy }\end{array}$ & $\begin{array}{l}\text { Required unless } \\
\text { non-plastic. } \\
\text { Erosion of slopes } \\
\text { may be a } \\
\text { problem. }\end{array}$ & $\begin{array}{l}\text { Required unless } \\
\text { non-plastic. }\end{array}$ & $\begin{array}{l}\text { Required. } \\
\text { Spread footing } \\
\text { generally } \\
\text { adequate. }\end{array}$ & $\begin{array}{l}\text { Required. } \\
\text { Can use SPT } \\
\text { values if non- } \\
\text { plastic. }\end{array}$ & \multirow[t]{3}{*}{$\begin{array}{l}\text { These soils are not } \\
\text { recommended for } \\
\text { use directly behind } \\
\text { or in retaining or } \\
\text { reinforced soil } \\
\text { walls. }\end{array}$} & \\
\hline $\mathrm{CL}$ & A-6 & $\begin{array}{l}\text { CLAY } \\
\text { Inorganic } \\
\text { Lean Clay }\end{array}$ & Required & Required & & & & \\
\hline $\mathrm{OL}$ & A-4 & $\begin{array}{l}\text { SILT } \\
\text { Organic }\end{array}$ & Required & Required & & & & \\
\hline
\end{tabular}

\footnotetext{
${ }^{1}$ This is an approximate correlation to Unified (Unified Soil Classification system is preferred for geotechnical engineering usage, AASHTO system was developed for rating pavement subgrades).

${ }^{2}$ These are general guidelines, detailed slope stability analysis may not be required where past experience in area is similar or rock gives required slope angles.
}

Table 22. is continued in the next page 
TABLE 3 (Continued)

\begin{tabular}{|c|c|c|c|c|c|c|c|c|}
\hline \multicolumn{3}{|c|}{ Soil Classification } & \multicolumn{2}{|c|}{ Embankment and Cut Slopes } & \multicolumn{2}{|c|}{$\begin{array}{l}\text { Structure Foundations } \\
\text { (Bridges and Retaining Structures) }\end{array}$} & \multicolumn{2}{|c|}{$\begin{array}{l}\text { Retaining Structures } \\
\text { (Conventional, Crib and MSE) }\end{array}$} \\
\hline Unified & AASHTO $^{1}$ & Soil Type & $\begin{array}{l}\text { Slope Stability } \\
\text { Analysis }\end{array}$ & $\begin{array}{l}\text { Settlement } \\
\text { Analysis }\end{array}$ & $\begin{array}{l}\text { Bearing Capacity } \\
\text { Analysis }\end{array}$ & $\begin{array}{l}\text { Settlement } \\
\text { Analysis }\end{array}$ & $\begin{array}{l}\text { Lateral Earth } \\
\text { Pressure }\end{array}$ & Stability Analysis \\
\hline $\mathrm{MH}$ & A-5 & $\begin{array}{l}\text { SILT } \\
\text { Inorganic }\end{array}$ & $\begin{array}{l}\text { Required. } \\
\text { Erosion of slopes } \\
\text { may be a } \\
\text { problem. }\end{array}$ & Required. & \multirow{3}{*}{$\begin{array}{l}\text { Required. } \\
\text { Deep foundation } \\
\text { generally } \\
\text { required unless } \\
\text { soil has been } \\
\text { preloaded. }\end{array}$} & \multirow{3}{*}{$\begin{array}{l}\text { Required. } \\
\text { Consolidation } \\
\text { test data needed } \\
\text { to estimate } \\
\text { settlement } \\
\text { amount and time. }\end{array}$} & $\begin{array}{l}\text { These soils are not } \\
\text { recommended for } \\
\text { use directly behind } \\
\text { or in retaining }\end{array}$ & \multirow{5}{*}{$\begin{array}{l}\text { All walls should } \\
\text { be designed to } \\
\text { provide minimum } \\
\text { F.S. = } 2 \text { against } \\
\text { overturning \& } \\
\text { F.S. = } 1.5 \text { against } \\
\text { sliding along base. } \\
\text { External slope } \\
\text { stability } \\
\text { considerations } \\
\text { same as } \\
\text { previously given } \\
\text { for cut slopes \& } \\
\text { embankments }\end{array}$} \\
\hline $\mathrm{CH}$ & A-7 & $\begin{array}{l}\text { CLAY } \\
\text { Inorganic } \\
\text { Fat Clay }\end{array}$ & Required. & Required. & & & walls. & \\
\hline $\mathrm{OH}$ & A-7 & $\begin{array}{l}\text { CLAY } \\
\text { Organic }\end{array}$ & Required. & Required. & & & & \\
\hline PT & 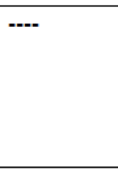 & $\begin{array}{l}\text { PEAT } \\
\text { Muck }\end{array}$ & Required. & $\begin{array}{l}\text { Required. } \\
\text { Long term } \\
\text { settlement can be } \\
\text { significant }\end{array}$ & $\begin{array}{l}\text { Deep foundation } \\
\text { required unless } \\
\text { peat excavated } \\
\text { and replaced. }\end{array}$ & $\begin{array}{l}\text { Highly } \\
\text { compressible and } \\
\text { not suitable for } \\
\text { foundation } \\
\text { support }\end{array}$ & & \\
\hline Rock & & & \multicolumn{2}{|c|}{$\begin{array}{l}\text { Fills - not required for slopes } 1.5 \mathrm{H} \text { to } \\
1 \mathrm{~V} \text { or flatter. } \\
\text { Cuts - required but depends on } \\
\text { spacing, orientation and strength of } \\
\text { discontinuities and durability of rock }\end{array}$} & $\begin{array}{l}\text { Required for } \\
\text { spread footings } \\
\text { or drilled shafts. } \\
\text { Empirically } \\
\text { related to RQD } \\
3\end{array}$ & $\begin{array}{l}\text { Required where } \\
\text { rock is badly } \\
\text { weathered or } \\
\text { closely fractured } \\
\text { (low RQD). } \\
\text { May require in } \\
\text { situ test such as } \\
\text { pressuremeter. }\end{array}$ & $\begin{array}{l}\text { Required. } \\
\text { Use rock backfill } \\
\text { angle of internal } \\
\text { friction. }\end{array}$ & \\
\hline \multicolumn{9}{|c|}{$\begin{array}{l}\text { REMARKS: } \\
\text { Soils - temporary ground water control may be needed for foundation excavations in GW through SM soils. } \\
\text { Backfill specifications for reinforced soil walls using metal reinforcements should meet the following requirements in insure use of non-corrosive backfill: } \\
\text { pH range = } 5 \text { to } 10 \text {; Resistivity }>3000 \mathrm{ohm}-\mathrm{cm} \text {; Chlorides }<100 \mathrm{ppm} \text {; Sulfates }<200 \mathrm{ppm} \text {; Organic content } 1 \% \text { maximum }\end{array}$} \\
\hline
\end{tabular}

${ }^{1}$ This is an approximate correlation to Unified (Unified Soil Classification system is preferred for geotechnical engineering usage, AASHTO system was developed for rating pavement subgrades).

${ }^{2}$ These are general guidelines, detailed slope stability analysis may not be required where past experience in area is similar or rock gives required slope angles.

${ }^{3} \mathrm{RQD}$ (Rock Quality Designation) = sum of pieces of rock core 4" or greater in length divided by the total length of core run. 